\title{
Toe structure stability of rubble mound breakwaters
}

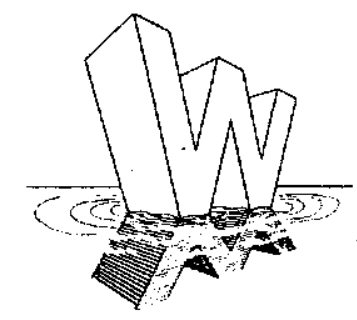




\section{List of tables}

1. Overall view of tests performed

2. Original test results from the present tests

3. Present data with constant damage levels $\mathbf{N}_{\text {od }}$

4. Data from existing test reports 


\section{Abstract}

In this report an analysis of data from a series of tests is presented on the stability of the toe structure of rubble mound breakwaters.

The existing knowledge on toe stability and the influence of all governing parameters in the existing knowledge is reviewed.

The tests which were performed for the present research are treated extensively.

The main governing parameters, which determine toe stability in rubble mound breakwaters, are:

$\begin{array}{lll}\text { significant wave height } & \mathrm{H}_{\mathrm{s}} \\ \text { nominal stone diameter } & : & \mathrm{D}_{\mathrm{n} 50} \\ \text { stone mass density } & : & \rho_{\mathrm{s}} \\ \text { depth above the toe } & : & \mathrm{h}_{\mathrm{t}} \\ \text { damage level } & : & \mathrm{N}_{\mathrm{od}}\end{array}$

Parameters investigated which appeared to have no significant influence are: the fictitious wave steepness $s_{o p}$ and the width of the toe structure $b_{t}$.

The choice of the governing parameters, the definition of damage levels for the design of the toe structure and the way they are made dimensionless are motivated.

The results from the present tests are compared with existing design formula.

With the selected parameters two formulas have been derived from the available test data. One describes toe stability using the shallow water significant wave height $\mathrm{H}_{s}$ the other uses the shallow water $2 \%$ wave height $\mathrm{H}_{2 \%}$.

The formulas are compared with existing test results and their range of application is given. 


\title{
CONTENTS
}

\author{
List of tables
}

List of figures

Notation

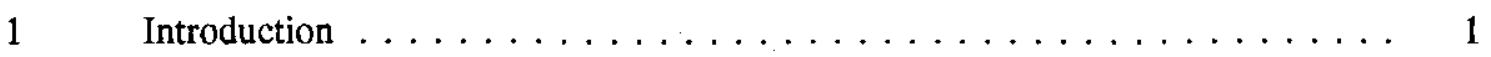

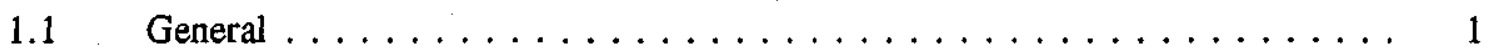

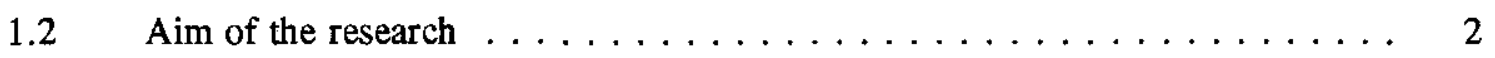

1.3 Conclusions and recommendations $\ldots \ldots \ldots \ldots \ldots \ldots$

2 Overview of existing knowledge $\ldots \ldots \ldots \ldots \ldots \ldots$

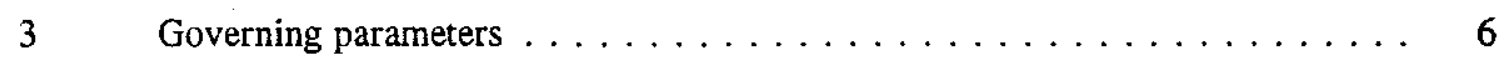

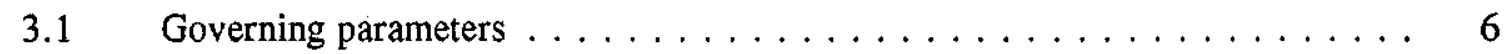

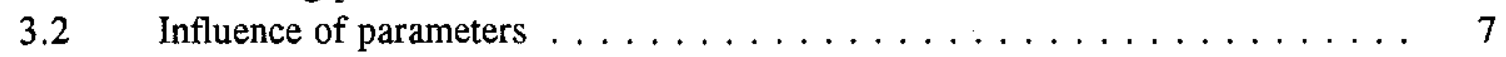

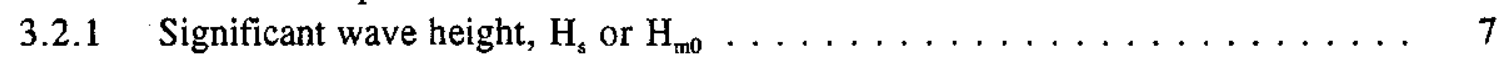

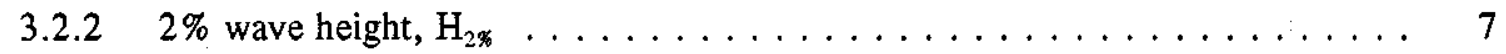

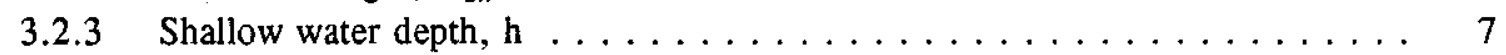

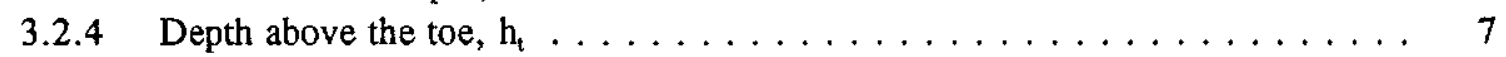

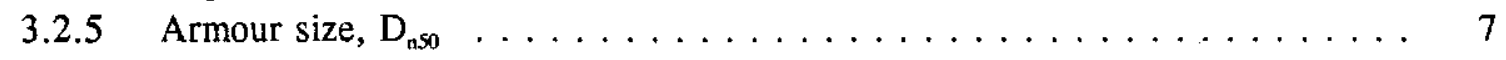

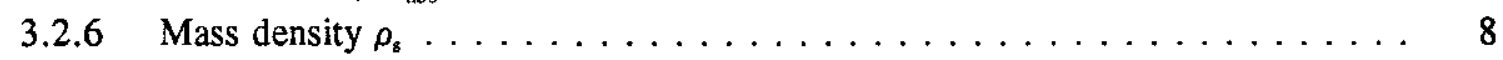

3.2.7 Peak wave period, $\mathrm{T}_{\mathrm{p}}$ or wave steepness, $\mathrm{s}_{\mathrm{op}} \ldots \ldots \ldots \ldots \ldots \ldots \ldots$

3.2.8 Width of the toe structure, $b_{t} \ldots \ldots \ldots \ldots \ldots$

$4 \quad$ Description of laboratory tests $\ldots \ldots \ldots \ldots \ldots \ldots$

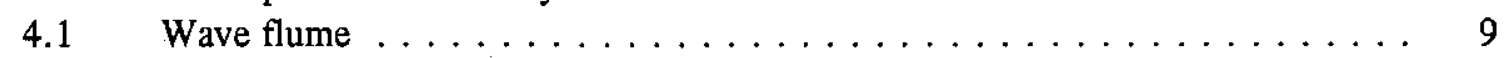

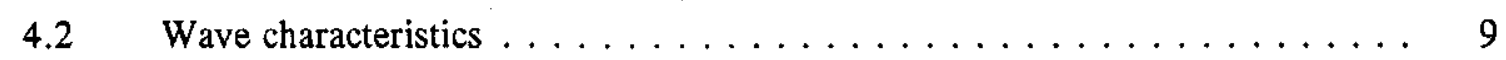

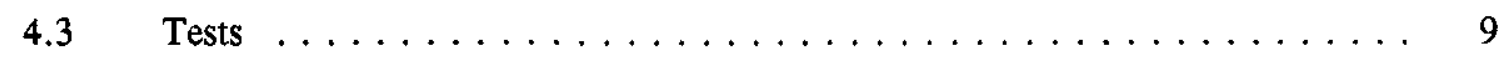

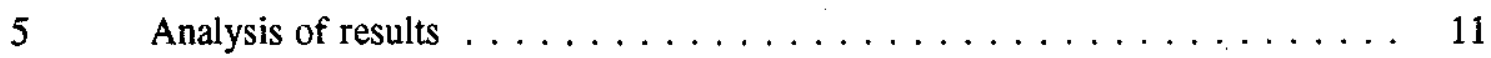

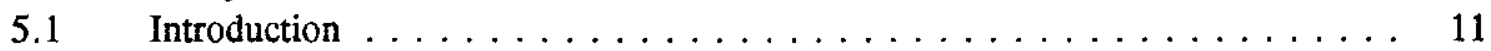

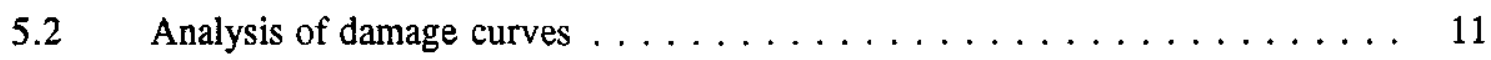

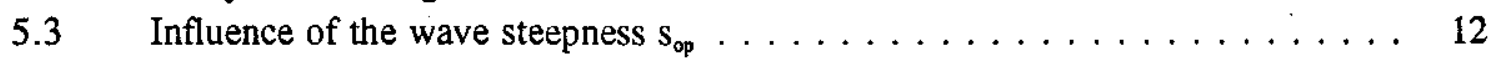

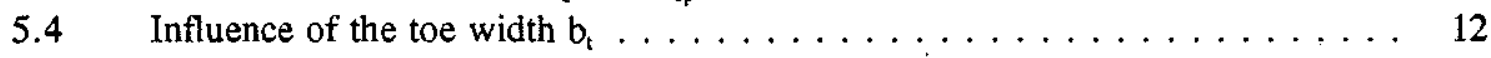

5.5 Influence of the shallow water depth $h_{m} \ldots \ldots \ldots \ldots 13$

5.6 Influence of the toe height $h_{m}-h_{t}$ or the depth above toe $h_{t} \ldots \ldots \ldots 13$

5.7 Influence of the stone diameter $D_{\text {nso }} \ldots \ldots \ldots \ldots \ldots$

6 Relation with the damage level $\mathrm{N}_{\mathrm{od}} \ldots \ldots \ldots \ldots \ldots \ldots \ldots$

6.1 Analysis ......................... 15

7 Quantitative analysis with the stability number $\mathrm{H}_{s} / \Delta \mathrm{D}_{\mathrm{n} s \mathrm{~s}} \ldots \ldots \ldots \ldots$

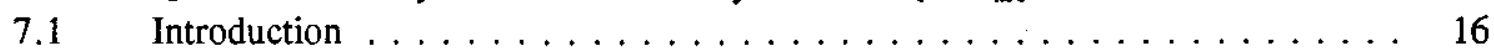

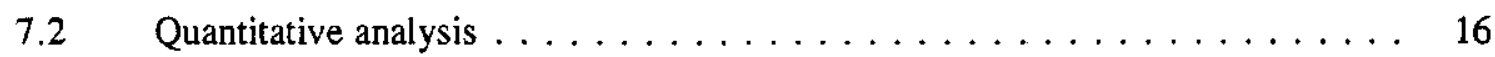

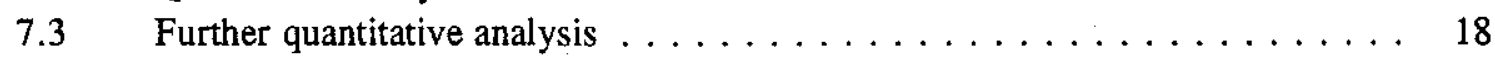




\section{Contents (continued)}

8 Comparison of the relation from the present study with existing test results . . 21

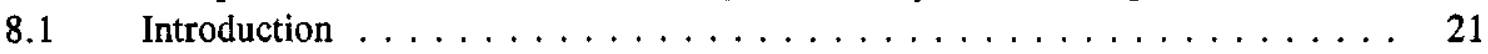

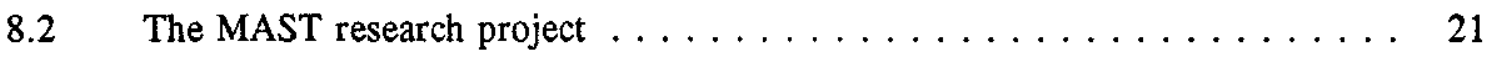

8.3 Comparison of the result of the present study with existing test results . . . . 22

$9 \quad$ Discarded parameters $\ldots \ldots \ldots \ldots \ldots \ldots \ldots \ldots \ldots \ldots$

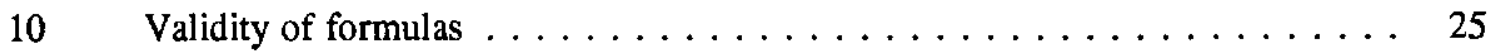

References

Tables

Figures 


\section{List of figures}

1. Example of breakwater cross section

2. Proposed design curve for toe stability by van der Meer (CUR, 1991)

3. Governing parameters for toe stability

4. Overview of test set-up

5. Breakwater cross section of test set-up

6a. Influence of water depth on significant wave height for $\mathrm{s}_{\mathrm{op}}=0.02$

6b. Influence of water depth on significant wave height for $s_{\mathrm{op}}=0.04$

7a. Influence of water depth on $2 \%$ wave height for $\mathrm{s}_{\mathrm{op}}=0.02$

7b. Influence of water depth on $2 \%$ wave height for $s_{o p}=0.04$

8. Excedance curves and energy density spectra for $h=0.7 \mathrm{~m}$

9. Excedance curves and energy density spectra for $h=0.8 \mathrm{~m}$

10. Excedance curves and energy density spectra for $h=0.9 \mathrm{~m}$

11. $\mathrm{H}_{2 \%} / \mathrm{H}_{\mathrm{s}}$ as a function of the relative water depth $\mathrm{h}_{\mathrm{m}} / \mathrm{H}_{\mathrm{s}}$

12a. Damage level $\mathrm{N}_{o d}$ as a function of the significant wave height $\mathrm{H}_{s}$ for fixed stone diameters $\mathrm{D}_{\mathrm{n} 50}$ and $\mathrm{s}_{\mathrm{op}}=0.02, \mathrm{~h}=0.7 \mathrm{~m}, \mathrm{~h}_{\mathrm{m}}-\mathrm{h}_{\mathrm{t}}=0.08 \mathrm{~m}$ and $\mathrm{b}_{\mathrm{t}}=0.12 \mathrm{~m}$

12b. Damage level $\mathbf{N}_{o d}$ as a function of the significant wave height $\mathbf{H}_{s}$ for fixed stone diameters $\mathrm{D}_{\mathrm{n} 50}$ and $\mathrm{s}_{\mathrm{op}}=0.04, \mathrm{~h}=0.7 \mathrm{~m}, \mathrm{~h}_{\mathrm{m}}-\mathrm{h}_{\mathrm{t}}=0.08 \mathrm{~m}$ and $\mathrm{b}_{\mathrm{t}}=0.12 \mathrm{~m}$

13a. Damage level $\mathrm{N}_{o d}$ as a function of the significant wave height $\mathrm{H}_{s}$ for fixed stone diameters $D_{n 50}$ and $s_{o p}=0.02, h=0.8 m, h_{n}-h_{t}=0.08 m$ and $b_{t}=0.12 m$

13b. Damage level $\mathrm{N}_{o d}$ as a function of the significant wave height $\mathrm{H}_{s}$ for fixed stone diameters $D_{n 50}$ and $s_{o p}=0.04, h=0.8 m, h_{m}-h_{t}=0.08 m$ and $b_{t}=0.12 m$

14. Damage level $\mathrm{N}_{o d}$ as a function of the significant wave height $\mathrm{H}_{\mathrm{s}}$ for fixed stone diameters $D_{n s 0}$ and $s_{o p}=0.04, h=0.7 m, h_{m}-h_{t}=0.15 m$ and $b_{t}=0.12 m$

15a. Damage level $\mathrm{N}_{\text {od }}$ as a function of the significant wave height $\mathrm{H}_{3}$ for fixed stone diameters $\mathrm{D}_{\mathrm{n} 50}$ and $\mathrm{s}_{\mathrm{op}}=0.02, \mathrm{~h}=0.9 \mathrm{~m}, \mathrm{~h}_{\mathrm{m}}-\mathrm{h}_{\mathrm{t}}=0.08 \mathrm{~m}$ and $\mathrm{b}_{\mathrm{t}}=0.12 \mathrm{~m}$

15b. Damage level $\mathrm{N}_{o d}$ as a function of the significant wave height $\mathrm{H}_{\mathrm{s}}$ for fixed stone diameters $D_{n 50}$ and $s_{o p}=0.04, h=0.9 m, h_{m}-h_{t}=0.08 m$ and $b_{t}=0.12 m$ 


\section{List of figures (continued)}

16a. Damage level $\mathrm{N}_{\mathrm{od}}$ as a function of the significant wave height $\mathrm{H}_{\mathrm{s}}$ for fixed stone diameters $\mathrm{D}_{\mathrm{n} 50}$ and $\mathrm{s}_{\mathrm{op}}=0.02, \mathrm{~h}=0.7 \mathrm{~m}, \mathrm{~h}_{\mathrm{m}}-\mathrm{h}_{\mathrm{t}}=0.15 \mathrm{~m}$ and $\mathrm{b}_{\mathrm{t}}=0.12 \mathrm{~m}$

16b. Damage level $\mathrm{N}_{o d}$ as a function of the significant wave height $\mathrm{H}_{s}$ for fixed stone diameters $\mathrm{D}_{\mathrm{n} 50}$ and $\mathrm{s}_{\mathrm{op}}=0.04, \mathrm{~h}=0.7 \mathrm{~m}, \mathrm{~h}_{\mathrm{n}}-\mathrm{h}_{\mathrm{t}}=0.15 \mathrm{~m}$ and $\mathrm{b}_{\mathrm{t}}=0.12 \mathrm{~m}$

17a. Damage level $\mathrm{N}_{\mathrm{od}}$ as a function of the significant wave height $\mathrm{H}_{\mathrm{s}}$ for fixed stone diameters $D_{n 50}$ and $s_{o p}=0.02, h=0.8 m, h_{m}-h_{t}=0.15 m$ and $b_{t}=0.12 m$

17b. Damage level $\mathrm{N}_{\mathrm{od}}$ as a function of the significant wave height $\mathrm{H}_{s}$ for fixed stone diameters $\mathrm{D}_{\mathrm{n} 50}$ and $\mathrm{s}_{\mathrm{op}}=0.04, \mathrm{~h}=0.8 \mathrm{~m}, \mathrm{~h}_{\mathrm{m}}-\mathrm{h}_{\mathrm{t}}=0.15 \mathrm{~m}$ and $\mathrm{b}_{\mathrm{t}}=0.12 \mathrm{~m}$

18a. Damage level $\mathrm{N}_{o d}$ as a function of the significant wave height $\mathrm{H}_{s}$ for fixed stone diameters $\mathrm{D}_{\mathrm{n} 50}$ and $\mathrm{s}_{\mathrm{op}}=0.02, \mathrm{~h}=0.9 \mathrm{~m}, \mathrm{~h}_{\mathrm{m}}-\mathrm{h}_{\mathrm{t}}=0.15 \mathrm{~m}$ and $\mathrm{b}_{\mathrm{t}}=0.12 \mathrm{~m}$

18b. Damage level $\mathrm{N}_{\mathrm{od}}$ as a function of the significant wave height $\mathrm{H}_{s}$ for fixed stone diameters $\mathrm{D}_{\mathrm{n} 50}$ and $\mathrm{s}_{\mathrm{op}}=0.04, \mathrm{~h}=0.9 \mathrm{~m}, \mathrm{~h}_{\mathrm{m}}-\mathrm{h}_{\mathrm{t}}=0.15 \mathrm{~m}$ and $\mathrm{b}_{\mathrm{t}}=0.12 \mathrm{~m}$

19a. Damage level $\mathrm{N}_{\mathrm{od}}$ as a function of the significant wave height $\mathbf{H}_{s}$ for fixed stone diameters $\mathrm{D}_{\mathrm{n} 50}$ and $\mathrm{s}_{\mathrm{op}}=0.02, \mathrm{~h}=0.8 \mathrm{~m}, \mathrm{~h}_{\mathrm{m}}-\mathrm{h}_{\mathrm{t}}=0.22 \mathrm{~m}$ and $\mathrm{b}_{\mathrm{t}}=0.12 \mathrm{~m}$

19b. Damage level $\mathrm{N}_{\mathrm{od}}$ as a function of the significant wave height $\mathrm{H}_{s}$ for fixed stone diameters $D_{n 50}$ and $s_{0 p}=0.04, h=0.8 m, h_{m}-h_{t}=0.22 m$ and $b_{t}=0.12 m$

20a. Damage level $\mathrm{N}_{o d}$ as a function of the significant wave height $\mathrm{H}_{\mathrm{s}}$ for fixed stone diameters $D_{n s 0}$ and $s_{o p}=0.02, h=0.9 m, h_{m}-h_{t}=0.22 m$ and $b_{t}=0.12 m$

20b. Damage level $\mathrm{N}_{\mathrm{od}}$ as a function of the significant wave height $\mathrm{H}_{\mathrm{s}}$ for fixed stone diameters $D_{n 50}$ and $s_{o p}=0.04, h=0.9 m, h_{m}-h_{t}=0.22 m$ and $b_{t}=0.12 m$

21a. Damage level $\mathrm{N}_{\mathrm{od}}$ as a function of the significant wave height $\mathrm{H}_{s}$ for fixed stone diameters $\mathrm{D}_{\mathrm{n} 50}$ and $\mathrm{s}_{\mathrm{op}}=0.02, \mathrm{~h}=0.9 \mathrm{~m}, \mathrm{~h}_{\mathrm{m}}-\mathrm{h}_{\mathrm{t}}=0.15 \mathrm{~m}$ and $\mathrm{b}_{\mathrm{t}}=0.20 \mathrm{~m}$

21b. Damage level $\mathrm{N}_{o d}$ as a function of the significant wave height $\mathrm{H}_{\mathrm{s}}$ for fixed stone diameters $D_{n 50}$ and $s_{o p}=0.04, h=0.9 m, h_{m}-h_{t}=0.15 m$ and $b_{t}=0.20 m$

22a. Damage level $\mathrm{N}_{o d}$ as a function of the significant wave height $\mathrm{H}_{s}$ for fixed stone diameters $D_{n 50}$ and $s_{o p}=0.02, h=0.9 m, h_{m}-h_{t}=0.15 m$ and $b_{t}=0.30 m$

22b. Damage level $\mathrm{N}_{o d}$ as a function of the significant wave height $\mathrm{H}_{s}$ for fixed stone diameters $\mathrm{D}_{\mathrm{n} 50}$ and $\mathrm{s}_{\mathrm{op}}=0.04, \mathrm{~h}=0.9 \mathrm{~m}, \mathrm{~h}_{\mathrm{m}}-\mathrm{h}_{\mathrm{t}}=0.15 \mathrm{~m}$ and $\mathrm{b}_{\mathrm{t}}=0.30 \mathrm{~m}$

23a. Significant wave height $H_{s}$ as a function of the fictitious wave steepness $s_{\text {op }}$ for fixed damage levels $\mathrm{N}_{o d}$ for $\mathrm{h}=0.7 \mathrm{~m}, \mathrm{~h}_{m}-\mathrm{h}_{\mathrm{t}}=0.08 \mathrm{~m}, \mathrm{~b}_{\mathrm{t}}=0.12 \mathrm{~m}$ and $\mathrm{D}_{\mathrm{n} 50}=0.017 \mathrm{~m}$

23b. Significant wave height $\mathrm{H}_{\mathrm{s}}$ as a function of the fictitious wave steepness $\mathrm{s}_{\mathrm{op}}$ for fixed damage levels $\mathrm{N}_{\mathrm{od}}$ for $\mathrm{h}=0.7 \mathrm{~m}, \mathrm{~h}_{\mathrm{m}}-\mathrm{h}_{\mathrm{t}}=0.08 \mathrm{~m}, \mathrm{~b}_{\mathrm{t}}=0.12 \mathrm{~m}$ and $\mathrm{D}_{\mathrm{n} 50}=0.035 \mathrm{~m}$ 


\section{List of figures (continued)}

24a. Significant wave height $H_{s}$ as a function of the fictitious wave steepness $s_{\text {op }}$ for fixed damage levels $\mathrm{N}_{\mathrm{od}}$ for $\mathrm{h}=0.9 \mathrm{~m}, \mathrm{~h}_{\mathrm{m}}-\mathrm{h}_{\mathrm{t}}=0.15 \mathrm{~m}, \mathrm{~b}_{\mathrm{t}}=0.12 \mathrm{~m}$ and $\mathrm{D}_{\mathrm{n} 50}=0.025 \mathrm{~m}$

24b. Significant wave height $H_{s}$ as a function of the fictitious wave steepness $s_{o p}$ for fixed damage levels $\mathrm{N}_{o d}$ for $\mathrm{h}=0.8 \mathrm{~m}, \mathrm{~h}_{\mathrm{m}}-\mathrm{h}_{\mathrm{t}}=0.22 \mathrm{~m}, \mathrm{~b}_{\mathrm{t}}=0.12 \mathrm{~m}$ and $\mathrm{D}_{\mathrm{n} 50}=0.025 \mathrm{~m}$

25a. Significant wave height $H_{s}$ as a function of the fictitious wave steepness $s_{o p}$ for fixed damage levels $\mathrm{N}_{\mathrm{od}}$ for $\mathrm{h}=0.9 \mathrm{~m}, \mathrm{~h}_{\mathrm{m}}-\mathrm{h}_{\mathrm{t}}=0.22 \mathrm{~m}, \mathrm{~b}_{\mathrm{t}}=0.12 \mathrm{~m}$ and $\mathrm{D}_{\mathrm{n} 50}=0.025 \mathrm{~m}$

25b. Significant wave height $\mathrm{H}_{\mathrm{s}}$ as a function of the fictitious wave steepness $s_{\mathrm{op}}$ for fixed damage levels $\mathrm{N}_{\text {od }}$ for $\mathrm{h}=0.9 \mathrm{~m}, \mathrm{~h}_{\mathrm{m}}-\mathrm{h}_{\mathrm{t}}=0.15 \mathrm{~m}, \mathrm{~b}_{\mathrm{t}}=0.20 \mathrm{~m}$ and $\mathrm{D}_{\mathrm{n} 50}=0.025 \mathrm{~m}$

26a. Significant wave height $\mathrm{H}_{\mathrm{s}}$ as a function of the fictitious wave steepness $s_{\text {op }}$ for fixed damage levels $\mathrm{N}_{\mathrm{od}}$ for $\mathrm{h}=0.9 \mathrm{~m}, \mathrm{~h}_{\mathrm{m}}-\mathrm{h}_{\mathrm{t}}=0.15 \mathrm{~m}, \mathrm{~b}_{\mathrm{t}}=0.20 \mathrm{~m}$ and $\mathrm{D}_{\mathrm{n} 50}=0.040 \mathrm{~m}$

26b. Significant wave height $\mathrm{H}_{\mathrm{s}}$ as a function of the fictitious wave steepness $s_{\mathrm{op}}$ for fixed damage levels $\mathrm{N}_{\mathrm{od}}$ for $\mathrm{h}=0.9 \mathrm{~m}, \mathrm{~h}_{\mathrm{m}}-\mathrm{h}_{\mathrm{t}}=0.15 \mathrm{~m}, \mathrm{~b}_{\mathrm{t}}=0.30 \mathrm{~m}$ and $\mathrm{D}_{\mathrm{n} 50}=0.025 \mathrm{~m}$

27a. Damage level $\mathrm{N}_{\mathrm{od}}$ as a function of the significant wave height $\mathrm{H}_{\mathrm{s}}$ for fixed wave steepness $\mathrm{s}_{\mathrm{op}}$ for $\mathrm{h}=0.7 \mathrm{~m}, \mathrm{~h}_{\mathrm{m}}-\mathrm{h}_{\mathrm{t}}=0.08 \mathrm{~m}, \mathrm{~b}_{\mathrm{t}}=0.12 \mathrm{~m}, \mathrm{D}_{\mathrm{n} 50}=0.017 \mathrm{~m}$

27b. Damage level $\mathrm{N}_{\text {od }}$ as a function of the significant wave height $H_{s}$ for fixed wave steepness $\mathrm{s}_{\text {op }}$ for $\mathrm{h}=0.7 \mathrm{~m}, \mathrm{~h}_{\mathrm{m}}-\mathrm{h}_{\mathrm{t}}=0.08 \mathrm{~m}, \mathrm{~b}_{\mathrm{t}}=0.12 \mathrm{~m}, \mathrm{D}_{\mathrm{n} 50}=0.035 \mathrm{~m}$

28a. Damage level $\mathbf{N}_{o d}$ as a function of the significant wave height $\mathbf{H}_{s}$ for fixed wave steepness $s_{\text {op }}$ for $h=0.7 \mathrm{~m}, h_{m}-h_{t}=0.15 \mathrm{~m}, b_{t}=0.12 \mathrm{~m}, D_{n 50}=0.040 \mathrm{~m}$

28b. Damage level $N_{o d}$ as a function of the significant wave height $H_{s}$ for fixed wave steepness $s_{\text {op }}$ for $h=0.9 \mathrm{~m}, h_{m}-h_{t}=0.08 m, b_{t}=0.12 m, D_{n 50}=0.017 m$

29. Significant wave height $\mathrm{H}_{s}$ as a function of the toe width $b_{t}$ for fixed damage levels $\mathrm{N}_{\mathrm{od}}$ for $\mathrm{h}=0.9 \mathrm{~m}, \mathrm{~h}_{\mathrm{m}}-\mathrm{h}_{\mathrm{t}}=0.15 \mathrm{~m}, \mathrm{D}_{\mathrm{n} 50}=0.025 \mathrm{~m}$

30. Significant wave height $H_{s}$ as a function of the toe width $b_{t}$ for fixed damage levels $\mathrm{N}_{\mathrm{od}}$ for $\mathrm{h}=0.9 \mathrm{~m}, \mathrm{~h}_{\mathrm{m}}-\mathrm{h}_{\mathrm{t}}=0.15 \mathrm{~m}, \mathrm{D}_{\mathrm{ns0}}=0.035 \mathrm{~m}$

31. Significant wave height $\mathrm{H}_{\mathrm{s}}$ as a function of the toe width $b_{t}$ for fixed damage levels $\mathrm{N}_{\mathrm{od}}$ for $\mathrm{h}=0.9 \mathrm{~m}, \mathrm{~h}_{\mathrm{m}}-\mathrm{h}_{\mathrm{t}}=0.15 \mathrm{~m}, \mathrm{D}_{\mathrm{n} 50}=0.040 \mathrm{~m}$

32a. Significant wave height $H_{s}$ as a function of the shallow water depth $h_{m}$ for fixed damage levels $\mathrm{N}_{\mathrm{od}}$ for $\mathrm{h}_{\mathrm{m}}-\mathrm{h}_{\mathrm{t}}=0.08 \mathrm{~m}, \mathrm{D}_{\mathrm{n} 50}=0.017 \mathrm{~m}$

32b. Significant wave height $H_{s}$ as a function of the shallow water depth $h_{m}$ for fixed damage levels $\mathrm{N}_{\mathrm{od}}$ for $\mathrm{h}_{\mathrm{m}}-\mathrm{h}_{\mathrm{t}}=0.08 \mathrm{~m}, \mathrm{D}_{\mathrm{nS0}}=0.025 \mathrm{~m}$

33a. Significant wave height $H_{s}$ as a function of the shallow water depth $h_{m}$ for fixed damage levels $\mathrm{N}_{o d}$ for $\mathrm{h}_{\mathrm{m}}-\mathrm{h}_{\mathrm{t}}=0.15 \mathrm{~m}, \mathrm{D}_{\mathrm{n} 50}=0.025 \mathrm{~m}$ 


\section{List of figures (continued)}

33b. Significant wave height $H_{s}$ as a function of the shallow water depth $h_{m}$ for fixed damage levels $\mathrm{N}_{\infty d}$ for $\mathrm{h}_{\mathrm{m}}-\mathrm{h}_{\mathrm{t}}=0.15 \mathrm{~m}, \mathrm{D}_{\mathrm{n} 50}=0.040 \mathrm{~m}$

34a. Significant wave height $H_{s}$ as a function of the toe height $h_{m}-h_{t}$ for fixed damage levels $\mathrm{N}_{\mathrm{od}}$ for $\mathrm{h}=0.8 \mathrm{~m}, \mathrm{D}_{\mathrm{n} 50}=0.025 \mathrm{~m}$

34b. Significant wave height $H_{s}$ as a function of the toe height $h_{m}-h_{t}$ for fixed damage levels $\mathrm{N}_{\mathrm{cd}}$ for $\mathrm{h}=0.9 \mathrm{~m}, \mathrm{D}_{\mathrm{n} 50}=0.025 \mathrm{~m}$

35a. Significant wave height $H_{s}$ as a function of the stone diameter $D_{n 50}$ for fixed damage levels $\mathrm{N}_{\mathrm{od}}$ for $\mathrm{h}=0.7 \mathrm{~m}, \mathrm{~h}_{\mathrm{m}}-\mathrm{h}_{\mathrm{t}}=0.08 \mathrm{~m}$

35b. Significant wave height $H_{3}$ as a function of the stone diameter $D_{n 50}$ for fixed damage levels $\mathrm{N}_{\mathrm{od}}$ for $\mathrm{h}=0.7 \mathrm{~m}, \mathrm{~h}_{\mathrm{m}}-\mathrm{h}_{\mathrm{t}}=0.15 \mathrm{~m}$

36. Significant wave height $H_{s}$ as a function of the stone diameter $D_{n 50}$ for fixed damage levels $\mathrm{N}_{\mathrm{od}}$ for $\mathrm{h}=0.9 \mathrm{~m}, \mathrm{~h}_{\mathrm{m}}-\mathrm{h}_{\mathrm{t}}=0.15 \mathrm{~m}$

37a. Significant wave height $\mathrm{H}_{\mathrm{s}}$ as a function of the stone diameter $\mathrm{D}_{\mathrm{n} 50}$ for fixed damage levels $\mathrm{N}_{\mathrm{od}}$ for $\mathrm{h}=0.8 \mathrm{~m}, \mathrm{~h}_{\mathrm{m}}-\mathrm{h}_{\mathrm{t}}=0.22 \mathrm{~m}$

37b. Significant wave height $H_{s}$ as a function of the stone diameter $D_{n 50}$ for fixed damage levels $\mathrm{N}_{\text {od }}$ for $\mathrm{h}=0.9 \mathrm{~m}, \mathrm{~h}_{\mathrm{m}}-\mathrm{h}_{\mathrm{t}}=0.22 \mathrm{~m}$

38a. Damage level $\mathrm{N}_{\mathrm{od}}$ as a function of the significant wave height $\mathrm{H}_{\mathrm{s}}$ for fixed stone diameters $D_{n s 0}$ for $h=0.7 m, h_{m}=0.3 m, h_{m}-h_{t}=0.08 m$

38b. Damage level $\mathrm{N}_{\mathrm{od}}$ as a function of the significant wave height $\mathrm{H}_{s}$ for fixed stone diameters $D_{n 50}$ for $h=0.7 m, h_{m}=0.3 m, h_{m}-h_{t}=0.15 m$

39a. Damage level $\mathrm{N}_{o d}$ as a function of the significant wave height $\mathrm{H}_{s}$ for fixed stone diameters $D_{n 50}$ for $h=0.8 m, h_{\mathfrak{m}}=0.4 m, h_{m}-h_{t}=0.08 m$

39b. Damage level $N_{o d}$ as a function of the significant wave height $H_{s}$ for fixed stone diameters $\mathrm{D}_{\mathrm{n} 50}$ for $\mathrm{h}=0.9 \mathrm{~m}, \mathrm{~h}_{\mathrm{m}}=0.5 \mathrm{~m}, \mathrm{~h}_{\mathrm{m}}-\mathrm{h}_{\mathrm{l}}=0.15 \mathrm{~m}$

40a. Damage level $\mathrm{N}_{\mathrm{od}}$ as a function of the significant wave height $\mathrm{H}_{\mathrm{s}}$ for fixed stone diameters $D_{n 50}$ for $h=0.9 m, h_{m}=0.5 m, h_{m}-h_{t}=0.15 m$

40b. Damage level $\mathrm{N}_{\mathrm{od}}$ as a function of the significant wave height $\mathrm{H}_{\mathrm{s}}$ for fixed stone diameters $D_{n 50}$ for $h=0.9 m, h_{m}=0.5 m, h_{m}-h_{t}=0.22 m$

41a. Damage level $\mathrm{N}_{\mathrm{od}}$ as a function of the significant wave height $\mathrm{H}_{\mathrm{s}}$ for fixed stone diameters $D_{n s 0}$ for $h=0.8 m, h_{m}=0.4 m, h_{m}-h_{t}=0.15 m$

41b. Damage level $N_{o d}$ as a function of the significant wave height $H_{s}$ for fixed stone diameters $D_{n s 0}$ for $h=0.8 m, h_{m}=0.4 m, h_{m}-h_{t}=0.22 m$ 


\section{List of figures (continued)}

42. Values of a for $h_{t} / h_{m}$ in $H_{s}=$ function* $N_{o d}{ }^{a}$

43. The stability number with damage level as a function of $h_{\mathfrak{l}} / h_{m}$

44. The stability number with damage level as a function of $h_{t} / h_{m}$

45a. Stability number with damage level as a function of $h_{l} / D_{n 50}$ for fixed toe heights and $\mathrm{h}=0.7 \mathrm{~m}$

45b. Stability number with damage levels as a function of $h_{\mathrm{l}} / \mathrm{H}_{s}$ for fixed toe heights and $\mathrm{h}=0.7 \mathrm{~m}$

46a. Stability number with damage level as a function of $h_{t} / D_{n 50}$ for fixed toe heights and $\mathrm{h}=0.8 \mathrm{~m}$

46b. Stability number with damage levels as a function of $h_{t} / H_{s}$ for fixed toe heights and $\mathrm{h}=0.8 \mathrm{~m}$

47a. Stability number with damage level as a function of $h_{l} / D_{n 50}$ for fixed toe heights and $\mathrm{h}=0.9 \mathrm{~m}$

47b. Stability number with damage levels as a function of $h_{\mathrm{t}} / \mathrm{H}_{s}$ for fixed toe heights and $\mathrm{h}=0.9 \mathrm{~m}$

48. Stability number with damage level as a function of $h_{t} / D_{n 50}$ smoothed dataset with fixed damage levels

49. Suggested stability formula as a function of the relative water depth $h_{m} / H_{s}$ smoothed dataset with fixed damage levels

50. Stability number with damage level as a function of $h_{\mathrm{t}} / \mathrm{D}_{\mathrm{n} 50}$ original dataset

51. Suggested stability formula as a function of the relative water depth $\mathrm{h}_{\mathrm{m}} / \mathrm{H}_{\mathrm{s}}$ original dataset

52. Stability number with $2 \%$ wave height with damage level as a function of $h_{\mathfrak{l}} / D_{n 50}$

53. Suggested stability formula with $2 \%$ wave height as a function of the relative water depth $\mathrm{h}_{\mathrm{m}} / \mathrm{H}_{2 \%}$

54. Stability number with damage level as a function of $h_{t} / D_{n 50}$ existing testdata

55. Stability number with damage level as a function of $h_{t} / D_{n 50}$ existing testdata with $\mathrm{N}_{\mathrm{od}}>0.5$ 


\section{Notation}

$\begin{array}{lll}\mathrm{D}_{\mathrm{n} 50} & =\text { nominal diameter }(\mathrm{M} / \rho)^{1 / 3} & (\mathrm{~m}) \\ \mathrm{h} & =\text { deep water depth } & (\mathrm{m}) \\ \mathrm{h}_{\mathrm{m}} & =\text { shallow water depth at structure } & (\mathrm{m}) \\ \mathrm{H}_{\mathrm{m} 0} & =\text { significant wave height based on wave energy density spectrum, }(\mathrm{m} 0)^{1 / 2} & (\mathrm{~m}) \\ \mathrm{H}_{\mathrm{s}} & =\text { significant wave height, average of highest } 1 / 3 \text { of all waves } & (\mathrm{m}) \\ \mathrm{H}_{\mathrm{s} 0} & =\text { significant wave height near the wave board } & (\mathrm{m}) \\ \mathrm{H}_{2 \%} & =2 \% \text { wave height } & (\mathrm{m}) \\ \mathrm{h}_{\mathrm{t}} & =\text { depth above the toe structure } & (\mathrm{m}) \\ \mathrm{b}_{\mathrm{t}} & =\text { width of the toe structure } & (\mathrm{m}) \\ \mathrm{m} 0 & =\text { zeroth moment of wave energy spectrum } & (\mathrm{m}) \\ \mathrm{s}_{\mathrm{op}} & =\text { fictitious wave steepness }\left(2 \mathrm{H}_{\mathrm{s}}\right) /\left(\mathrm{gT}_{\mathrm{p}}{ }^{2}\right) & (\mathrm{m}) \\ \mathrm{T}_{\mathrm{p}} & =\text { peak wave period } & (\mathrm{s}) \\ \mathrm{T}_{\mathrm{m}} & =\text { mean wave period } & (\mathrm{s}) \\ \rho_{\mathrm{s}} & =\text { mass density of stones } & \left(\mathrm{kg} / \mathrm{m}^{3}\right) \\ \rho_{\mathrm{w}} & =\text { mass density of water } & \left(\mathrm{kg} / \mathrm{m}^{3}\right)\end{array}$




\section{Introduction}

\subsection{General}

Two types of breakwaters can be distinguished. Firstly the monolithic breakwater where the structure consists of a monolithic structure. The other type of breakwater is a rubble mound breakwater.

A rubble mound breakwater can be designed as a static or as a dynamic structure. In a dynamic structure the stability of the breakwater consists of the individual stones moving to a more stable situation but the total structure remains stable.

In a statically stable breakwater the individual stones are stable and therefor the total breakwater is stable.

The present report will be restricted to static rubble mound breakwaters.

Rubble mound breakwaters consist of several layers and parts. The various parts can be found in Figure 1.

The various parts of the breakwater have their own function.

The function of the toe structure is to support the armour layer. If the toe structure would not be present the armour layer of the breakwater could slide down the slope under wave attack. The underlayer could become exposed to wave attack, then introduce more damage and the breakwater could eventually loose its function and be destroyed.

This report contains an analysis on the stability of the toe structure of rubble mound breakwaters.

Although the toe structure is an essential part of the breakwater only very little is known about toe stability, in this study it is tried to extend the knowledge on toe structure stability of rubble mound breakwaters.

The study was performed by E. Gerding, student at Delft University of Technology, as part of his Master's thesis, under the guidance of Prof. K. d'Angremond (TU Delft), Dr. J.W. van der Meer (Delft Hydraulics), Dr. J van de Graaff (TU Delft) and K.G. Bezuyen (TU Delft). In February 1993, the author performed a series of tests on toe stability at Delft Hydraulics.

In Chapter 2 the existing knowledge on toe stability will be given. In Chapter 3 the governing parameters and their influence will be discussed based on the existing knowledge. In Chapter 4 the tests performed for the present study will be treated and in the Chapters 5 , 6 and 7 the actual analysis both qualitative and quantitative of the test results will be presented.

In Chapter 8 the results will be compared with the results from existing tests.

The author wishes to acknowledge Delft Hydraulics for the use of test facilities and the guidance. 


\subsection{Aim of the research}

Until now the knowledge of toe structure stability of rubble mound breakwaters is limited and not based on systematic research.

The aim of this study is to come up with a formula for toe stability in which most governing parameters for toe stability are included.

This formula should be practically applicable and reasonably reliable.

\subsection{Conclusions and recommendations}

1. The main governing parameters, which determine toe stability in rubble mound breakwaters, are:

significant wave height : $\mathrm{H}_{\mathrm{s}}$

nominal stone diameter : $\quad D_{\mathrm{n} 50}$

stone mass density $: \rho_{s}$

depth above the toe $: \mathrm{h}_{\mathbf{t}}$

damage level $\quad: \mathrm{N}_{\mathrm{od}}$

2. Parameters investigated which had no significant influence are: the fictitious wave steepness $s_{o p}$ and the width of the toe structure $b_{t}$.

3. Only one cross section of a rubble mound breakwater with various rock toe structures was investigated.

4. The damage level can be classified as:

$\mathrm{N}_{\mathrm{od}}=0.5$ hardly any damage

$\mathrm{N}_{\mathrm{od}}=2$ acceptable damage, design criteria

$\mathrm{N}_{\mathrm{od}}=4$ unacceptable damage

For wider toe structures a higher damage level $\mathrm{N}_{\text {od }}$ could be acceptable.

5. Because the relation between the shallow water significant wave height $\mathbf{H}_{s}$ and the nominal stone diameter $\mathrm{D}_{\mathrm{n} 50}$ is linear but is not linear through the origin, the stability number $\mathbf{H}_{\mathrm{s}} / \Delta \mathrm{D}_{\mathrm{n} 50}$ can not be used to fully describe toe stability without introducing a bias in the results with a considerable scatter.

6. When the stability number is used the introduced bias can be compensated when one of the parameters in the stability number is used again in a dimensionless parameter $h_{\mathfrak{l}} / D_{n 50}$ is preferred above $h_{\mathfrak{l}} / H_{s}$.

7. When the results from the present test series are compared with the best relation on toe stability so far (van der Meer, CUR, 1991) the trend in both relations is the same but the relation by van der Meer gave lighter toe structures than with the present test results. 
8. Toe stability can be described with the relation:

$$
\frac{H_{s}}{\Delta D_{n 50}}=\left(0.24 \frac{h_{t}}{D_{n 50}}+1.6\right) N_{o d}^{0.15}
$$

For depth limited situations the $2 \%$ wave height could give more accurate results with the relation:

$$
\frac{H_{2 t}}{\Delta D_{n 50}}=\left(0.34 \frac{h_{t}}{D_{n 50}}+2.2\right) N_{o d}^{0.15}
$$

Improvement in accuracy can be achieved using the $2 \%$ wave height. With the present test results the larger scatter in the $2 \%$ wave height caused a larger scatter around the proposed relation.

Both found relations can be used for:

$0.4<h_{\mathrm{h}} / h_{\mathrm{m}}<0.9$
$3<\mathrm{h}_{\mathrm{l}} / \mathrm{D}_{\mathrm{n} 50}<25$

9. If the relations found in the present study are compared with existing test results the same trend is found but the values from the existing test results show a higher stability of the toe structure than with the relation found in the present study.

10. It is recommended to perform further research into the influence on toe stability of the shape of the foreshore, the breakwater outline and the stone mass density. 


\section{Overview of existing knowledge}

The existing knowledge of the stability of toe structures is limited. Most design rules are based on practical knowledge.

The Shore Protection Manual (SPM, 1984) gives design rules for the toe structure. The weight of the stones in the toe structure is related to the weight of the stones in the armour layer.

In the case of the SPM the stones in the toe structure should have a weight of $1 / 10$ of the weight of the stones in the armour layer.

The SPM also gives a width of the toe structure of 2 or 3 stones. Other measures for the toe structure are not given.

Only little research into the stability of toe structures has been done.

The Shore Protection Manual (SPM, 1984) shows results of Brebner and Donnelly (1962), who tested toe structures under monochromatic waves. A relationship is assumed between the ratio $h_{t} / h$ and the stability number $H / \Delta D_{n 50}$, where $h_{t}$ is the depth of the toe below the water level and $h$ is the water depth. A small ratio of $h_{\mathrm{l}} / \mathrm{h}=0.3-0.5$ means that the toe is relatively high above the bottom. In that case the toe structure is more a berm structure. A value of $h_{t} / h=0.8$ means that the toe is near the bottom. $H / \Delta D_{n 50}$ values, using a regular wave height $H$, of 6-7 are recommended if $h_{t} / h>0.5$.

Sometimes a relationship between $H_{s} / \Delta D_{n 50}$ and $h_{t} / H_{s}$ is assumed where a lower value of $h_{t} / H_{s}$ should give more damage. Gravesen and Sørensen (1977) describe that a high wave steepness (short wave period) gives more damage to the toe than a low wave steepness. Above mentioned assumption was based on only a few points. In the CIAD report (1985) this conclusion could not be verified. No relationship was found there between $H_{s} / \Delta D_{n 50}$ and $h_{t} / H_{s}$, probably because $H_{s}$ is present in both parameters. An average value of $H_{s} / \Delta D_{n s 0}=4$ was given for no damage and a value of 5 for failure. The standard deviation around these values was 0.8 , showing a large scatter.

A more in depth study was performed by Van der Meer (CUR, 1991).

In that study seven breakwater test series were taken from existing reports and the behaviour of the toe was examined.

Three damage criteria were established based on the percentage of removed stones from the original toe structure:

0-3\% no movement of stones (or only a few) in the toe.

$3-10 \%$ the toe flattened out a little, but the function of the toe (supporting the armour layer) was intact and the damage is acceptable.

$>20-30 \%$ failure; the toe has lost its function and this damage level is not acceptable.

In almost all cases the structure was attacked by waves in a more or less depth limited situation which means that $\mathrm{H}_{s} / \mathrm{h}$ was near to 0.5 .

In the study by Van der Meer $H_{s} / \Delta D_{n 50}$, the strength parameter is related to $h_{l} / h$.

The result of this study can be found in Figure 2 . 
From this the design values for low and acceptable damage $(0-10 \%)$ and for more or less depth limited situations were found.

They were:

$\begin{array}{ll}\mathrm{h}_{\mathrm{t}} / \mathrm{h} & \mathrm{H}_{\mathrm{s}} / \Delta \mathrm{D}_{\mathrm{n} 50} \\ 0.5 & 3.3 \\ 0.6 & 4.2 \\ 0.7 & 5.2 \\ 0.8 & 6.3\end{array}$

The relation found can be given by:

$$
{\frac{h_{t}}{h_{m}}}=0.22{\frac{H_{s}}{\Delta \bar{D}_{250}}}^{0.7}
$$

As this relation is based on only a limited number of points the reliability of these values is also limited. This relation is based on depth limited test results. Toe width and wave length are not included in the design values. 


\section{Governing parameters}

\subsection{Governing parameters}

The stability of the toe structure is influenced by several governing parameters. These parameters with dimensions can be found in Figure 3.

These governing parameters are:

$\begin{array}{lll}\text {-Wave } & \text {-significant wave height } & \mathrm{H}_{\mathrm{m} 0} \text { or } \mathrm{H}_{\mathrm{s}}(\mathrm{m}) \\ & \text {-peak period } & \mathrm{T}_{\mathrm{p}}(\mathrm{s}) \\ & -2 \% \text { wave height } & \mathrm{H}_{2 \%}(\mathrm{~m}) \\ \text {-Toe structure } & \text {-water depth at structure } & \mathrm{h}_{\mathrm{m}}(\mathrm{m}) \\ & \text {-depth above the toe } & \mathrm{h}_{\mathrm{t}}(\mathrm{m}) \\ & \text {-width of the toe structure } & \mathrm{b}_{\mathrm{t}}(\mathrm{m}) \\ & \text {-nominal stone diameter } & \mathrm{D}_{\mathrm{ns} 0}(\mathrm{~m}) \\ \text {-Damage } & \text {-mass density stones } & \rho_{\mathrm{s}}\left(\mathrm{kg} / \mathrm{m}^{3}\right) \\ & & \% \text { or } \mathrm{N}_{\mathrm{od}}\end{array}$

From the governing parameters some other parameters can be derived.

With dimension: height of the toe $h_{m}-h_{t}(m)$.

Dimensionless parameters: wave steepness: $\mathrm{s}_{\mathrm{op}}=\left(2 \pi \mathrm{H}_{\mathrm{m} 0}\right) /\left(\mathrm{g}^{*} \mathrm{~T}_{\mathrm{p}}{ }^{2}\right)$

relative density: $\Delta=\left(\rho_{\mathrm{s}}-\rho_{\mathrm{w}}\right) / \rho_{\mathrm{w}}$

with $\rho_{s}=$ mass density stones

and $\rho_{\mathrm{w}}=$ mass density water.

The damage can be given as a percentage, than the number of stones displaced from the toe structure is given as a percentage of the total number of stones in the toe structure.

The disadvantage of this system is that if the same number of stones is displaced from different toe structures (a higher or wider toe) the percentage changes but the amount of damage or the damage profile is actually the same.

For this reason the damage number $\mathrm{N}_{\mathrm{od}}$ is used in this report.

$\mathrm{N}_{\mathrm{od}}$ is defined as the number of stones removed from the toe structure in a strip with a width of $1 \mathrm{D}_{\mathrm{ns0}}$.

The advantage of using the damage number $\mathbf{N}_{\mathrm{od}}$ is that the damage is not related to height or width of the toe structure and the same amount of moved stones give the same damage area for all toe shapes.

In this way the amount of damage is independent of the shape of the toe structure. It should be noted however that the effect of a certain damage level on several toe structures is different with the shape of the toe structure. 


\subsection{Influence of parameters}

A brief review of the influence of parameters from previous research is given first for every parameter.

\subsubsection{Significant wave height, $\mathrm{H}_{\mathrm{s}}$ or $\mathrm{H}_{\mathrm{mo}}$}

Of course a higher wave gives more damage.

From Van der Meer (CUR, 1991) this can be found in the stability number $H_{s} / \Delta D_{n 50}$. This shows that a bigger stone is needed to maintain the same stability if a higher wave is introduced.

\subsection{2 $2 \%$ wave height, $\mathrm{H}_{2 \%}$}

Like with $\mathrm{Hs}$ a higher $\mathrm{H}_{2 \%}$ gives more damage. The advantage of using $\mathrm{H}_{2 \%}$ over $\mathrm{H}_{s}$ is that in $\mathrm{H}_{2 \%}$ the influence of a depth limited situation is better considered than with $\mathrm{H}_{s}$.

The highest waves cause the damage to the structure. $\mathrm{H}_{2 \%}$ is nearer to the highest waves than $\mathrm{H}_{s}$ so the deviation from the highest waves is smaller when $\mathrm{H}_{2 \%}$ in stead of $\mathrm{H}_{s}$ is used.

\subsubsection{Shallow water depth, $h$}

A larger water depth will give less damage.

In Van der Meer (CUR, 1991) this can be found in the $h_{l} / h_{m}$ ratio, if this parameter decreases this will lead to a larger stability, than a smaller stone diameter $D_{n 50}$ or a higher significant wave height $\mathrm{H}_{s}$ can be accepted.

\subsubsection{Depth above the toe, $h_{t}$}

A larger depth above the toe $h_{t}$, will lead to less damage.

In Van der Meer (CUR, 1991) it can be concluded from the ratio $h_{l} / h_{m}$ where a larger $h_{t}$ leads to a larger stability of the toe structure.

\subsubsection{Armour size, $D_{\text {n50 }}$}

A larger stone leads to less damage.

In Van der Meer (CUR, 1991) this can be found in the stability number $H_{s} / \Delta D_{n 50}$. In this a larger stone (larger $D_{n 50}$ ) leads to a larger stability of the toe structure, because then a larger significant wave height $\mathrm{H}_{\mathrm{s}}$ can be accepted. 


\subsubsection{Mass density $\rho_{s}$}

A higher mass density $\rho_{\mathrm{s}}$ leads to less damage.

In Van der Meer (CUR, 1991) this can be seen from the stability number $H_{s} / \Delta D_{n s 0}$ where the density is in the $\Delta$-parameter $\left(\left(\rho_{s}-\rho_{\mathrm{w}}\right) / \rho_{\mathrm{w}}\right)$.

If the $\Delta$ (and $\rho_{\mathrm{s}}$ ) is higher this will lead to a higher stability of the toe structure. This effect has only been found for the armour layer (Van der Meer, 1989) and is assumed to be correct for toe structures although no research into this effect for toe structures has been performed.

\subsubsection{Peak wave period, $T_{p}$ or wave steepness, $s_{o p}$}

Gravesen and Sørensen (1977) are the only ones who describe the influence of period or wave steepness. They suggest that a high wave steepness or a short wave period gives more damage than a low wave steepness or a long wave period for the same wave height.

\subsubsection{Width of the toe structure, $b_{\text {, }}$}

Although no study has been done into influence of the width of the toe, it is thought that a wider toe is more stable than a smaller toe structure and would therefor give less damage. For a wider toe structure at least more damage is tolerable. 


\section{Description of laboratory tests}

\subsection{Wave flume}

The tests for the present study were performed in the "Schelde" flume at Delft Hydraulics. The length of this flume is $50 \mathrm{~m}$, the width $1.0 \mathrm{~m}$ and the depth $1.2 \mathrm{~m}$.

An overview of the test set-up is given in Figure 4.

For the tests a foreshore of $1: 20$ was available in the flume on which the structure was placed at $18 \mathrm{~m}$ from the wave board.

\subsection{Wave characteristics}

Before performing tests with the structure in the flume, a set of tests were performed without the structure to determine the wave characteristics. For this purpose 4 wave gauges were placed in the flume, 2 placed about a quarter of a wave length apart in front of the wave board at the deep end of the flume and 2 wave gauges were placed at the site where in the actual tests the structure would be placed. This was done to determine the relationship between the wave height and wave period in deep and shallow water for several water depths.

In the Figures 8-10 the results from these tests can be found for deep water depths of $0.7 \mathrm{~m}$, $0.8 \mathrm{~m}$ and $0.9 \mathrm{~m}$.

In the figures the exceedance curves of the wave height and the wave energy density spectra for a desired significant wave height of $\mathbf{H}_{\mathrm{s}}=0.25 \mathrm{~m}$ at the wave board can be found.

It can be clearly seen from the results of wave gauge no. 1 near the wave board and wave gauge no. 3 at the position of the structure that the reduction in wave height caused by breaking on shallow water is present, especially for smaller water depths.

\subsection{Tests}

The tests concentrated on the governing parameters as described before.

This means variations were investigated in: water depth, wave height, wave period or wave steepness and for the structure variations were tested in stone diameter, toe height and toe width.

To get a good insight in the influence of all parameters separately only one parameter was changed at a time. To achieve so the tests were performed with two fixed values of the wave steepness 0.02 and 0.04 and three fixed values of the significant wave height of $0.15 \mathrm{~m}$, $0.20 \mathrm{~m}$ and $0.25 \mathrm{~m}$ at the wave board.

Some additional tests were performed with a wave steepness of 0.03 .

The toe structure was divided over the width of the wave flume into three parts. In this way three stone diameters could be tested in one test set up. The stone diameters used in the tests were $D_{\text {n50 }}=0.017 \mathrm{~m}, 0.025 \mathrm{~m} 0.035 \mathrm{~m}$ and $0.040 \mathrm{~m}$ with $\mathrm{D}_{85} / \mathrm{D}_{15}=1.15-1.30$. A range of toe heights and toe widths were investigated for each combination of wave steepness and wave height.

In Figure 5 the tested breakwater cross section can be found with the tested variations in water depth, toe height and the width of the toe structures tested. 
Out of a total of 65 planned tests 57 tests were performed.

Some planned tests were not performed because the tests before the planned test with a lower wave height and the same wave steepness had already given a destroyed toe structure after the test was performed. So the larger wave height in the planned test was not needed for new information and was therefor not performed.

An overview of the combinations of parameters which were tested is given in Table 1.

Each test consisted of about 1000 waves.

These waves were generated by the wave board which was controlled by signals from a computer which contained a preset Jonswap wave energy density spectrum.

During the tests the significant wave height $\mathrm{H}_{s}$, the significant wave height from the wave energy density spectrum $\mathrm{H}_{\mathrm{m} 0}$, the $2 \%$ wave height $\mathrm{H}_{2 \%}$, the average wave period and the peak wave period were determined.

The measured values for each of the tests are given in Table 2.

In this table the wave characteristics both at deep water and at the position of the toe structure are given. The shallow water wave heights at the structure were determined from the wave characteristics obtained in the tests without the structure in the flume (Figures 6 and 7). In table 2 the properties of the toe structures tested are given as well as the damage measured after the tests.

This damage was obtained by counting and weighing the total number of stones removed out of the original bed of the toe structure and then dividing that by the total number and weight of the stones in the toe structure. The damage number $\mathrm{N}_{\mathrm{od}}$ was obtained by dividing the number of stones removed from the original toe structure by the number of stones in a strip with a width of $1 D_{n 50}$.

The relationship for the wave heights $\left(\mathrm{H}_{\mathrm{s}}\right.$ and $\left.\mathrm{H}_{2 \%}\right)$ at deep and shallow water from the tests without the structure in the flume are presented in Figures 6 and 7 to determine the wave characteristics. They are given for wave steepness 0.02 and 0.04 and water depths of $0.9 \mathrm{~m}$, $0.8 \mathrm{~m}$ and $0.7 \mathrm{~m}$ at the wave board and $0.5 \mathrm{~m}, 0.4 \mathrm{~m}$ and $0.3 \mathrm{~m}$ at the structure, respectively.

From these figures it can clearly be seen that for the lower water depths the reduction of the wave height at the structure due to breaking is larger than for larger water depths.

These conclusions show that particularly the lower water depths and higher wave heights create a depth limited situation.

Normally the ratio of $\mathrm{H}_{2 \%} / \mathrm{H}_{s}$ is about 1.4 in deep water situations due to the Rayleigh distribution of the wave heights.

In depth limited situations this is not longer the case.

In Fig. 7 the ratio $\mathrm{H}_{2 \%} / 1.4 \mathrm{H}_{s}$ is shown as a function of the relative water depth $h_{m} / H_{s}$. A clear trend is shown where the ratio $\mathrm{H}_{2 \%} / 1.4 \mathrm{H}_{s}$ decreases with decreasing relative water depth. This means that for small relative water depths the wave height distribution is no longer a Rayleigh distribution, but that higher waves broke more than the lower waves, causing a truncated distribution.

Thus, a depth limited situation was present during the tests with low relative water depths. 


\section{Analysis of results}

\subsection{Introduction}

The data obtained in the laboratory tests as described before will be used for an analysis of the influence of the governing parameters.

First this will be done by means of a qualitative analysis.

In this analysis the influence of each parameter is considered, still with dimensions and only the trend is described.

After this a quantitative analysis will be made in which the parameters will be used in a dimensionless form.

With this approach an attempt will be made to derive a formula for the stability of toe structures in breakwaters from the test data. It is tried to consider all parameters separately. In this way a formula can be found in which the influence of each single parameter is included.

\subsection{Analysis of damage curves}

To make a good analysis possible it is required to change only one parameter and keep the other parameters constant. In this way it can be reviewed how that parameter affects the stability of the toe structure.

In this case $\mathbf{H}_{s}$ is the parameter representing the stability of the toe structure in the way that a higher significant wave height $\mathrm{H}_{\mathrm{s}}$ is needed for the same damage level the toe structure is more stable. $\mathrm{H}_{s}$ reacts to changes in the other governing parameters.

All the governing parameters were tested with constant levels of the parameters. The test result of the damage level $\mathbf{N}_{\mathrm{od}}$ varies with no constant levels.

The damage level $\mathrm{N}_{\mathrm{od}}$ must also be classified and preset constant damage levels are required.

Van der Meer (CUR, 1991) suggested a damage criteria using the percentage of stones removed from the original toe structure of:

0-3\%. no movement of stones (or only a few) in the toe

$3-10 \%$ toe flattened out a little but the function of the toe (supporting the armour layer) is intact and the damage is acceptable

$>20-30 \%$ failure; the toe has lost its function and this damage level is not acceptable

In Table 2 the percentage of removed stones and the corresponding damage level $\mathrm{N}_{o d}$ from the present test series can be found.

Considering the damage level with percentages suggested by Van der Meer the corresponding damage levels using $\mathrm{N}_{\mathrm{od}}$ from the present test series are:

$\mathrm{N}_{o d}<0.5$ hardly any damage

$\mathrm{N}_{\text {od }}$ 0.5-2.0 acceptable damage, design criteria

$\mathrm{N}_{\mathrm{od}}>4.0$ unacceptable damage, toe structure has lost its function

The damage levels $\mathrm{N}_{\mathrm{od}}$ of $0.5,2$ and 4 will be used as constant damage levels in the further analysis.

In order to get the classified $\mathrm{N}_{o d}$ in the dataset all test data were plotted in figures with a constant wave steepness $s_{\text {op }}$, deep water depth $h$, toe height $h_{m}-h_{t}$ and toe width $b_{t}$. 
In one figure the damage level $\mathrm{N}_{\mathrm{od}}$ is plotted for varying shallow water wave height $\mathrm{H}_{\mathrm{s}}$ and for 3 tested stone diameters $D_{n 50}$. The shallow water wave height is used because the wave height at the structure causes the damage to the structure so that will determine the stability of the toe structure.

These damage curves can be found in the Figures 12-22.

From these damage curves the shallow water significant wave height $\mathrm{H}_{s}$ was determined for a damage level $\mathrm{N}_{\mathrm{od}}$ of $0.5,2$ and 4 as can be seen in the figures from the horizontal lines.

The values of $\mathrm{H}_{s}$ for the damage levels were determined to be the values for which the damage curves cross the horizontal lines for constant damage levels. If the damage curve does not reach a certain damage level no value for $H_{s}$ is determined for that damage level $\mathrm{N}_{\text {od }}$.

In this way a new dataset was obtained with fixed values of $s_{o p}, h, h_{m}-h_{t}, b_{t}, D_{n 50}, N_{o d}$ and varying $\mathrm{H}_{\mathrm{s}}$.

This new dataset can be found in Table 3 .

With this new dataset it is possible to consider all parameters separately and the influence of each single parameter will clearly appear.

\subsection{Influence of the wave steepness $s_{\text {op }}$}

For the analysis of the influence of the wave steepness the significant wave height $\mathrm{H}_{s}$ at shallow water was plotted for varying wave steepness $s_{\text {op }}$ for several constant damage levels $N_{o d}$ and constant water depth $h$, toe height $h_{m}-h_{t}$, toe width $b_{t}$ and stone diameter $D_{n 50}$.

These graphs can be found in the Figures 23-26.

In these figures a clear trend can be found. From the figures it can be seen that the average trend of the lines is horizontal. This means that for a varying wave steepness $s_{o p}$ and a constant damage level $\mathrm{N}_{o d}$ the significant wave height $\mathrm{H}_{3}$ does not change.

Although not all figures show a horizontal trend (like Figure 26b) the average trend is a constant significant wave height for a constant damage level if the wave steepness changes.

The conclusion from these figures must therefor be that the wave steepness $s_{\mathrm{op}}$ has no clear influence on the stability of the toe structure. Because of the limited number of results this must be verified in the future.

Another indication for this conclusion is the use of the original test results (in Table 2) with the few extra tests that were performed with a wave steepness $s_{\mathrm{op}}=0.03$.

If for a constant $h, h_{m}-h_{t}, b_{t}$ and $D_{n s 0}$ the damage level $N_{o d}$ is plotted for the shallow water wave height $\mathrm{H}_{3}$ from the original test results in a damage curve like in the Figures 28 and 29 it can be concluded that all the points are on one line and there is no variation for different values of $s_{\mathrm{op}}$. This leads to the conclusion that the wave steepness has no influence on the damage to the toe structure.

From here on the wave steepness will no longer be regarded as a governing parameter for the stability of toe structures and the results of $s_{\mathrm{op}}=0.02$ and $\mathrm{s}_{\mathrm{op}}=0.04$ will be put together.

\subsection{Influence of the toe width $b_{t}$}

In the Figures 29,30 and 31 the shallow water significant wave height $H_{s}$ is plotted for the toe width $b_{t}$ for constant damage levels $N_{o d}$ and constant deep water depth $h$, toe height $h_{m}-h_{t}$ and stone diameter $\mathrm{D}_{\mathrm{n} 50}$.

From these figures a clear trend can be seen. 
The average trend is that a constant wave height can be found for varying toe width if a constant damage level is reviewed.

Some figures suggest a larger toe stability with a wider toe structure (Figure 31) but when all figures are considered the average trend is a horizontal line.

The conclusion must therefor be that the width of the toe structure has no influence on the stability of the toe structure.

From here on the toe width will no longer be regarded as a governing parameter for the stability of the toe structure and the various levels of the toe width will be put together.

It can however be suggested that for a wider toe structure more damage is acceptable if the damage is defined by the damage number $\mathrm{N}_{\mathrm{od}}$.

$\mathrm{N}_{\mathrm{od}}$ is defined as the number of stones removed from a strip with a width of $1 \mathrm{D}_{\mathrm{n} 50}$. A narrower toe structure is more sensitive to a strip of stones removed from the toe structure than a wider toe; a narrower toe will be destroyed at a lower damage level $\mathrm{N}_{o d}$ than a wider toe structure.

It can therefor be suggested that for wider toe structures a higher damage level $\mathrm{N}_{\mathrm{od}}$ is acceptable as a design criteria than for a narrower toe. This could lead to the conclusion that for wider toes a damage percentage is more suitable.

Further research into the levels of these new design damage levels $\mathrm{N}_{\mathrm{od}}$ for wider toe structures is needed.

\subsection{Influence of the shallow water depth $h_{m}$}

In the Figures 32 and 33 the shallow water significant wave height $\mathrm{H}_{s}$ is shown as a function of the shallow water depth at the structure $h_{m}$ for constant damage levels $N_{o d}$ and several levels of the toe height $h_{m}-h_{t}$ and the stone diameter $D_{n 50}$.

It turns out that with a larger water depth a larger wave height is required to cause the same damage level.

This seems logical because with a higher water level the toe structure is deeper under water and the waves have to be higher to have the same effect and cause the same damage to the toe structure on that depth.

The trend that can be derived from the figures is that the relation between the significant wave height and the shallow water depth is linear but not through the origin.

\subsection{Influence of the toe height $h_{m}-h_{t}$ or the depth above toe $h_{t}$}

In Figure 34 the shallow water significant wave height $H_{s}$ is plotted for the toe height $h_{m}-h_{t}$ for constant damage levels $\mathrm{N}_{o d}$ and several levels of the water depth $\mathrm{h}$ and the stone diameter $\mathrm{D}_{\mathrm{n} 50 \text {. }}$.

From this figure it can be concluded that a higher toe structure (larger $h_{m}-h_{l}$ ) gives more damage to the toe structure.

The explanation for this trend is the same as with the influence of the shallow water depth $h_{m}$. If the structure is closer to the water level, the influence of the waves is larger than if the toe structure would be deeper under water and closer to the original bottom level. Now a smaller wave height is sufficient to cause the same damage level. 


\subsection{Influence of the stone diameter $D_{n 50}$}

In the Figures 35, 36 and 37 the significant wave height in shallow water $\mathrm{H}_{s}$ is plotted for the stone diameter $D_{n 50}$ for constant damage levels $N_{o d}$ and several levels of the deep water depth $h$ and the toe height $h_{m}-h_{t}$.

From these figures it can be seen that stones with a larger diameter are more stable because a larger stone diameter requires a higher significant wave height to cause the same damage level.

This is a well known tendency that is often found in breakwater design.

The relation between the stone diameter $D_{n 50}$ and the significant wave height at shallow water $\mathrm{H}_{\mathrm{s}}$ seems to be linear but is not linear through the origin.

A relation often used in breakwater design is $H_{s} /\left(\Delta D_{n 50}\right)$. This relation is known as the stability number.

If the stability number is used the relation between $D_{\mathrm{n} 50}$ and $H_{s}$ is supposed to be linear through the origin. As this is not the case here the stability number $H_{s} /\left(\Delta D_{n 50}\right)$ can not be used here as a relation that describes the stability of the toe structure completely.

If the stability number is used to fully describe the stability a bias is introduced because a line through the origin is supposed which is actually not present. With this a considerable scatter is introduced in the results of the analysis.

An explanation for the relation not going through the origin and therefor the stability number not being applicable here is that the stability number is normally used for cases where there is direct wave attack on an armour layer.

In the case of a toe structure in a breakwater the waves are not attacking directly on the toe structure.

This means that a wave can attack the breakwater and cause damage to the armour layer but no damage to the toe structure.

Therefor the relation is linear (like with the armour layer) but not through the origin.

Although the stability number is not the only parameter for toe structure stability it will first be used because design criteria for toe structures (Van der Meer, CUR, 1991) use it directly. In the present study the formula by Van der Meer will be examined and the scatter that will be introduced by using the stability number to fully describe toe stability is accepted.

After that a new analysis will be made using the stability number and additional parameter to fully describe the stability of the toe structure. 


\section{Relation with the damage level $\mathbf{N}_{\text {od }}$}

\subsection{Analysis}

For a quantitative analysis of the test results the relation with the damage level $\mathrm{N}_{\mathrm{od}}$ will be determined.

The relation that can best be used in the further analysis is the relation between the damage level $\mathrm{N}_{o d}$ and the significant wave height in shallow water $\mathrm{H}_{s}$ because the significant wave height will be used in every relation as the parameter to describe toe stability.

To determine this relation the damage curves in which the damage level $\mathrm{N}_{\mathrm{od}}$ is plotted as a function of the shallow water wave height $\mathrm{H}_{\mathrm{s}}$ for the stone diameters used, several shallow water depths $h_{m}$ and toe heights $h_{m}-h_{t}$. This can be found in the Figures 38-41.

Through the points in the figures the best fit seems to be a power curve. For some series of points a straight line seems a better fit (like in the figures $39 \mathrm{a}$ and b) but the total tendency is that a power curve is the best fit through the points.

The suggested relation between the damage level and the significant wave height is of the form:

$$
H_{s}=b * N_{o d}{ }^{a} \text { with } b \text { a function of other parameters }
$$

This function will be determined later in the present study.

The power "a" of the damage level $\mathbf{N}_{\mathrm{od}}$ can be determined from the damage curves (Figures 38-41).

As can be seen from the damage curves in the Figures 38-41 the scatter in the values of the power " $\mathrm{a}$ " of $\mathrm{N}_{\mathrm{od}}$ is large. Because of this scatter the minimum and maximum acceptable values of the power " $\mathrm{a}$ " of $\mathrm{N}_{\mathrm{od}}$ were determined for every figure on logarithmic graphs.

In Figure 42 the minimum and maximum values of the power "a" of $\mathrm{N}_{\mathrm{od}}$ are shown for $\mathrm{h}_{\mathrm{h}} / \mathrm{h}_{\mathrm{m}}$.

From this figure the best value of " $a$ " was determined to be 0.15 .

The suggested relation between the damage level $\mathrm{N}_{\mathrm{od}}$ and the significant wave height at shallow water $\mathrm{H}_{\mathrm{s}}$ now becomes:

$$
\mathbf{H}_{s}=b^{*} \mathbf{N}_{\mathrm{od}}^{0.15}
$$

This relation will be used in the further quantitative analysis of the toe stability. 


\section{Quantitative analysis with the stability number $H_{s} / \Delta D_{n 50}$}

\subsection{Introduction}

As was shown before this the stability number $H_{s} / \Delta D_{n 50}$ is not the parameter to fully describe toe stability because the relation between $H_{s}$ and $D_{n 50}$ is linear but not through the origin. Existing knowledge however is based on the stability number being related to the depth in front of the structure $h_{m}$ and the depth above the toe $h_{t}$ (Van der Meer, CUR, 1991) to describe toe stability.

To compare the present data with the existing knowledge the stability number will be used here in the way it is suggested by Van der Meer.

In figure $37 \mathrm{~b}$ the deviation introduced by using $\mathrm{H}_{\mathrm{s}} / \Delta \mathrm{D}_{\mathrm{n} 50}$ is illustrated.

The line through the origin is the supposed line when the stability number is used directly. The other line is the actual situation with the present data. It can be seen that on the outer sides of the data used, the difference between the supposed and the real situation is considerable.

By using $H_{s} / \Delta D_{n 50}$ a bias is introduced. This means that the toe stability is overestimated if a large stone diameter $D_{n 50}$ is used and the toe stability is underestimated when a small stone diameter $D_{n s 0}$ is used.

In the next analysis this bias is accepted and the test results from the present test series are compared with the formula as proposed by Van der Meer (CUR, 1991).

\subsection{Quantitative analysis}

For this analysis a relation between the stability number $H_{s} / \Delta D_{n 50}$ and $h_{l} / h_{m}$ is supposed. The damage level $\mathrm{N}_{\mathrm{od}}$ is introduced in the relation as was proposed before this:

$$
\mathrm{H}_{\mathrm{s}} / \Delta \mathrm{D}_{\mathrm{n} 50}=\text { function } * \mathrm{~N}_{\mathrm{od}}^{0.15}
$$

Now a relation is supposed between the stability number with the damage level and $h_{l} / h_{m}$. To determine this relation $H_{s} / \Delta D_{n 50} * N_{o d}^{-0.15}$ is plotted as a function of $h_{t} / h_{m}$ as can be seen in Figure 43. Through the points in this figure a power curve seems to be the best fit. Now a relation is supposed of the form:

$$
\mathrm{H}_{\mathrm{s}} / \Delta \mathrm{D}_{\mathrm{ns0}} * \mathrm{~N}_{\mathrm{od}}^{-0.15}=\mathrm{a} *\left(\mathrm{~h}_{\mathrm{t}} / \mathrm{h}_{\mathrm{m}}\right)^{\mathrm{b}}
$$

From a best fit through the points in Figure 43 it was determined that $a=6.5$ and $b=1.2$.

It must be noted that the scatter around the curve is large because of the bias introduced in the relation.

The total relation now becomes:

$$
\frac{H_{s}}{\Delta D_{n 50}} N_{o d}^{-0.15}=6.5 \frac{h_{t}}{h_{m}}
$$


Or arranged in a different way:

$$
\frac{H_{s}}{\Delta D_{n 50}}=6.5 \frac{h_{t}{ }^{1.2}}{h_{m}} N_{o d}^{0.15}
$$

The relation found here can be used for $0.4<\left(h_{1} / h_{m}\right)<0.9$.

As was seen in section 2 Van der Meer (CUR, 1991) also found a relation between $h_{l} / h_{m}$ and the stability number $\mathrm{H}_{s} / \Delta \mathrm{D}_{\mathrm{n} 50}$ :

$$
\frac{h_{t}}{h_{m}}=0.22{\frac{H_{s}}{\Delta D_{n 50}}}^{0.7}
$$

Or arranged in a different way with the damage level $\mathrm{N}_{\mathrm{od}}$ included in the formula:

$$
\frac{H_{s}}{\Delta D_{n 50}}=7.8{\frac{h_{t}}{h_{m}}}^{1.43} N_{o d}^{0.15}
$$

Because the damage level is not included in the relation by van der Meer it is assumed here that for the damage level $\mathrm{N}_{\mathrm{od}}$ the value 2 can be used.

The value 2 for the damage level seems appropriate when the suggested damage levels in the present study are reviewed with $\mathrm{N}_{\mathrm{od}}=2$ as a design criteria (acceptable damage) $\mathrm{N}_{\mathrm{od}}=2$ seems a correct value for a stable toe structure as suggested by van der Meer which is based on acceptable damage (3-10\%).

When the value of $\mathrm{N}_{\mathrm{od}}=2$ is introduced in the relation of Van der Meer the relation becomes:

$$
\frac{H_{g}}{\Delta D_{n 50}}=8.7{\frac{h_{t}}{h_{m}}}^{1.43}
$$

This relation is plotted in Figure 44 along with the results from the present study.

When the suggested design curve by Van der Meer is compared with the design curve from the present study it can be concluded that for lower values of $h_{\mathrm{l}} / h_{\mathrm{m}}$ the values of the two curves agree well. For higher values of $h_{h} / h_{m}$ the difference between the two curves increases although they show the same curve shape, this is caused by the difference in the power used of 1.43 instead of 1.2 .

This means that the trend is the same for both curves and seems to be correct. Only the values of the curves are different.

The differences between the two relations could be explained by the differences between the two data sets used for the analysis.

Van der Meer has only used depth limited situations

(so $\mathrm{H}_{\mathrm{s}} / \mathrm{h}_{\mathrm{m}}=0.5$ ), in the present analysis data is also used from not depth limited situations.

Van der Meer has used tests with foreshores which were not very steep. The present tests were performed with a foreshore of 1:20; so a relatively steep foreshore.

Also the way the damage is determined could be different for both data sets which will result in different values and relations when the damage is included in the relation.

The value of the damage level chosen here for the relation of Van der Meer $\left(\mathrm{N}_{o d}=2\right)$ is of influence to the position of the curve of van der Meer and it could be examined what value 
of $\mathrm{N}_{o d}$ corresponds with test results used for the relation suggested by Van der Meer.

It can be concluded from this analysis that although the stability number is not the correct parameter to fully describe toe stability a relation can be found when the stability number is used in that way. The relation found here shows the same trend as existing design criteria but a large scatter must be accepted.

\subsection{Further quantitative analysis}

As was shown before the stability number $H_{s} / \Delta D_{n 50}$ is not the parameter to fully describe toe stability.

Because the relation between the shallow water significant wave height $\mathrm{H}_{s}$ and the stone diameter $D_{n 50}$ is linear but not through the origin, a bias is introduced in the relation found.

To compensate for this bias one of the parameters in the stability number must be used again in a relation with the stability number.

This means that the shallow water significant wave height $\mathrm{H}_{\mathrm{s}}$ or the nominal stone diameter $D_{n 50}$ should be used again.

To make an analysis with dimensionless parameters possible $\mathrm{H}_{3}$ or $\mathrm{D}_{\mathrm{n} 50}$ should be divided by a parameter with the dimension of length.

The parameter that is typical for the toe structure is the depth above the toe $h_{t}$ so this parameter seems to be the best parameter to obtain a dimensionless parameter with the significant wave height or the stone diameter.

In the Figures $45 a, 46 a$ and $47 a H_{s} / \Delta D_{n 50} * N_{o d}^{-0.15}$ is plotted for $h_{r} / D_{n 50}$ and in the figures $45 \mathrm{~b}, 46 \mathrm{~b}$ and $47 \mathrm{~b} \mathrm{H}_{s} / \Delta \mathrm{D}_{\mathrm{n} 50} * \mathrm{~N}_{\mathrm{od}}^{-0.15}$ is shown for $h_{\mathrm{r}} / \mathrm{H}_{\mathrm{s}}$ for the water depths $\mathrm{h}$ and the toe heights $h_{m}-h_{t}$ tested.

For the shallower water depth $h=0.7 \mathrm{~m}$ in Figure 45 for both $h_{4} / D_{n 50}$ and $h_{4} / H_{s}$ a clear trend can be found, so both could be used. But for the larger water depths of $0.8 \mathrm{~m}$ and $0.9 \mathrm{~m}$ in the figures $47 \mathrm{~b}$ and $48 \mathrm{~b}$ it can be seen that for $h_{l} / \mathrm{H}_{s}$ and smaller toe heights $h_{m}-h_{l}$ of $0.08 \mathrm{~m}$ the trend is no longer clear. For $h_{\imath} / D_{n 50}$ in the Figures $46 a$ and $47 a$ for larger water depths and all toe heights a clear trend is still visible.

Because this trend is clear for all combinations of water depths and toe heights for $h_{t} / D_{n s 0}$ and not for $h_{1} / H_{s}, h_{l} / D_{n s 0}$ is chosen as the dimensionless parameter for the further quantitative analysis with the stability number.

$h_{t} / D_{n 50}$ also has a physical meaning as the depth of the toe in number of stones.

For the quantitative analysis of the results of the present tests $H_{\mathrm{s}} / \Delta \mathrm{D}_{\mathrm{n} 50} * \mathrm{~N}_{\mathrm{od}}{ }^{-0.15}$ is plotted for $\mathrm{h}_{\mathrm{l}} / \mathrm{D}_{\mathrm{n} 50}$ in Figure 48.

Through the points a straight line seems the best fit.

Now a relation is supposed of the form:

$$
\mathrm{H}_{\mathrm{s}} / \Delta \mathrm{D}_{\mathrm{n} 50} * \mathrm{~N}_{\mathrm{od}}^{-0.15}=\mathrm{a} * \mathrm{~h}_{\mathrm{l}} / \mathrm{D}_{\mathrm{n} 50}+\mathrm{b}
$$

From a best fit through the points in Figure 48 it is determined that $a=0.24$ and $b=1.6$.

Now the total relation becomes:

$$
\frac{H_{s}}{\Delta D_{n 50}}=\left(0.24 \frac{h_{t}}{D_{n 50}}+1.6\right) N_{o d}^{0.15}
$$


This relation is based on the smoothed data set from the present test series with fixed damage levels as can be found in Table 3. The original test results from the present test series as can be found in Table 2 can be used to verify the found relation.

In Figure $50 \mathrm{H}_{\mathrm{s}} / \Delta \mathrm{D}_{\mathrm{n} 50} * \mathrm{~N}_{\mathrm{od}}^{-0.15}$ is plotted for $\mathrm{h}_{\mathrm{f}} / \mathrm{D}_{\mathrm{n} 50}$ like was done with the smoothed data set in Figure 48 but now with the original test results.

It can be seen that the relation found in the present study (equation 4) is correct with the original test results as well. The scatter around the found relation is larger with the original test results (Figure 50) than with the smoothed data set (Figure 48). It is clear that in the smoothed data set the extremes are filtered and a smoother result is obtained with less scatter around the found relation than if the original test results are used.

For values of $h_{l} / D_{n 50}$ lower than 0 the toe structure would become an armour layer. In the present found relation a value for the stability number of 1.6 for the toe structure is suggested for $h_{\mathrm{t}} / \mathrm{D}_{\mathrm{n} 50}=0$. If a stability formula for the armour layer is considered (Cur, 1991, page 266) like the formula of Van der Meer (1989) it can be seen that for comparable circumstances (1:1.5 slope, $\mathrm{s}_{\mathrm{op}}=0.02-0.04$ and 1000 waves) a stability number of 1.7 can be found for the armour layer. From this it can be concluded that the relation for toe stability should not go through the origin but for lower values of $h_{t} / D_{n 50}$ the stability number should be approximately 1.7 in the present relation a value of 1.6 is suggested. It seems that the relations for toe stability and armour layer stability agree well.

Some of the results in Figure 52 seem to be systematically lower than the found relation. This is clearly visible for $h_{1} / D_{n 50}=10,11$ and 14 . The test results for these values are all lower than the values obtained with the found relation.

It was thought that the deviation around the found relation would have a trend of a lower value for depth limited situations.

To determine if the deviation around the found relation is systematic the relation found (equation 4) is plotted for the relative water depth $h_{m} / H_{s}$ in Figure 49 for the smoothed data set and in Figure 51 for the original data set.

It can be clearly seen in both figures that with a decreasing relative water depth the values of the relation from the present study increase.

This strengthens the idea that the depth limited test situations give a lower value than the found relation. The use of the $2 \%$ wave height at the structure could improve the reliability of the relation because the influence of a depth limited situation is considered better with the $2 \%$ wave height.

In Figure 11 the ratio $\mathrm{H}_{2 \%} / 1.4 \mathrm{H}_{\mathrm{s}}$ is shown as a function of the relative water depth $\mathrm{h}_{\mathrm{m}} / \mathrm{H}_{\mathrm{s}}$. A clear trend is shown where the ratio $\mathrm{H}_{2 \%} / 1.4 \mathrm{H}_{s}$ decreases with decreasing relative water depth.

From this it could be concluded that if the two effects are combined the total relation would be more accurate. So with a decreasing relative water depth $\mathrm{H}_{2 \%} / 1.4 \mathrm{H}_{\mathrm{s}}$ decreases but the value of the found relation (equation 4 ) increases, the new result using the $2 \%$ wave height at the structure in stead of the significant wave height at the structure would be better than the relation found before (formula 4 ).

To analyse the effect of using the $2 \%$ wave height in Figure $52 \mathrm{H}_{2 \%} / \Delta \mathrm{D}_{\mathrm{n} 50} * \mathrm{~N}_{\mathrm{od}}{ }^{-0.15}$ is shown as a function of $h_{\mathrm{r}} / \mathrm{D}_{\mathrm{n} 50}$ like was done before with the significant wave height.

The $2 \%$ wave height is taken from the original test results from the present test series as can be found in Table 2 .

Again a straight line seems to be the best fit through the points. 
With a best fit the relation was determined to be:

$$
\frac{H_{2 *}}{\Delta D_{n 50}}=\left(0.34 \frac{h_{t}}{D_{n 50}}+2.2\right) N_{o d}^{0.15}
$$

It can be seen from Figure 52 that the scatter around the found relation (equation 5) is again very large, even larger than when the significant wave height was used in Figure 50.

Some improvement in accuracy seems to be achieved because when the values for $h_{1} / D_{n 50}=$ 10, 11 and 14 are considered again the values in Figure 52 seem to be closer to the found relation than in Figure 50. The deviation per test series is less, more series can be found around the average.

To verify if the expected improvement in accuracy is obtained the found relation with the $2 \%$ wave height (equation 5) is shown for the relative water depth $h_{m} / H_{s}$ in Figure 53.

It can be clearly seen that still the found relation (equation 5 ) decreases when the relative water depth increases.

This means that the expected gain in accuracy when the $2 \%$ wave height is used is not fully obtained in the present study although some improvement is present for individual test series.

The 2 found relations have a relation:

$$
\frac{H_{s}}{\Delta D_{n 50}}=\frac{H_{2 s} / 1.4}{\Delta D_{n 50}}=\left(0.24 \frac{h_{t}}{D_{n 50}}+1.6\right) N_{o d}^{0.15}
$$

In this it can be seen that ratio of $\mathrm{H}_{2 \%}=1.4 \mathrm{H}_{\mathrm{s}}$ is applicable in the found relations and the 2 relations seem reliable.

It can be concluded that the relation found when the significant wave height at the structure is used (equation 4) is sufficiently accurate but a deviation is present which should be corrected when the $2 \%$ wave height is used. The relation found in the present study (equation 5) with the $2 \%$ wave height does not give the expected improvement, although some improvement is visible. 


\section{Comparison of the relation from the present study with existing test results}

\subsection{Introduction}

The relation found in the present study can be compared with test results from other existing test series to review the reliability of the relation.

The results of other tests were collected from test reports of Delft Hydraulics.

First a literature and reports study on breakwaters was performed for the MAST European Research Project.

Some of the tests from that reports study were selected to use for an analysis of the reliability of the relation found in the present study.

First the study for the MAST research project will be presented and than the relation found in the present study will be compared with existing test results.

\subsection{The MAST research project}

A part of this Master thesis was a literature and reports study on breakwaters.

This was done as a part of the MAST G6-S project III R2, stability of breakwater singular points, which include roundheads, junctions, bends, toe and rock berms (Gerding, 1992).

It is a desk study based on available reports on site specific breakwaters studies performed at Delft Hydraulics. The aim by the end of the MAST study is to write preliminary guidelines on these subjects to be included in the planned "European Coastal Engineering Handbook".

For this study the contents of about 500 reports was reviewed

from the library of Delft Hydraulics in De Voorst and the personal archives at Delft Hydraulics.

From these reports 60 were found to contain relevant information on breakwater singular points.

In order to classify these reports the following criteria were used:

- What is the main purpose of the report; to investigate stability, wave overtopping, wave run-up or reflection.

- What kind of model tests have been run; 3D or 2D, head or trunk sections.

- How well described are the environmental conditions and structural geometry for which model tests have been run.

- Did damage occur and is it well described.

- What are the variations in the model tests that have been run.

Finally 10 studies were selected to set up the database.

They were selected after considering:

- Environmental conditions and structural geometry well described.

- Damage well described.

- Equal amount of 2D and 3D tests.

- Equal amount of tests with head and trunk sections.

- Several types of armour units. 
The most important parameters of the reports and tests were put into a database.

The content of this database can be found in Delft Hydraulics Report no. H 1351: MAST G6-S. Project III R2 Rubble mound breakwaters. Stability of breakwater singular points 1992.

The data collected in this study have been submitted to the projectleader for further analysis.

\subsection{Comparison of the result of the present study with existing test results}

From the database found for the MAST research project study 5 test series were selected to use for comparison with the relation found for toe stability in the present study.

These 5 test series were selected because the damage to the toe structure was well described. This means that the number of removed stones from the toe structure must be given so later the damage level $\mathrm{N}_{\alpha d}$ could be determined and the comparison with the result of the present study including the damage level $\mathrm{N}_{\mathrm{od}}$ could be done in the correct way.

The most important parameters from these 5 test series can be found in Table 4 .

The relation found in the present study is:

$$
\frac{H_{s}}{\Delta D_{n 50}}=\left(0.24 \frac{h_{t}}{D_{n 50}}+1.6\right) N_{\infty d}^{0.15}
$$

In Figure 54 this relation is plotted. In the same figure the values of $H_{s} / \Delta D_{n 50} * N_{o d}{ }^{-0.15}$ are plotted for $h_{t} / D_{n 50}$ from the existing test results.

The trend of the relation from the present study and the trend of the points of the existing test results is the same but the values of the existing test result are higher than the relation from the present study.

The results from existing tests also contain very low damage levels $\mathrm{N}_{\mathrm{od}}$, some very close to 0 as can be seen in Table 4. The lowest suggested damage level in this study is $N_{o d}=0.5$ so very low damage levels could introduce a bias.

From this the idea developed that the results would agree better if only the existing test results with a damage level of 0.5 or higher were considered.

In Figure 55 the values of $\mathrm{H}_{\mathrm{s}} / \Delta \mathrm{D}_{\mathrm{n} 50} * \mathrm{~N}_{\mathrm{od}}{ }^{-0.15}$ are again plotted for $\mathrm{h}_{\mathrm{l}} / \mathrm{D}_{\mathrm{n} 50}$ but now only the values with $\mathrm{N}_{\mathrm{od}}>0.5$ are plotted.

It can be seen that test series 5 only contained values with $\mathrm{N}_{\mathrm{od}}<0.5$ and does not return in Figure 55.

The points from existing test results in the figure again show the same trend as the relation found in the present study and again the values from existing tests are higher although less than in Figure 54 with all values of $N_{o d}$. The scatter of the points from the existing tests is less in Figure 54 than in Figure 55.

The values from the existing test results seem to be systematically higher than the relation found in the present study.

This means that with the relation found in the present study safer toe structures would be designed than was done with the existing test results. This can be seen in the Figures 54 and 55 because the relation found in the present study gives a lower significant wave height $H_{s}$ or a larger stone diameter $D_{n 50}$ for the same damage level than is found in the existing test results, so a safer toe structure is designed.

An explanation for this difference may be that the existing tests were performed with gentler foreshores than the present tests. 
In the test series for the present study a steep foreshore of 1:20 was used; in the existing tests gentler foreshores were used of 1:50 and 1:100.

Another explanation may be that the damage could be determined in a different way in the present study than in the existing tests. This could lead to different results, but in the existing test reports no details are given of how the damage was determined so comparison is not possible.

It can be concluded that the relation found in the present study and the results from existing tests show the same trend but the relation found in the present study gives slightly heavier results than the results from existing tests. 


\section{Discarded parameters}

In the present test series a few parameters were not taken into account for practical reasons. Firstly the shape of the foreshore is not varied in the present test series.

The shape of the foreshore is of influence to the stability of the toe structure. Although it is tried in the present study to include this influence by introducing the $2 \%$ wave height in the relation it is recommended to investigate the precise influence of the foreshore on toe stability.

The shape of the breakwater itself is another parameter that was not considered here.

Especially the steepness of the armour layer will have an influence on the damage to the toe structure. A steeper armour layer will probably lead to more damage than a less steep armour layer, due to deeper rundown of waves.

The last parameter discarded in the present study is the stone mass density. Although it is expected that a higher mass density gives a larger toe stability this has only been proven for the armour layer and not for the toe structure. The mass density can be found in the stability number in the suggested formula. It has not been proven that the influence of the mass density is reproduced in the correct way by the suggested formula.

Variation of the stone mass density could support or denounce the choice of $h_{l} / D_{n 50}$ instead of $h_{4} / H_{s}$.

It is recommended to investigate the influence of the parameters that were discarded in the present study on toe stability. 


\section{Validity of formulas}

The suggested design relation is when the significant wave height $\mathrm{H}_{s}$ is used:

$$
\frac{H_{s}}{\Delta D_{n 50}}=\left(0.24 \frac{h_{t}}{D_{n 50}}+1.6\right) N_{o d}^{0.15}
$$

If the $2 \%$ wave height is available the design relation can be used:

$$
\frac{H_{2 t}}{\Delta D_{n 50}}=\left(0.34 \frac{h_{t}}{D_{n 50}}+2.2\right) N_{o d}^{0.15}
$$

For the design of the toe structure a damage level is suggested of :

$\mathrm{N}_{o d}=0.5$ if hardly any damage to the toe structure is required

$\mathrm{N}_{\mathrm{od}}=2$ as a normal design damage value with acceptable damage to the toe structure.

Both relations found in the present study can be used if :

$$
\begin{aligned}
0.4 & <\mathrm{h}_{\mathrm{h}} / \mathrm{h}_{\mathrm{m}}<0.9 \\
3 & <\mathrm{h}_{\mathrm{l}} / \mathrm{D}_{\mathrm{n} 50}<25
\end{aligned}
$$




\section{References}

Brebner,B and Donnelly,P, (1962)

Laboratory study of rubble foundations for vertical breakwaters.

Queen's University, Engineer Report No. 23

CIAD, (1985)

Computer aided evaluation of the reliability of a breakwater design.

Report of the CIAD project group on breakwaters.

CUR/CIRIA, (1991)

Manual on the use of rock in coastal and shoreline engineering.

CUR report 154/CIRIA Special Publication 83

Daemen,I.F.R.,(1991)

Wave transmission at low crested structures.

Master thesis, Delft University of Technology.

Gerding, E.,(1992)

MAST G6-S Project III R2, Rubble mound breakwaters, Stability of breakwater singular points.

Delft Hydraulics report no. H 1351.

Gravesen,H and Sørensen,T, (1977)

Stability of rubble mound breakwaters.

Proc. 24th Int. Navigation Congress.

Massie,W.W.(editor),(1986)

Coastal Engineering (Vol.III, breakwater design).

Lecture notes F5, Delft University of Technology.

Meer,J.W. van der (1989)

Rock slopes and gravel beaches under wave attack.

Dissertation, Delft University of Technology.

Schiereck,G.J., (1992)

Introduction to bed, bank, shore protection.

Lecture notes F4, Delft University of Technology:

SPM, (1984)

Shore Protection Manual.

US Army Coastal Engineering Centre. 


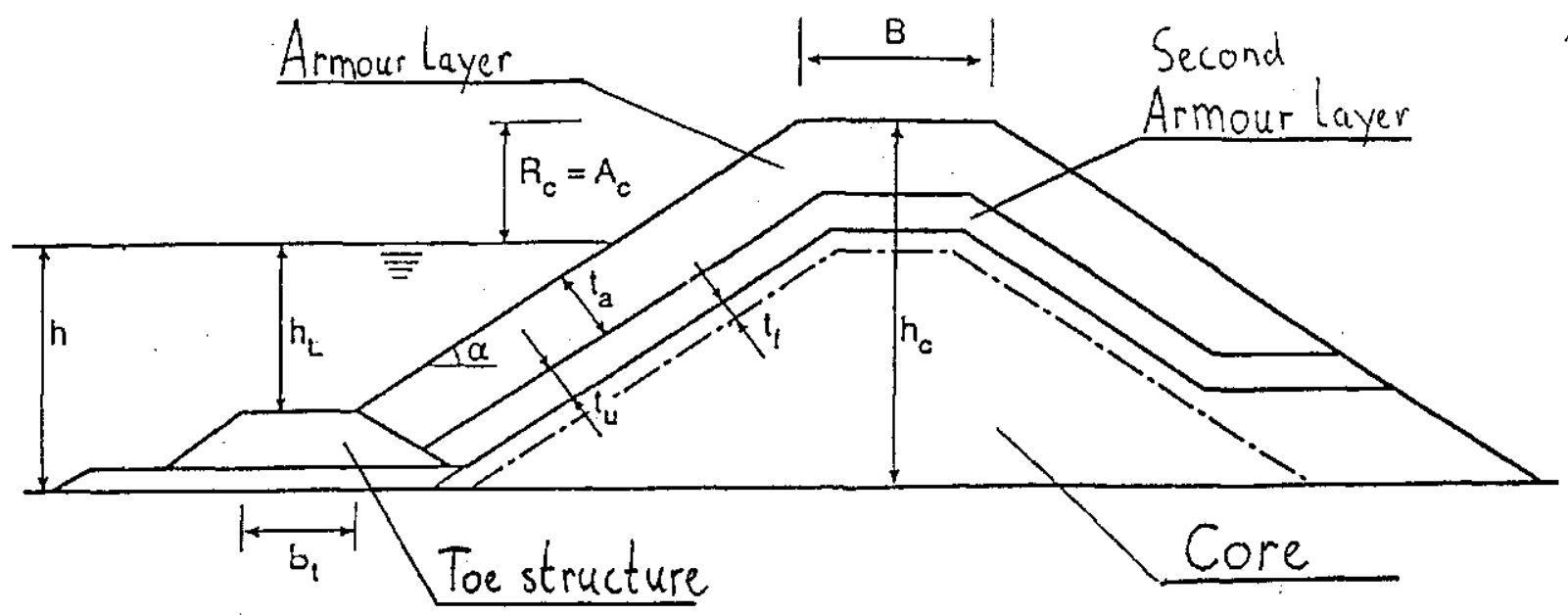

Figure 1 example of breakwater cross section

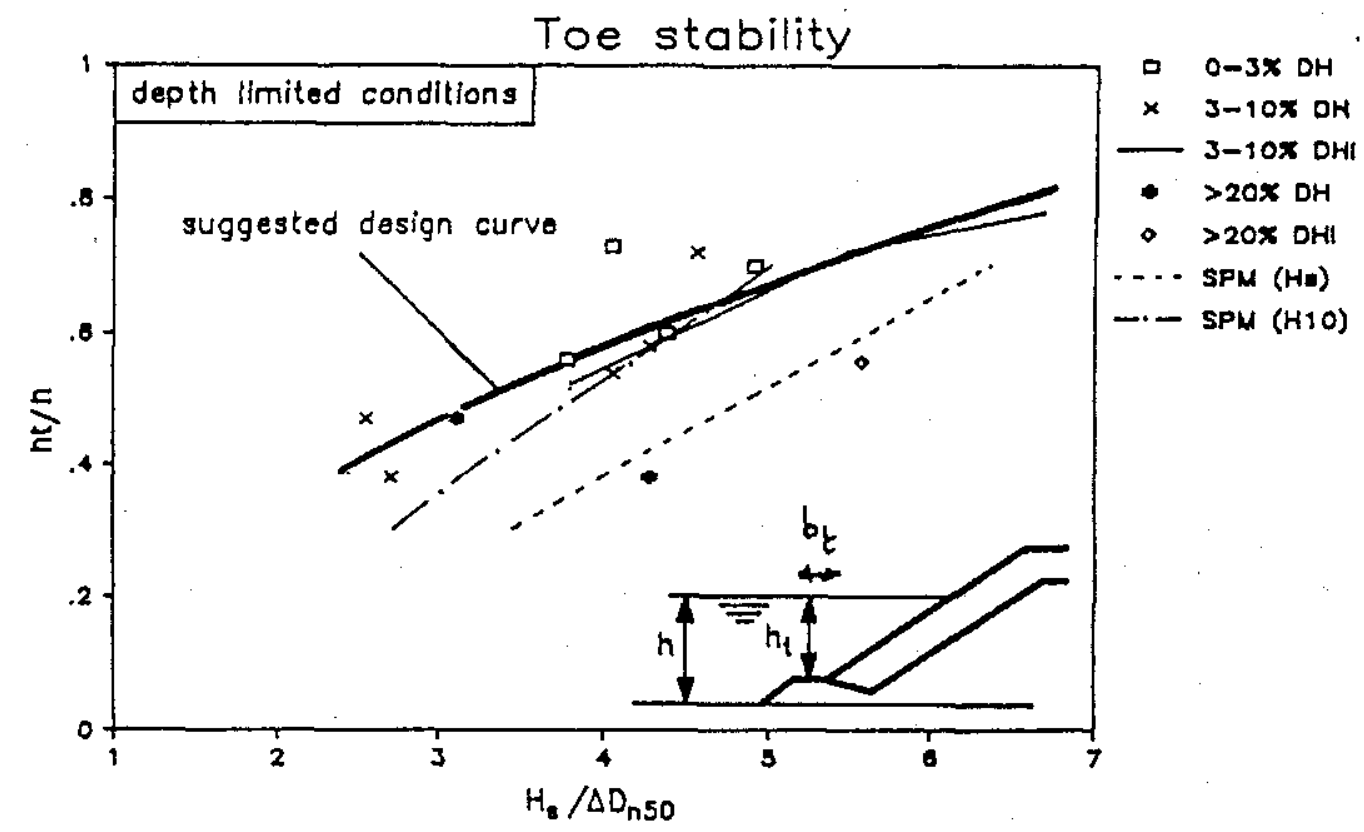

Figure 2 proposed design curve for toe stability by van der Meer (CUR, 1991)

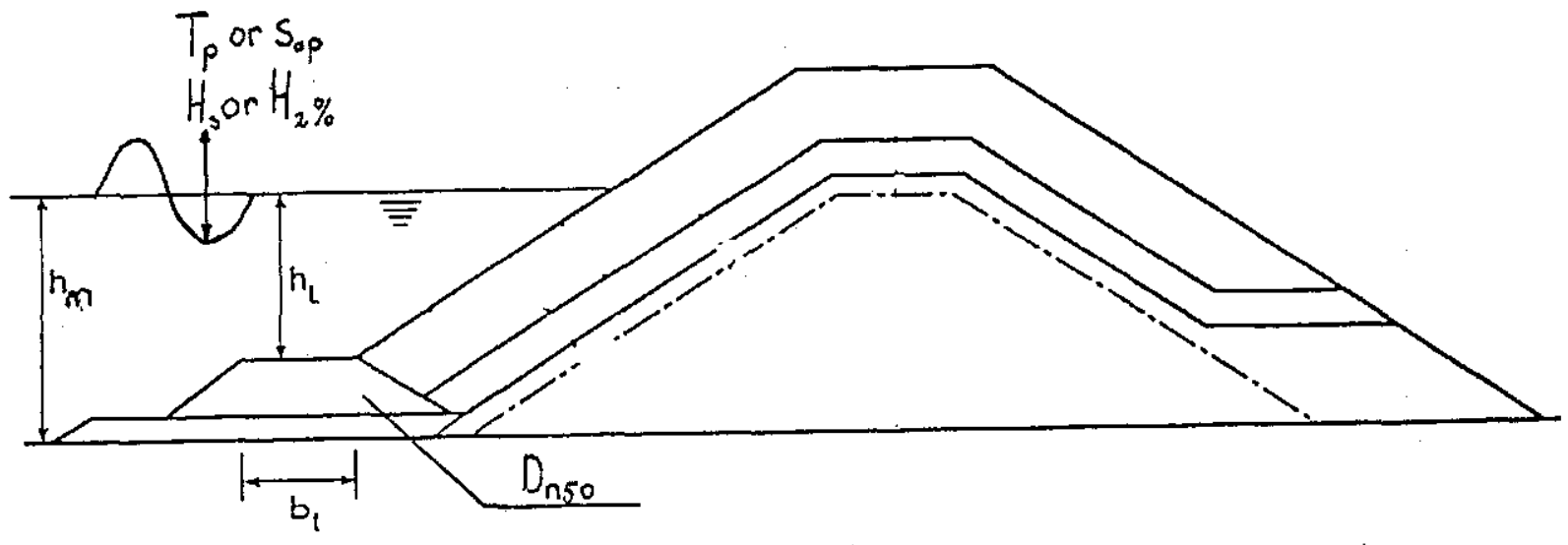

Figure 3 governing parameters for toe stability 


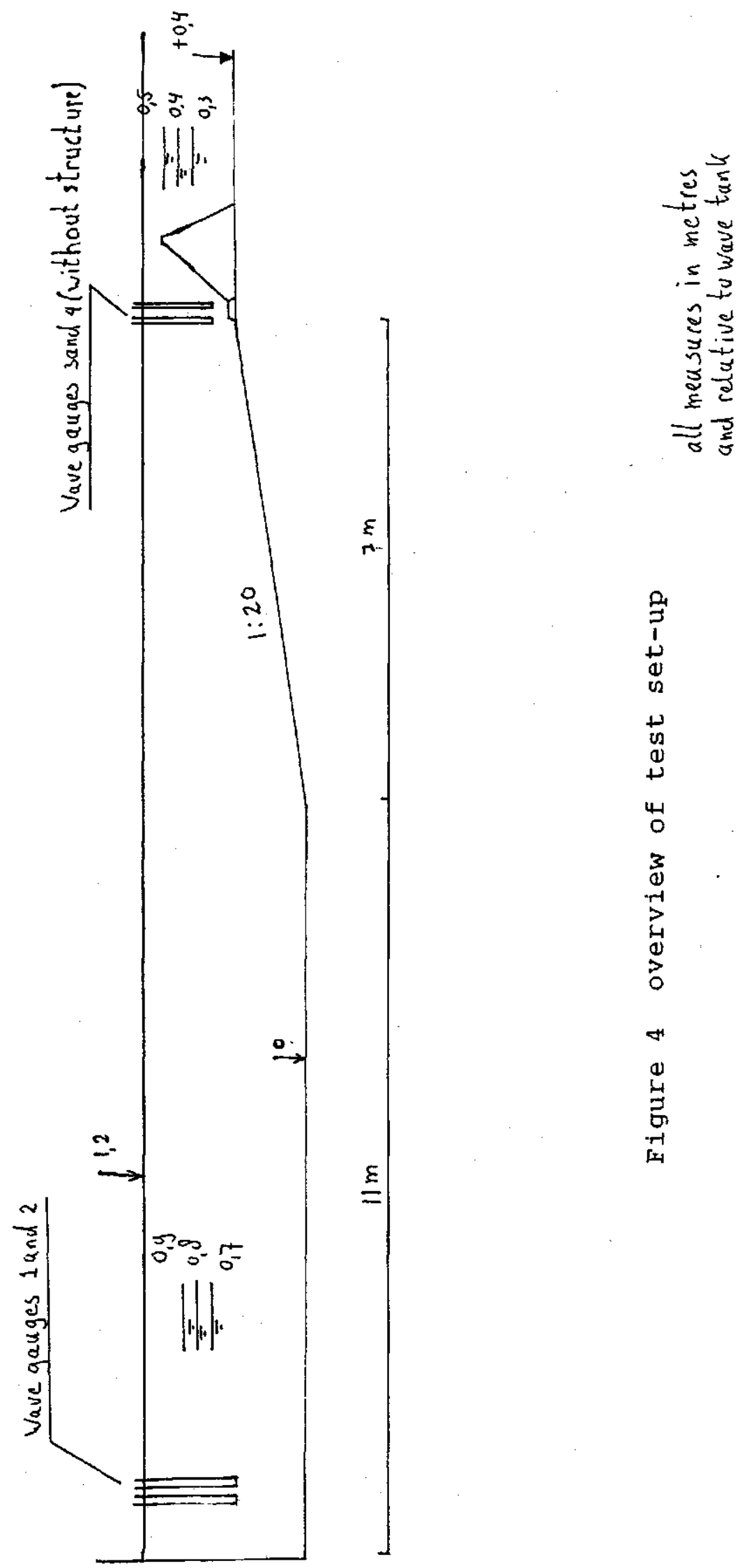




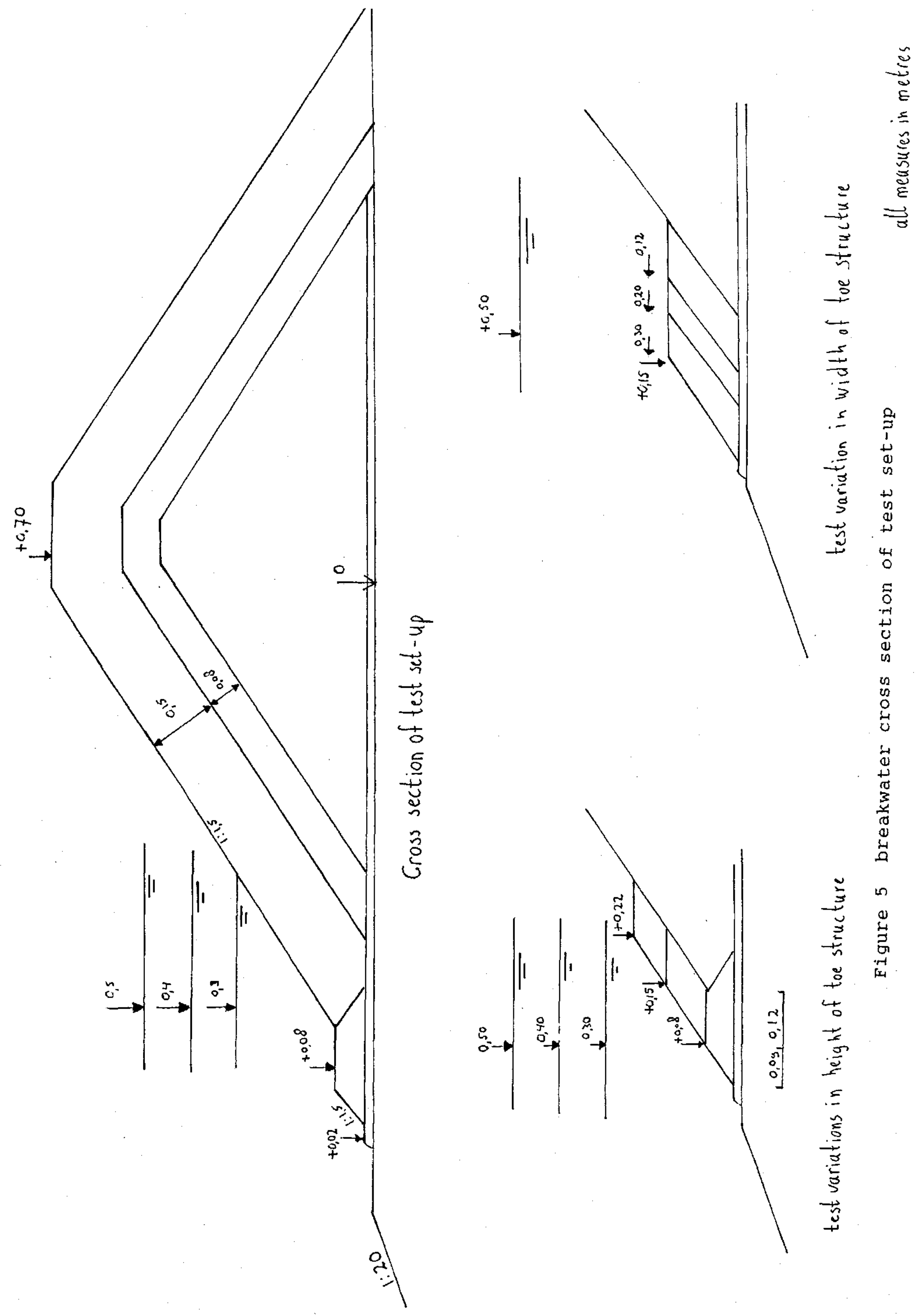


influence of waterdepth on significant wave height

$S_{00}=0.02$

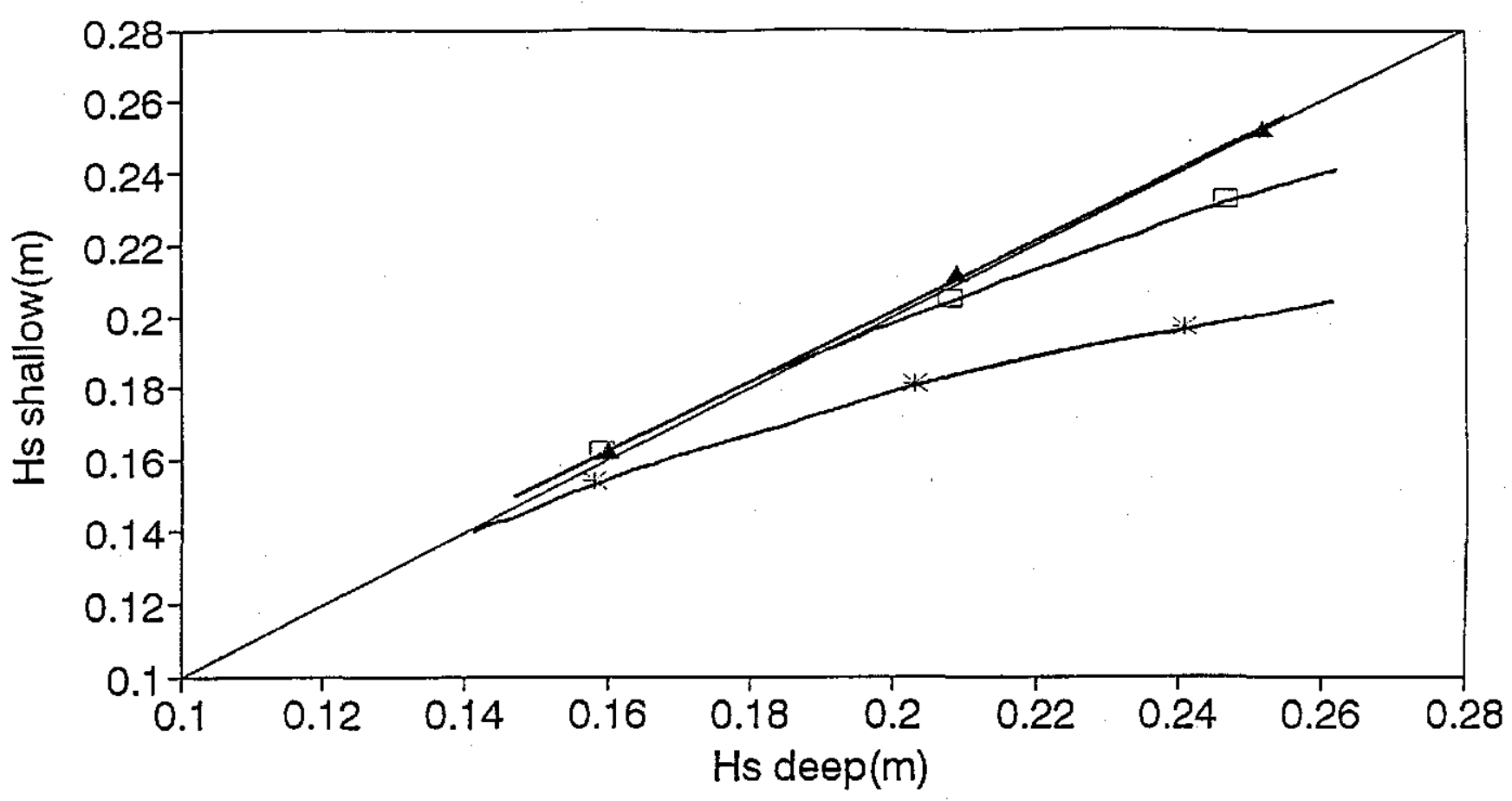

* $\mathrm{h}=0.7 \mathrm{~m} \square \mathrm{h}=0.8 \mathrm{~m} \Delta \mathrm{h}=0.9 \mathrm{~m}$

$S_{o p}=0.04$

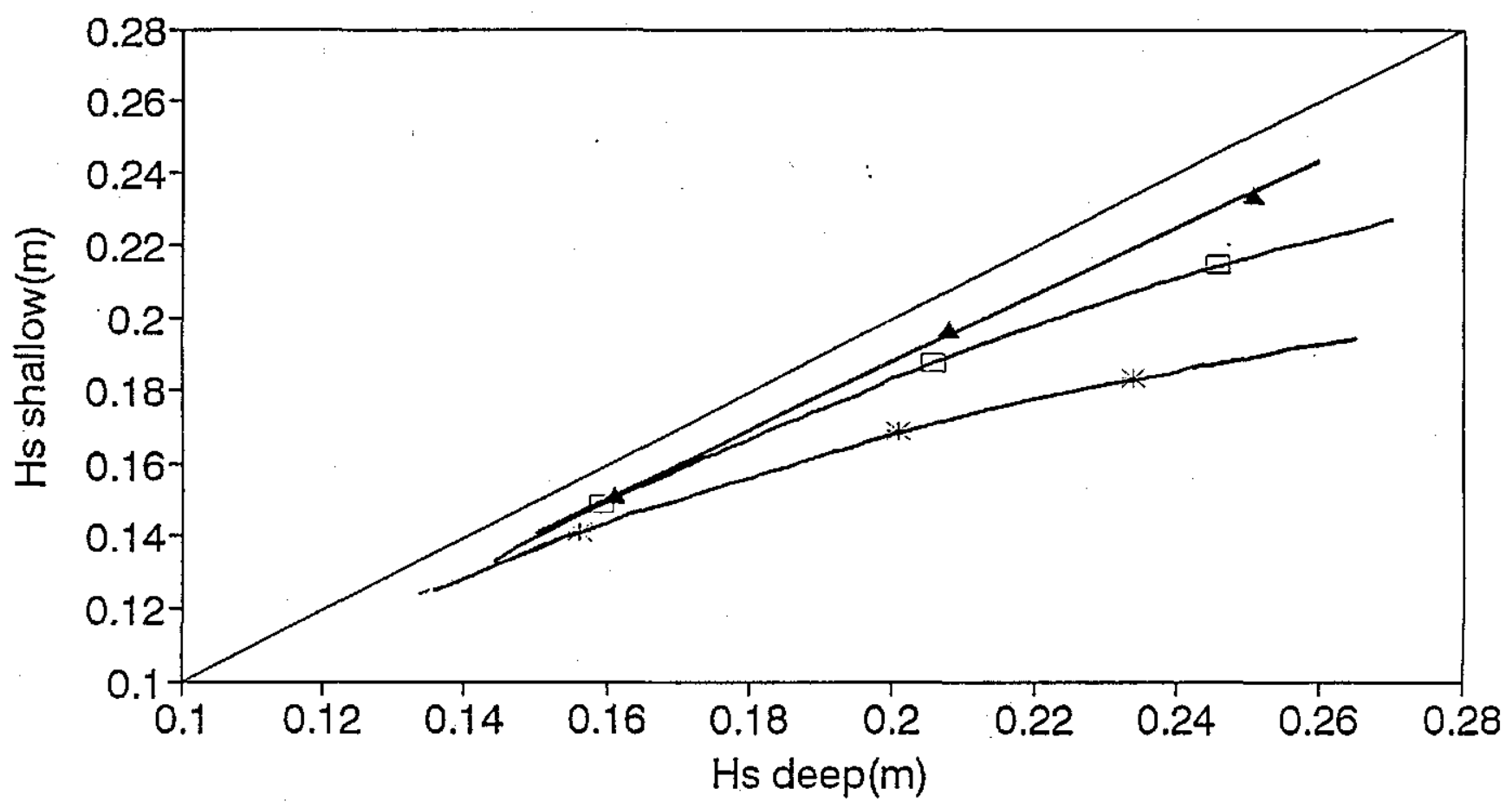

* $h=0.7 m$ ㅁ $h=0.8 m \quad \Delta \quad h=0.9 m$ 
influence of waterdepth on $2^{\circ}$ wave height

$$
s_{o p}=0.02
$$

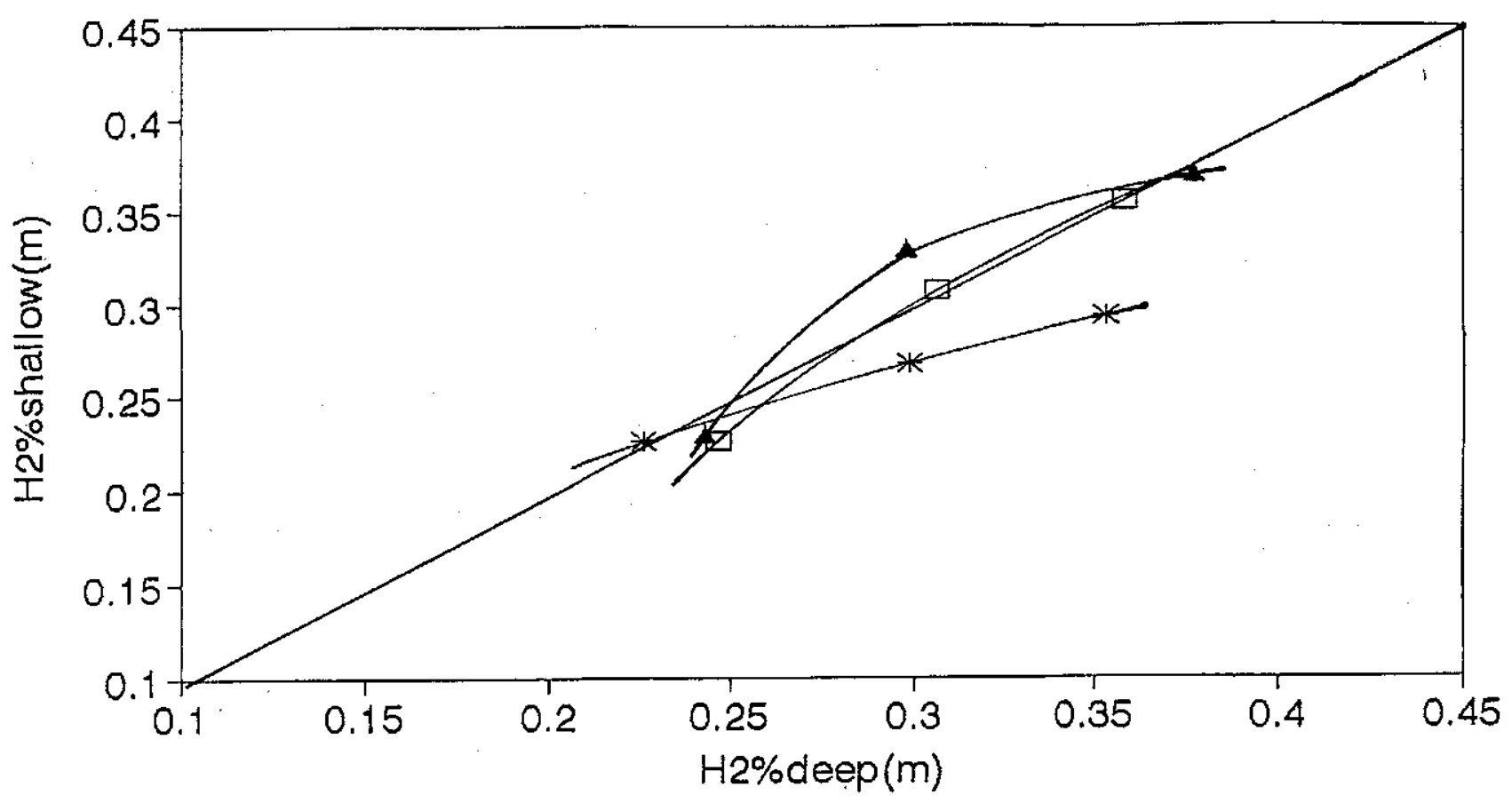

$S_{o p}=0.04$

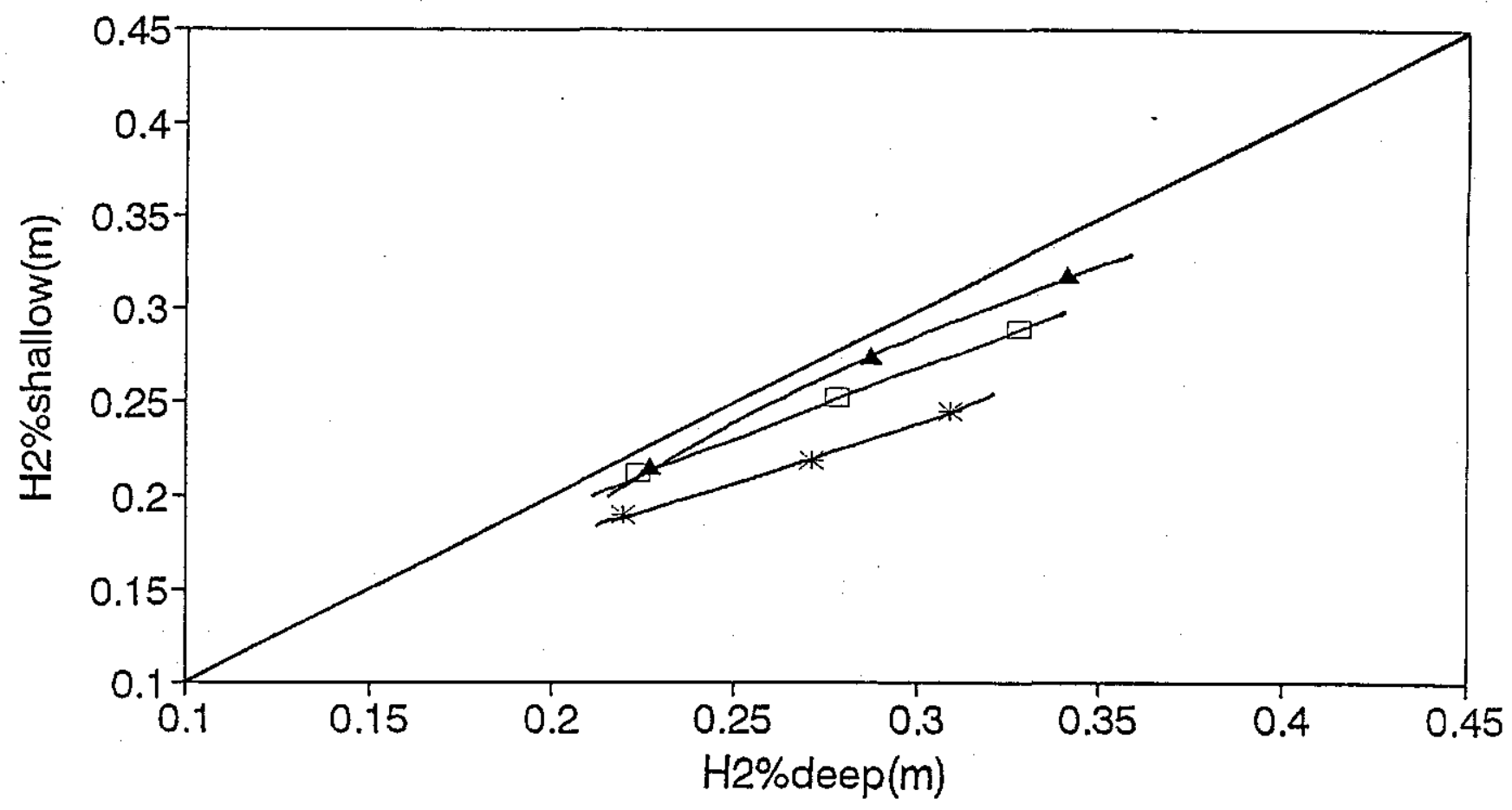

* $h=0.7 m$ 口 $h=0.8 m \Delta h=0.9 m$ 


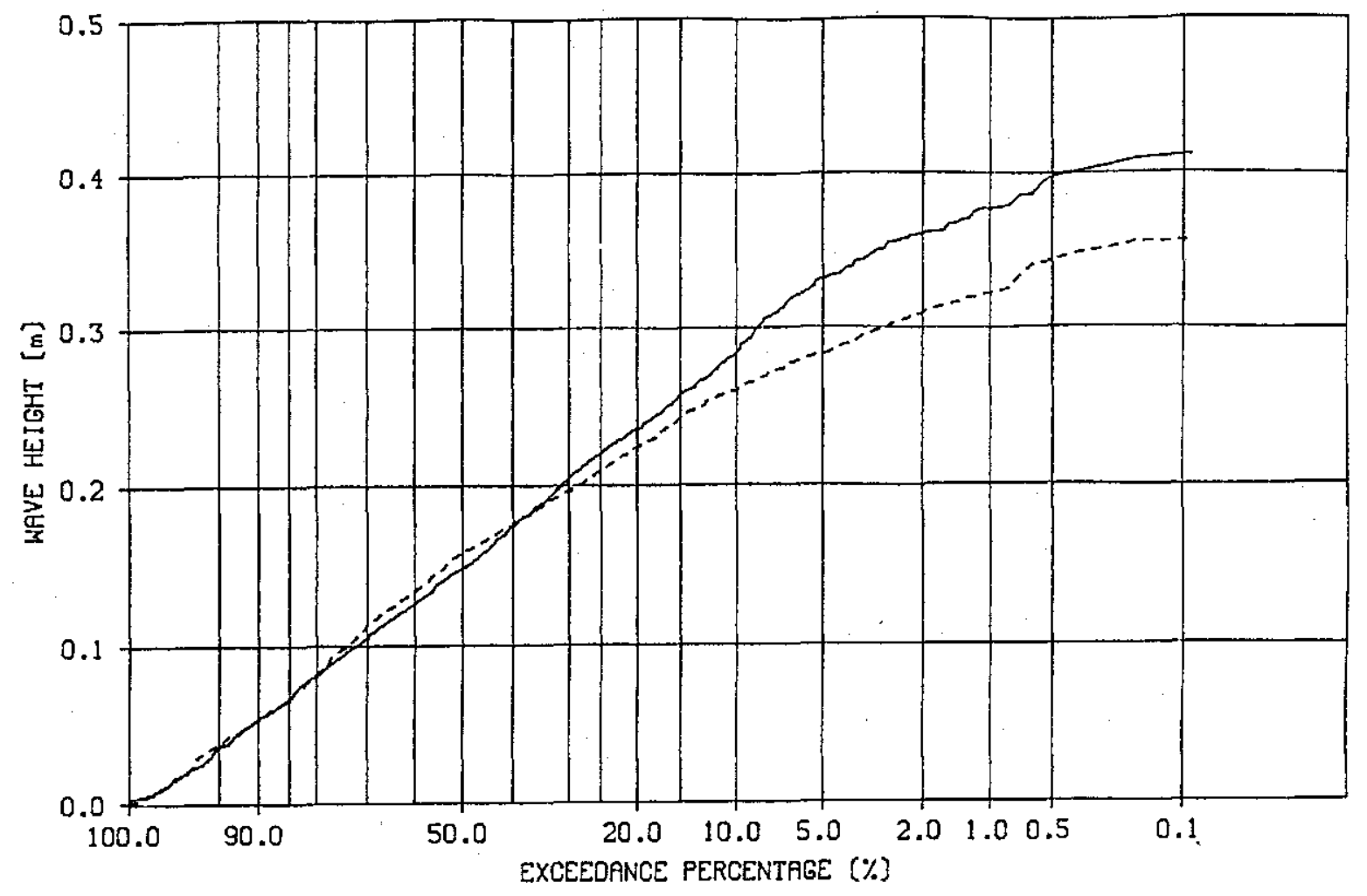

GHM 1

GHM 3

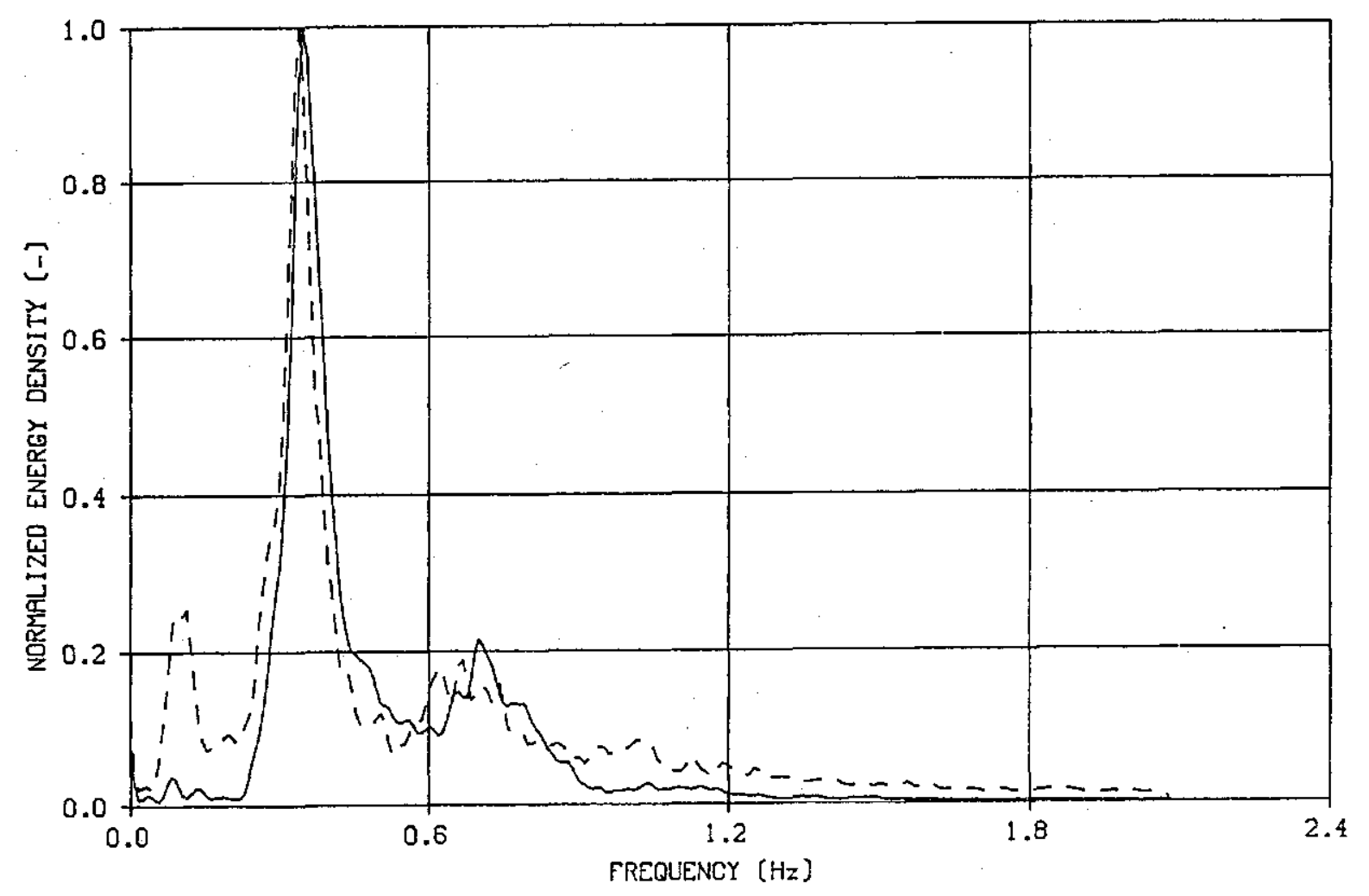

EXCEEDANCE CURVES AND \begin{tabular}{l|l}
2008 & $h=0.7 \mathrm{~m}$
\end{tabular}

ENERGY DENSITY SPECTRA 


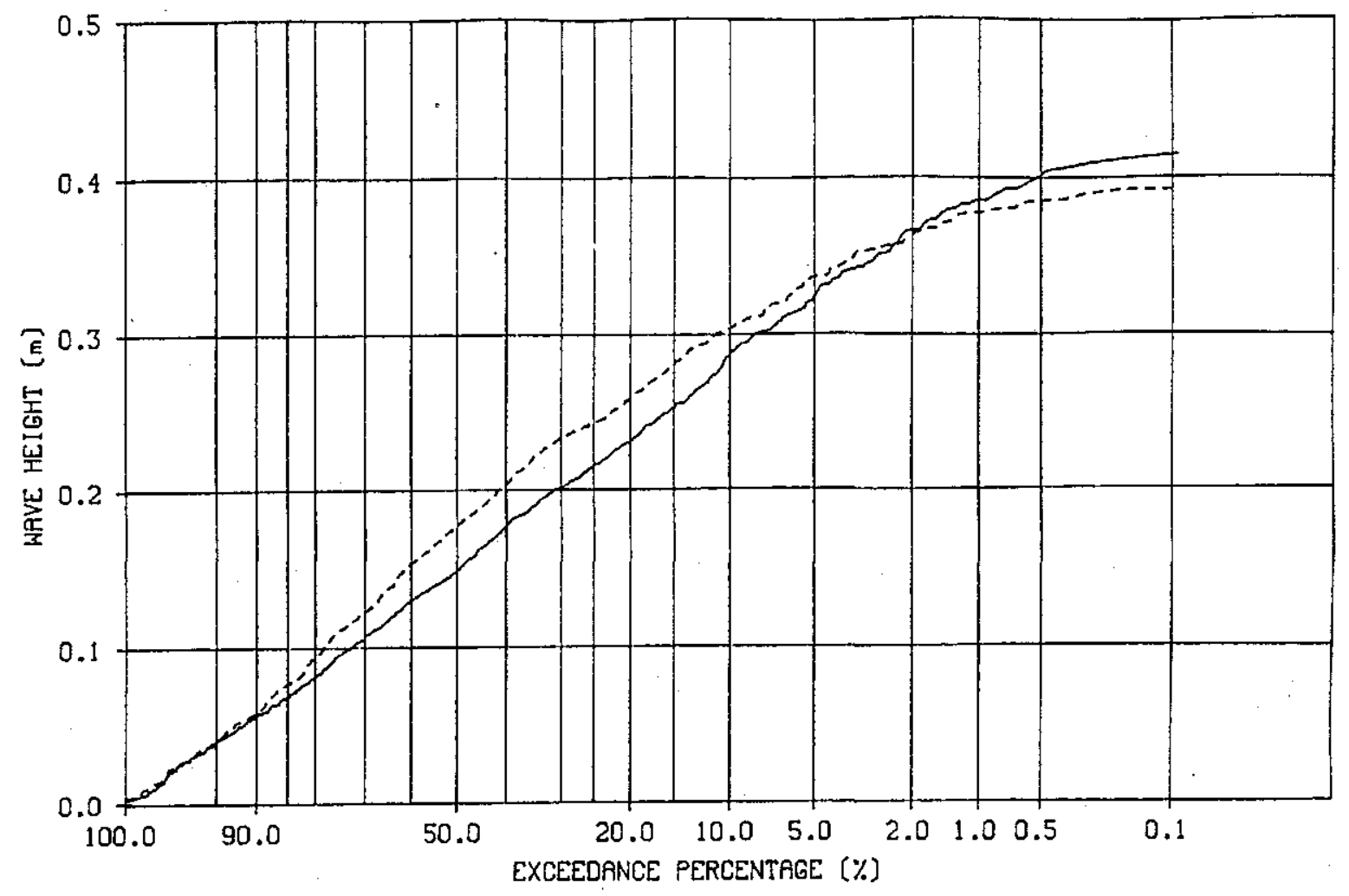

GHM 1

GHM 3

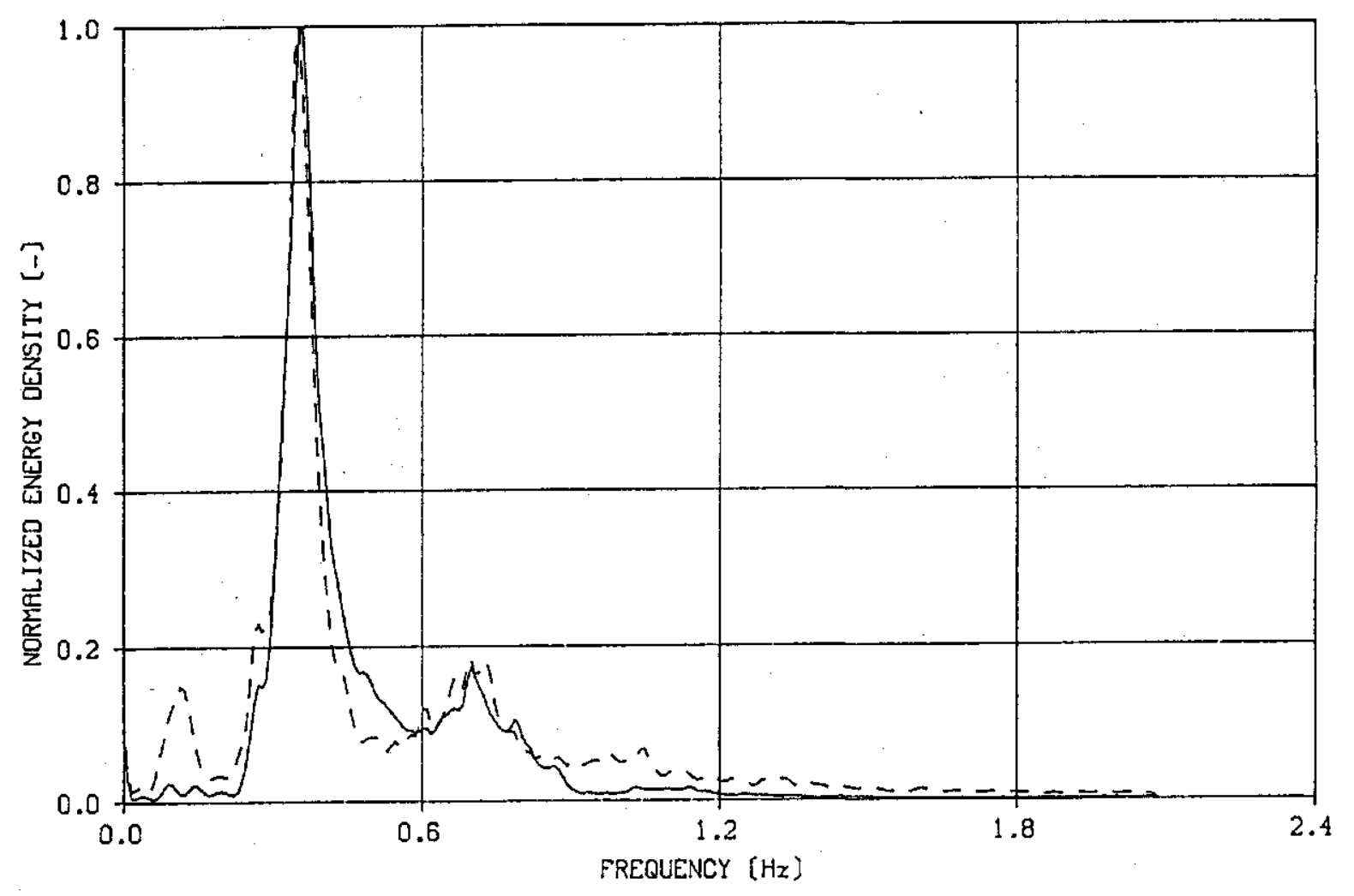

EXCEEDANCE CURVES AND

ENERGY DENSITY SPECTRA 


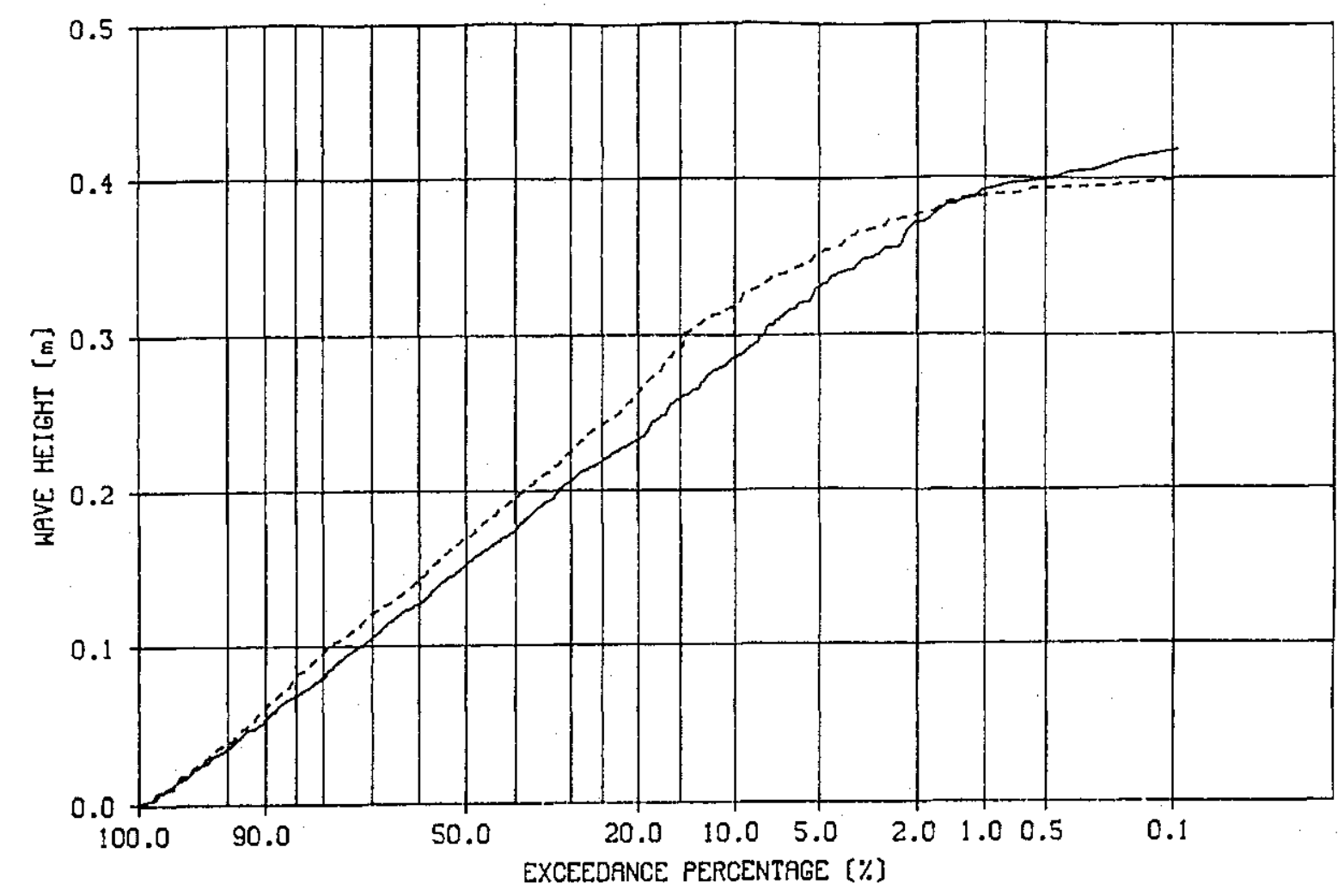

GHM 1

GHM 3

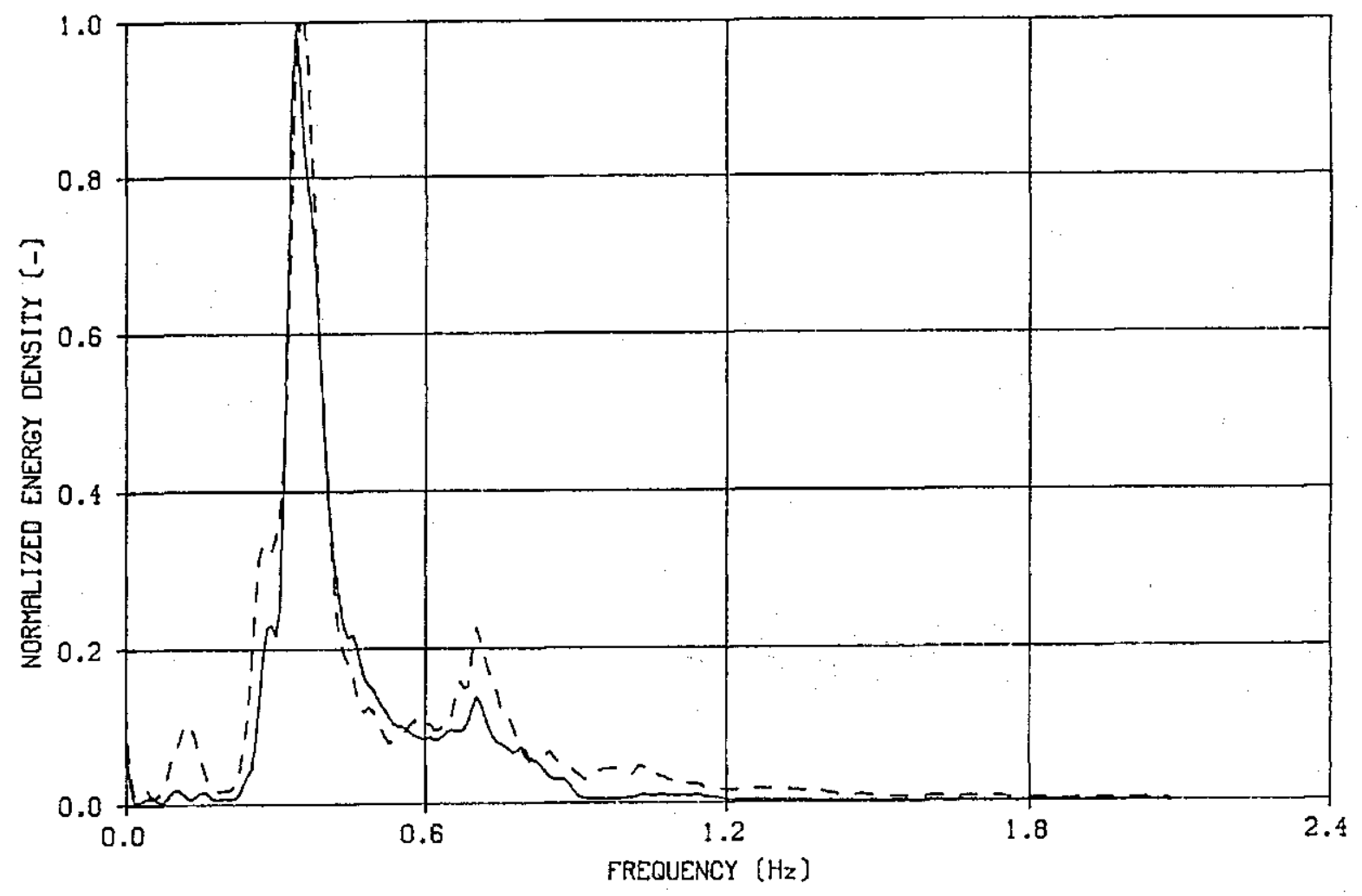

EXCEEDANCE CURVES AND

\begin{tabular}{l|l}
2022 & $h=0 . g m$
\end{tabular}

ENERGY DENSITY SPECTRA 
foreshore : 1:20

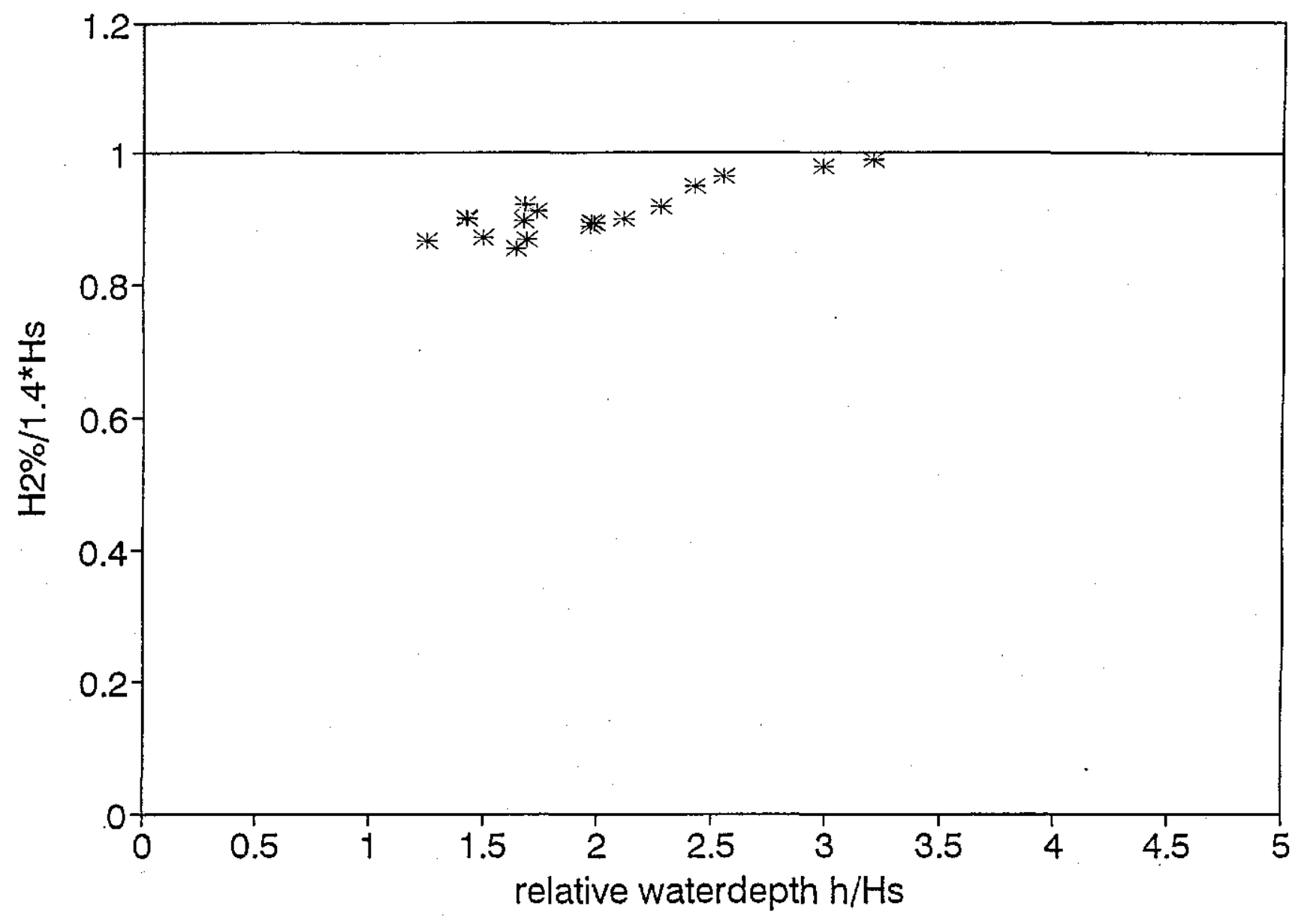

Figure 11 
damage level $\mathrm{N}_{o d}$ as a function of significant wave height $\mathrm{H}_{3}$ for fixed stone diameters $D_{n 50}$

$S_{o p}=0.02 h=0.7 m h_{a}-h_{t}=0.08 m b_{t}=0.12 m$

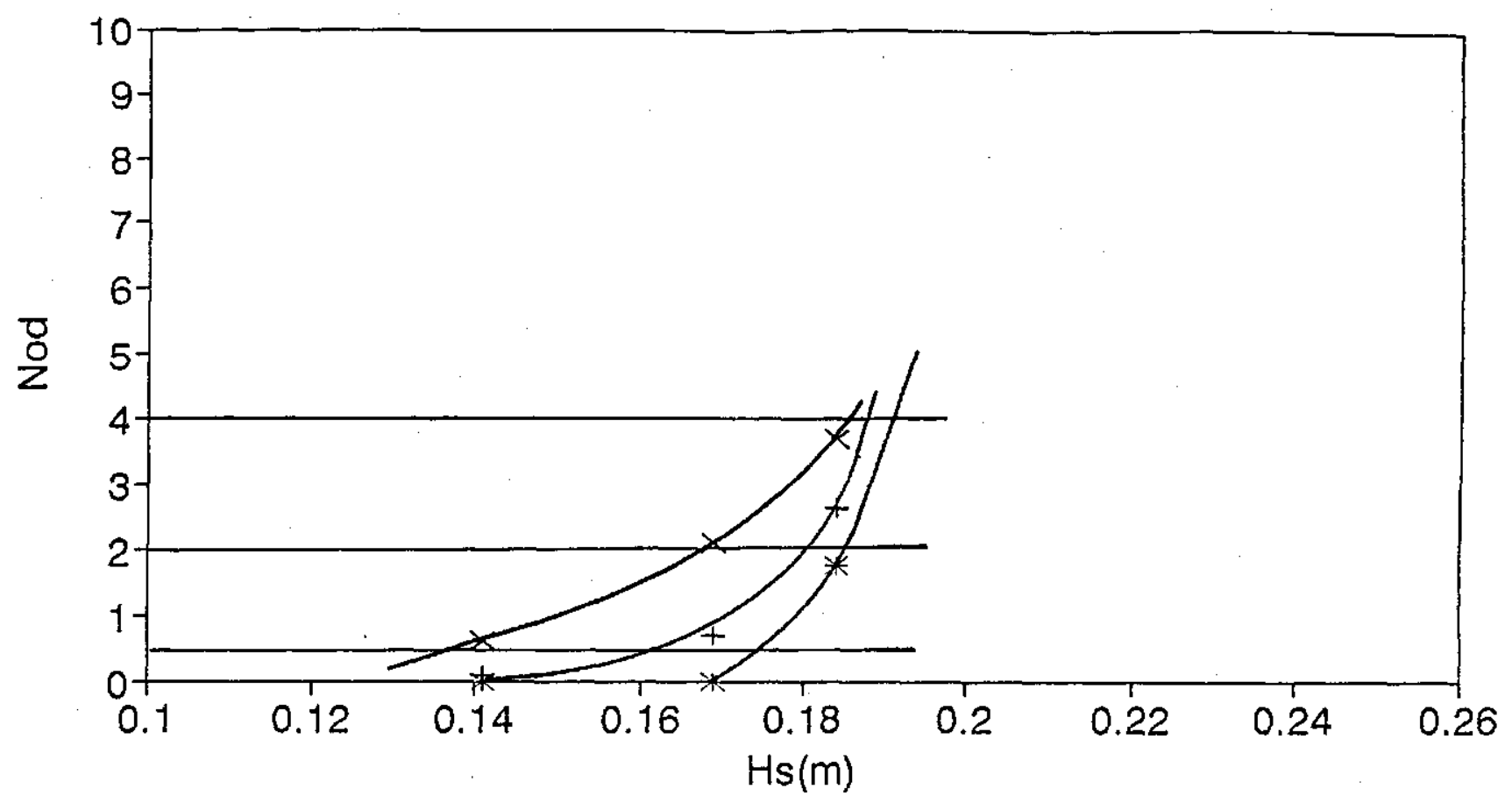

$$
\times D_{n 50}=0.017 \mathrm{~mm}+D_{n 50}=0.025 \mathrm{~m} \quad * D_{n 50}=0.035 \mathrm{~m}
$$

$s_{o p}=0.04 h=0.7 m h_{z}-h_{t}=0.08 m b_{t}=0.12 m$

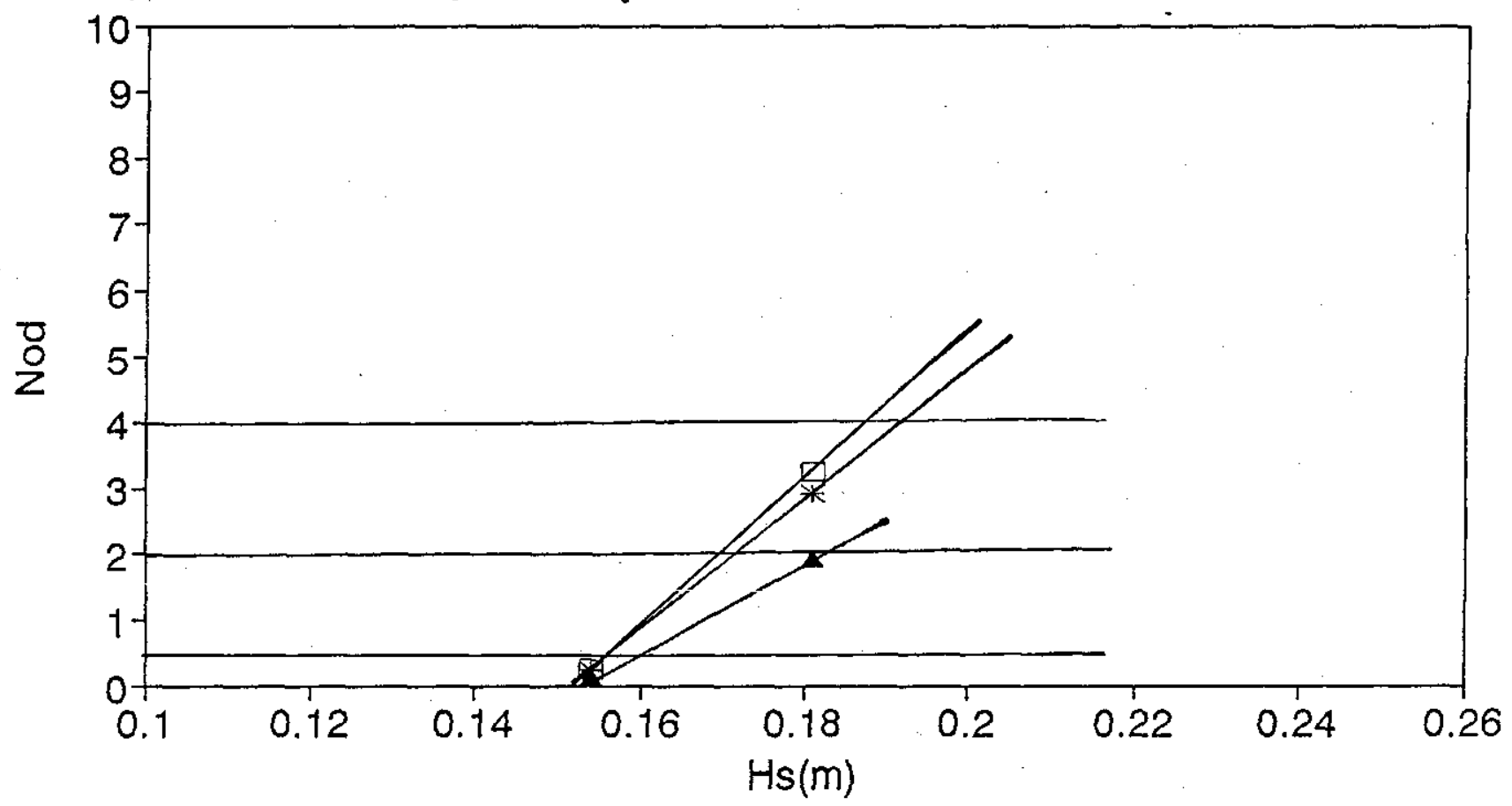

* $\quad D_{n 50}=0.017 \mathrm{~m} \square \quad D_{n 50}=0.025 \mathrm{~m} \quad \triangle \quad D_{n 50}=0.035 \mathrm{~m}$ 
damage level $\mathrm{N}_{\mathrm{od}}$ as a function of significant wave height $\mathrm{H}_{3}$ for fixed stone diameters $D_{n 50}$

$S_{o p}=0.02 h=0.8 m h_{a}-h_{t}=0.08 m b_{t}=0.12 m$

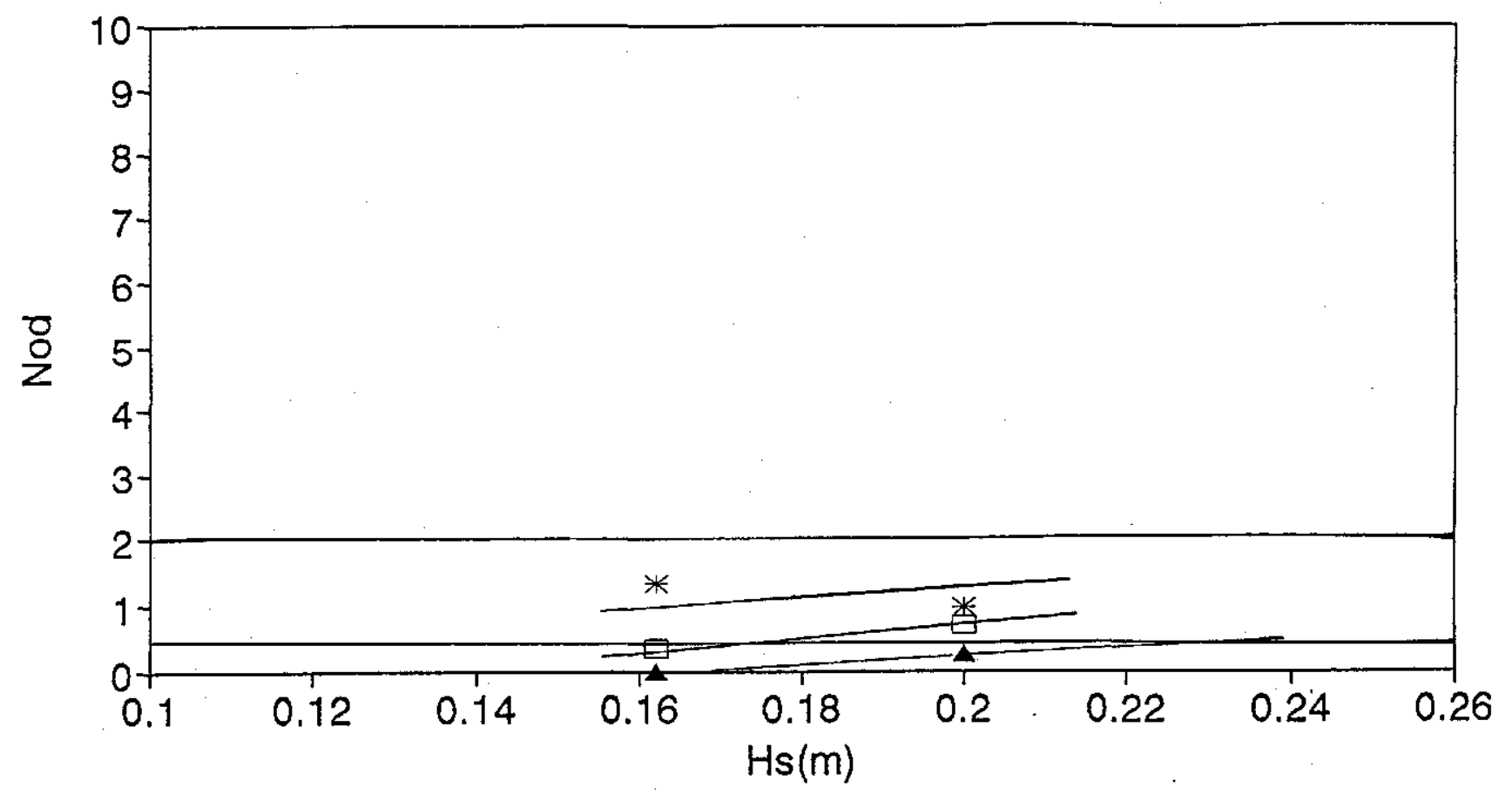

* $\quad D_{\mathrm{n} 50}=0.017 \mathrm{~m} \quad \square \quad D_{\mathrm{n} 50}=0.025 \mathrm{~m} \quad \mathrm{D}_{500}=0.035 \mathrm{~m}$

$\mathrm{s}_{\mathrm{op}}=0.04 \mathrm{~h}=0.8 \mathrm{~m} \mathrm{~h}_{\mathrm{s}}-\mathrm{h}_{\mathrm{t}}=0.08 \mathrm{~m} \mathrm{~b}_{\mathrm{t}}=0.12 \mathrm{~m}$

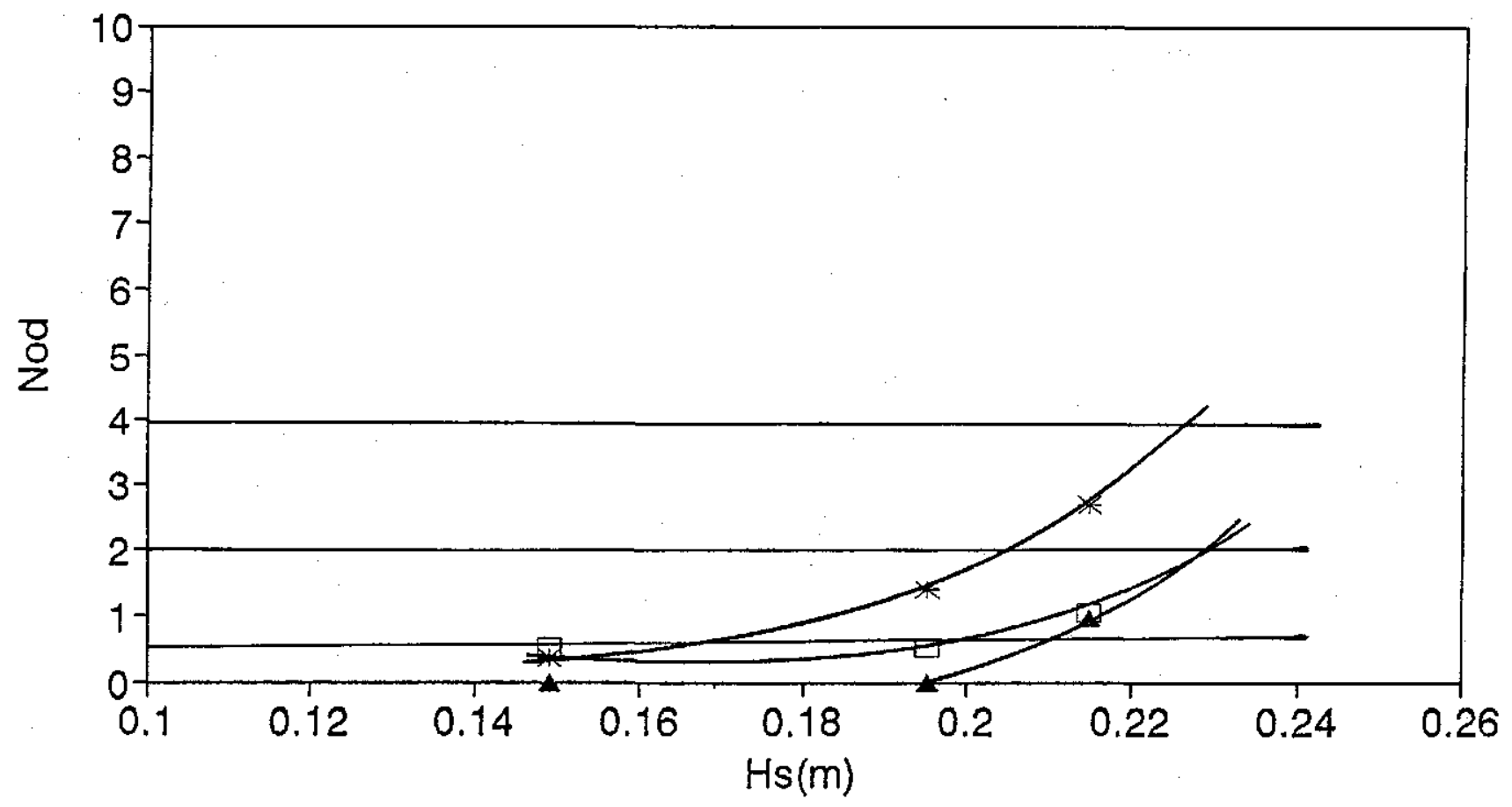

* $D_{\mathrm{n} 50}=0.017 \mathrm{~m} \quad \square \quad D_{\mathrm{n} 50}=0.025 \mathrm{~m} \wedge \mathrm{D}_{\mathrm{h} 50}=0.035 \mathrm{~m}$ 
damage level $\mathrm{N}_{\mathrm{od}}$ as a function of significant wave height $\mathrm{H}_{\mathrm{s}}$ for fixed stone diameters $D_{n 50}$

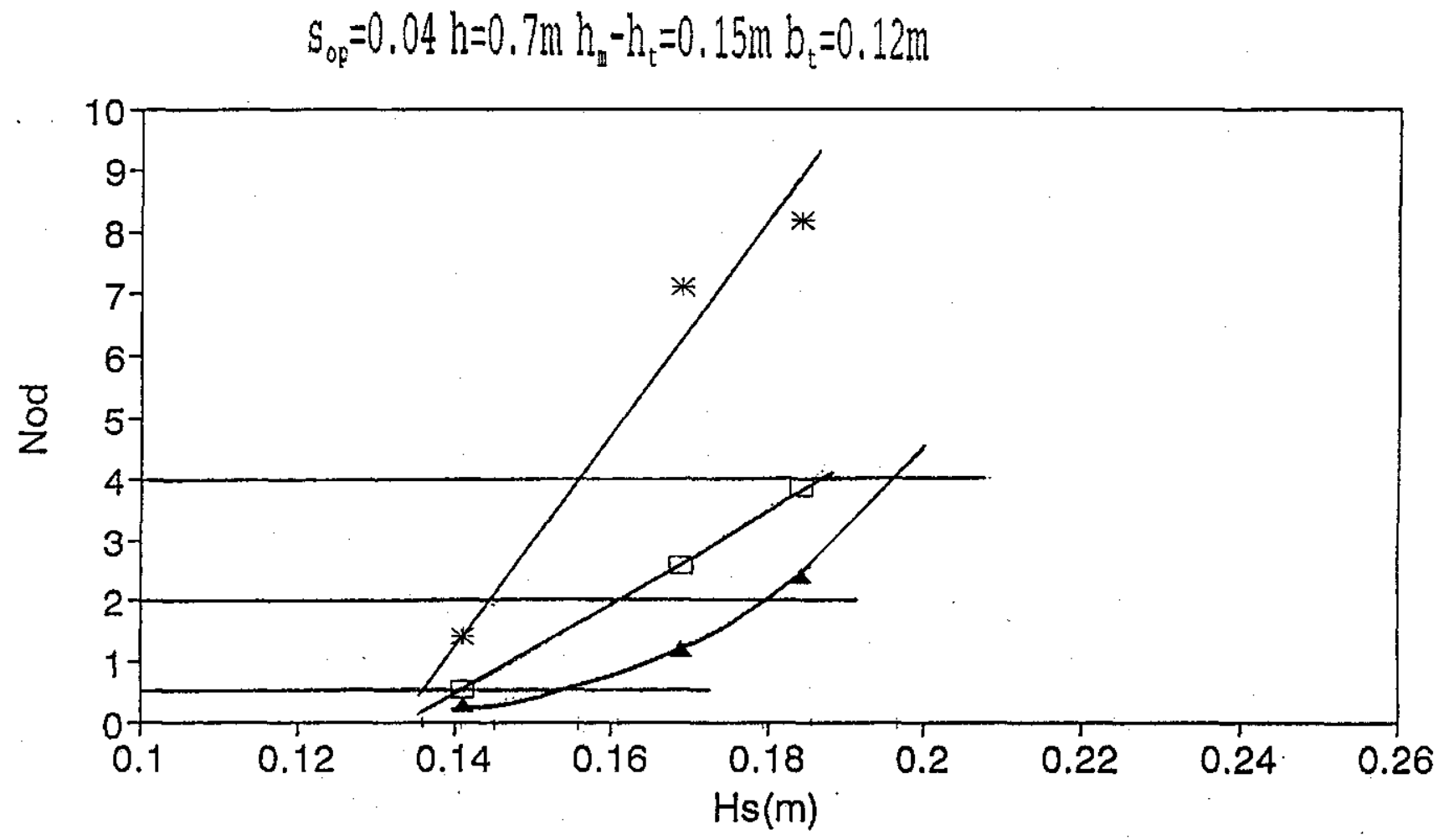

* $\quad D_{n 50}=0.025 \mathrm{~m} \quad \square \quad D_{a 50}=0.035 \mathrm{~m} \quad \triangle \quad D_{\mathrm{n} 50}=0.040 \mathrm{~m}$ 
damage level $\mathrm{N}_{o d}$ as a function of signiticant wave helgnt $\mathrm{H}_{\mathrm{s}}$ tor tixed stone diameters $D_{n 50}$

$s_{o p}=0.02 h=0.9 m h_{s}-h_{t}=0.08 m b_{t}=0.12 m$
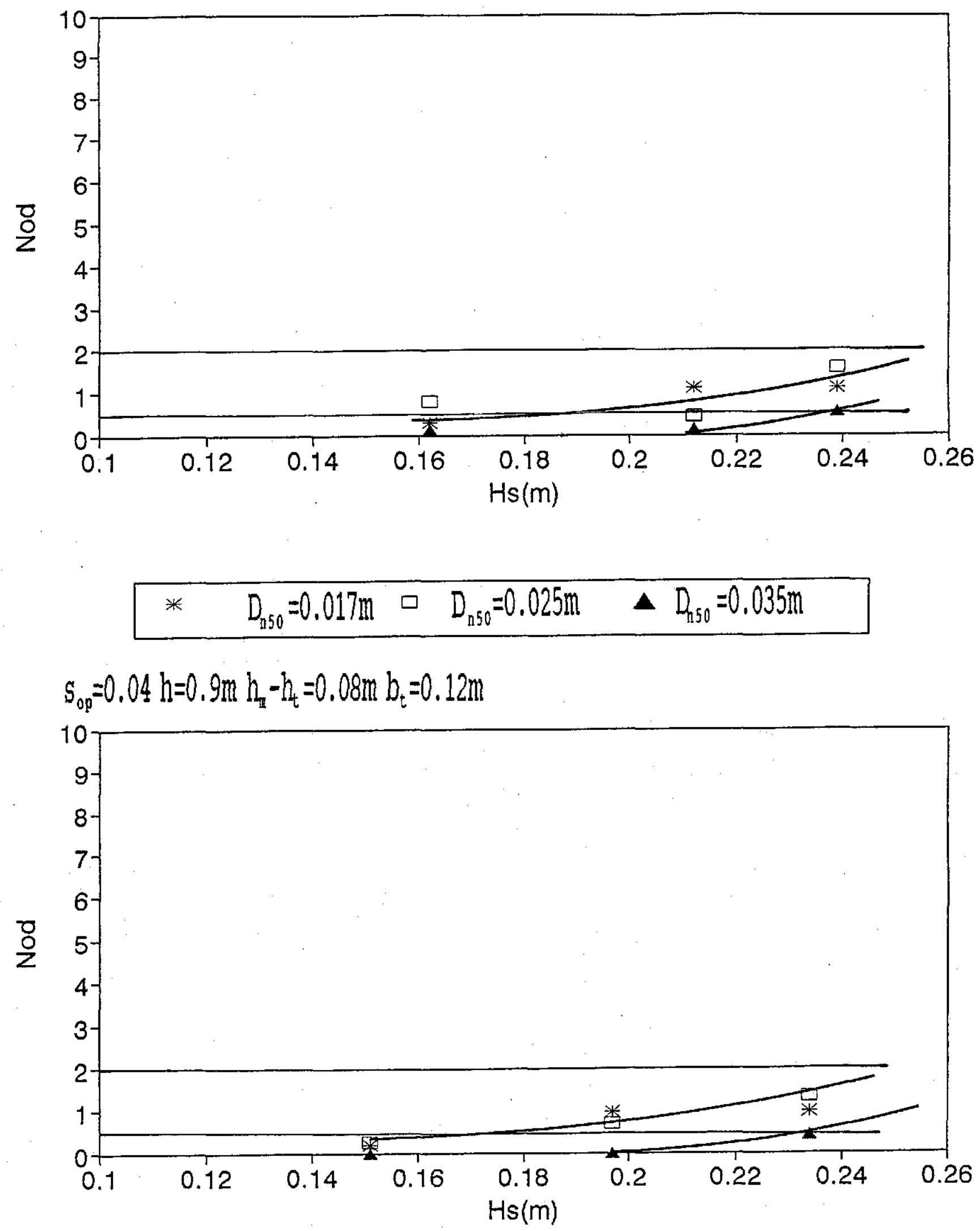

* $\quad D_{\mathrm{n} 50}=0.017 \mathrm{~m} \quad \square \quad D_{\mathrm{n} 50}=0.025 \mathrm{~m} \quad \Delta \quad D_{150}=0.035 \mathrm{~m}$ 
damage level $\mathrm{N}_{o d}$ as a function of significant wave height $\mathrm{H}_{\mathrm{s}}$ for fixed stone diameters $D_{n 50}$

$S_{o p}=0.02 h=0.7 m h_{a}-h_{t}=0.15 m b_{t}=0.12 m$

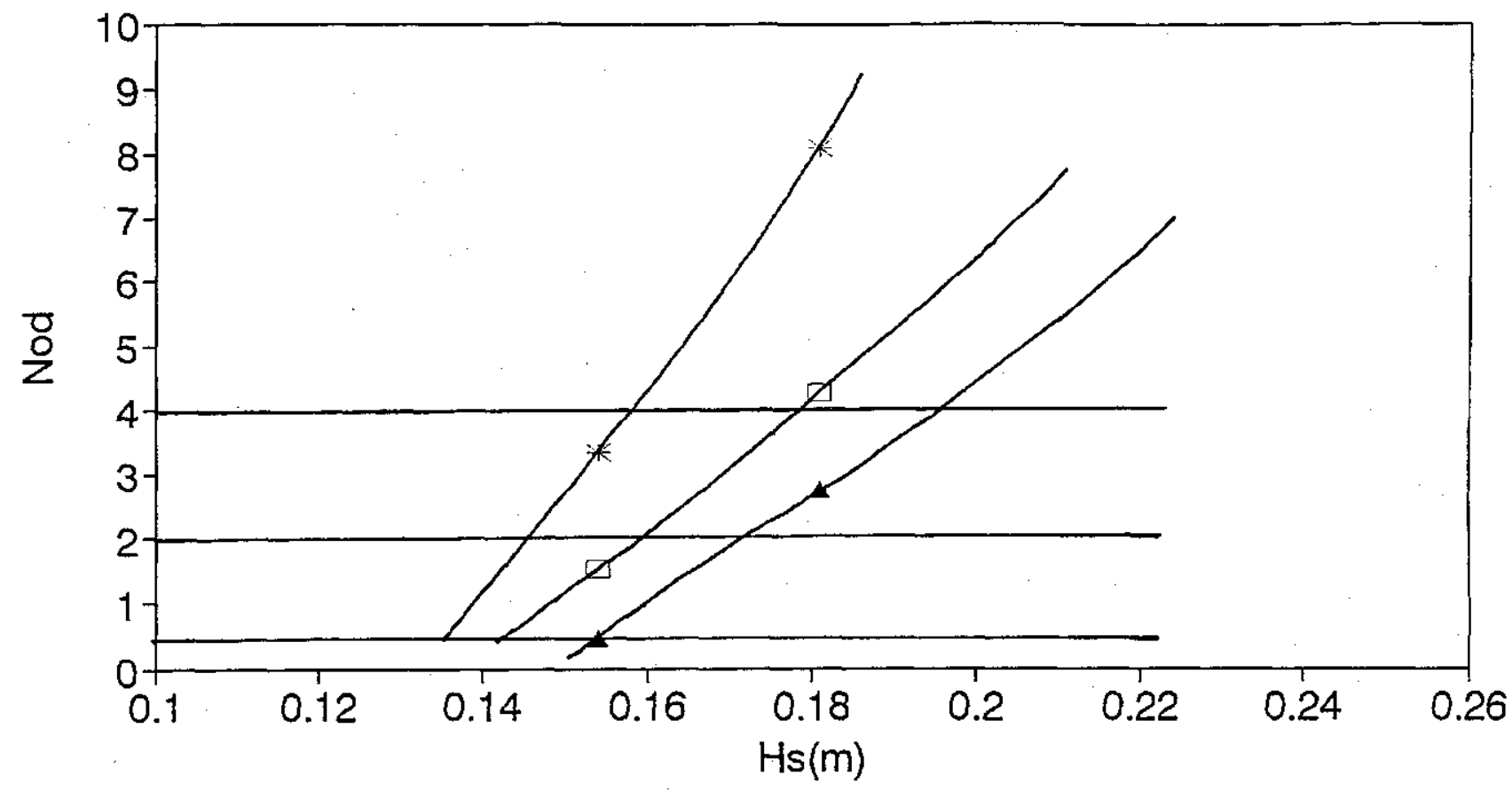

* $D_{550}=0.025 \mathrm{~m} \quad \square \quad D_{n 50}=0.035 \mathrm{~m} \quad \triangle D_{150}=0.040 \mathrm{~m}$

$S_{o p}=0.04 h=0.7 m h_{1}-h_{t}=0.15 m b_{t}=0.12 m$

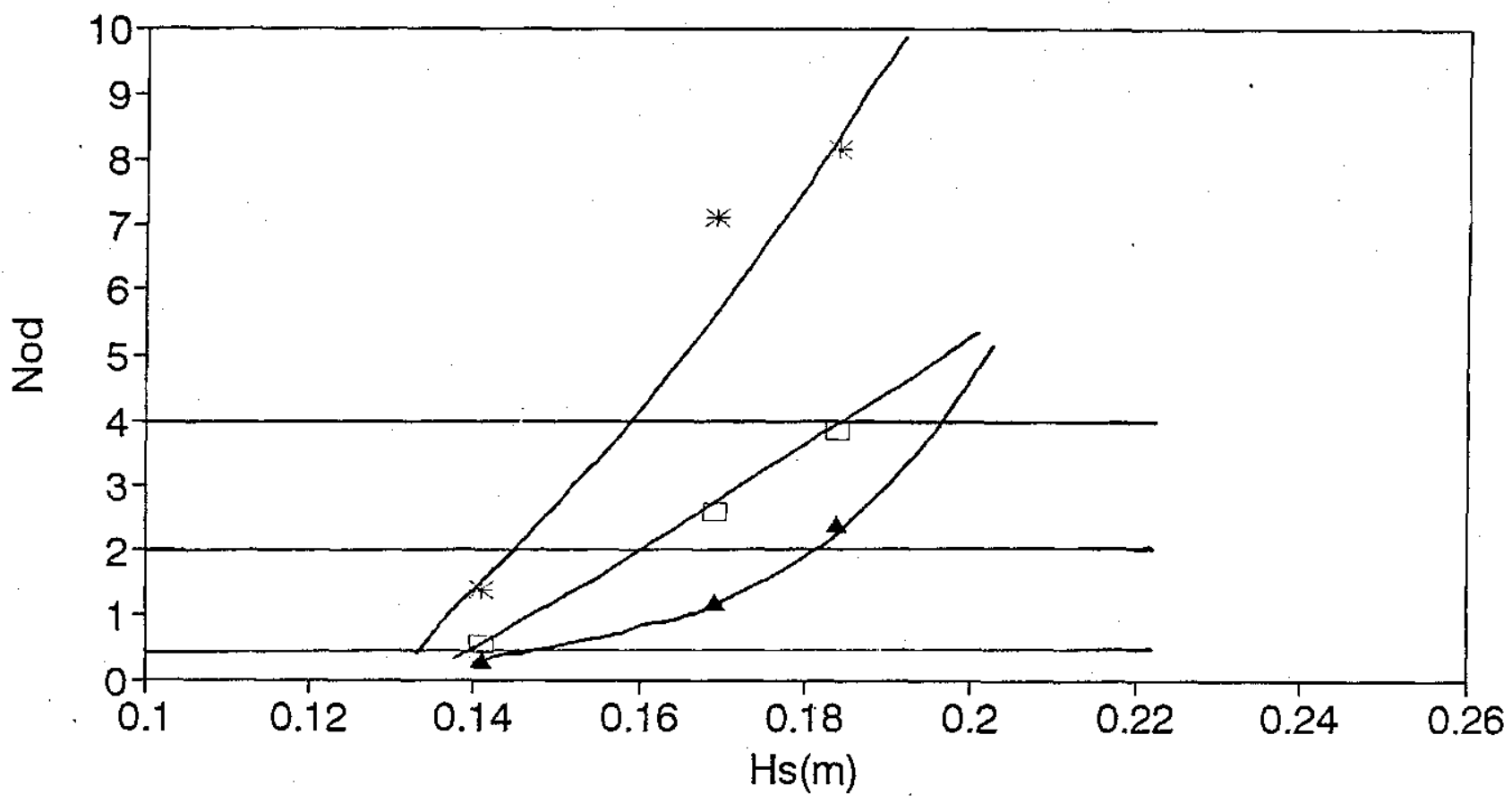

* $D_{n 50}=0.025 \mathrm{~m} \square D_{n 50}=0.035 \mathrm{~m} \quad D_{\mathrm{n} 50}=0.040 \mathrm{~m}$ 
damage level $N_{\text {od }}$ as a function of significant wave height $\mathrm{H}_{s}$ for fixed stone diameters $D_{n 50}$

$s_{o p}=0.02 h=0.8 m h_{a}-h_{t}=0.15 m b_{t}=0.12 \mathrm{~m}$

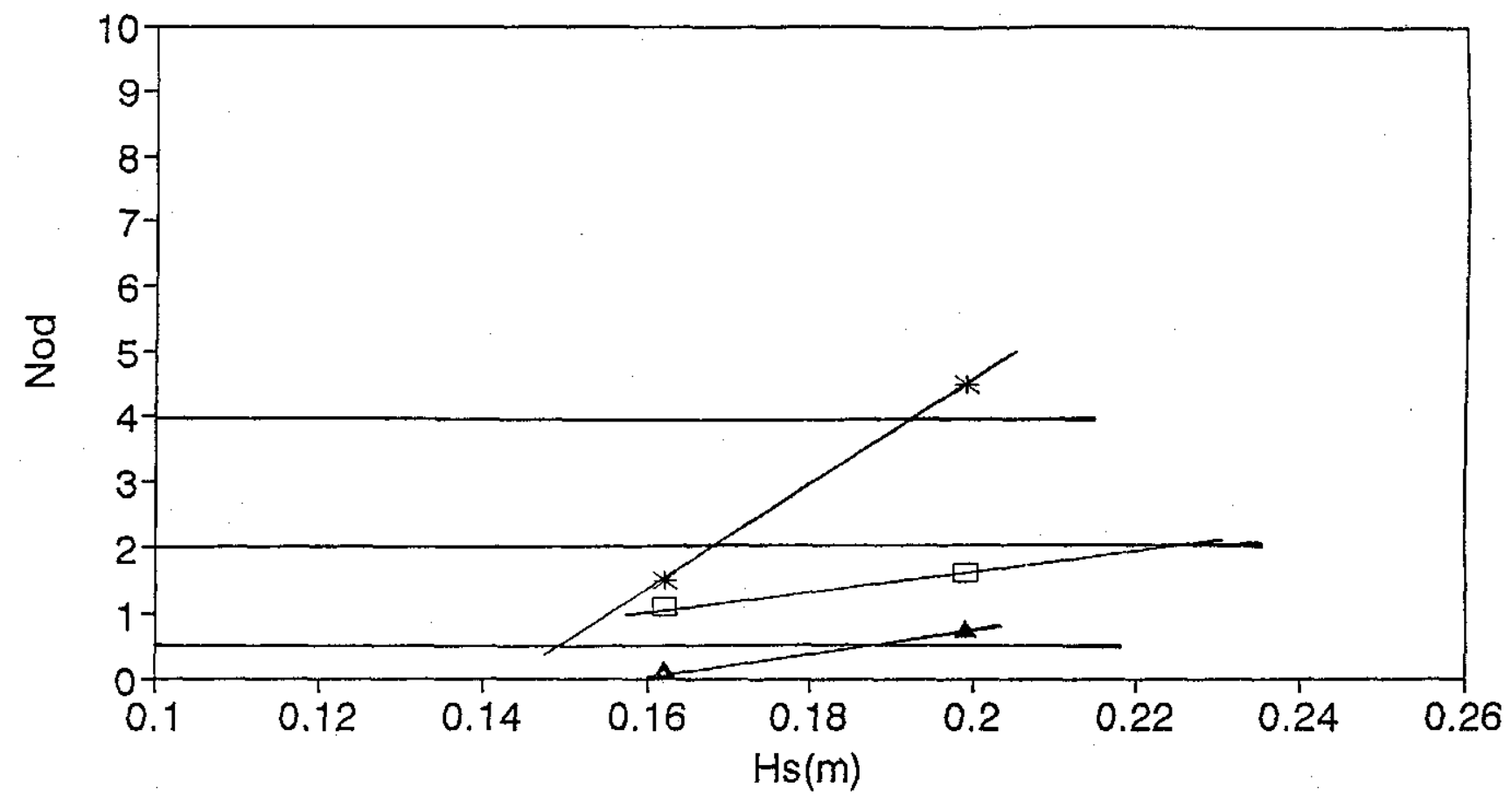

* $\quad D_{n 50}=0.025 \mathrm{~m} \quad \square \quad D_{n 50}=0.035 \mathrm{~m} \quad \triangle D_{n 50}=0.040 \mathrm{~m}$

$S_{o p}=0.04 h=0.8 m h_{c}-h_{t}=0.15 m b_{t}=0.12 m$

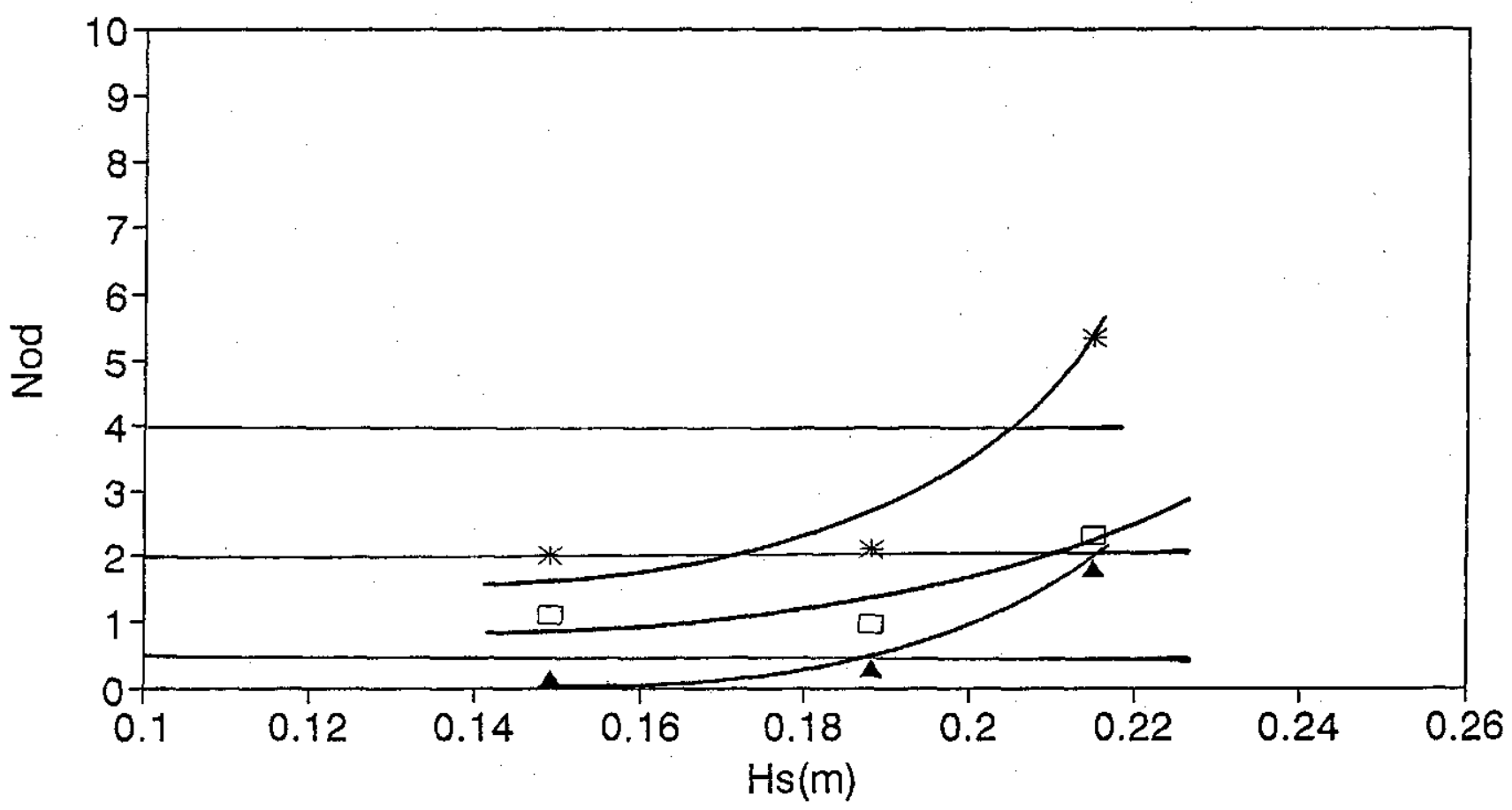

* $\quad D_{n 50}=0.025 \mathrm{~m} \quad \square \quad D_{n 50}=0.035 \mathrm{~m}: \Delta \quad D_{150}=0.040 \mathrm{~m}$ 
damage level $\mathrm{N}_{o d}$ as a function of significant wave height $\mathrm{H}_{\mathrm{s}}$ for fixed stone diameters $D_{n 50}$

$s_{o p}=0.02 h=0.9 m h_{1}-h_{t}=0.15 m b_{t}=0.12 m$

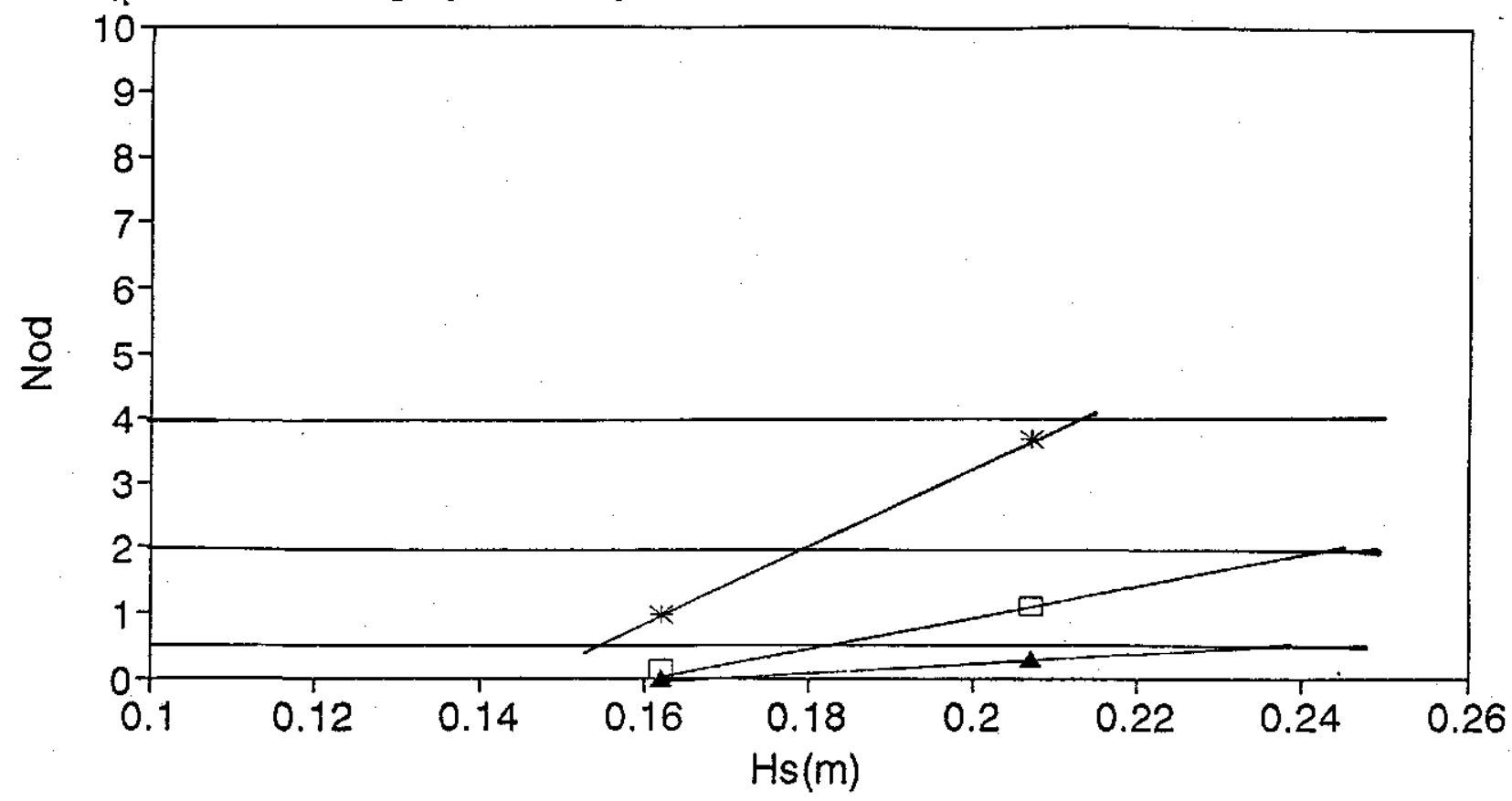

* $\quad D_{n 50}=0.025 \mathrm{~m} \quad \square \quad D_{n 50}=0.035 \mathrm{~m} \quad \Delta \quad D_{n 50}=0.040 \mathrm{~m}$

$S_{o p}=0.04 h=0.9 m h_{a}-h_{t}=0.15 m b_{t}=0.12 m$

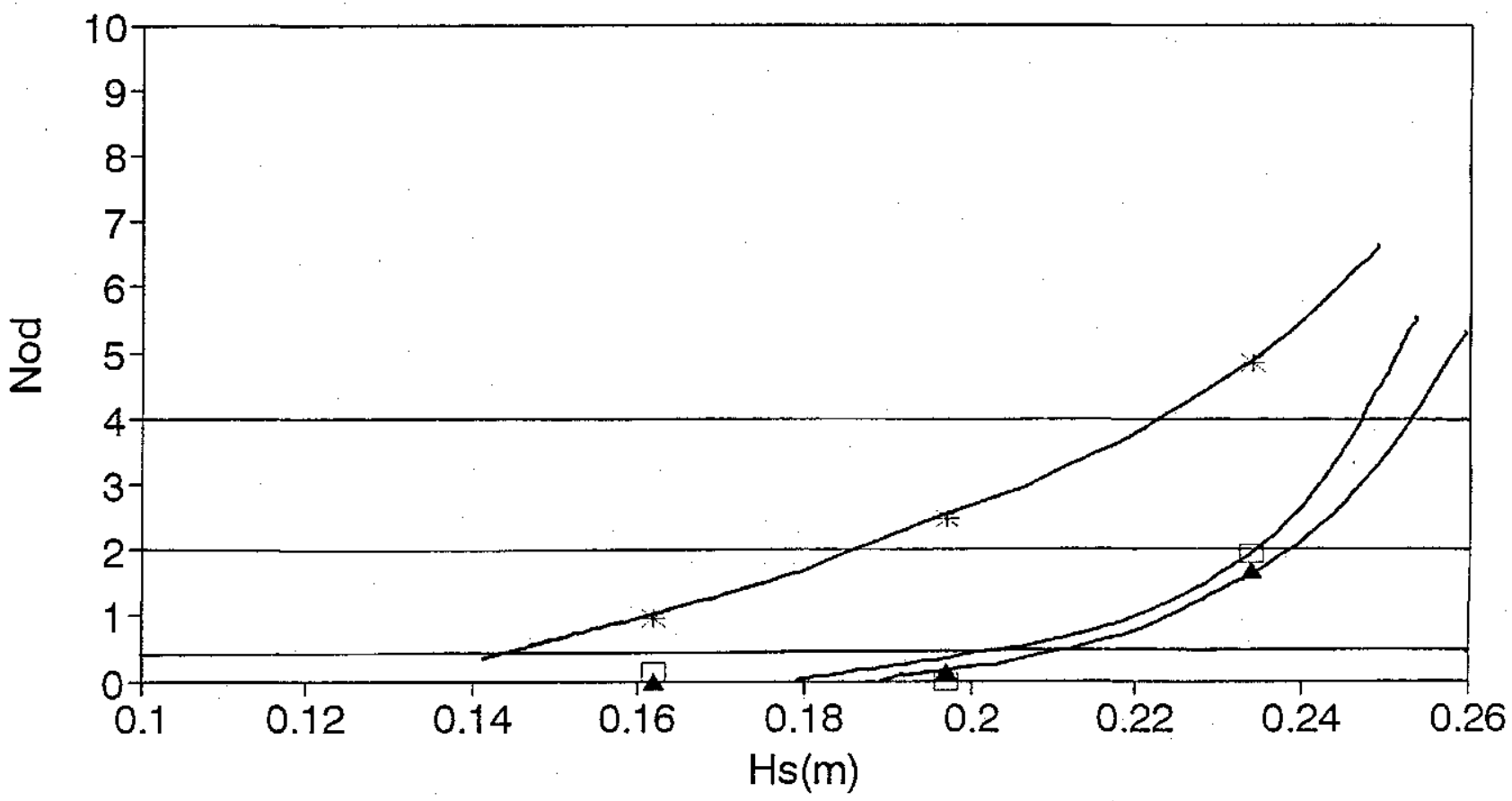

* $\quad D_{n 50}=0.025 \mathrm{~m} \quad \square \quad D_{n 50}=0.035 \mathrm{~m} \quad \therefore \quad D_{n 50}=0.040 \mathrm{~m}$ 
damage level $\mathrm{N}_{o d}$ as a function of significant wave height $\mathrm{H}_{\mathrm{s}}$ for fixed stone diameters $D_{n 50}$

$s_{o p}=0.02 h=0.8 m h_{a}-h_{t}=0.22 m b_{t}=0.12 m$

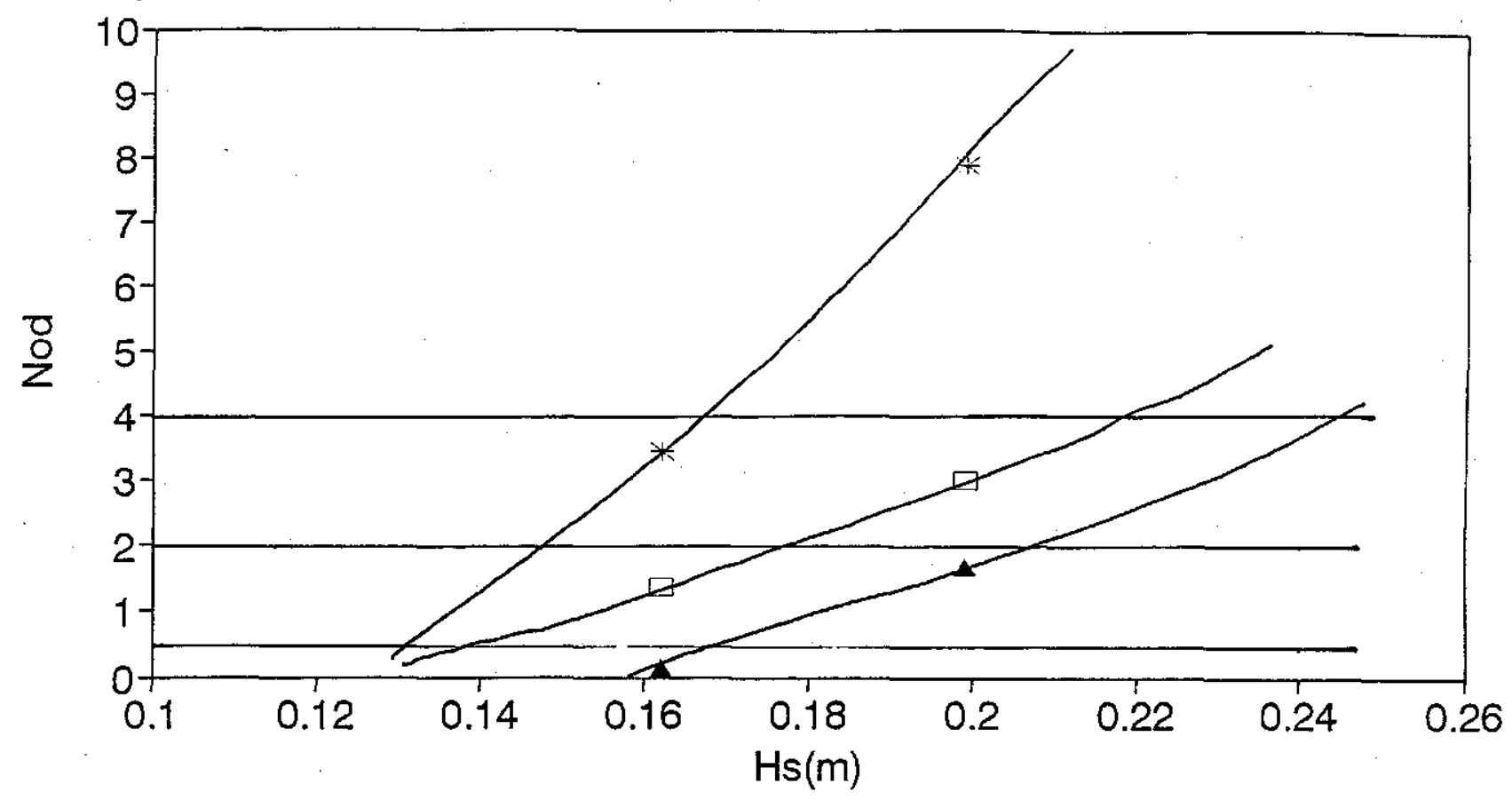

* $D_{n 50}=0.025 \mathrm{~m} \square D_{n 50}=0.035 \mathrm{~m} \wedge D_{n 50}=0.040 \mathrm{~m}$

$s_{o p}=0.04 h=0.8 m h_{t}-h_{t}=0.22 m b_{t}=0.12 m$

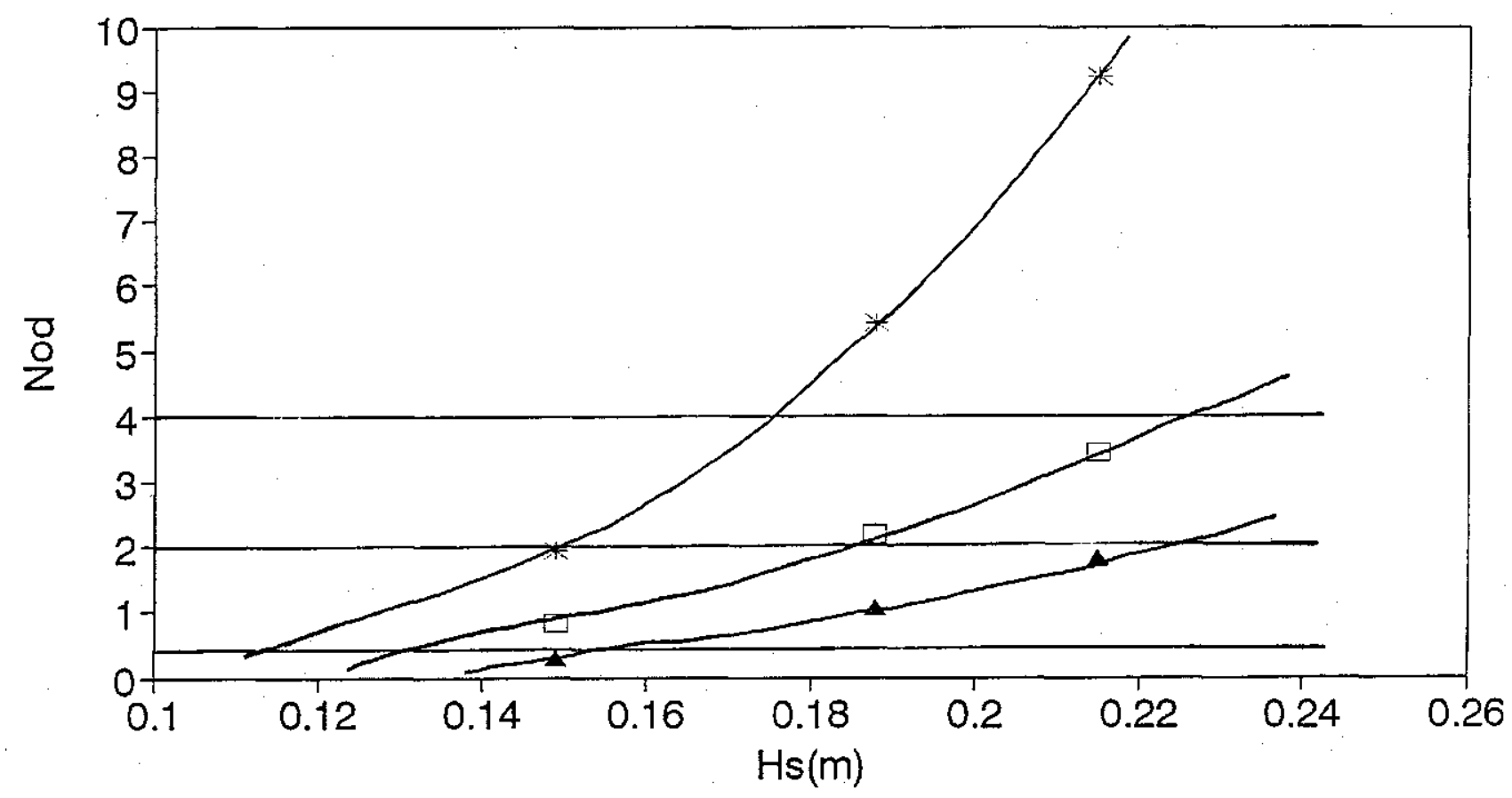

* $\quad D_{n 50}=0.025 \mathrm{~m} \quad \square \quad D_{n 50}=0.035 \mathrm{~m} \quad \Delta \quad D_{n 50}=0.040 \mathrm{~m}$ 
damage level $\mathrm{N}_{o d}$ as a function of significant wave height $\mathrm{H}_{\mathrm{s}}$ for fixed stone diameters $D_{\text {n50 }}$

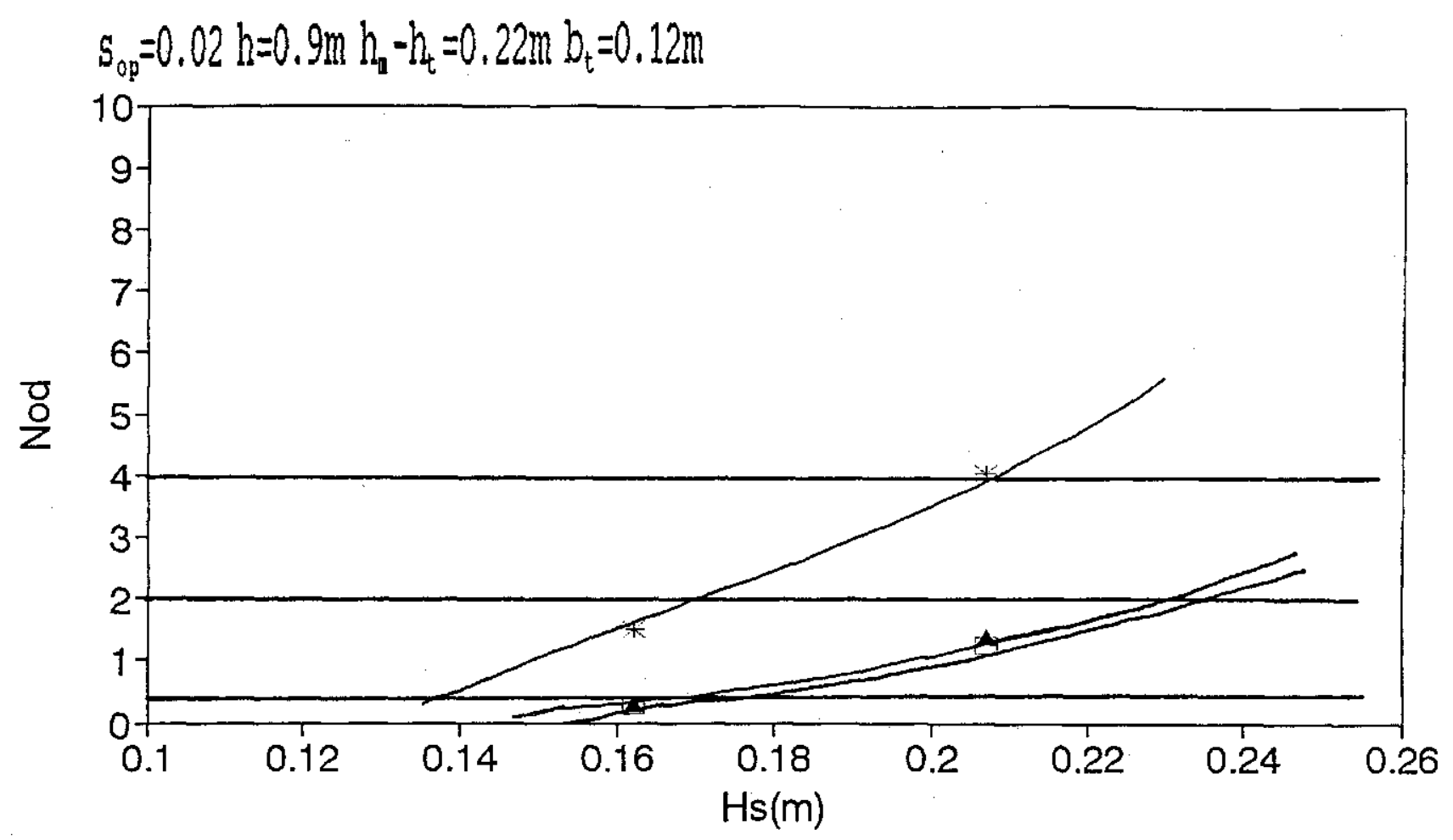

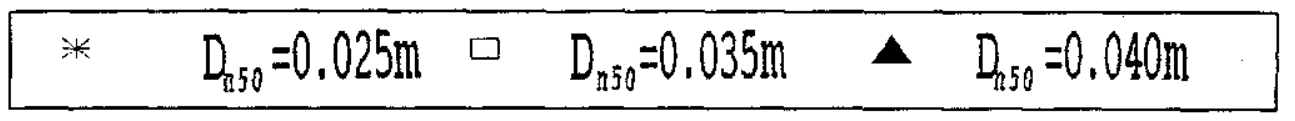

\section{$s_{o p}=0.04 h=0.9 m h_{n}-h_{t}=0.22 m b_{t}=0.12 m$}

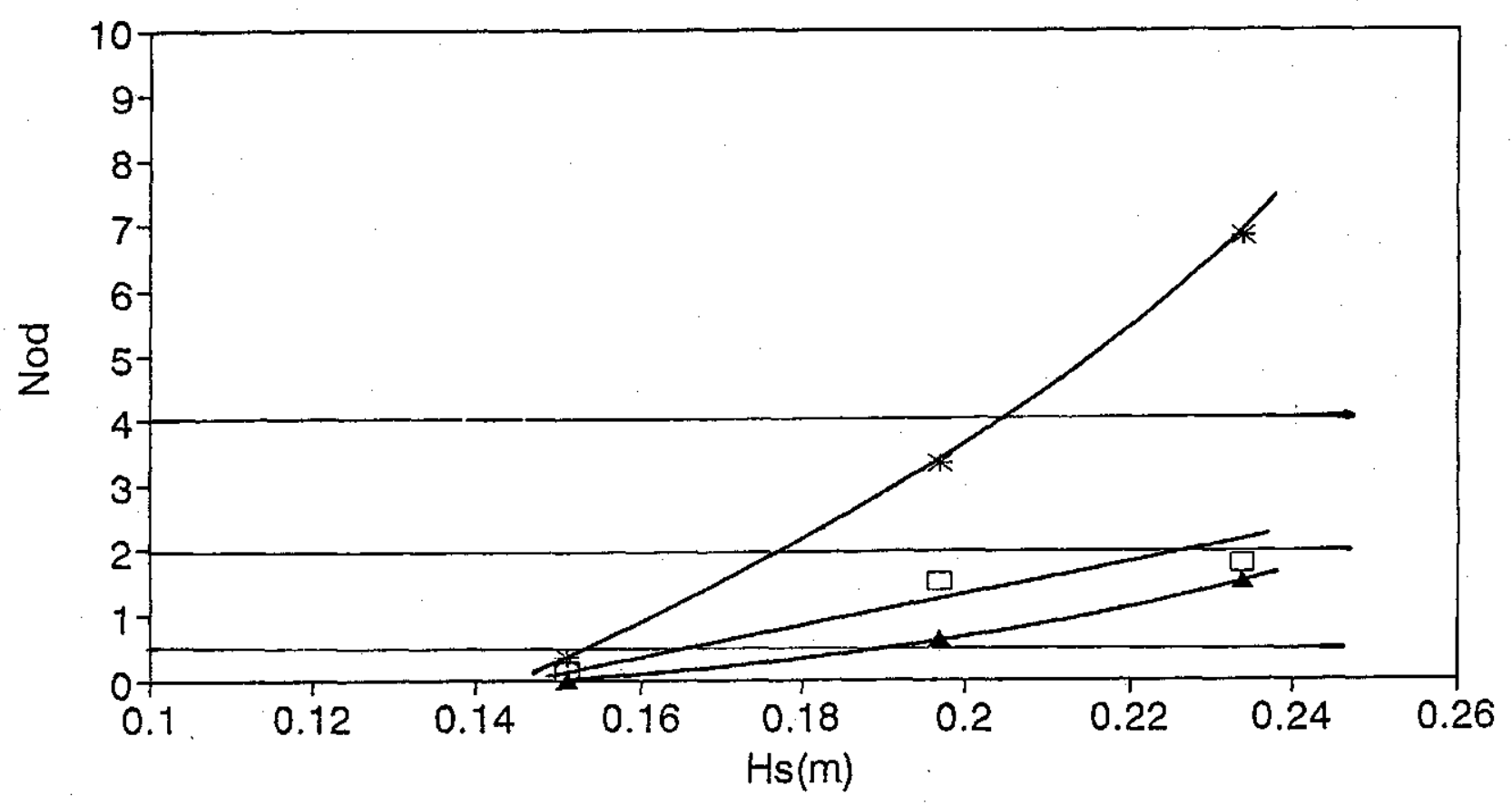

* $D_{n 50}=0.025 \mathrm{~m} \quad \square \quad D_{\mathrm{n} 50}=0.035 \mathrm{~m} \wedge \mathrm{D}_{550}=0.040 \mathrm{~m}$ 
damage level $\mathrm{N}_{o d}$ as a function of significant wave height $\mathrm{H}_{\mathrm{s}}$ for fixed stone diameters $D_{n 50}$

$s_{o p}=0.02 h=0.9 m h_{\mathrm{z}}-h_{t}=0.15 m b_{t}=0.20 m$

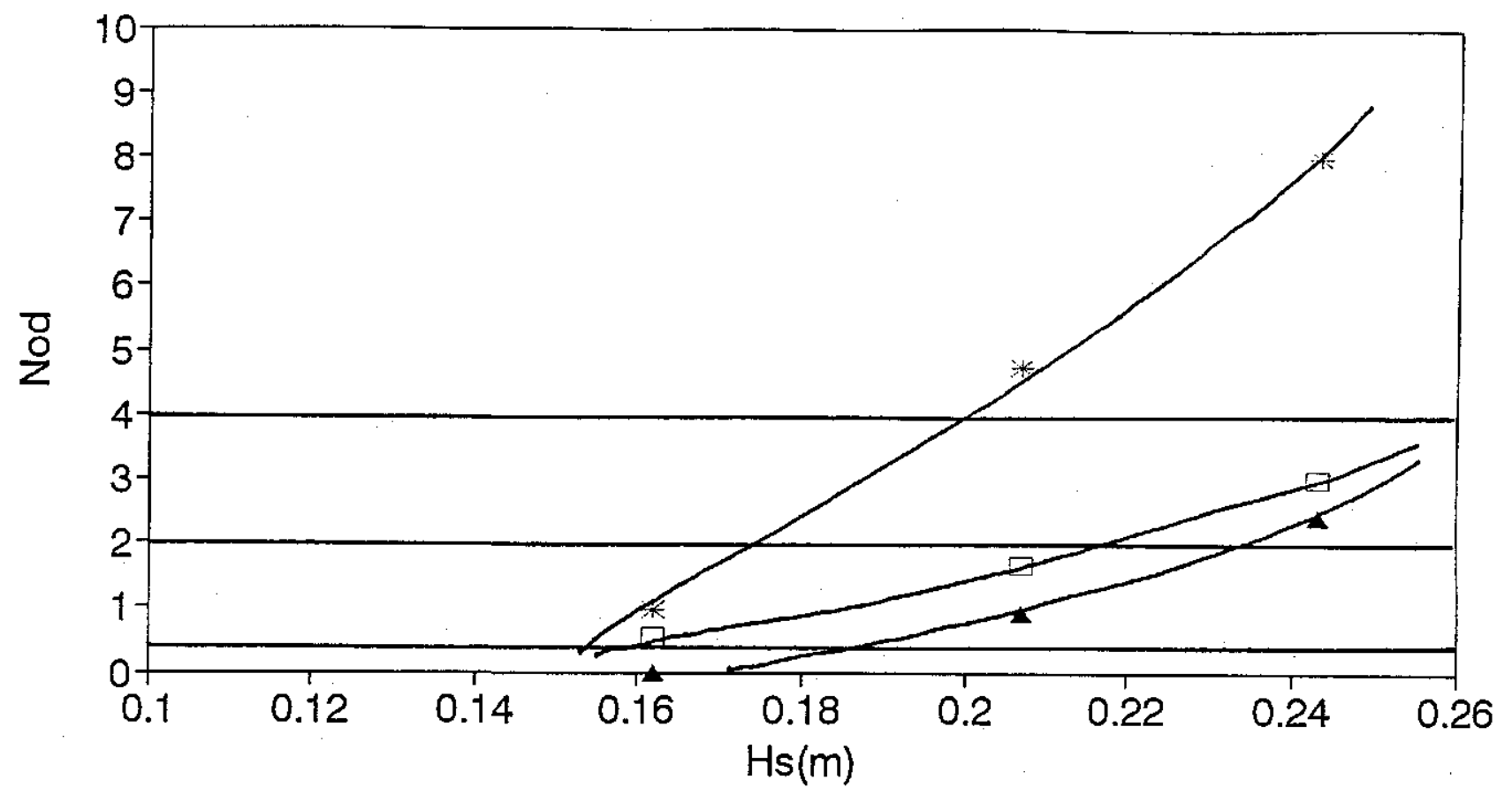

* $D_{n 50}=0.025 \mathrm{~m} \quad \square \quad D_{050}=0.035 \mathrm{~m} \wedge D_{n 50}=0.040 \mathrm{~m}$

$S_{o p}=0.04 h=0.9 m h_{1}-h_{t}=0.15 m b_{t}=0.20 m$

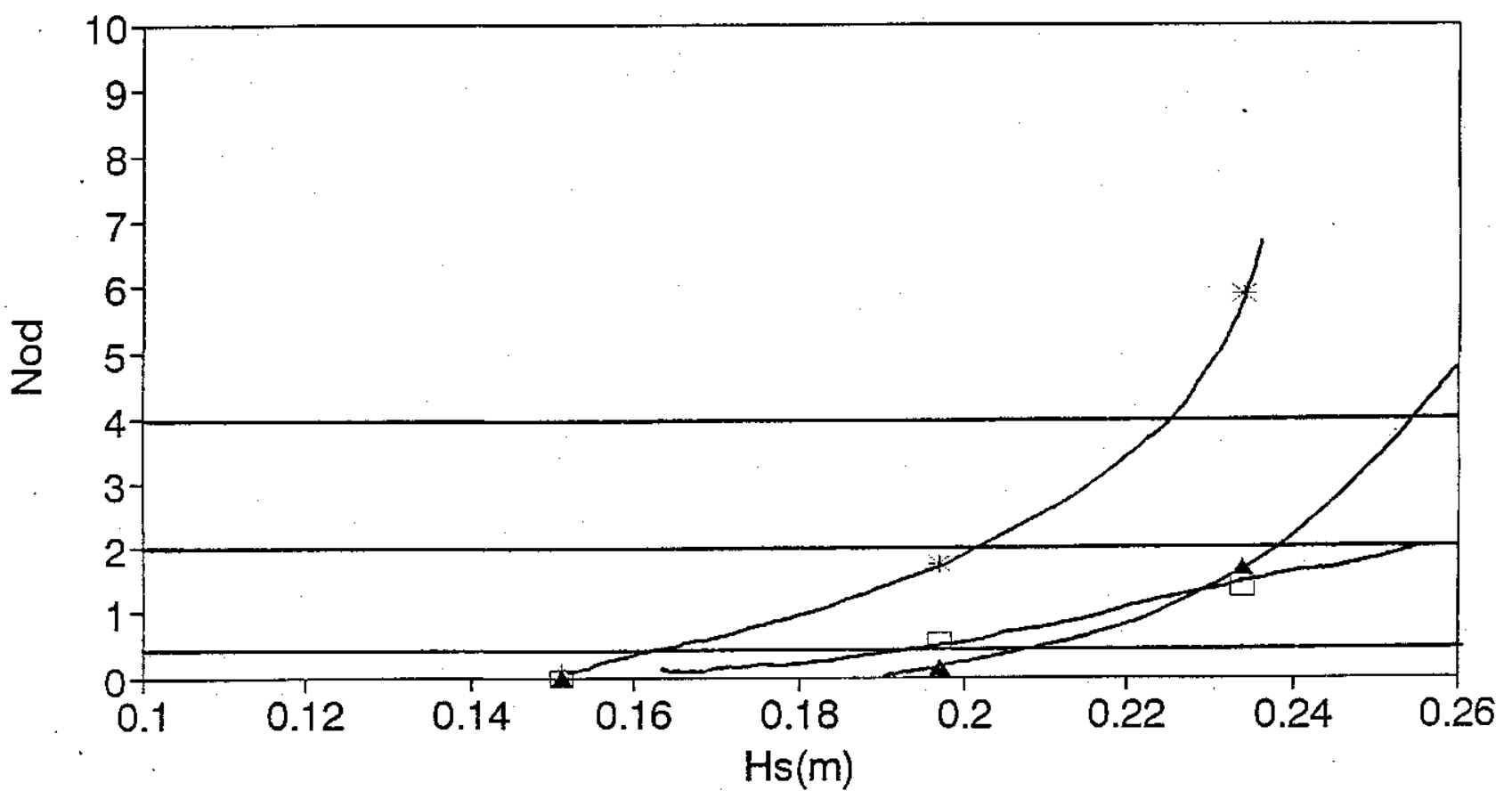

* $\quad D_{n 50}=0.025 \mathrm{~m} \quad \square \quad D_{n 50}=0.035 \mathrm{~m} \wedge D_{a 50}=0.040 \mathrm{~m}$ 
damage level $\mathbb{N}_{o d}$ as a function of significant wave height $H_{s}$ for fixed stone diameters $D_{n 50}$

$s_{o p}=0.02 h=0.9 m h_{a}-h_{t}=0.15 m b_{t}=0.30 \mathrm{~m}$

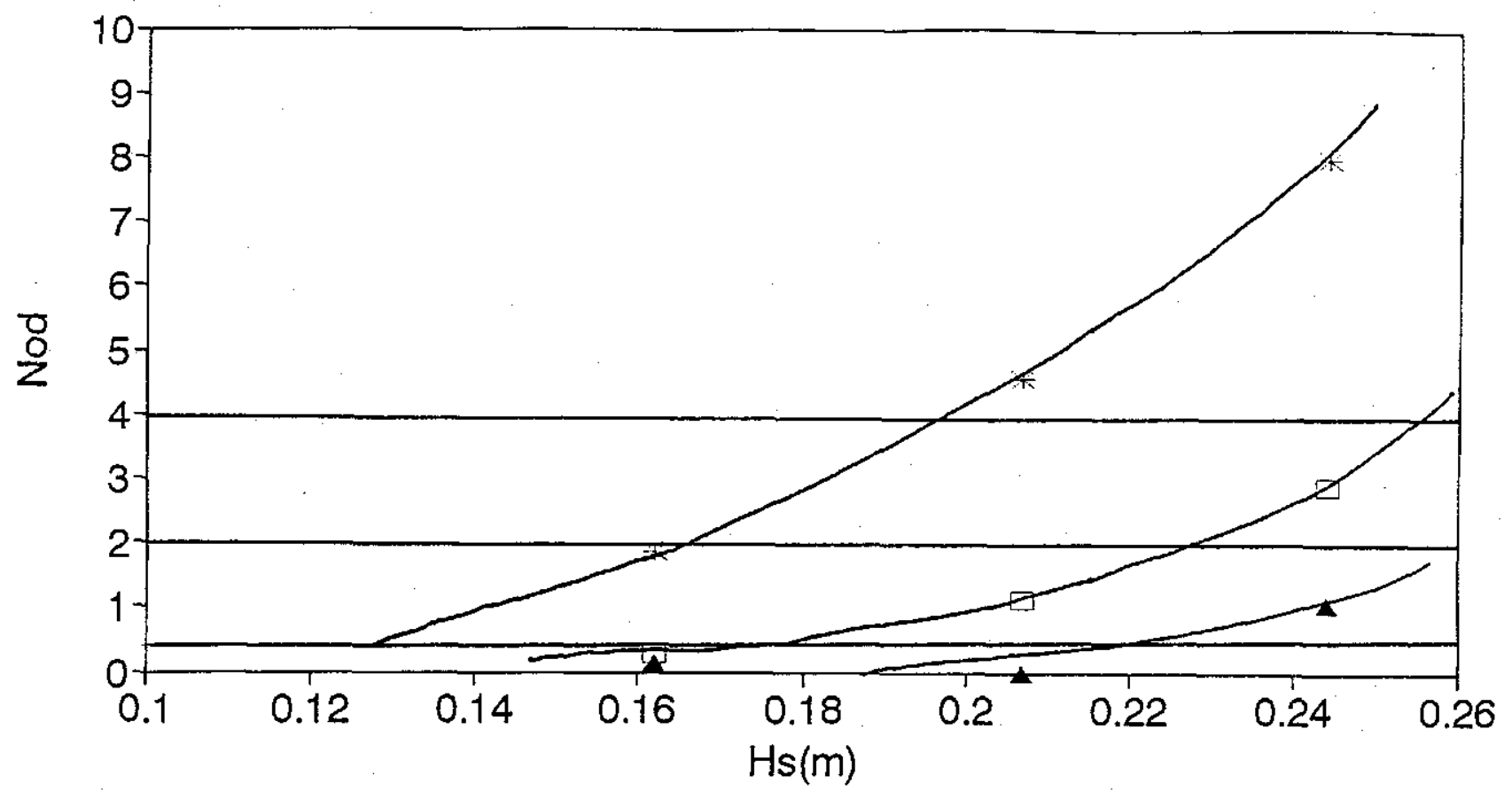

* $D_{\mathrm{n} 50}=0.025 \mathrm{~m} \quad \square \quad D_{n 50}=0.035 \mathrm{~m} \quad \sim D_{\mathrm{n} 50}=0.040 \mathrm{~m}$

$s_{o p}=0.04 h=0.9 m h_{a}-h_{t}=0.15 m b_{t}=0.30 m$

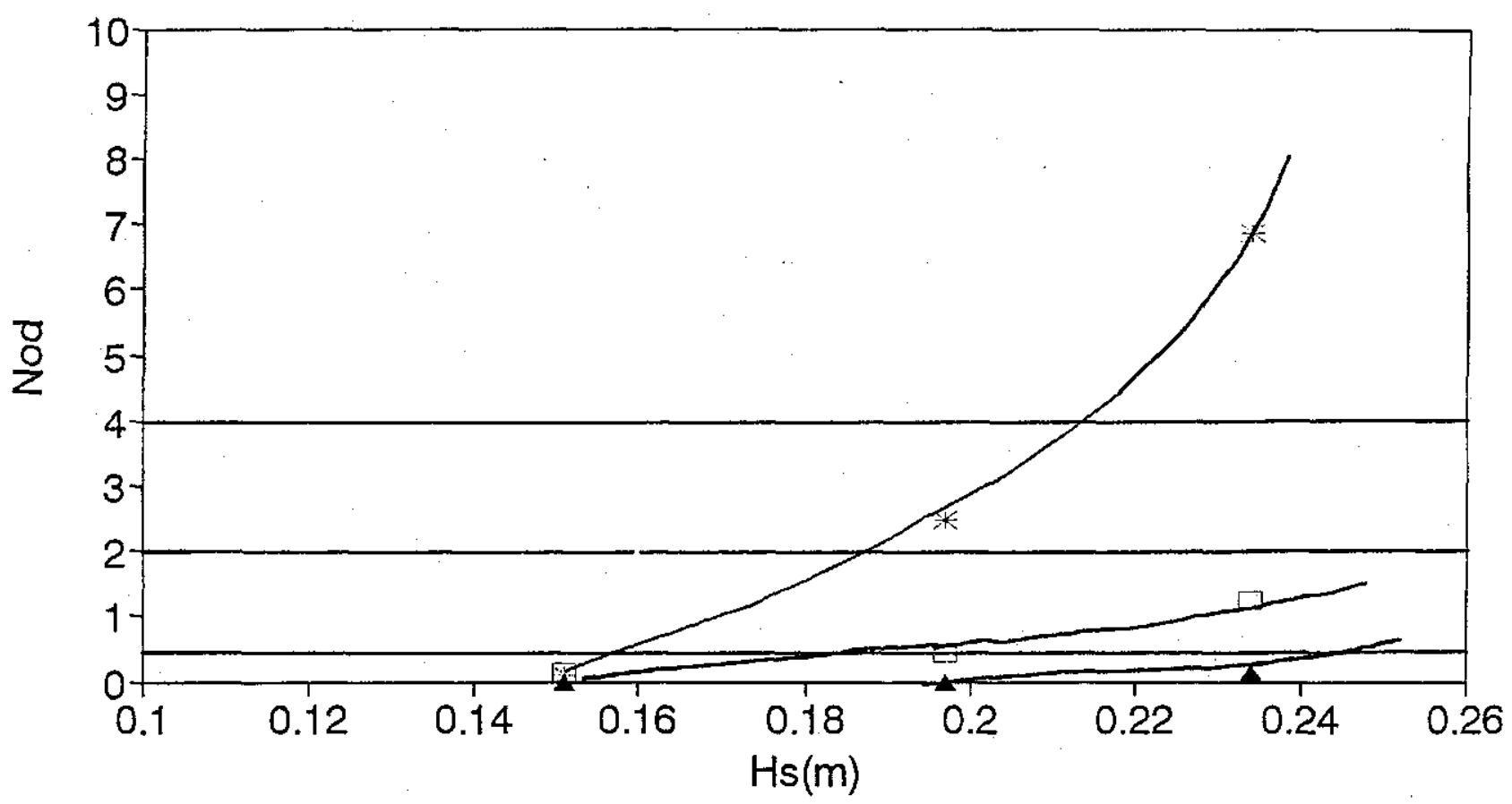

* $D_{\mathrm{n} 50}=0.025 \mathrm{~m} \quad \square \quad D_{\mathrm{n} 50}=0.035 \mathrm{~m} \wedge D_{\mathrm{n} 50}=0.040 \mathrm{~m}$ 
significant wave height $H_{s}$ as a function of fictitious wave steepness $s_{o p}$ for fixed damage levels $\mathrm{N}_{\mathrm{d}}$

$h=0.7 \mathrm{~m} h_{1}-h_{t}=0.08 m h_{q}=0.12 m h_{50}=0.017 \mathrm{~m}$

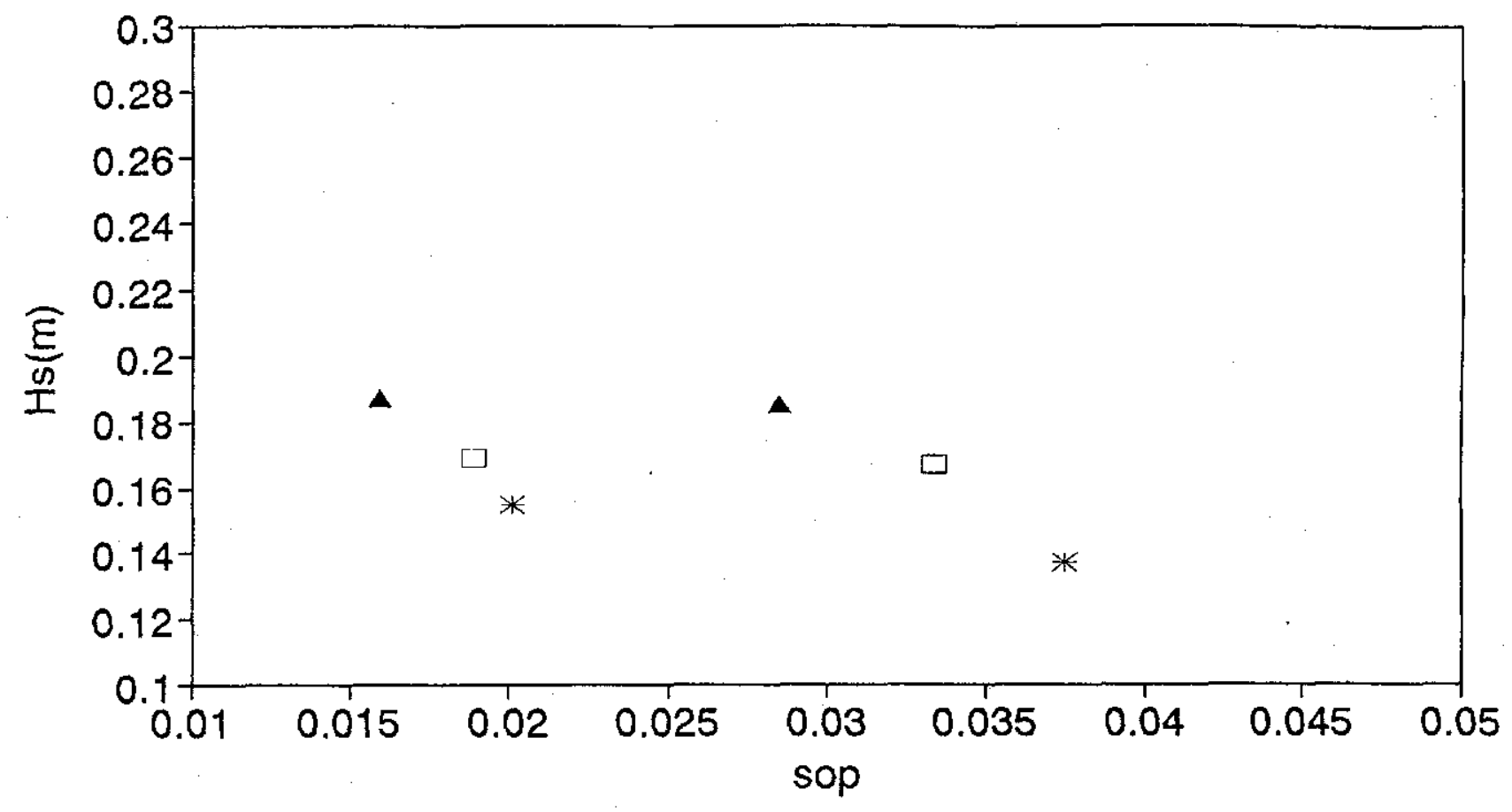

$*$ Nod=0.5 $\square \quad$ Nod=2 $\Delta \quad \mathrm{Nod}=4$

$h=0.7 m h_{a}-h_{t}=0.08 m h_{q}=0.12 m D_{a 50}=0.035 m$

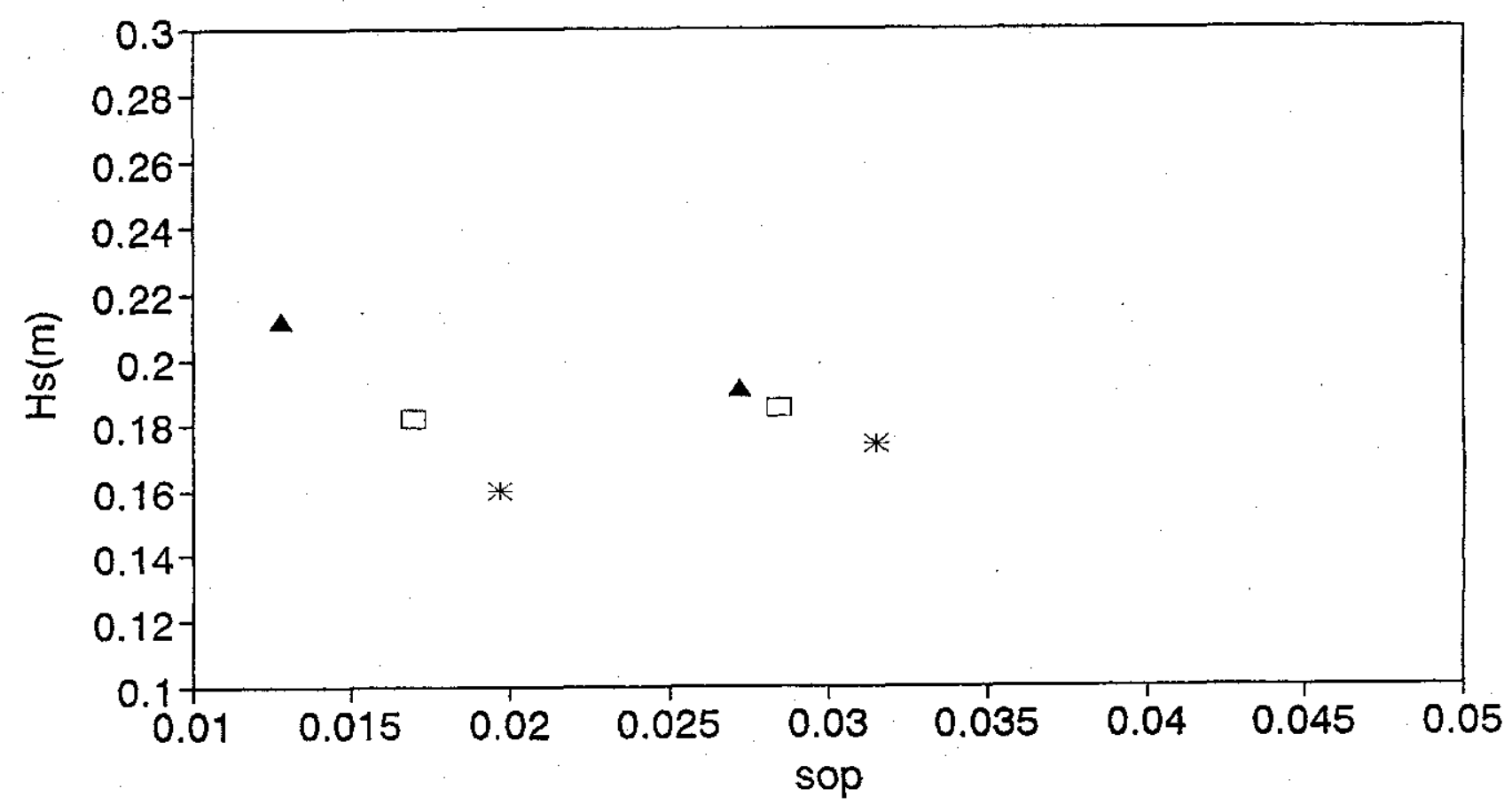

* $\mathrm{Nod}=0.5 \quad \square \quad \mathrm{Nod}=2 \quad \boldsymbol{N} \mathrm{Nod}=4$ 
significant wave height $H_{s}$ aS a function of fictitious wave steepness $S_{o p}$ for fixed damage levels $\mathbb{N}_{d}$.

$h=0.9 m h_{i}-h_{t}=0.15 m h_{t}=0.12 m h_{50}=0.025 m$

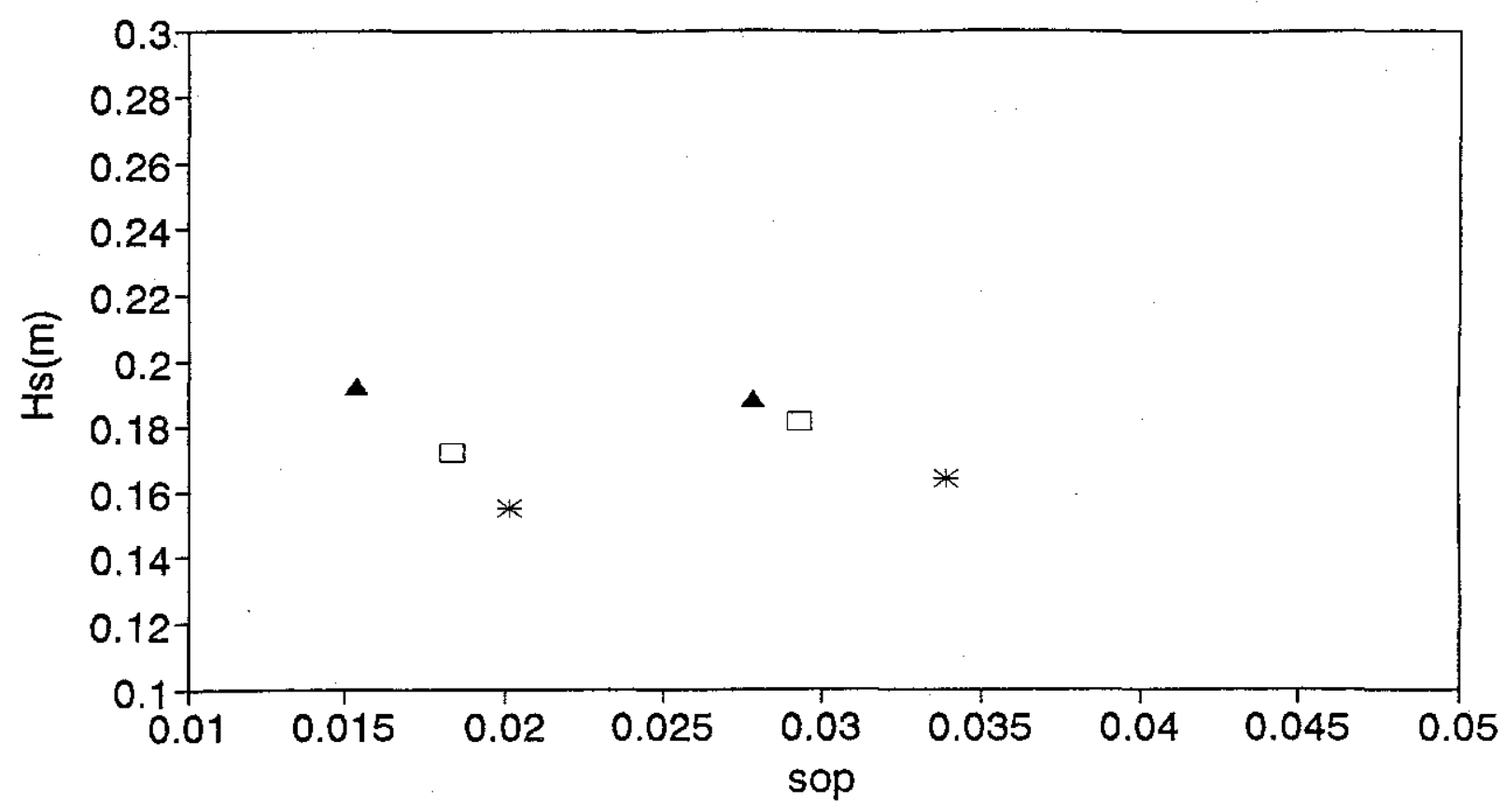

* Nod=0.5 $\square \quad \mathrm{Nod}=2 \quad \Delta \quad \mathrm{Nod}=4$

$h=0.8 m h_{m}-h_{q}=0.22 m h_{q}=0.12 m D_{n 50}=0.025 \mathrm{~m}$

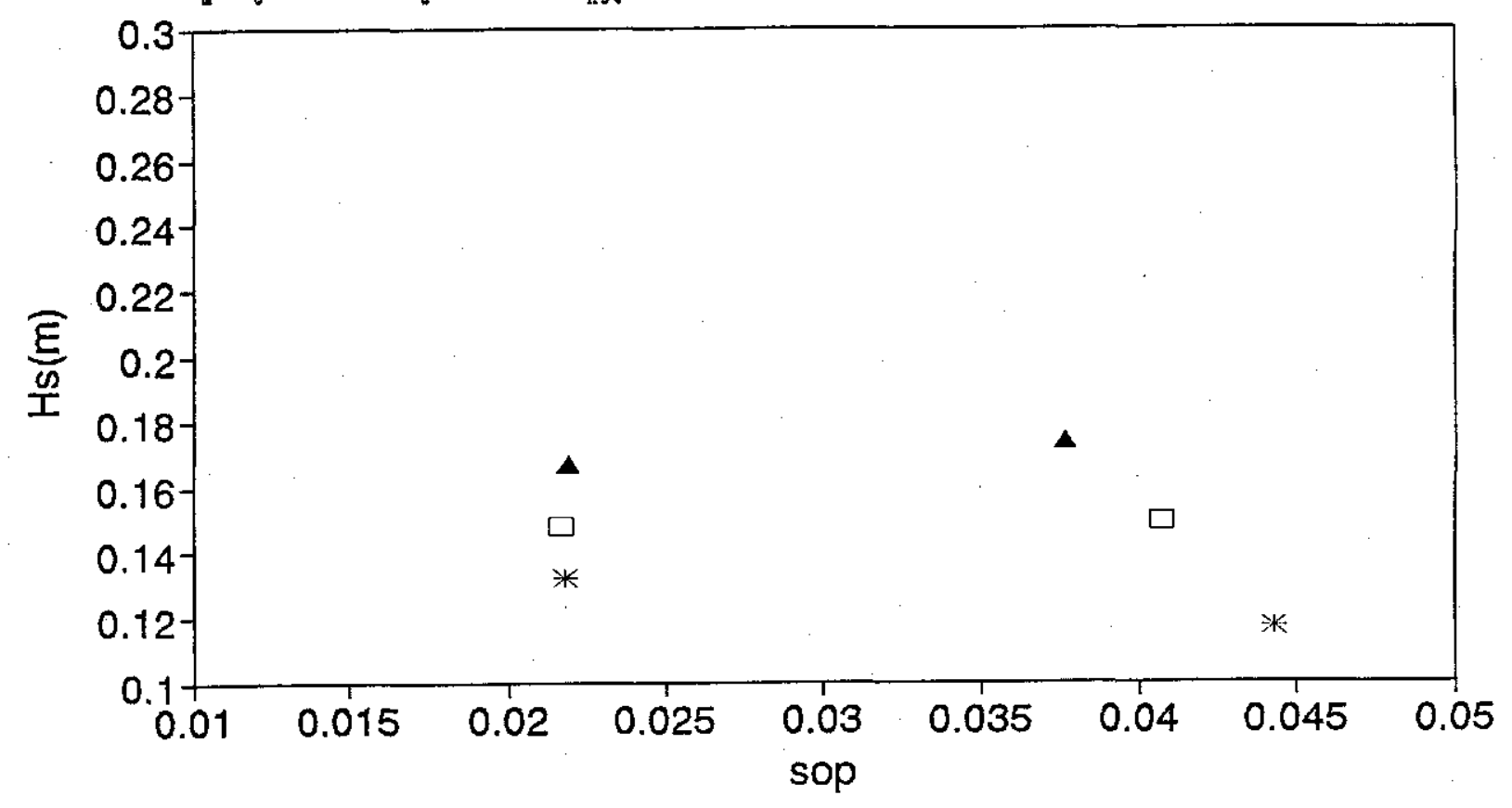

* Nod=0.5 $\square$ Nod=2 $\Delta \quad \mathrm{Nod}=4$ 
significant wave height $H_{s}$ as a function of fictitious wave steepness $s_{o p}$ for fixed damage levels $\mathrm{N}_{\mathrm{d}}$

$h=0.9 \mathrm{~m} h_{1}-h_{2}=0.22 \mathrm{mh}=0.12 \mathrm{~m} \mathrm{D}_{\mathrm{h} 0}=0.025 \mathrm{~m}$

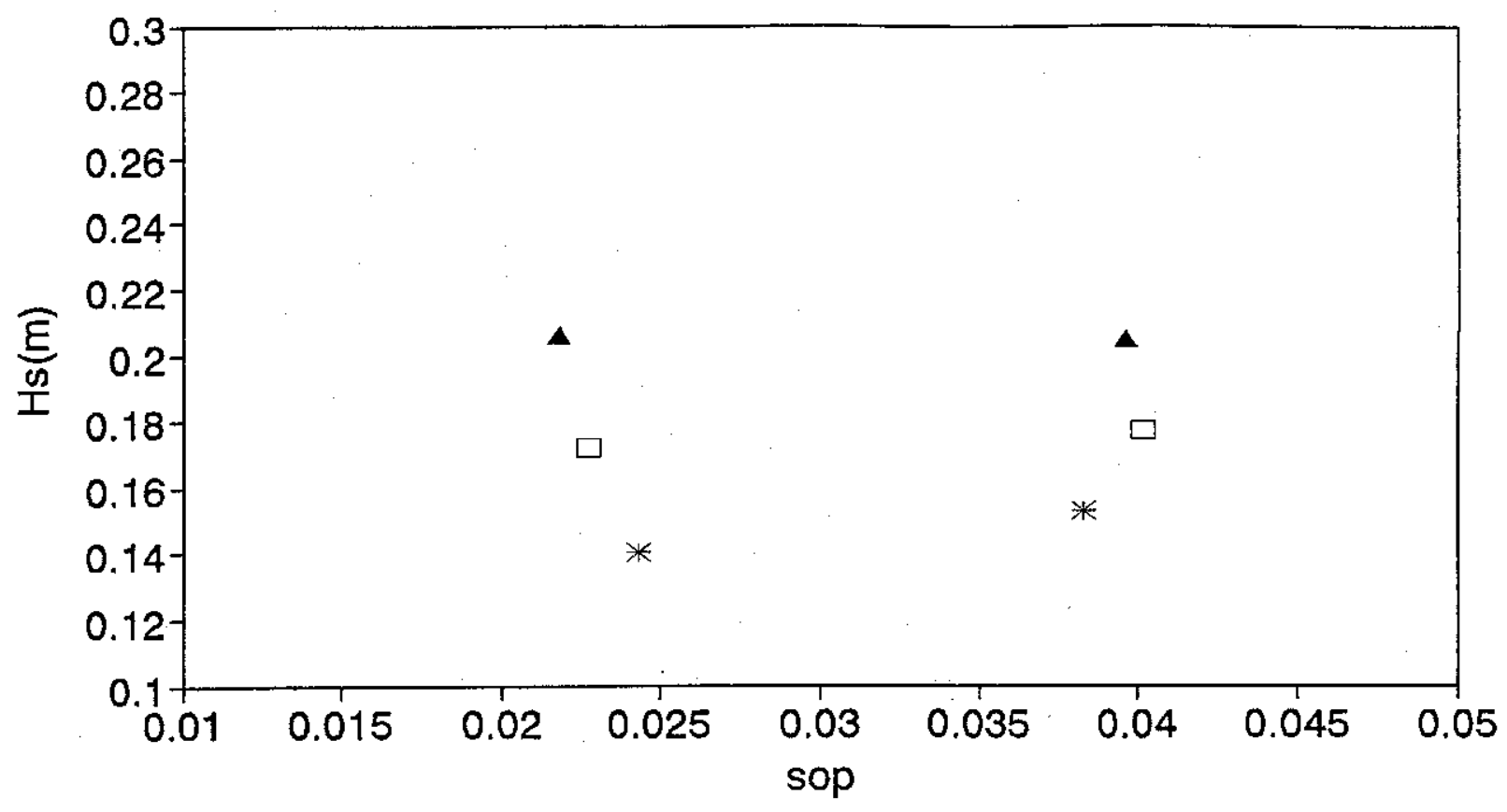

* Nod=0.5 $\square \quad \mathrm{Nod}=2 \quad \Delta \quad \mathrm{Nod}=4$

$h=0.9 m h_{a}-h_{2}=0.15 m h_{q}=0.20 m h_{h 0}=0.025 m$

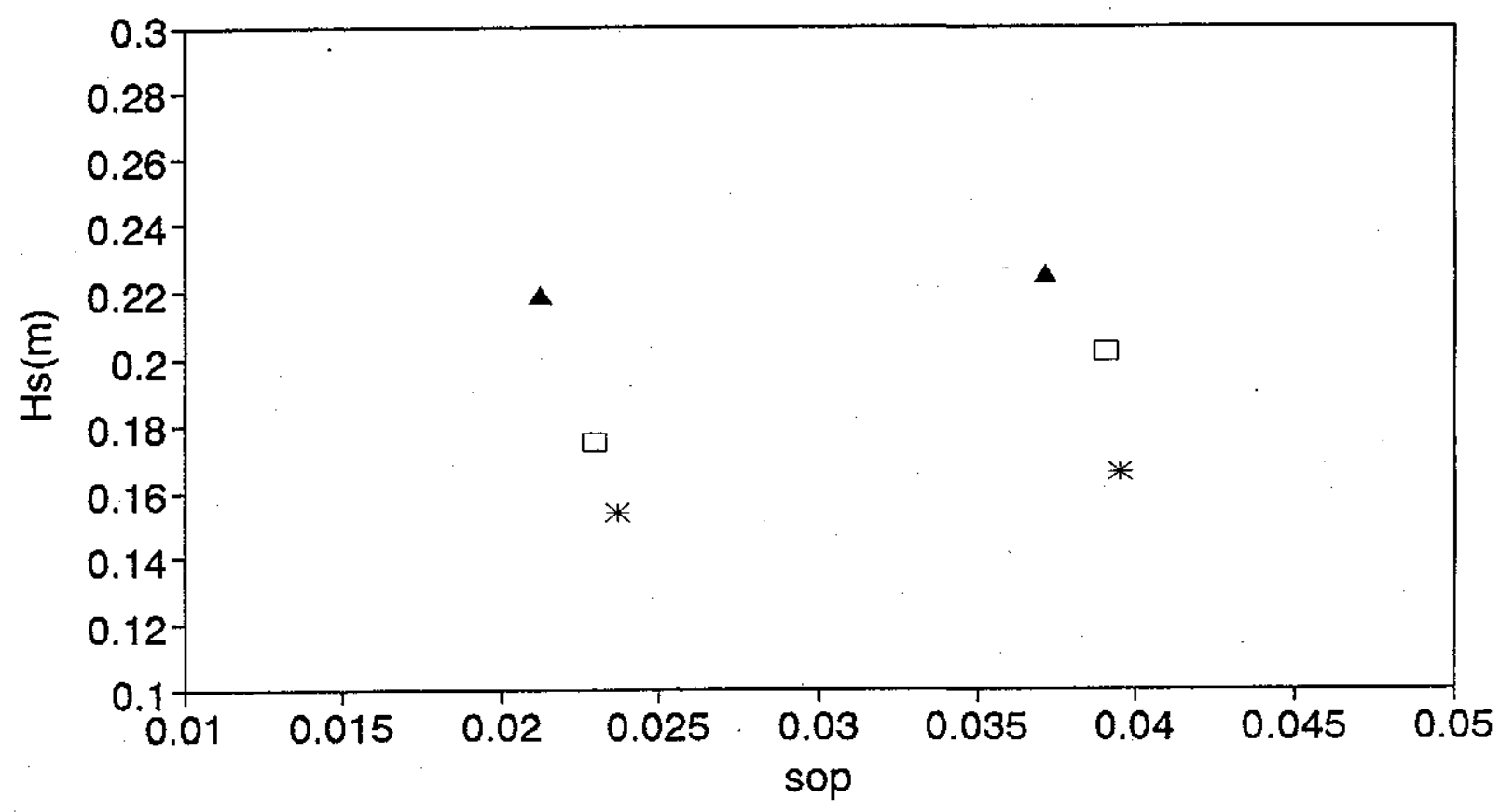

* Nod=0.5 $\square \quad \mathrm{Nod}=2 \quad \Delta \quad \mathrm{Nod}=4$ 
significant wave height $H_{s}$ as a function of fictitious wave steepness $\mathrm{S}_{\text {op }}$ for fixed damage levels $\tilde{N}_{d}$

$h=0.9 m h_{-}-h_{2}=0.15 m h_{2}=0.20 m h_{h 50}=0.040 m$

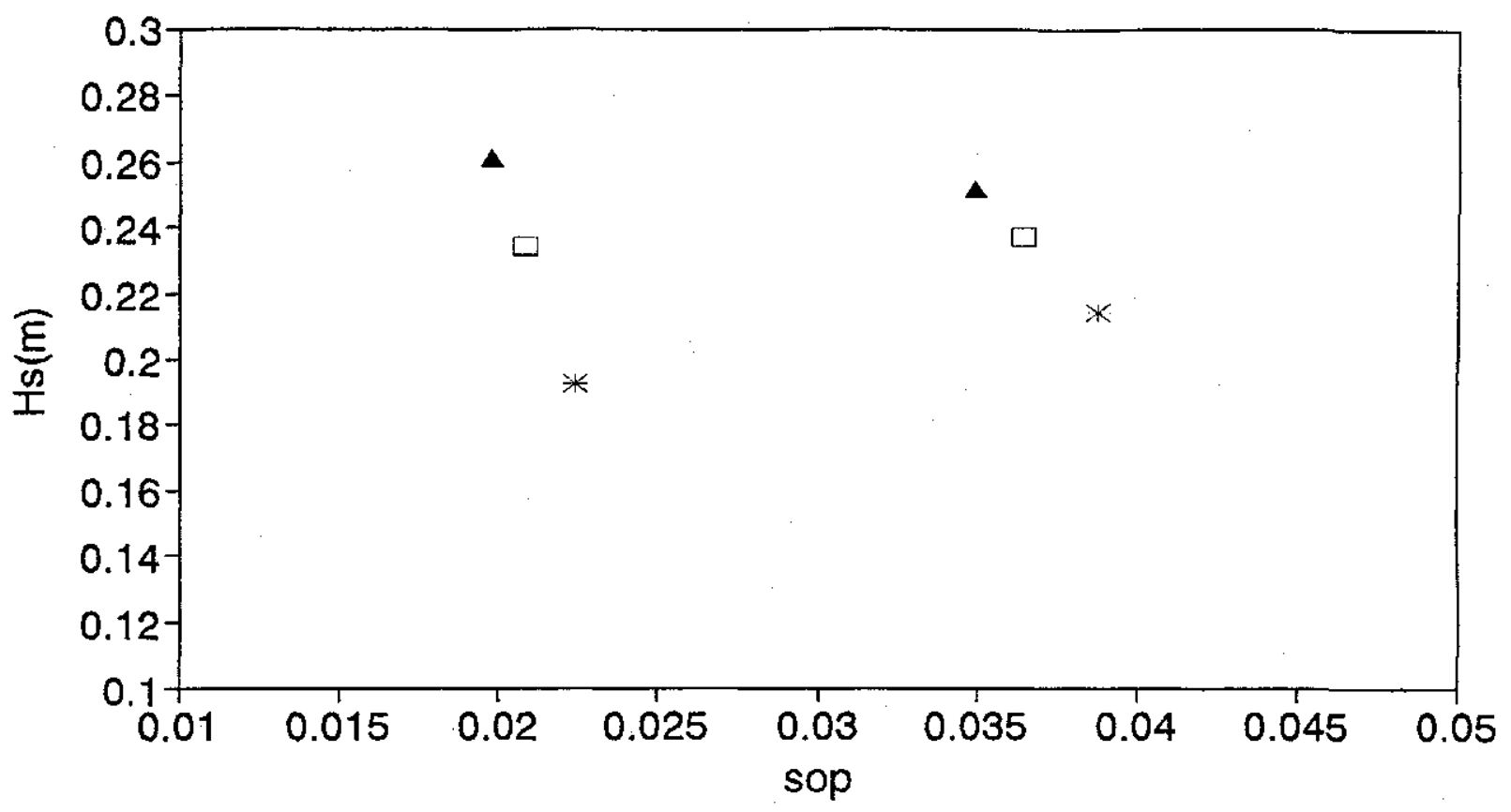

* Nod=0.5 $\square \quad$ Nod=2 $\Delta \quad$ Nod $=4$

$h=0.9 m h_{2}-h_{t}=0.15 m h_{t}=0.30 m D_{h 0}=0.025 m$

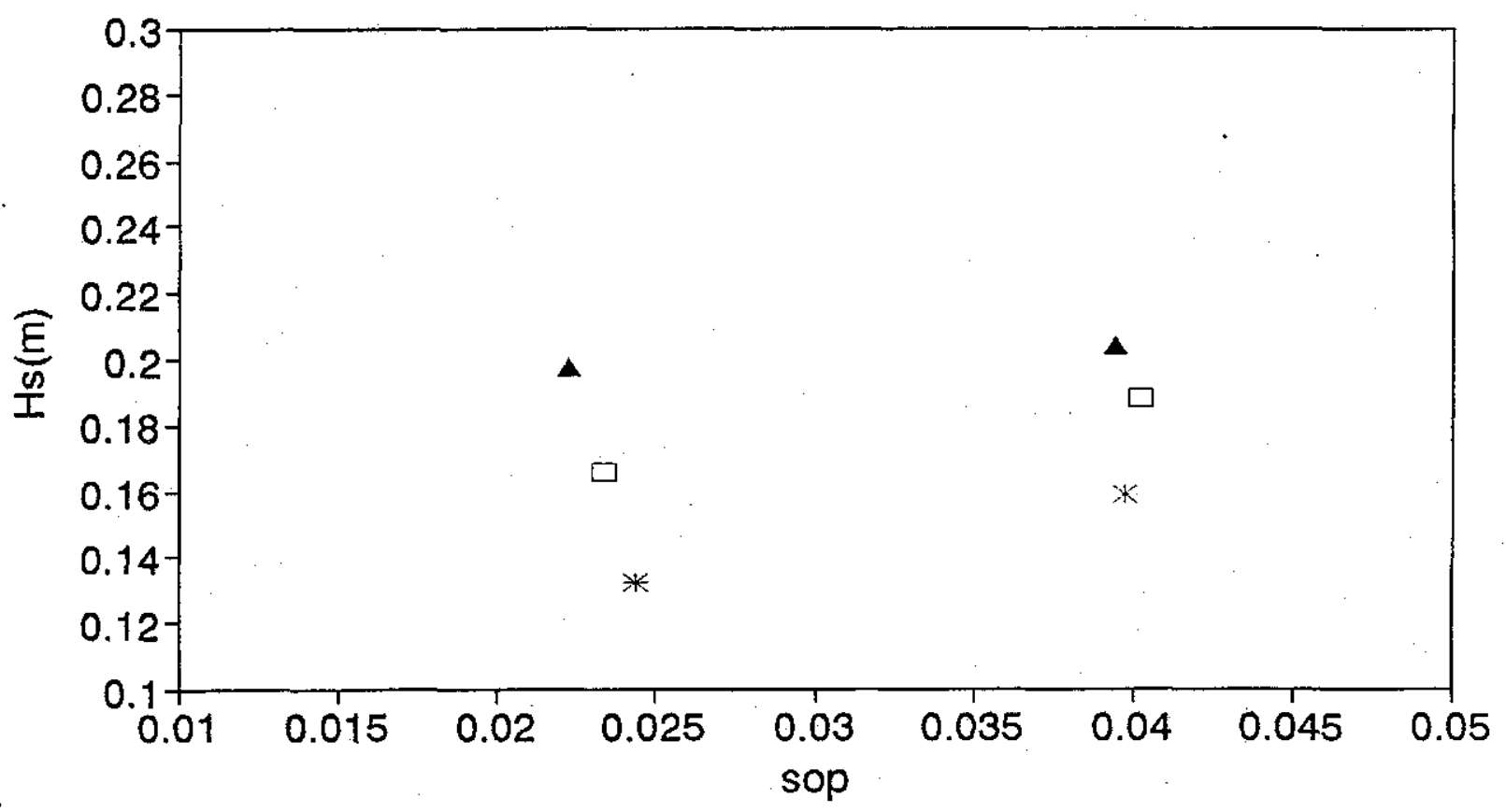

* Nod=0.5 $\square \quad \mathrm{Nod}=2 \quad \Delta \quad \mathrm{Nod}=4$

Figure $26 \mathrm{a}$ and $\mathrm{b}$ 
damage level $\mathrm{N}_{\text {od }}$ as a function of significant wave height $\mathrm{H}_{s}$ for fixed wave steepness $\mathrm{S}_{\text {op }}$

$h=0.7 \mathrm{~m} h_{\mathrm{i}}-h_{t}=0.08 \mathrm{~m} b_{t}=0.12 m D_{a 50}=0.017 \mathrm{~m}$

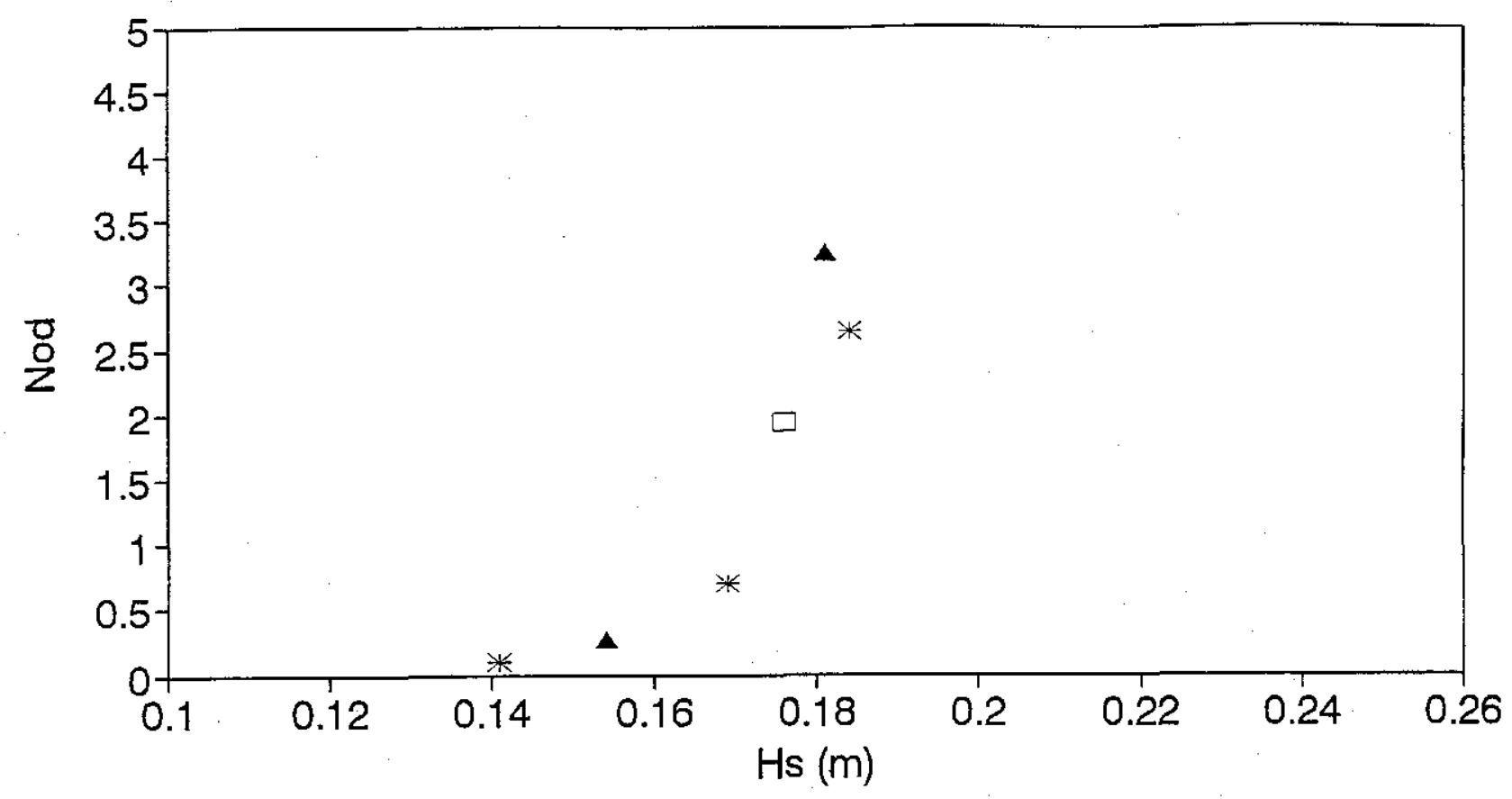

* $\mathrm{sop}=0.04 \square \mathrm{sop}=0.03 \quad \wedge \mathrm{sop}=0.02$

$h=0.7 \mathrm{~m} \mathrm{~h}_{\mathrm{i}}-\mathrm{h}_{\mathrm{t}}=0.08 \mathrm{~m} \mathrm{~b}_{\mathrm{t}}=0.12 \mathrm{~m} \mathrm{~B}_{\mathrm{a} 50}=0.035 \mathrm{~m}$

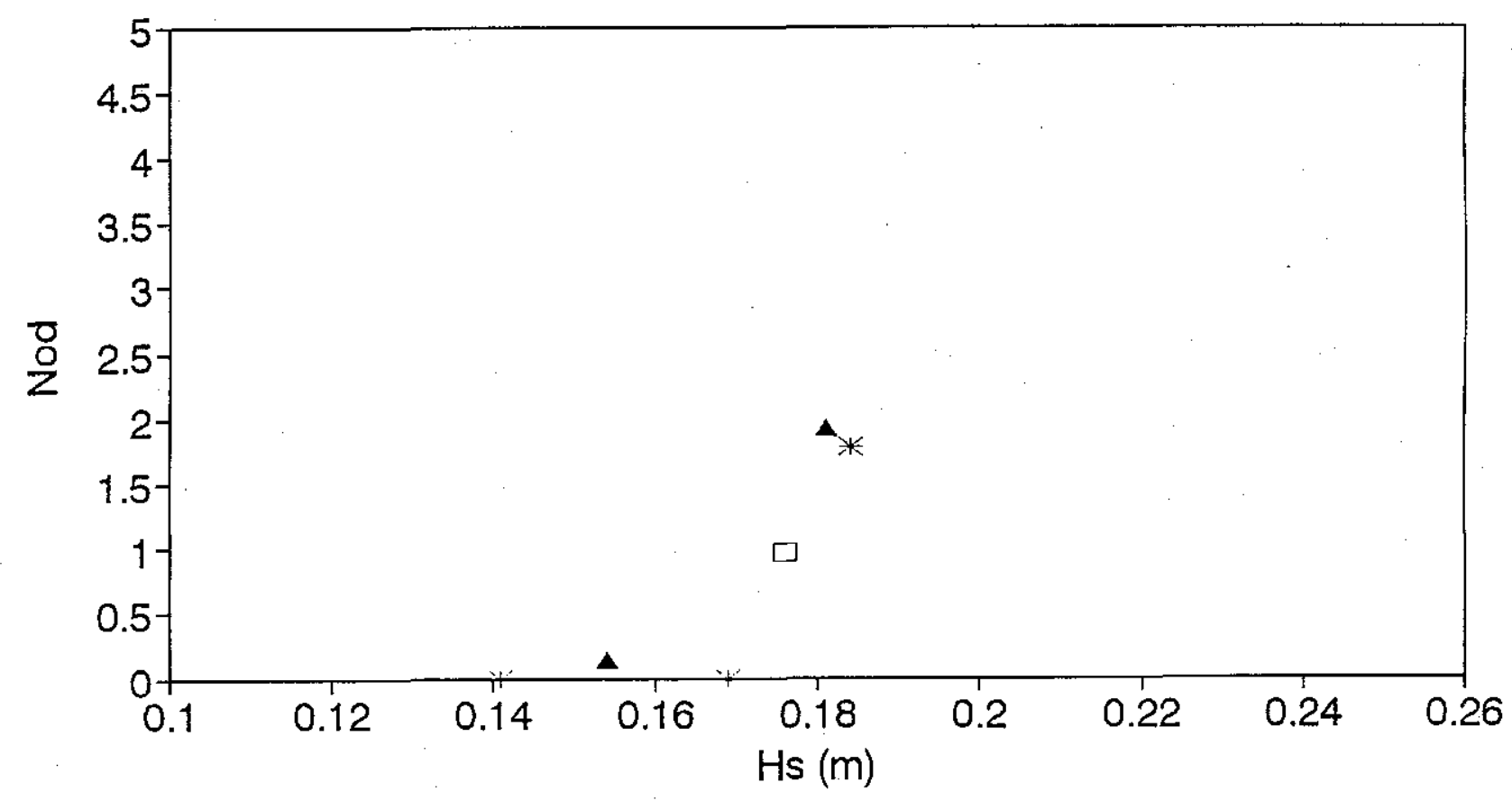

* $\mathrm{sop}=0.04 \square \mathrm{sop}=0.03 \wedge \mathrm{sop}=0.02$

Figure $27 \mathrm{a}$ and $\mathrm{b}$ 
damage level $\mathrm{N}_{o d}$ as a function of significant wave height $\mathrm{H}_{s}$ for fixed wave steepness $\mathrm{s}_{\text {op }}$

$h=0.7 \mathrm{~m} h_{t}-h_{t}=0.15 \mathrm{~m} b_{t}=0.12 m D_{n s 0}=0.040 \mathrm{~m}$

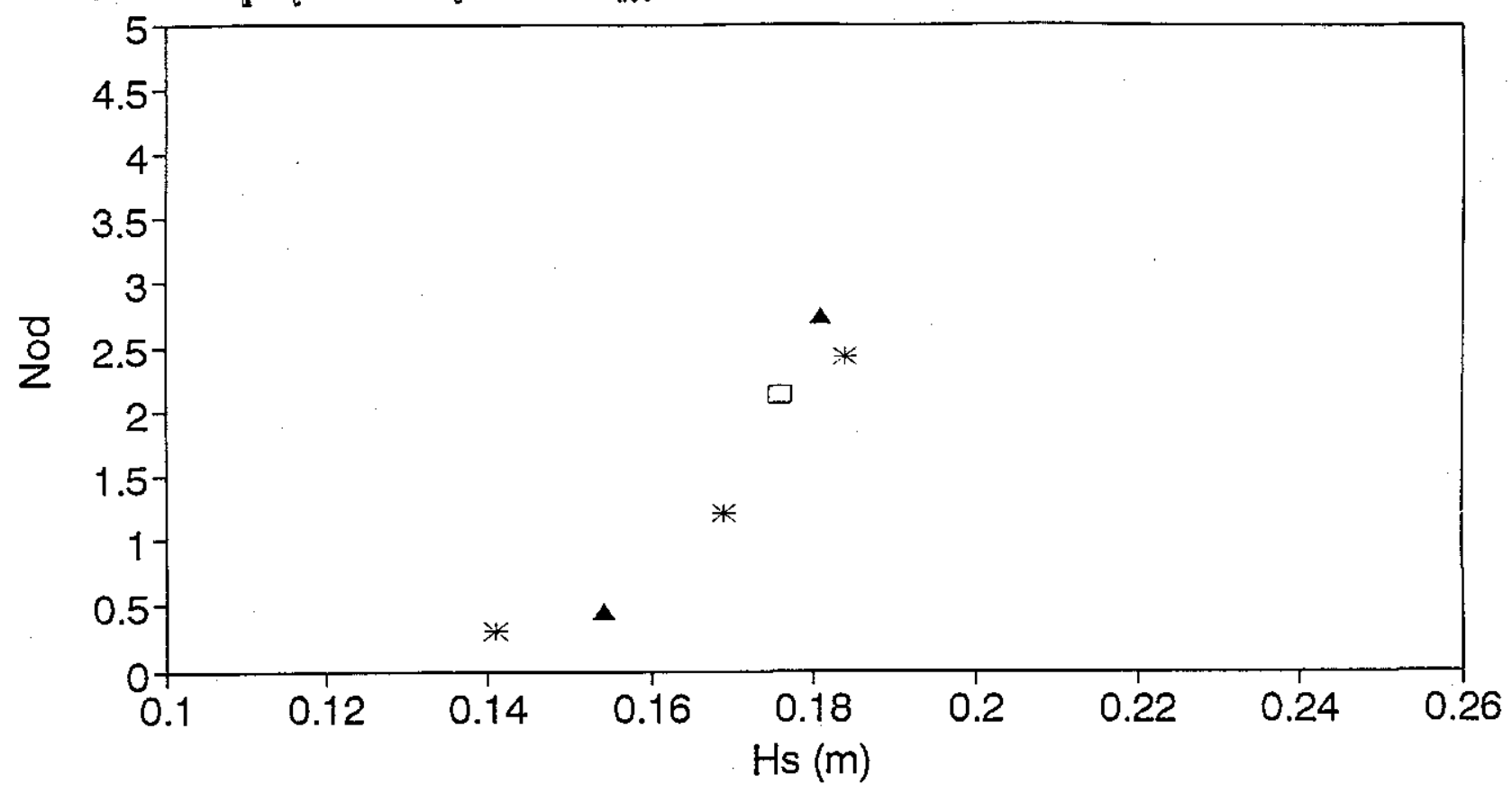

* $\mathrm{sop}=0.04 \square \mathrm{sop}=0.03$ A $\mathrm{sop}=0.02$

$h=0.9 m h_{t}-h_{t}=0.08 m h_{t}=0.12 m a_{h 0}=0.017 m$

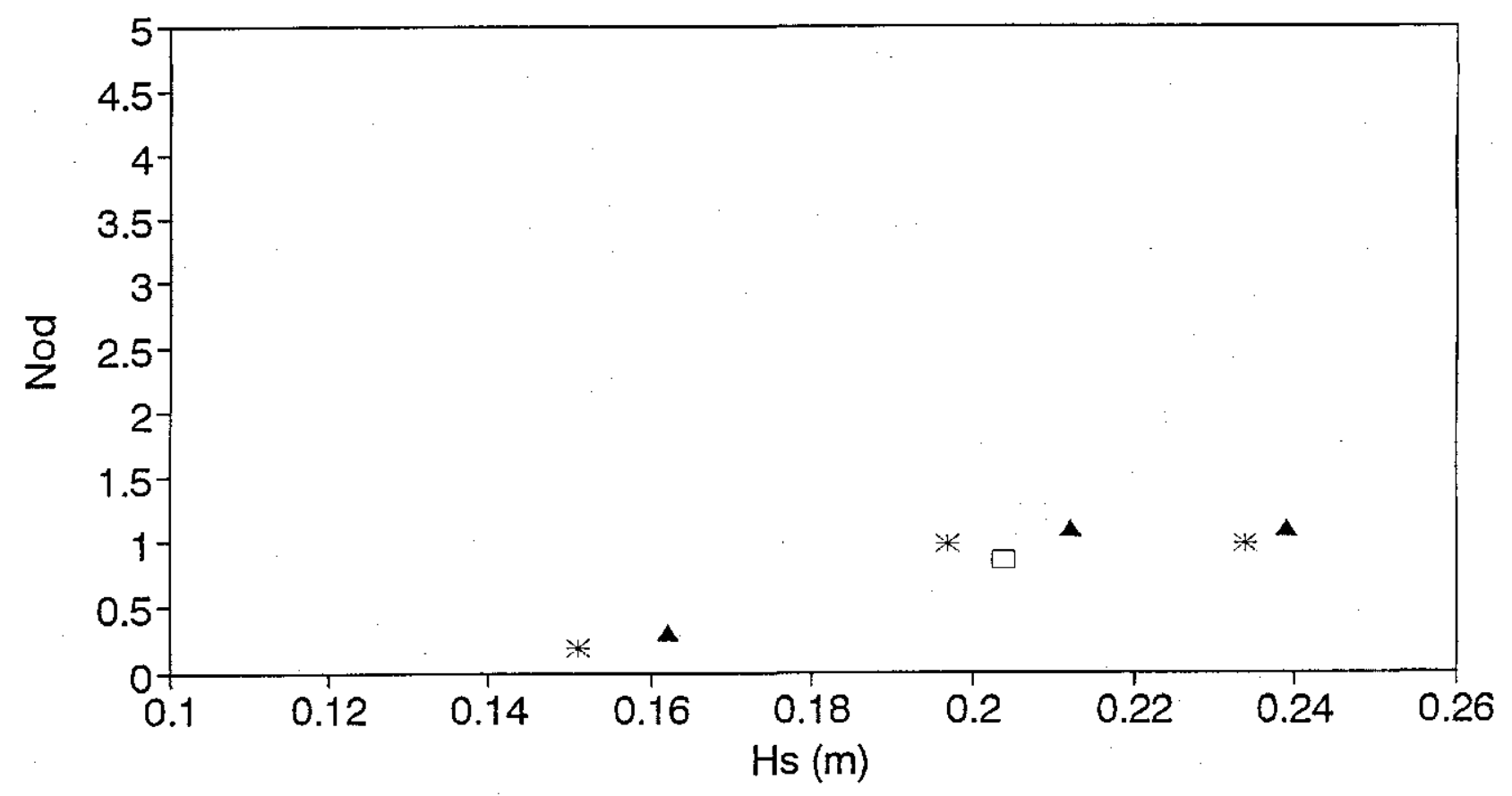

* $\mathrm{sop}=0.04 \square \mathrm{sop}=0.03$ A $\mathrm{sop}=0.02$ 
significant wave height $H_{s}$ as a function of toe wiath $b_{t}$ for fixed damage levels $N_{\text {od }}$

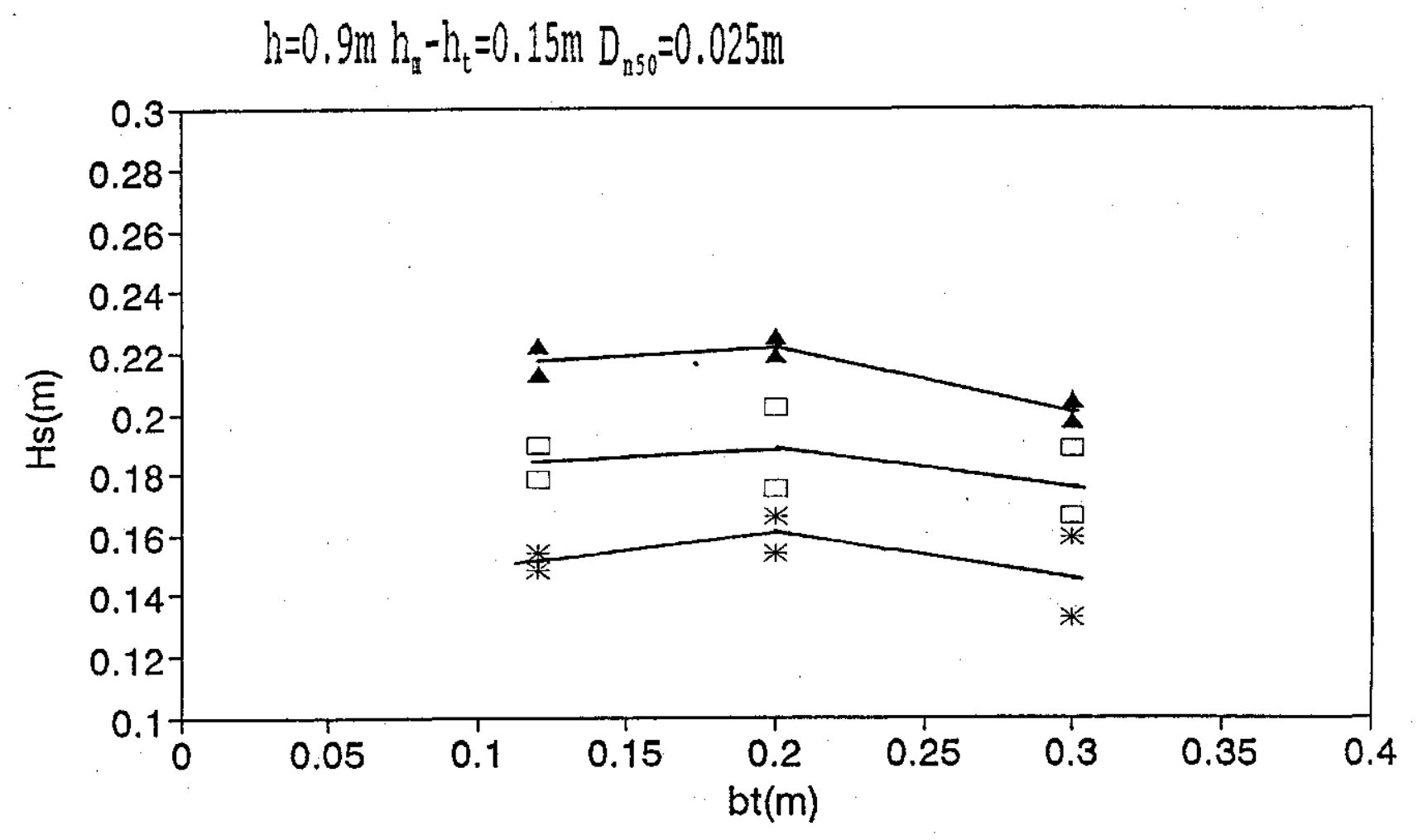

* Nod=0.5 $\square \quad$ Nod $=2 \quad \Delta \quad$ Nod $=4$ 
significant wave height $\mathrm{H}_{\mathrm{s}}$ as a function of toe width $\mathrm{b}_{\mathrm{t}}$ for fixed damage levels $N_{\text {od }}$

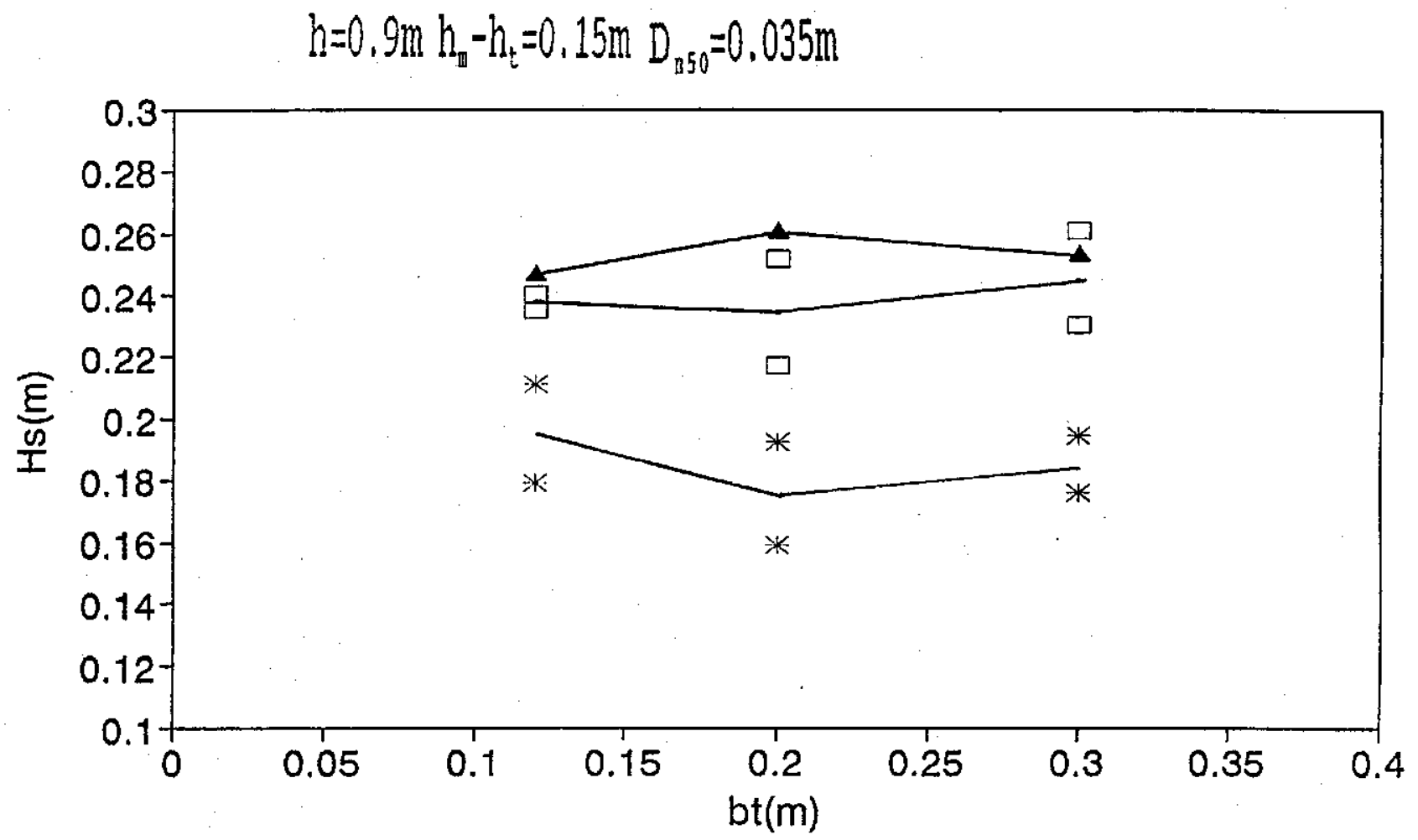

* Nod=0.5 $\square \quad \mathrm{Nod}=2 \quad \Delta \quad \mathrm{Nod}=4$ 
significant wave height $\mathrm{H}_{\mathrm{s}}$ as a function of toe width $\mathrm{b}_{\mathrm{t}}$ for fixed damage levels $\mathrm{Nod}_{\mathrm{d}}$ $h=0.9 m h_{2}-h_{2}=0.15 m D_{n 50}=0.040 m$

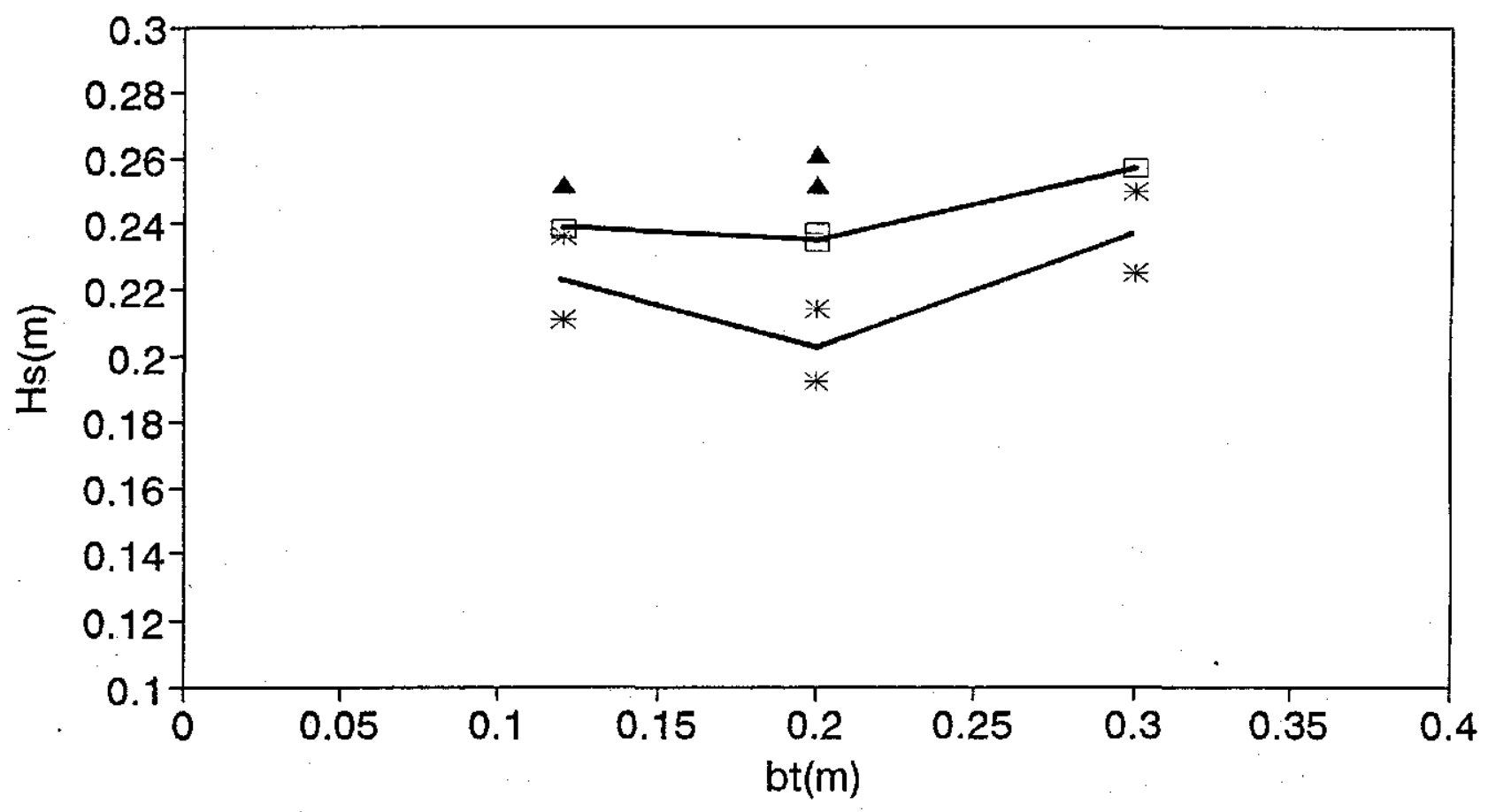

* Nod=0.5 $\square \quad \mathrm{Nod}=2 \quad \Delta \quad \mathrm{Nod}=4$ 
significant wave height $\mathrm{H}_{s}$ as a function of shallow water depth $h_{u}$ for fixed damage levels $\mathrm{N}_{o \mathrm{~d}}$

$h_{\mathrm{a}}-h_{t}=0.08 \mathrm{~m} D_{\mathrm{a} 50}=0.017 \mathrm{~m}$

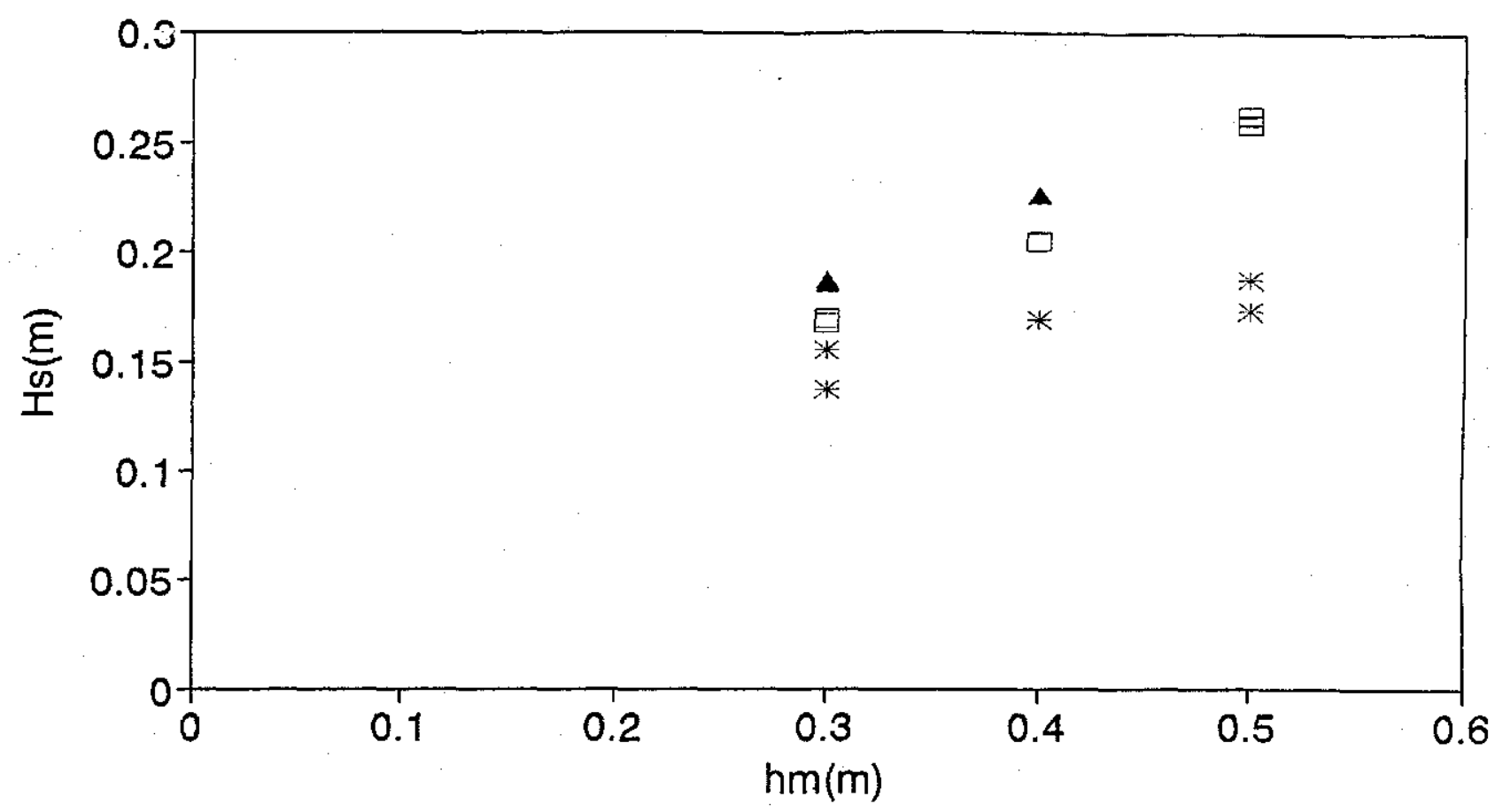

* Nod=0.5 $\square \quad \mathrm{Nod}=2 \quad \wedge \quad \mathrm{Nod}=4$

$h_{\mathrm{at}}-h_{t}=0.08 \mathrm{~m} \mathrm{D}_{\mathrm{ns0}}=0.025 \mathrm{~m}$

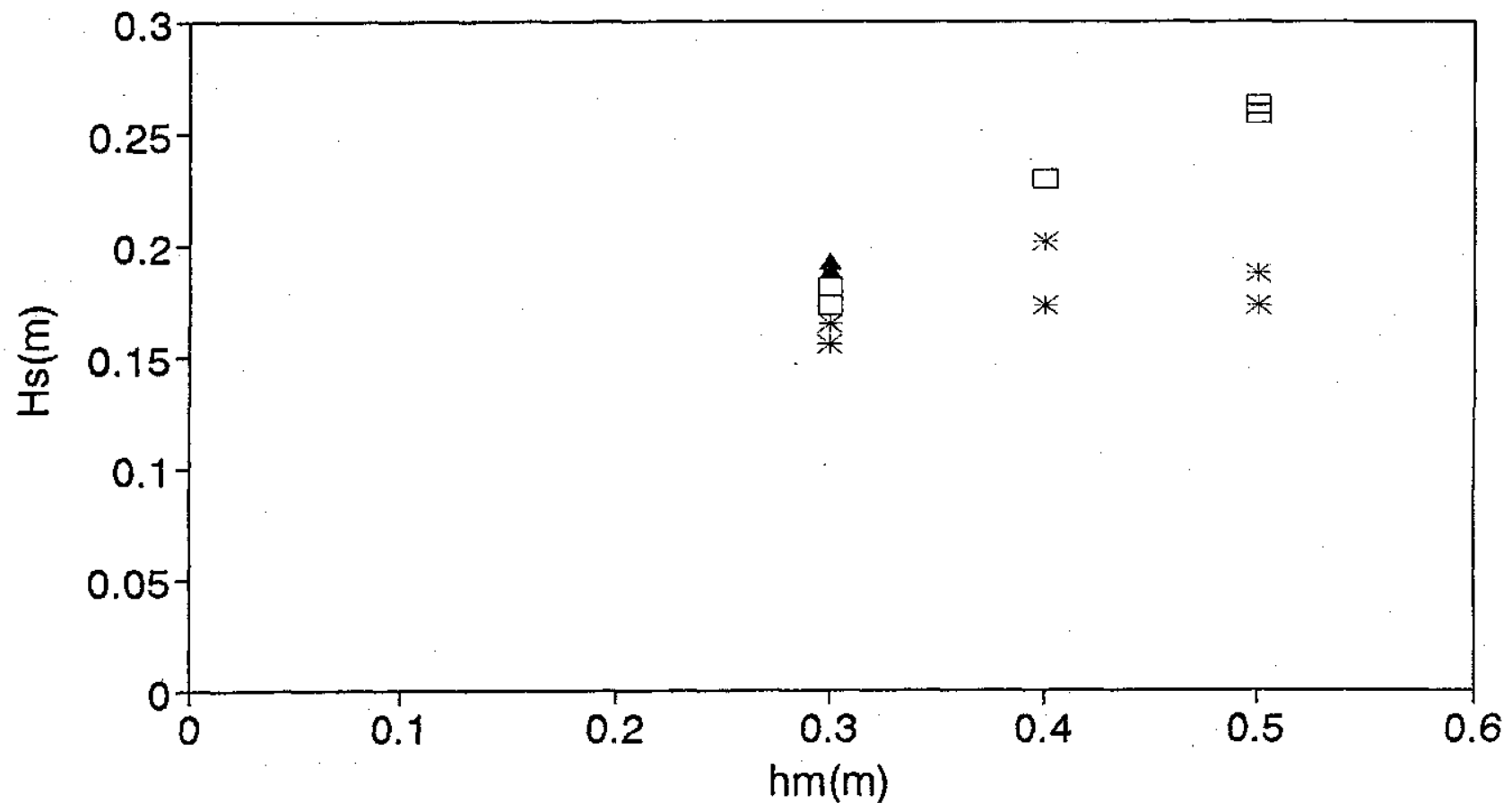

* Nod=0.5 $\square \quad \mathrm{Nod}=2 \quad \Delta \quad \mathrm{Nod}=4$ 
significant wave height $H_{s}$ as a function of shallow water depth $h_{\mathrm{a}}$ for fixed damage levels $\mathrm{N}_{\text {od }}$

$h_{\mathrm{a}}-h_{t}=0.15 \mathrm{~m}_{\mathrm{ns0}}=0.025 \mathrm{~m}$

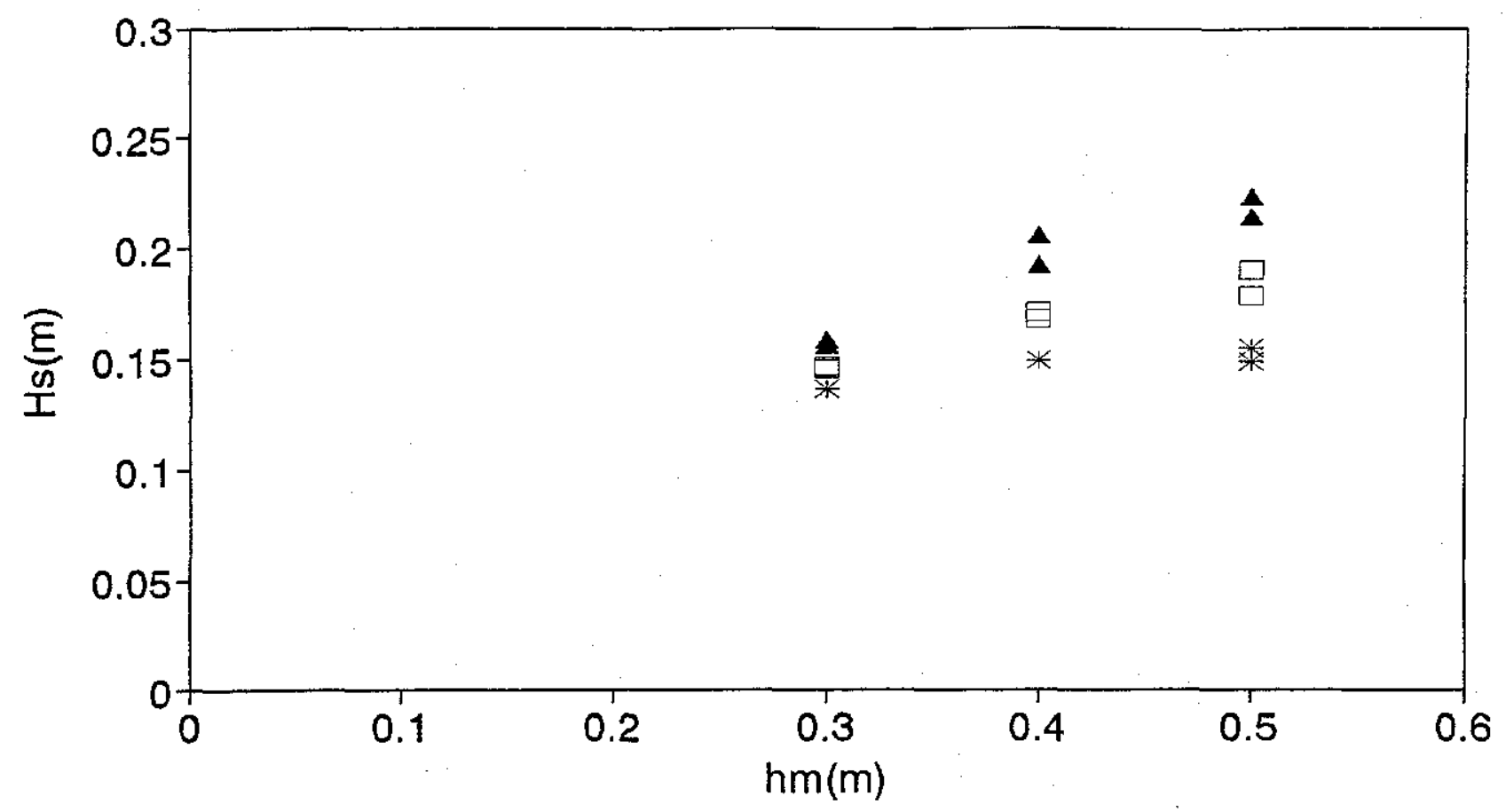

* Nod=0.5 $\square \quad \mathrm{Nod}=2 \quad \Delta \quad \mathrm{Nod}=4$

$h_{2}-h_{t}=0.15 m D_{n s 0}=0.040 m$

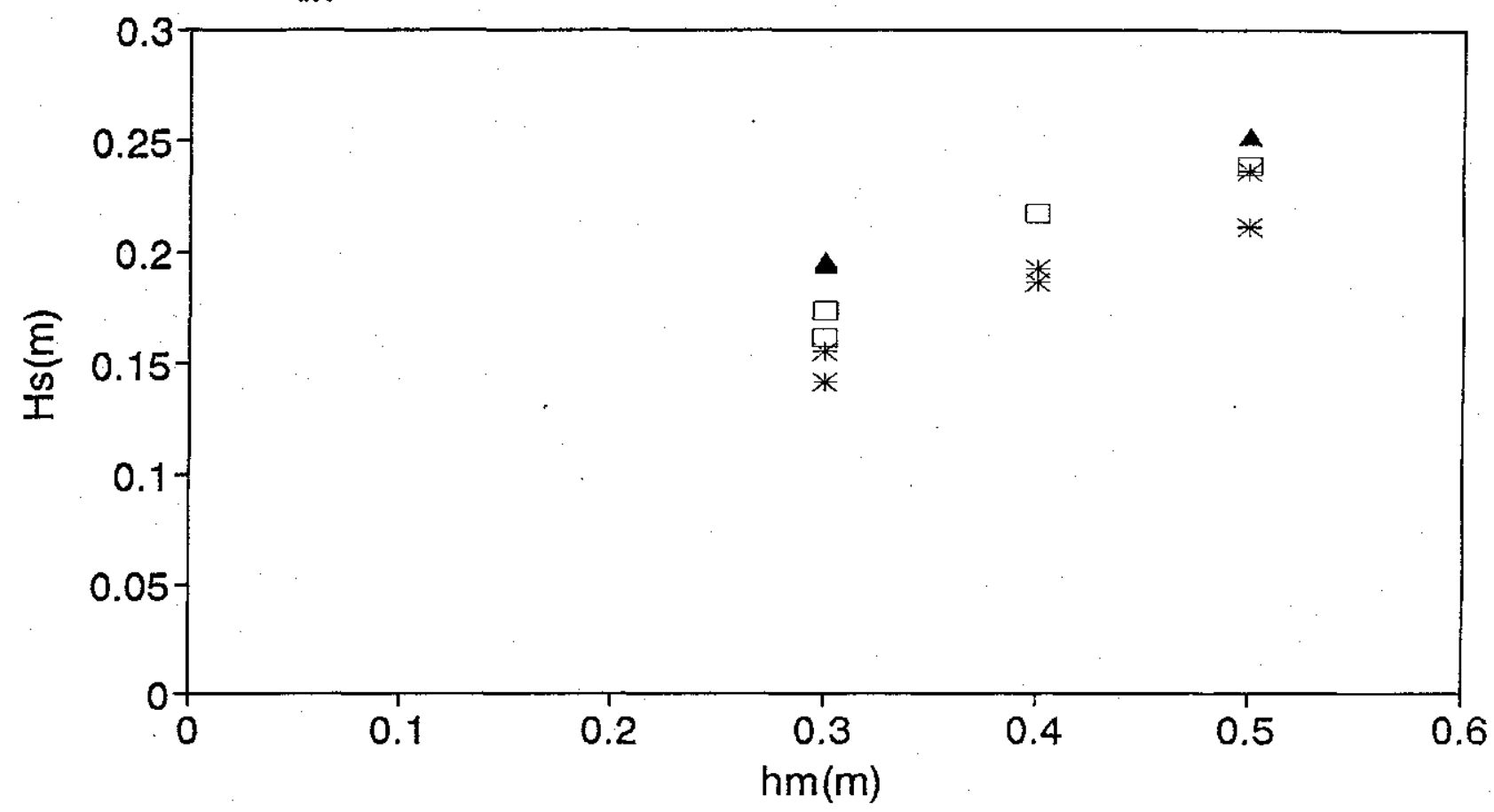

* Nod=0.5 $\square \quad \mathrm{Nod}=2 \quad \Delta \quad \mathrm{Nod}=4$ 
significant wave height $H_{3}$ as a function of toe heigth $h_{n}-h_{t}$ for fixed damage levels $\mathrm{N}_{o d}$

$h=0.8 \mathrm{~m} D_{n 55}=0.025 \mathrm{~m}$

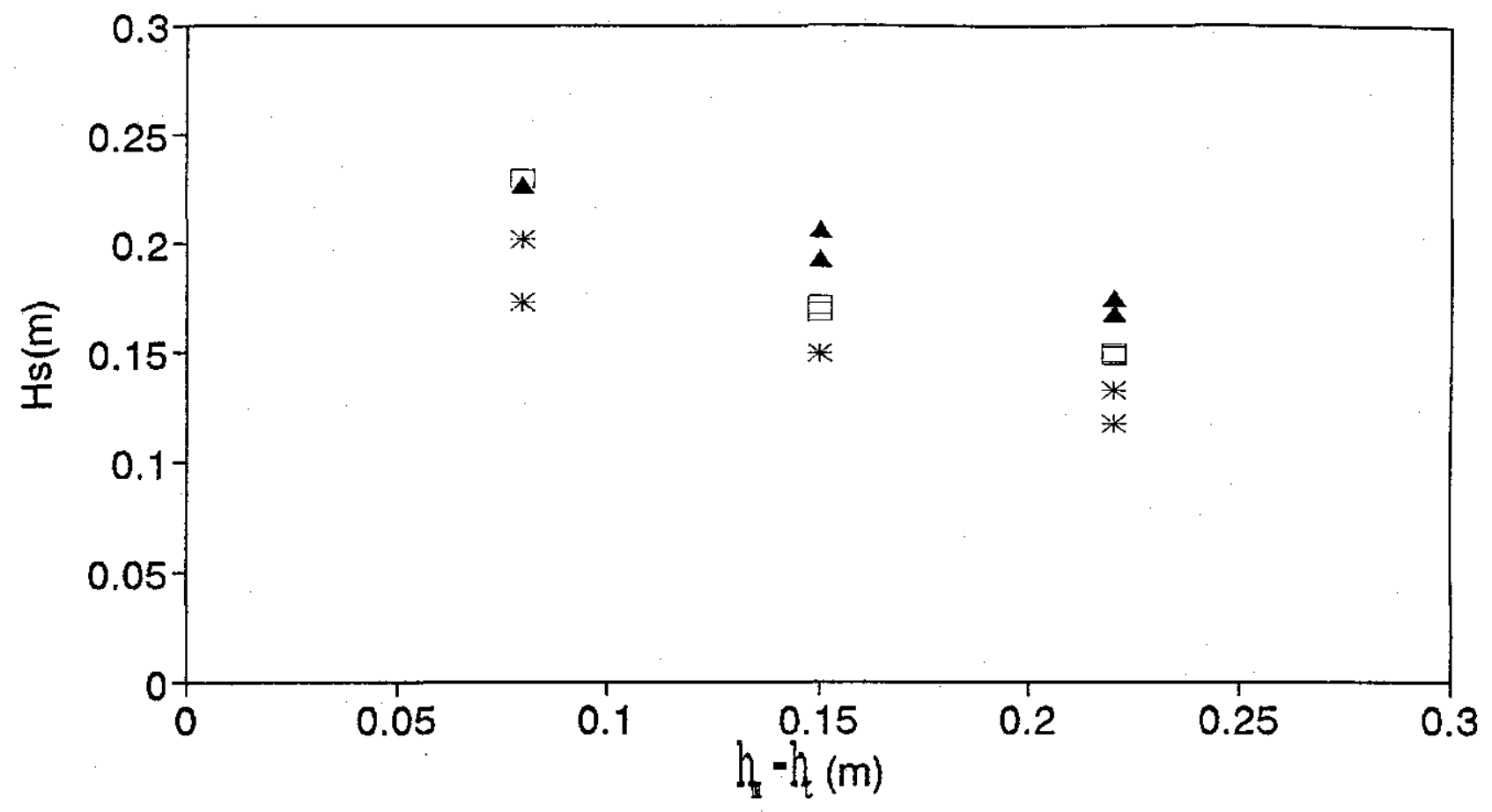

* Nod=0.5 $\square \quad \mathrm{Nod}=2 \quad \Delta \quad \mathrm{Nod}=4$

$h=0.9 m D_{n s 5}=0.025 \mathrm{~m}$

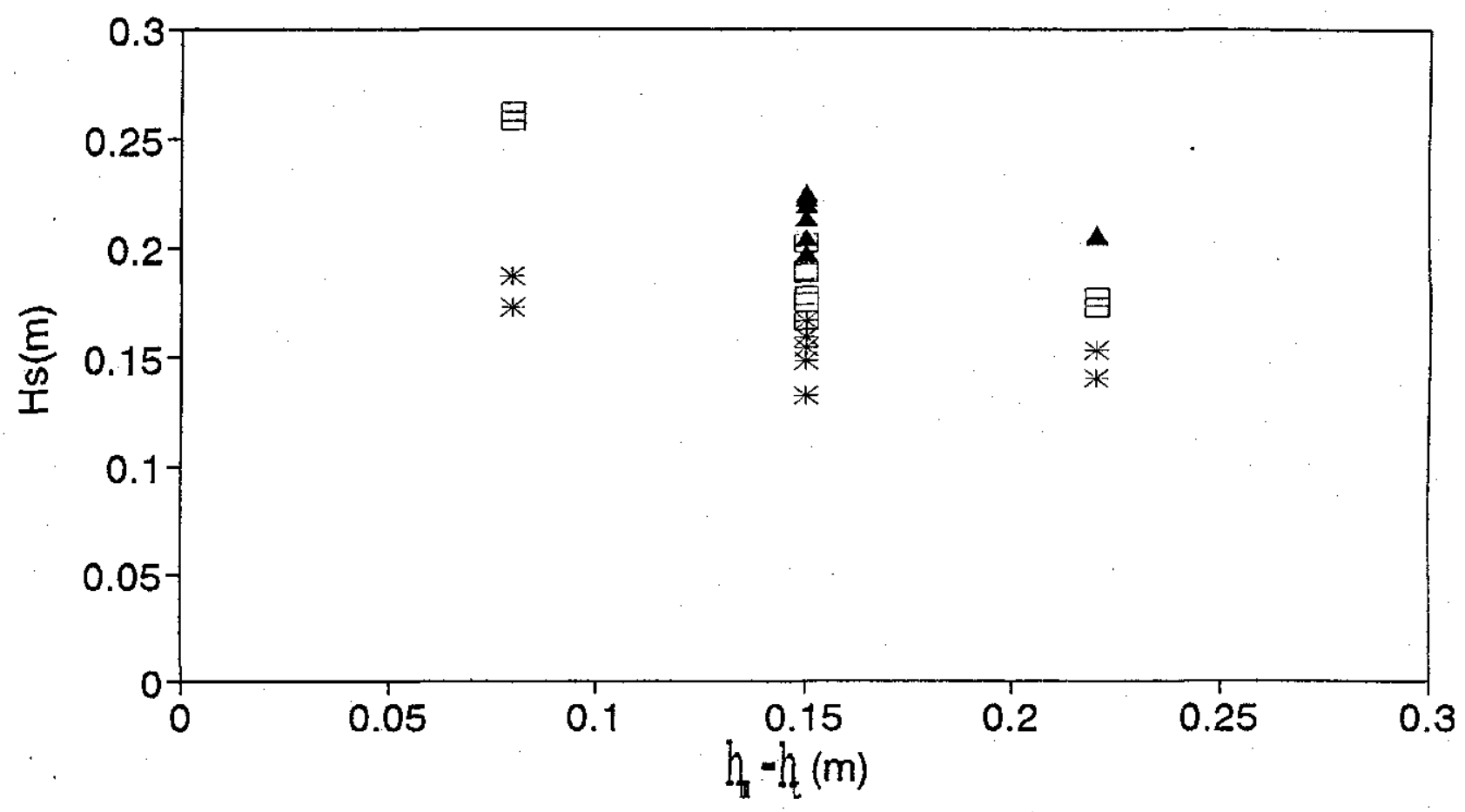

* Nod=0.5 $\square \quad \mathrm{Nod}=2 \quad \Delta \quad \mathrm{Nod}=4$ 
significant wave height $H_{s}$ as a function of stone diameter $D_{n 50}$ for fixed damage levels $\mathrm{N}_{o d}$

$h=0.7 m h_{1}-h_{t}=0.08 m$

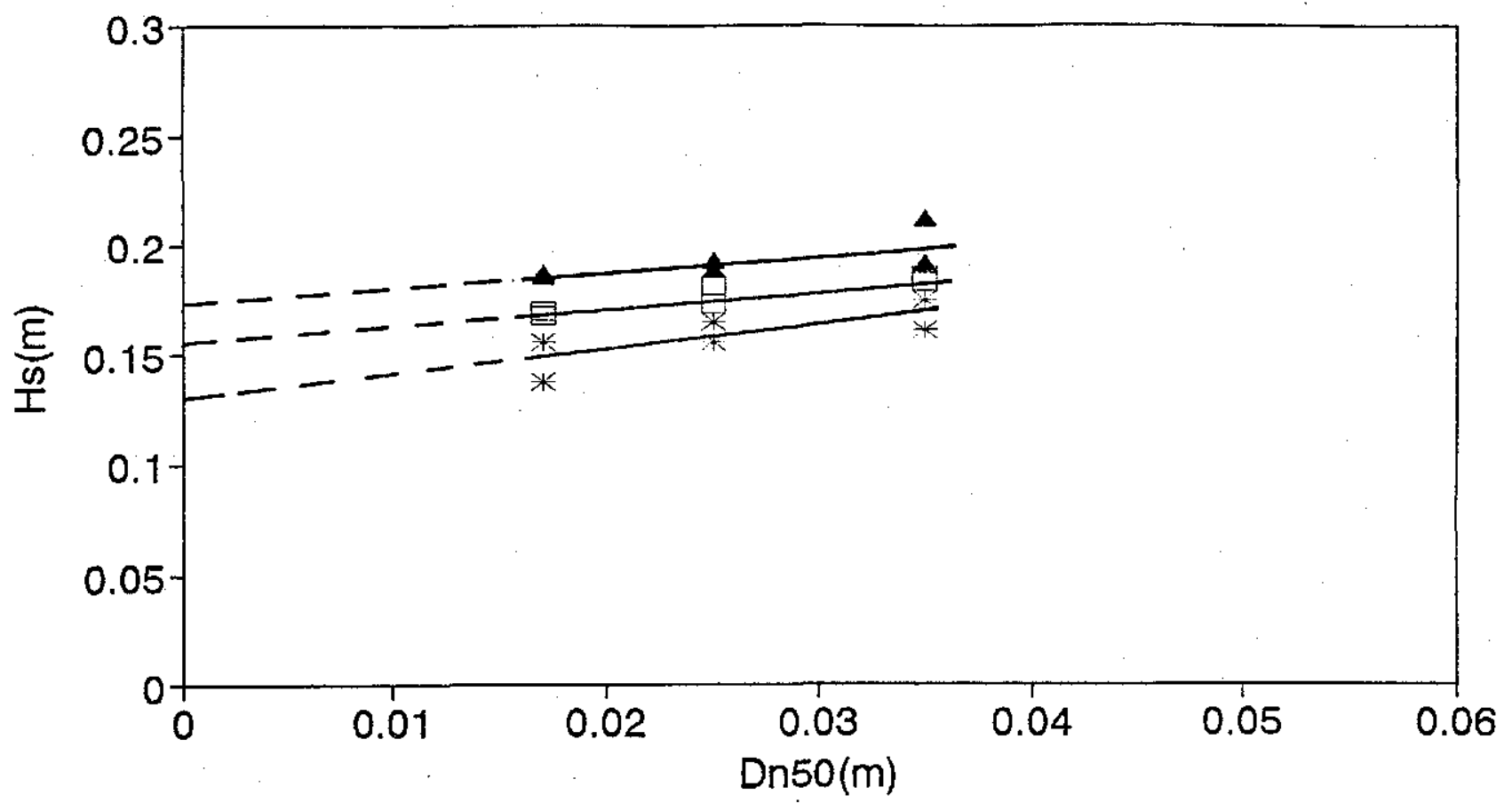

* Nod=0.5 $\square \quad$ Nod=2 $\Delta \quad$ Nod $=4$

$h=0.7 m h_{-}-h_{t}=0.15 m$

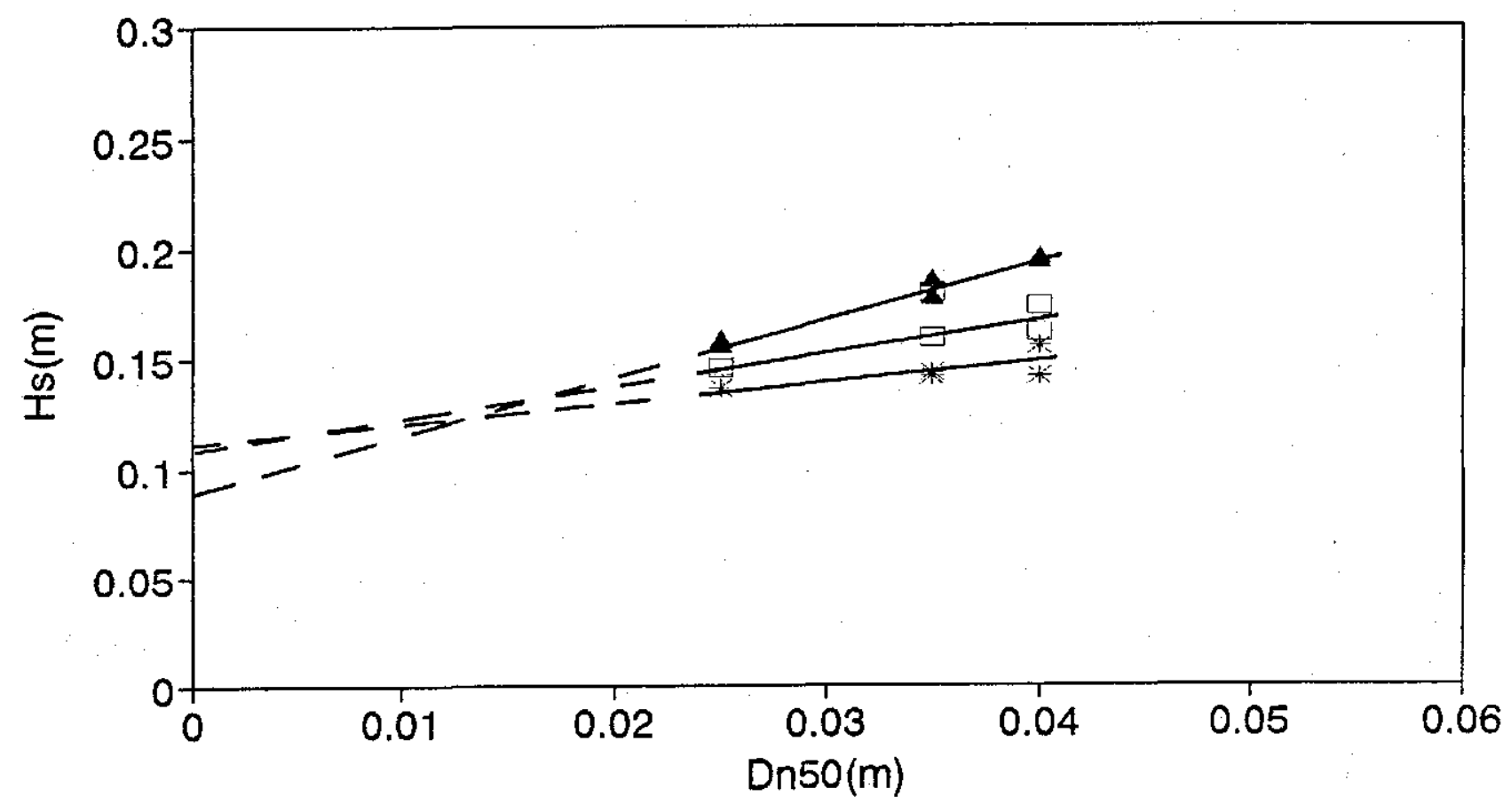

* Nod=0.5 $\square$ Nod=2 $\Delta$ Nod $=4$ 
significant wave height $H_{3}$ as a function of stone diameter $D_{n 50}$ for fixed damage levels $\mathrm{N}_{\mathrm{do}}$

$h=0.9 m h_{n}-h_{t}=0.15 m$

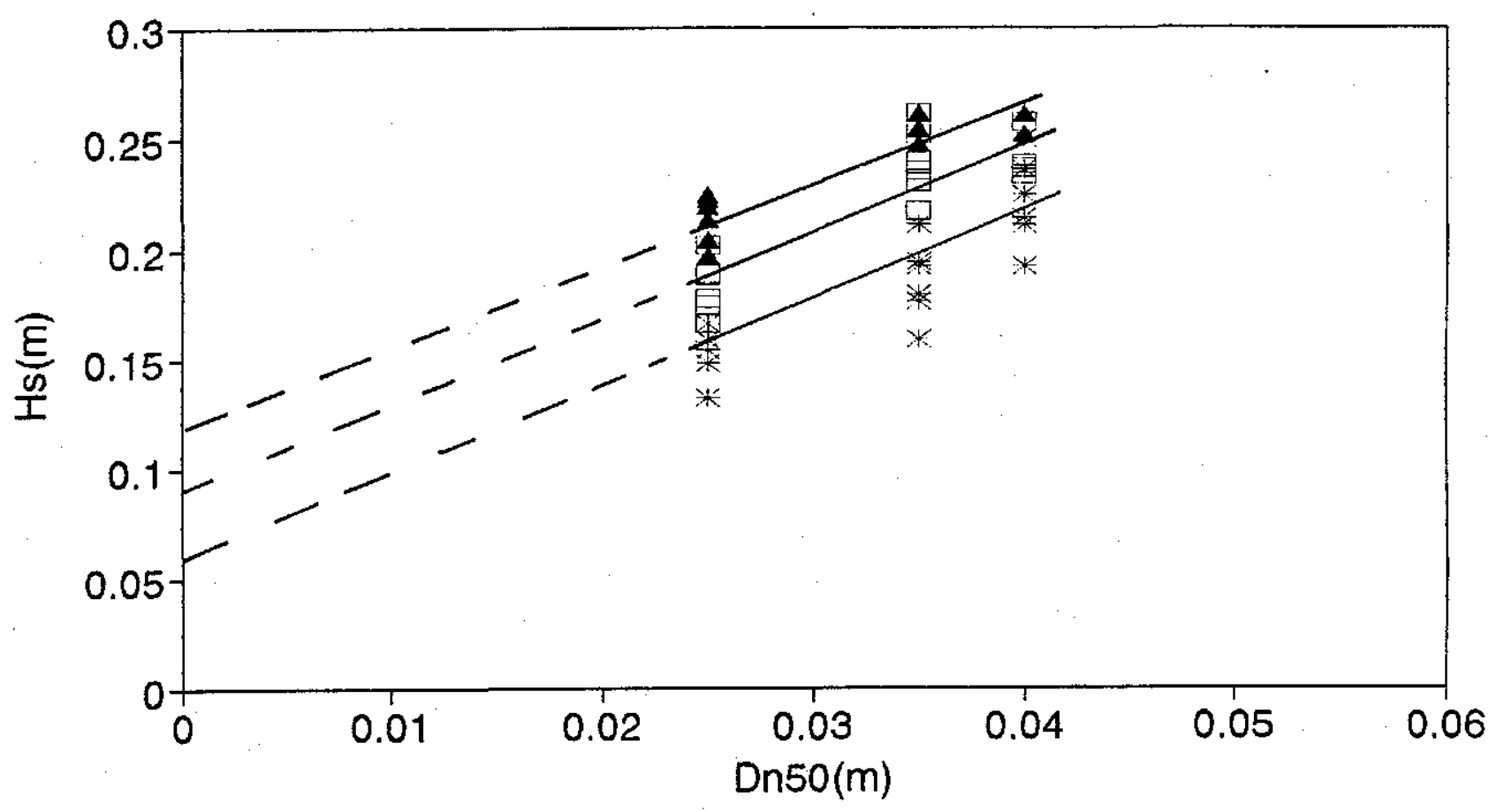

* Nod=0.5 $\square \quad \mathrm{Nod}=2 \quad \Delta \quad \mathrm{Nod}=4$ 
significant wave height $H_{5}$ as a function of stone diameter $D_{n 50}$ for fixed damage levels $\mathrm{N}_{\mathrm{do}}$

$h=0.8 m h-h_{2}=0.22 m$

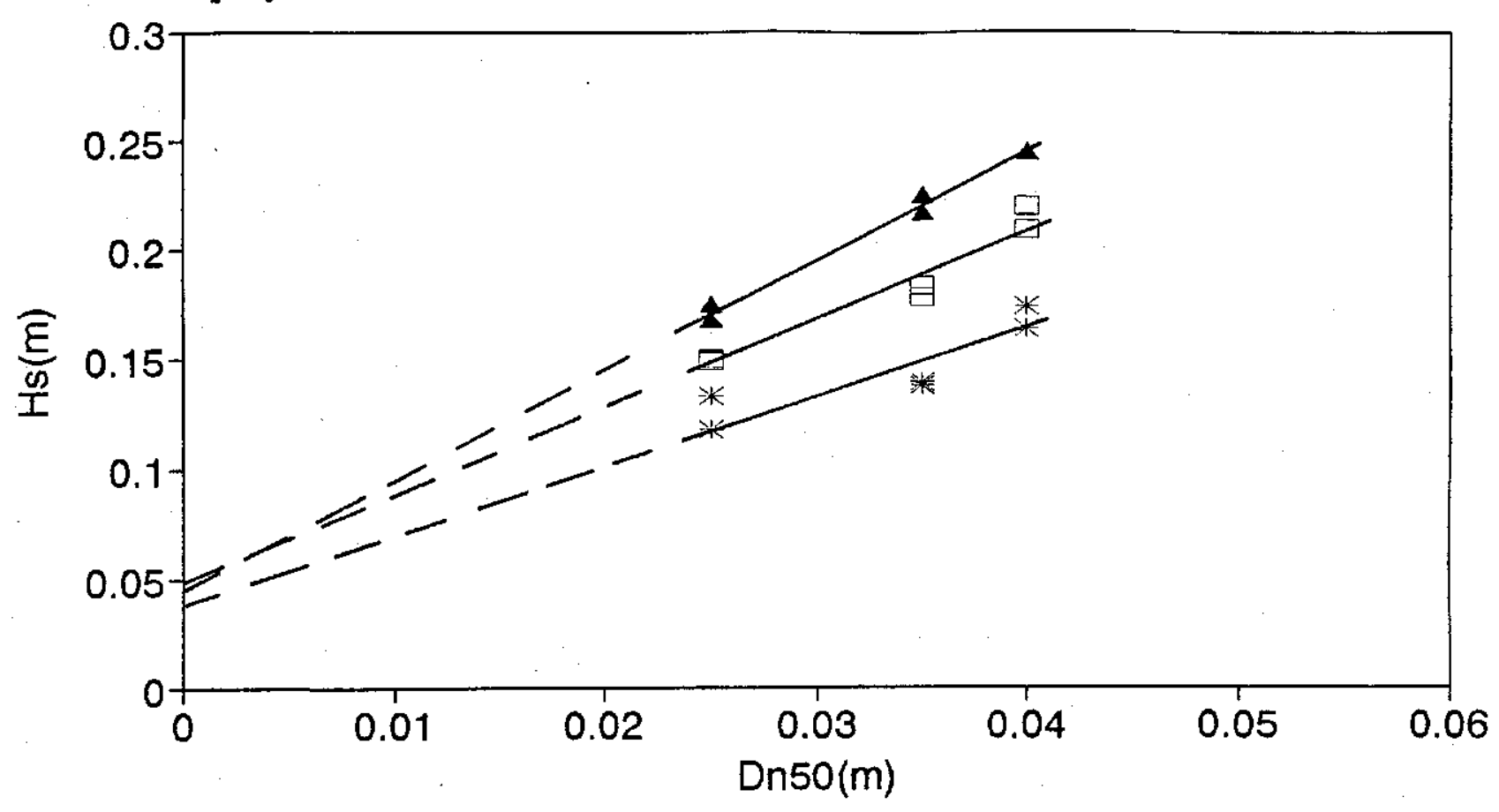

$$
\text { * Nod=0.5 } \square \quad \mathrm{Nod}=2 \quad \Delta \quad \mathrm{Nod}=4
$$

$h=0.9 m h_{-}-h_{t}=0.22 \mathrm{~m}$

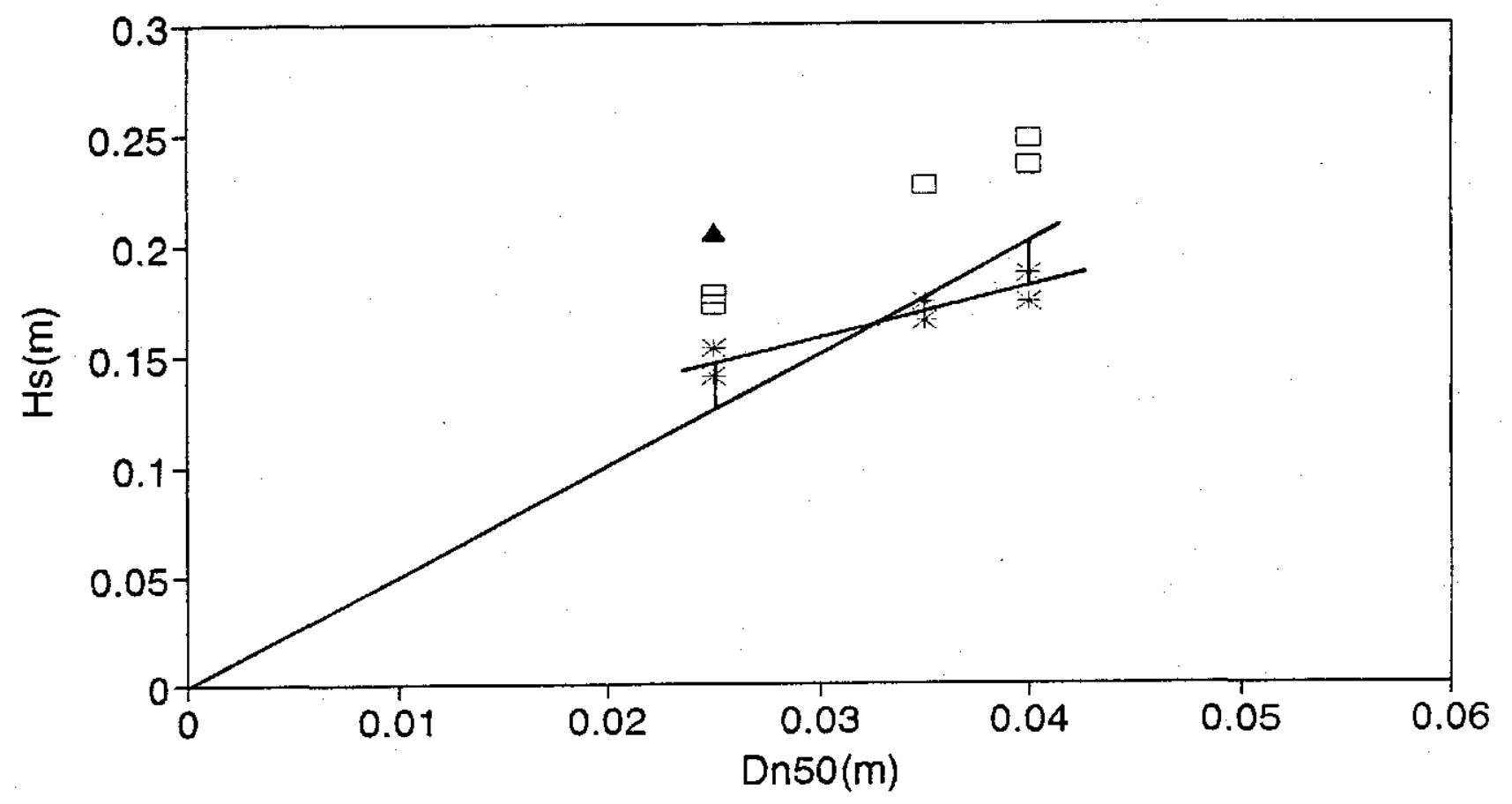

* Nod=0.5 $\square$ Nod $=2 \quad \Delta \quad \mathrm{Nod}=4$ 
damage level $\mathrm{N}_{\mathrm{od}}$ as a function of significant wave height $\mathrm{H}_{\mathrm{s}}$ for fixed stone diameters $D_{\text {nso }}$

$h=0.7 m h_{s}=0.3 m h_{a}-h_{t}=0.08 m$

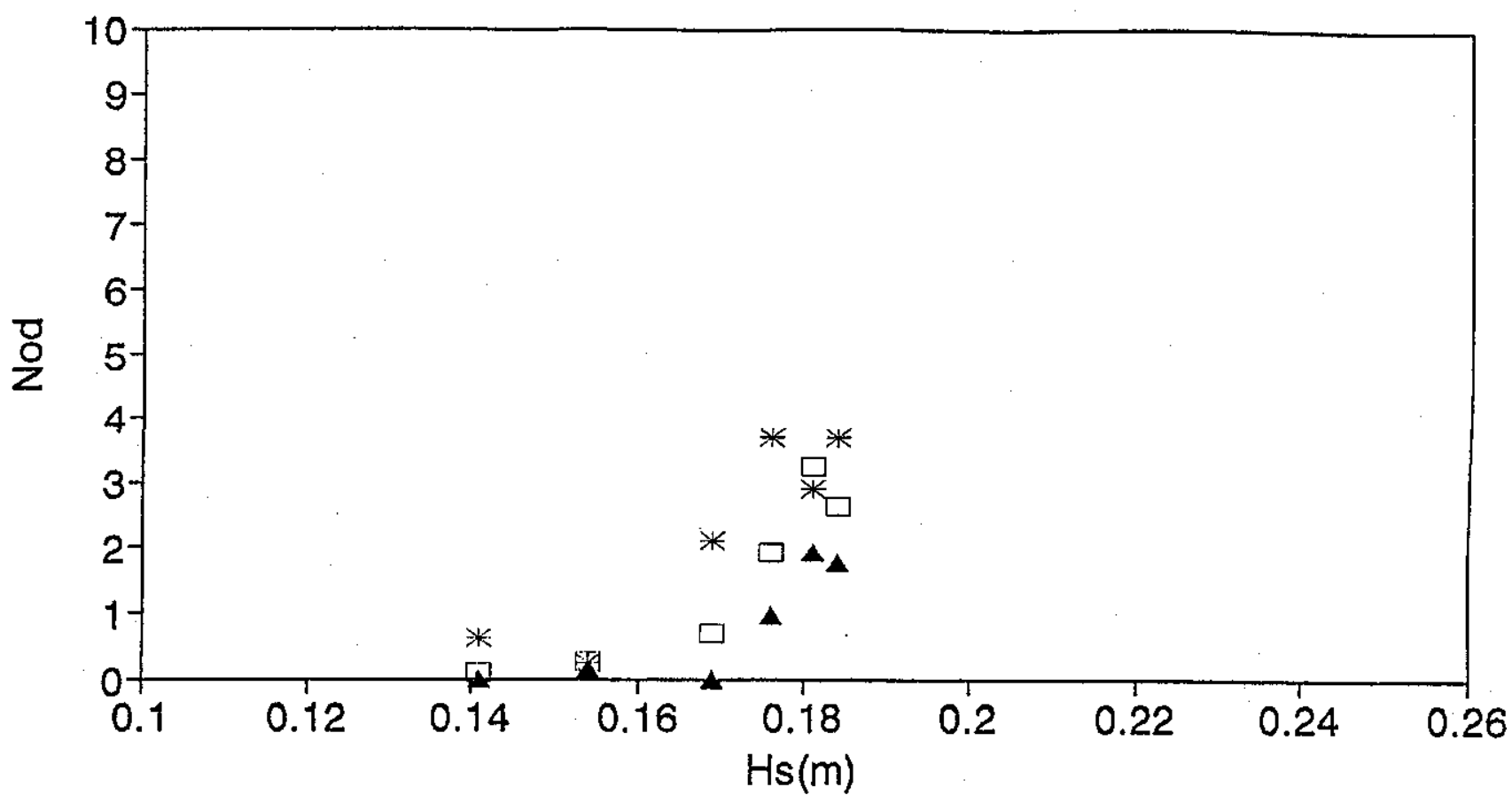

* $D_{n 50}=0.017 \mathrm{~m} \quad \square \quad D_{n 50}=0.025 \mathrm{~m} \quad \Delta \quad D_{150}=0.035 \mathrm{~m}$

$h=0.7 m h_{a}=0.3 m h_{n}-h_{t}=0.15 m$

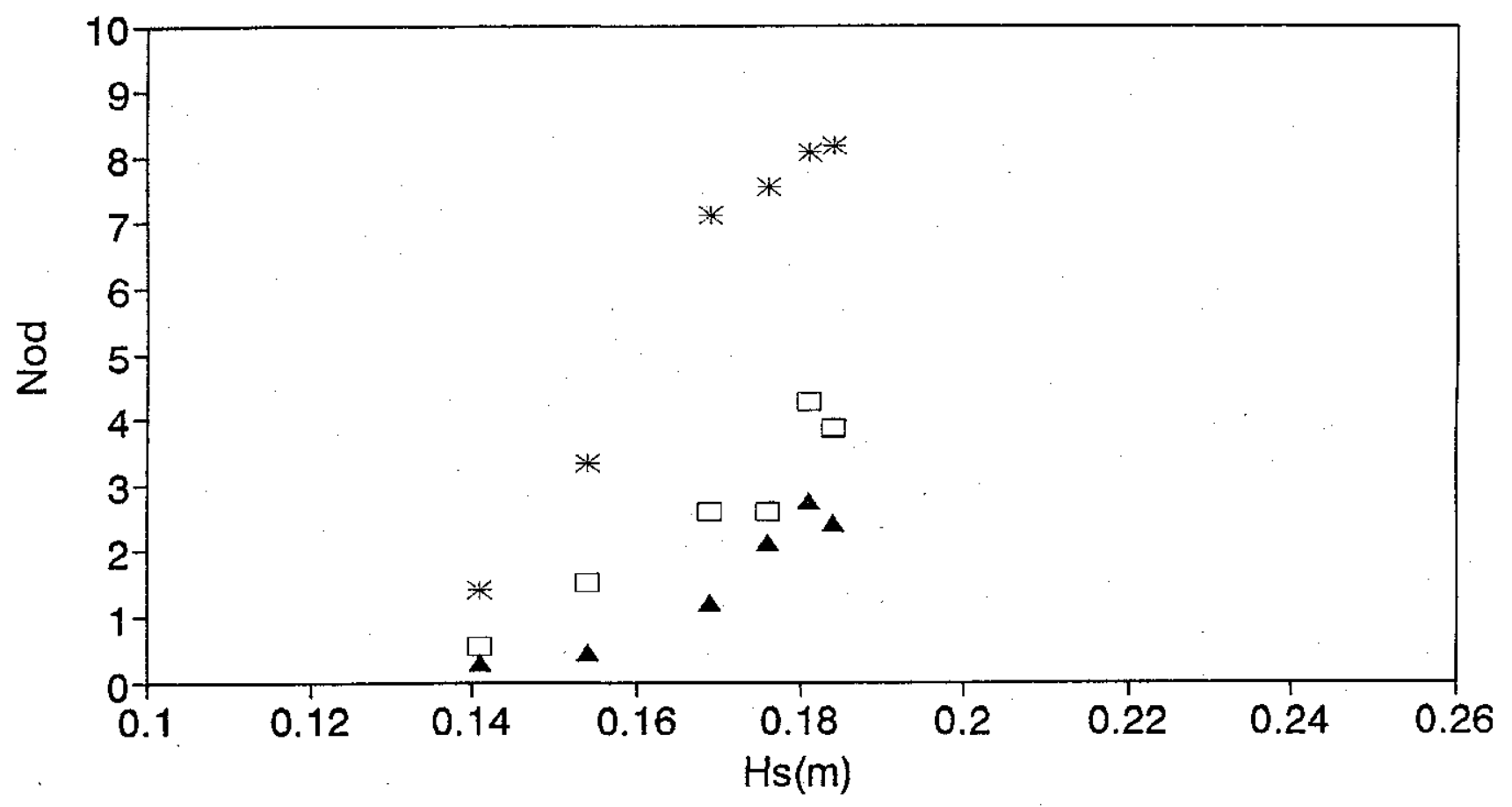

* $\quad D_{550}=0.025 \mathrm{~m} \quad \square \quad D_{a 50}=0.035 \mathrm{~m} \quad \sim D_{250}=0.040 \mathrm{~m}$ 
damage level $\mathrm{N}_{o d}$ as a function of significant wave height $\mathrm{H}_{\mathrm{s}}$ for fixed stone diameters $D_{n 50}$

$h=0.8 m h_{a}=0.4 m h_{a}-h_{t}=0.08 m$

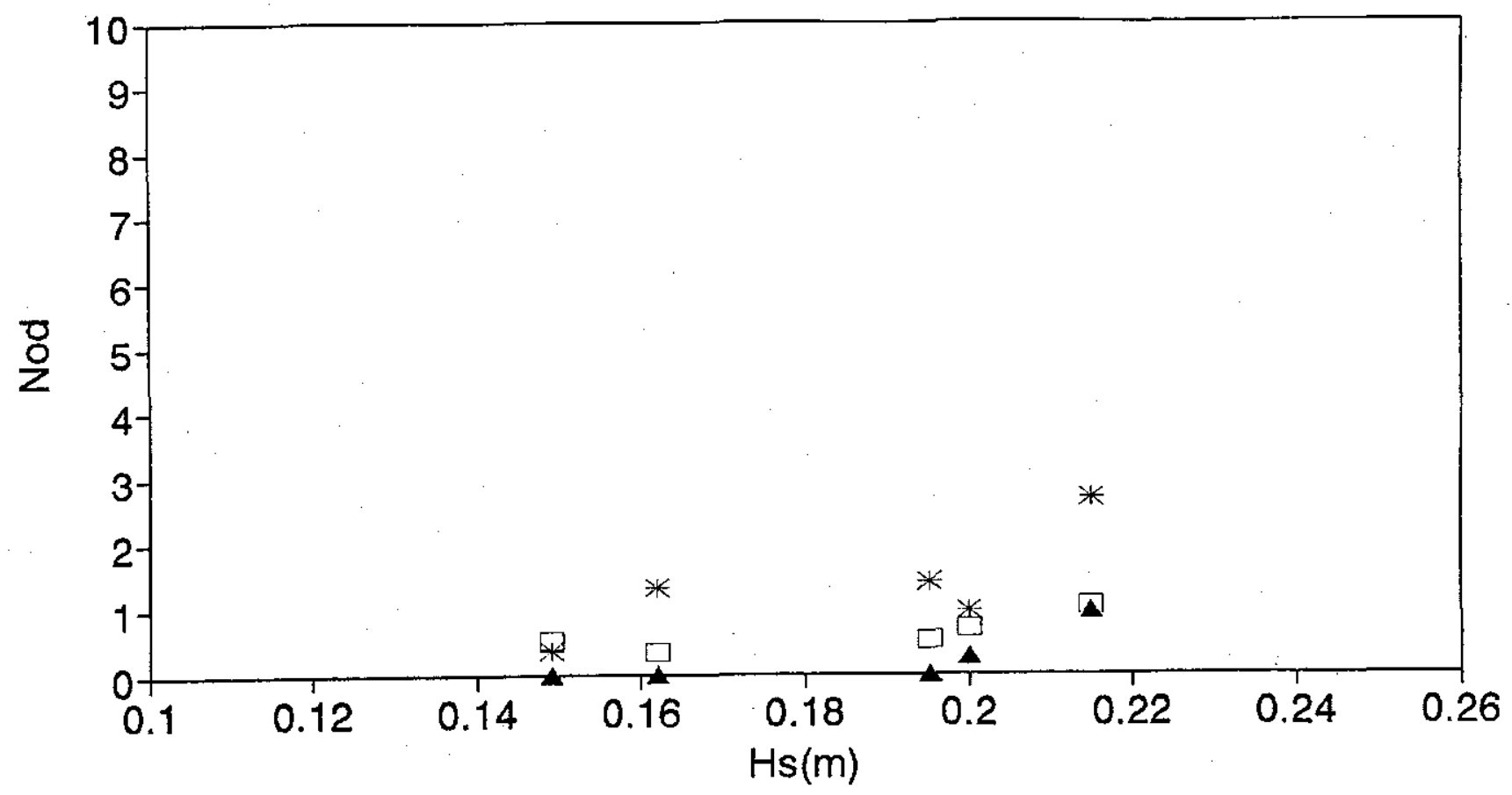

* $\quad D_{\mathrm{a} 50}=0.017 \mathrm{~m} \quad \square \quad D_{\mathrm{n} 50}=0.025 \mathrm{~m} \quad \triangle D_{\mathrm{n} 50}=0.035 \mathrm{~m}$

$h=0.9 m h_{1}=0.5 m h_{n}-h_{t}=0.08 m$

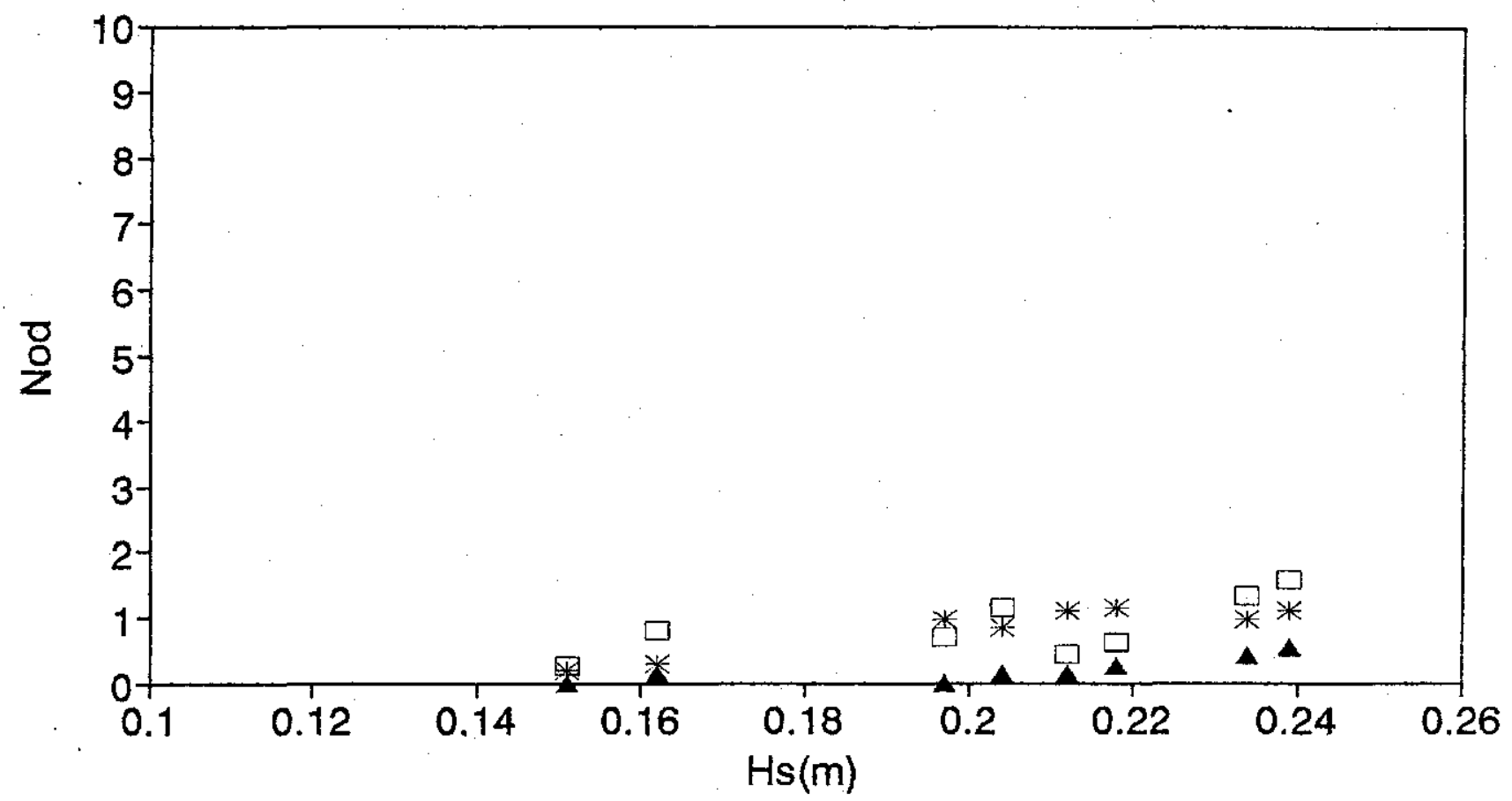

* $D_{n 50}=0.017 \mathrm{~m} \quad \square \quad D_{n 50}=0.025 \mathrm{~m} \quad \Delta \quad D_{150}=0.035 \mathrm{~m}$ 
damage level $N_{\text {od }}$ as a function of significant wave height $\mathrm{H}_{\mathrm{s}}$ for fiyed stone diameters $D_{n 50}$

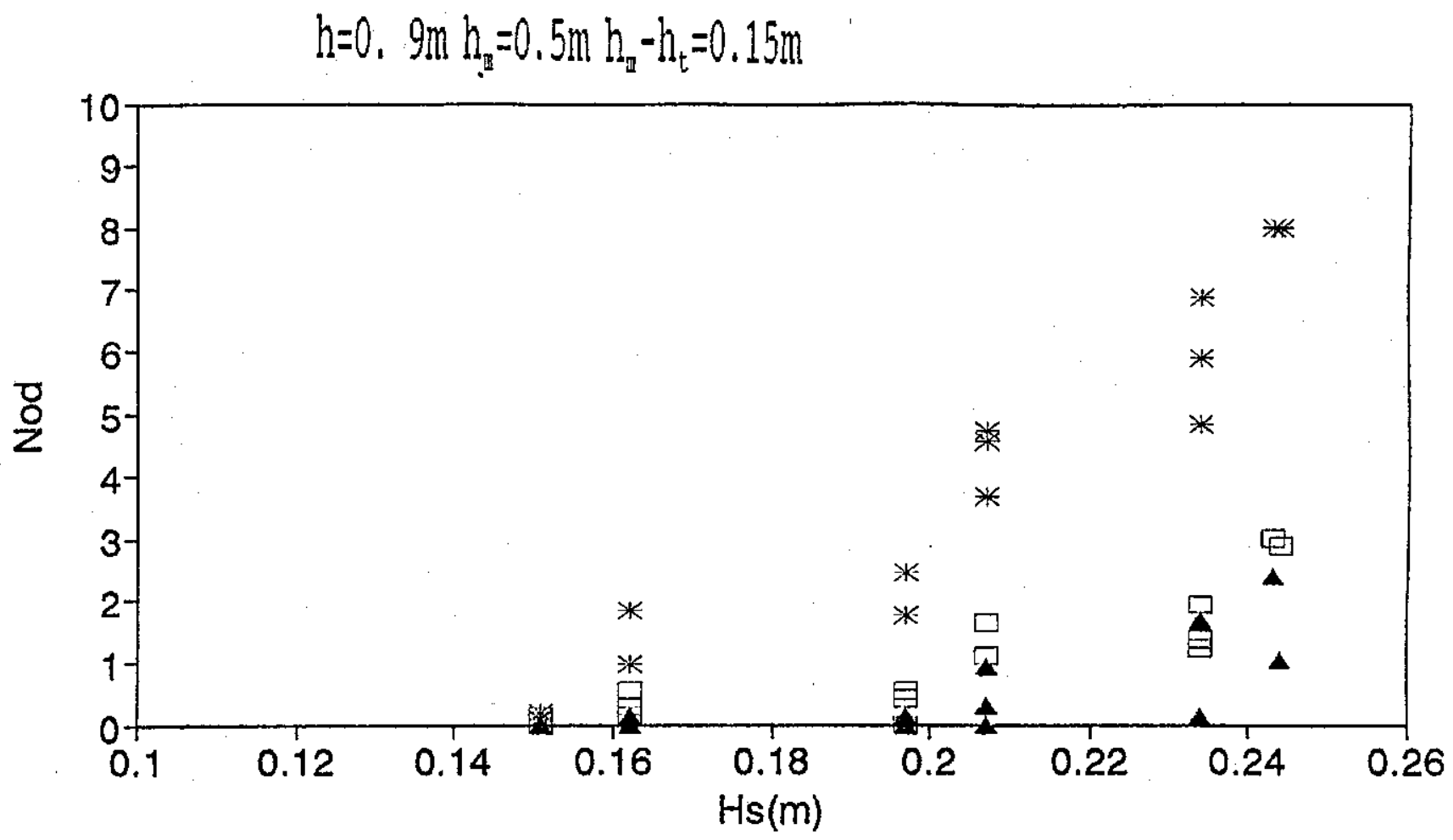

* $D_{\mathrm{n} 50}=0.025 \mathrm{~m} \quad \square \quad D_{\mathrm{n} 50}=0.035 \mathrm{~m} \quad \mathrm{D}_{\mathrm{n} 50}=0.040 \mathrm{~m}$

$h=0.9 m h_{2}=0.5 m h_{n}-h_{t}=0.22 m$

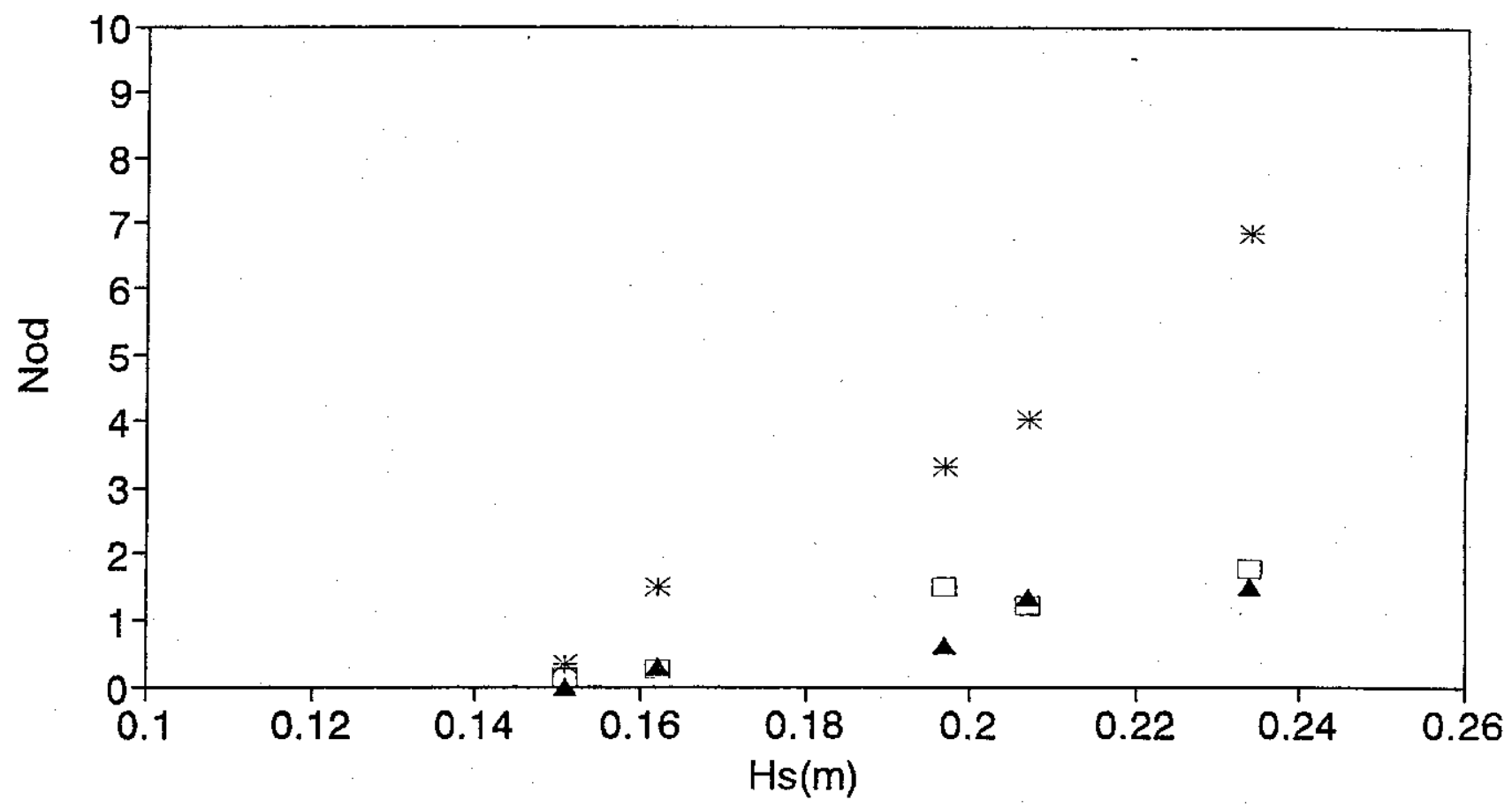

* $D_{\mathrm{n} 50}=0.025 \mathrm{~m} \quad \square \quad D_{\mathrm{n} 50}=0.035 \mathrm{~m} \quad \Delta \quad \mathrm{D}_{\mathrm{n} 50}=0.040 \mathrm{~m}$ 
damage level $\mathrm{N}_{\mathrm{od}}$ as a function of significant wave height $\mathrm{H}_{\mathrm{s}}$ for fixed stone diameters $D_{550}$

$h=0.8 m h_{s}=0.4 m h_{1}-h_{t}=0.22 m$

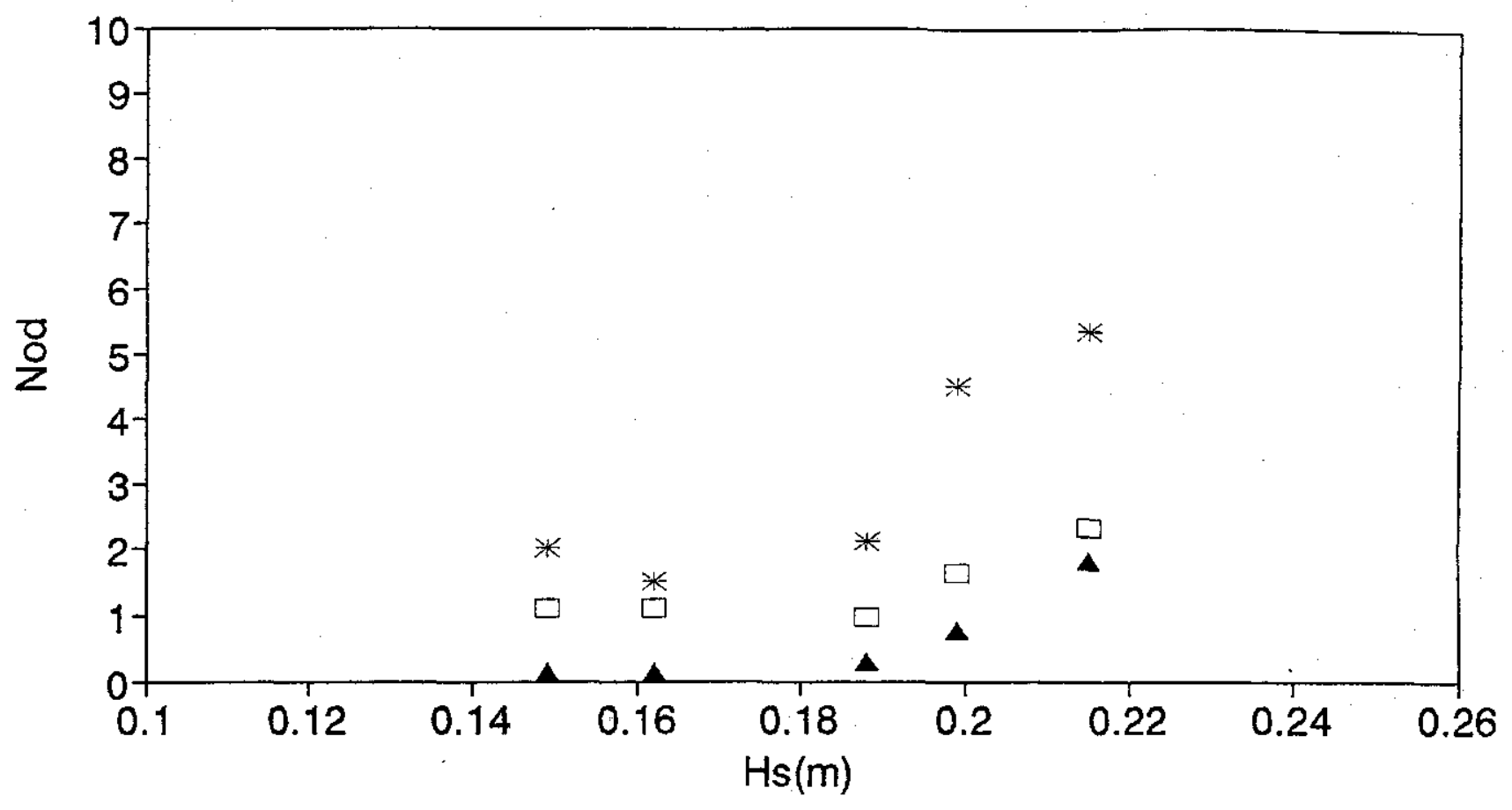

* $\quad D_{\mathrm{n} 50}=0.025 \mathrm{~m} \square \quad D_{\mathrm{n} 50}=0.035 \mathrm{~m} \quad \triangle \mathrm{D}_{550}=0.040 \mathrm{~m}$

$h=0.8 m h_{a}=0.4 m h_{n}-h_{t}=0.15 m$

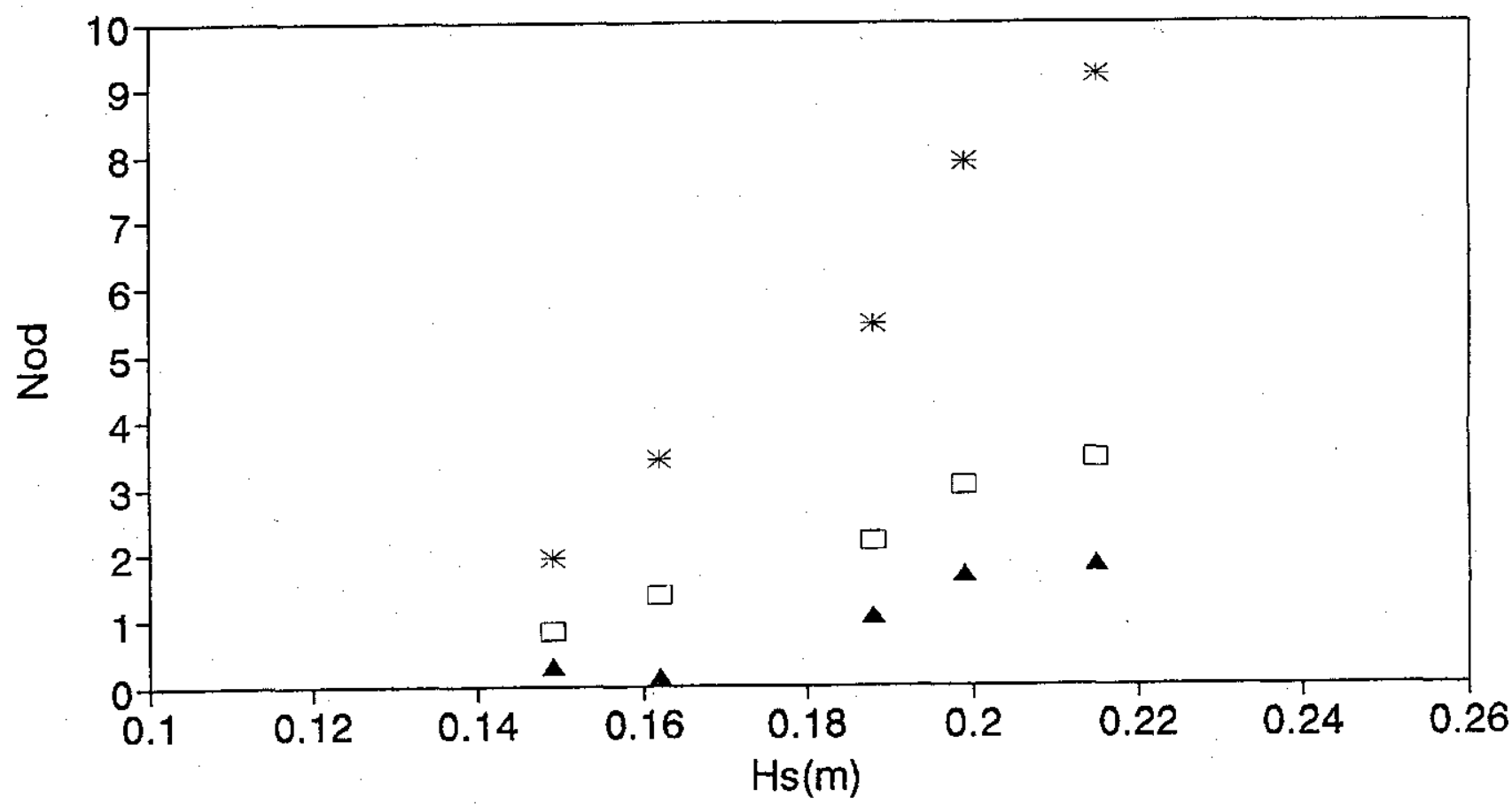

* $\quad D_{\mathrm{n} 50}=0.025 \mathrm{~m} \square D_{\mathrm{n} 50}=0.035 \mathrm{~m} \quad \triangle \mathrm{D}_{\mathrm{ns} 0}=0.040 \mathrm{~m}$ 


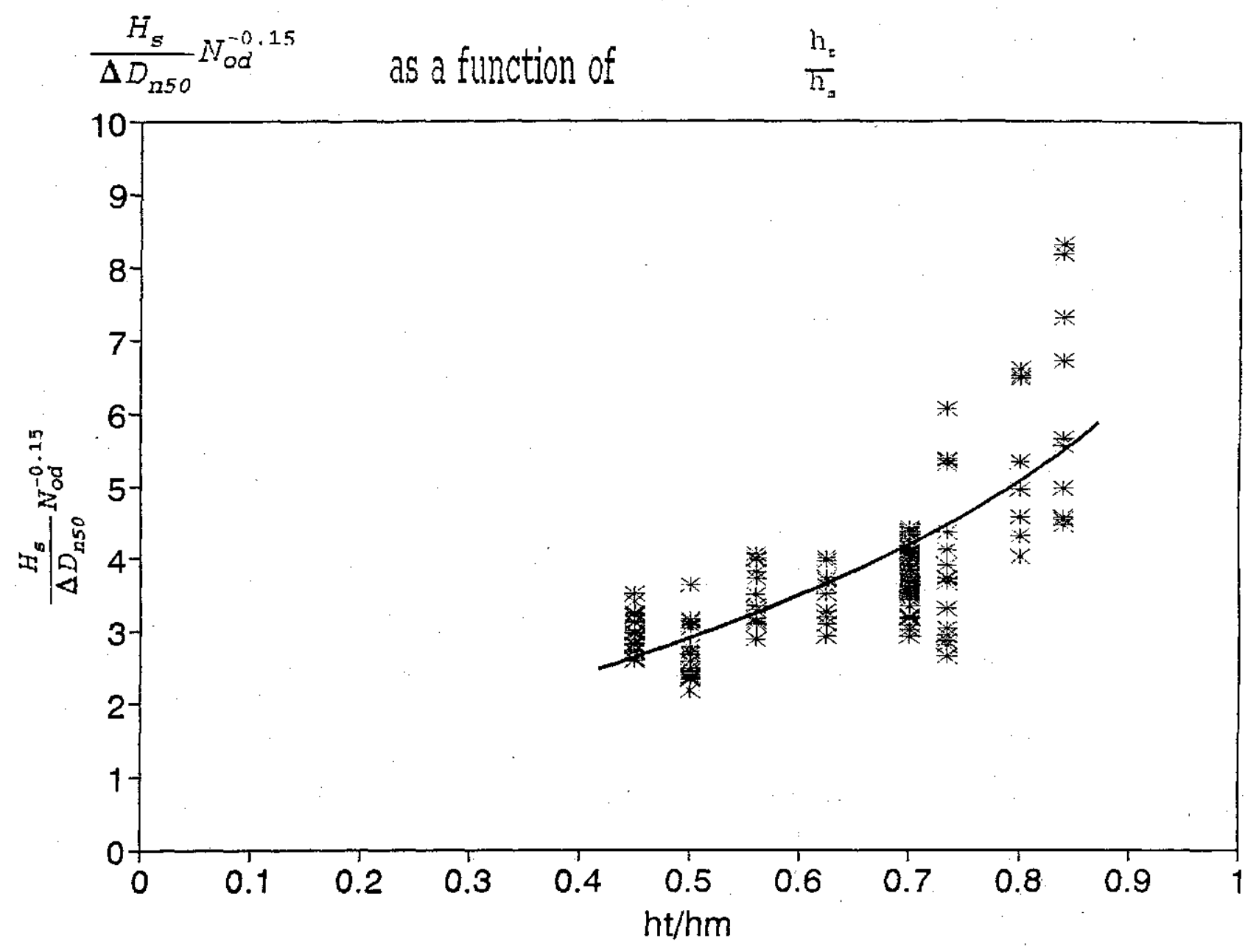




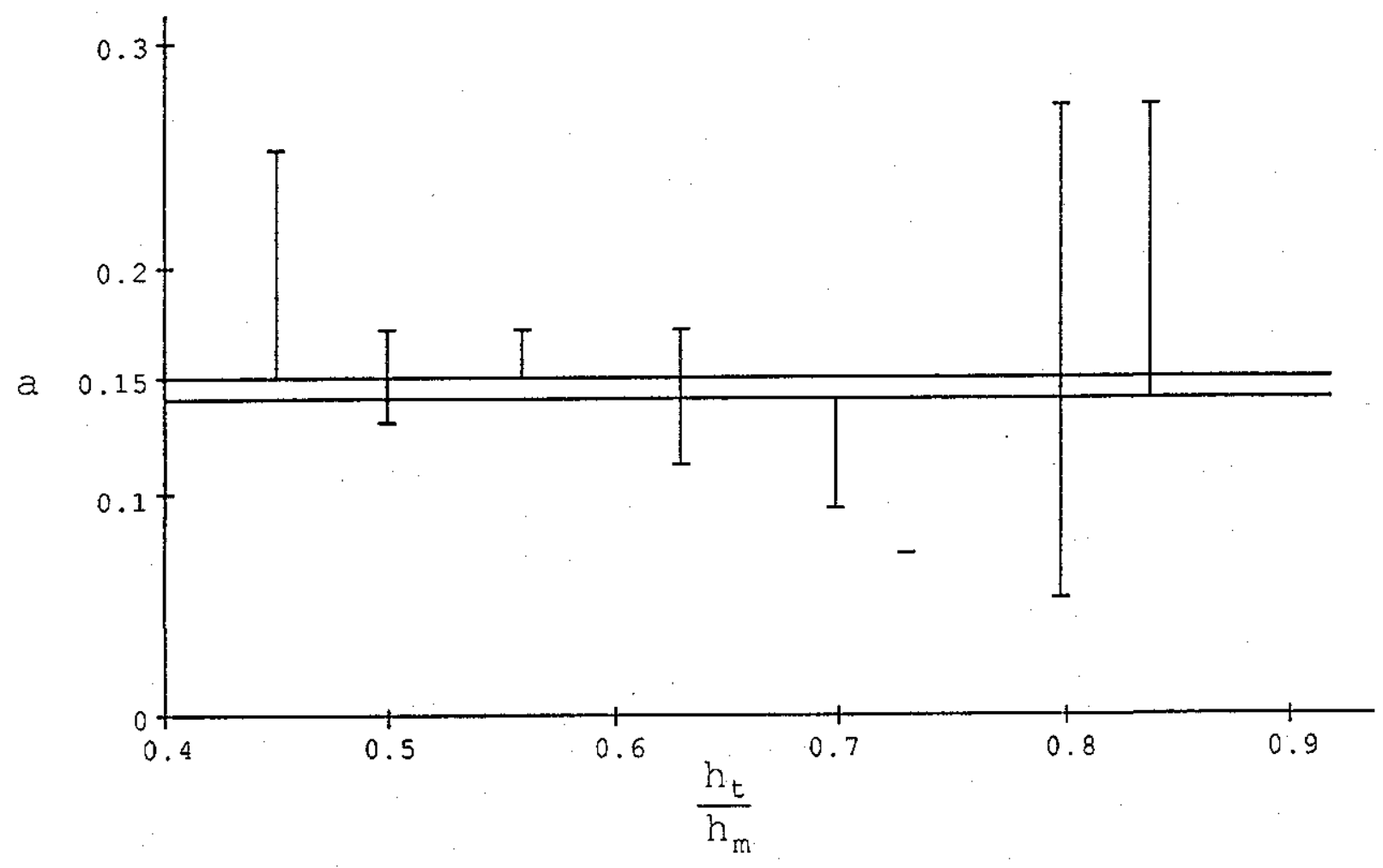

Eigure 42: Values of a for $\frac{h_{t}}{h_{m}}$ in $H_{s}=$ function $* N_{\text {od }}^{a}$ 
$\frac{H_{s}}{\Delta D_{n 50}} N_{o d}^{-0.15}$

as a function of $\quad \frac{h_{t}}{h_{m}}$

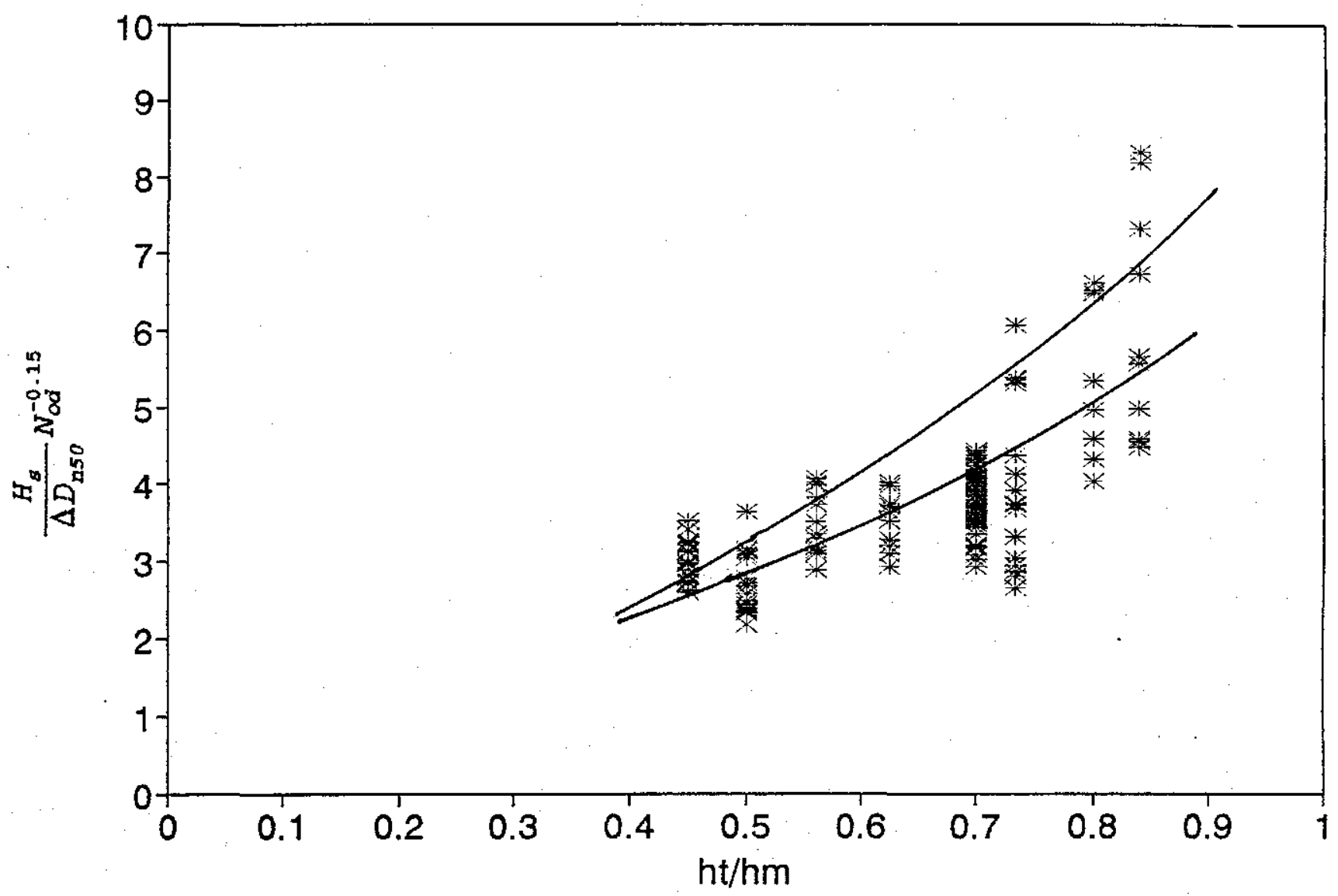


$\frac{H_{s}}{\Delta D_{n 50}} N_{o d}^{-0.25}$

as a function of

$h=0.7 \mathrm{~m}$

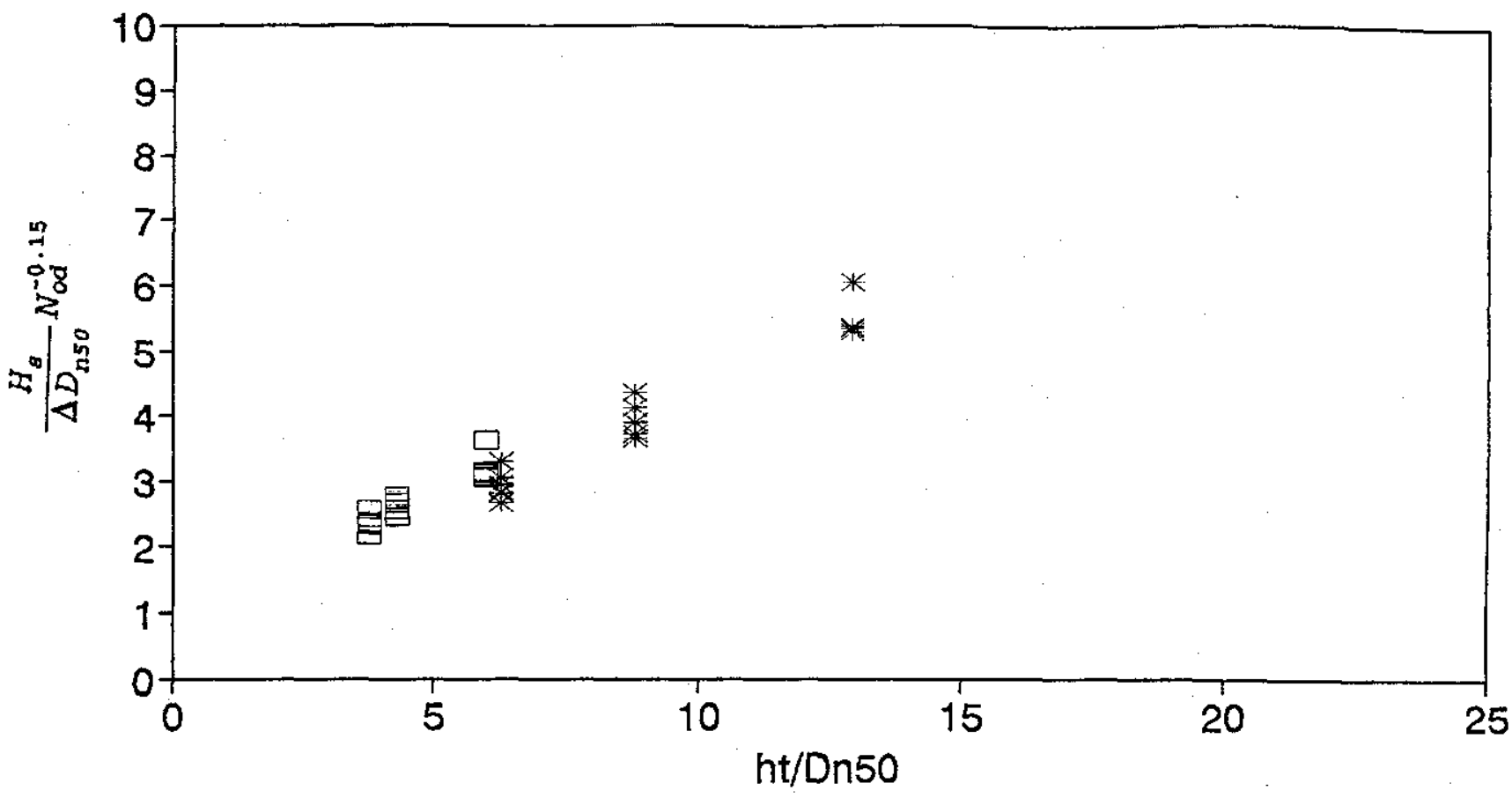

* $\mathrm{hm}-\mathrm{ht}=0.08 \mathrm{~m} \quad \square \mathrm{hm}-\mathrm{ht}=0.15 \mathrm{~m}$

$\frac{H_{s}}{\Delta D_{n 50}} N_{o d}^{-0.15}$. as a function of $\quad \frac{h_{t}}{H_{s}}$ for fixed toe heights

$\mathrm{h}=0.7 \mathrm{~m}$

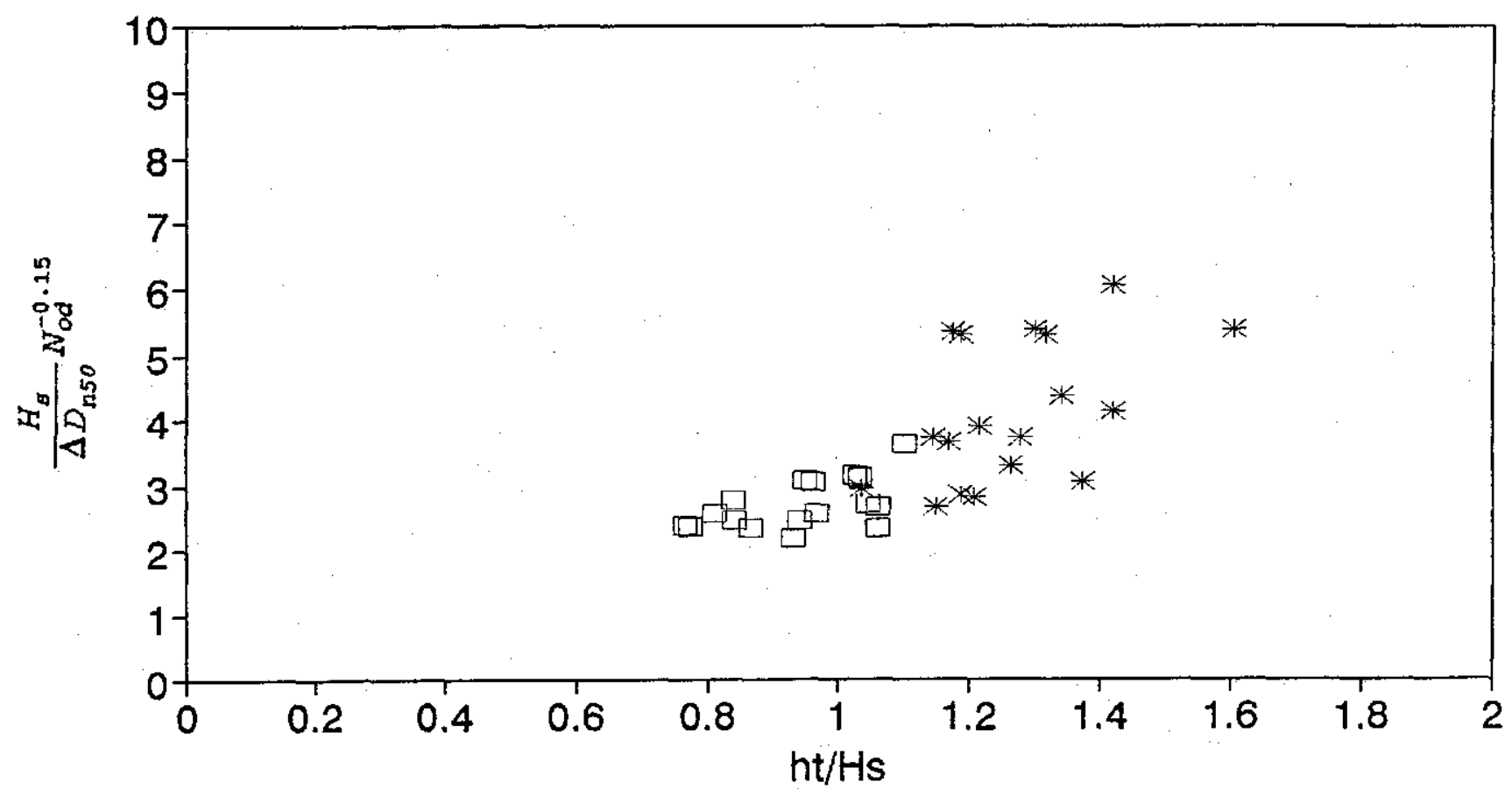

* $\mathrm{hm}-\mathrm{ht}=0.08 \mathrm{~m} \quad \square . \mathrm{hm}-\mathrm{ht}=0.15 \mathrm{~m}$ 

$\frac{H_{s}}{\Delta D_{n 50}} N_{o d}^{-0.15}$
as a function of
$\frac{h_{t}}{D_{n 50}}$

for fixed toe heights $h=0.8 \mathrm{~m}$

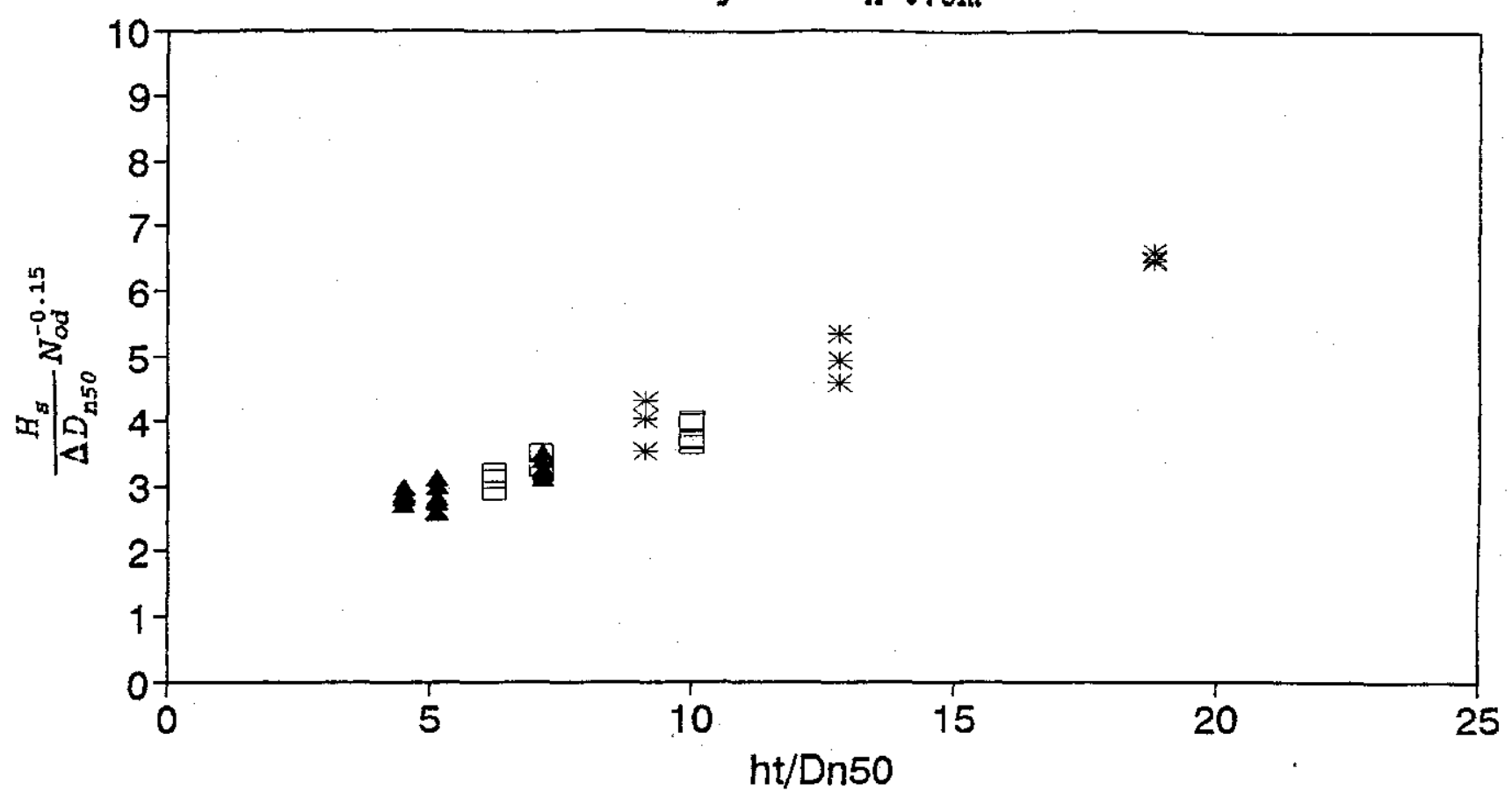

* $\mathrm{hm}-\mathrm{ht}=0.08 \mathrm{~m} \square \mathrm{hm}-\mathrm{ht}=0.15 \mathrm{~m} \Delta \mathrm{hm}-\mathrm{ht}=0.22 \mathrm{~m}$

$\frac{H_{s}}{\Delta D_{n 50}} N_{o d}^{-0.15} \quad$ as a function of $\quad \frac{h_{t}}{H_{s}}$

for fixed toe heights $h=0.8 \mathrm{~m}$

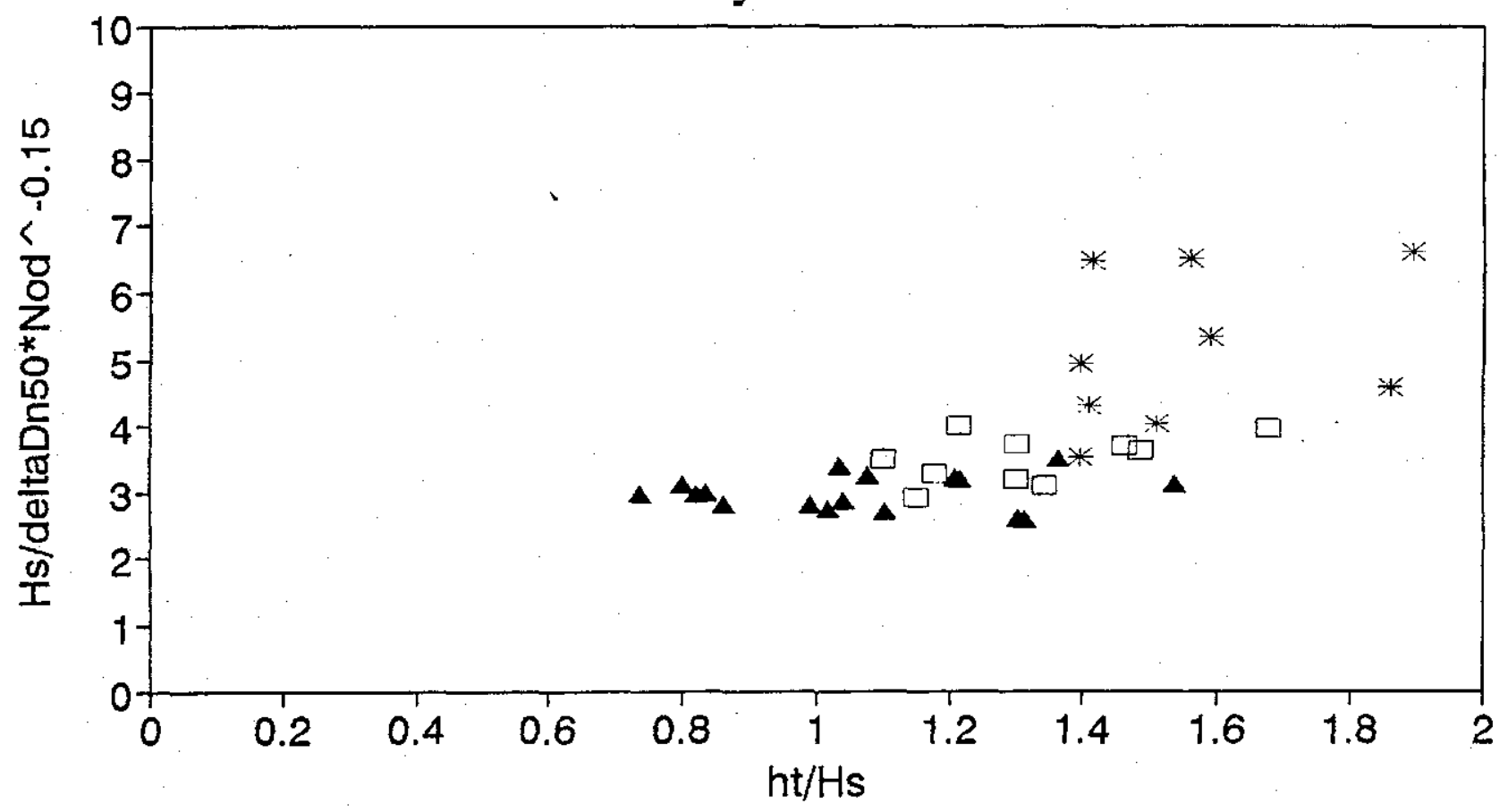

* hm-ht $=0.08 \mathrm{~m} \square \mathrm{hm}-\mathrm{ht}=0.15 \mathrm{~m} \Delta \mathrm{hm}-\mathrm{ht}=0.22 \mathrm{~m}$ 
$\frac{H_{s}}{\Delta D_{n 50}} N_{o d}^{-0.15}$ as a function of $\frac{h_{t}}{D_{n 50}} \quad$ for fixed toe heiglits

$h=0.9 \mathrm{~m}$

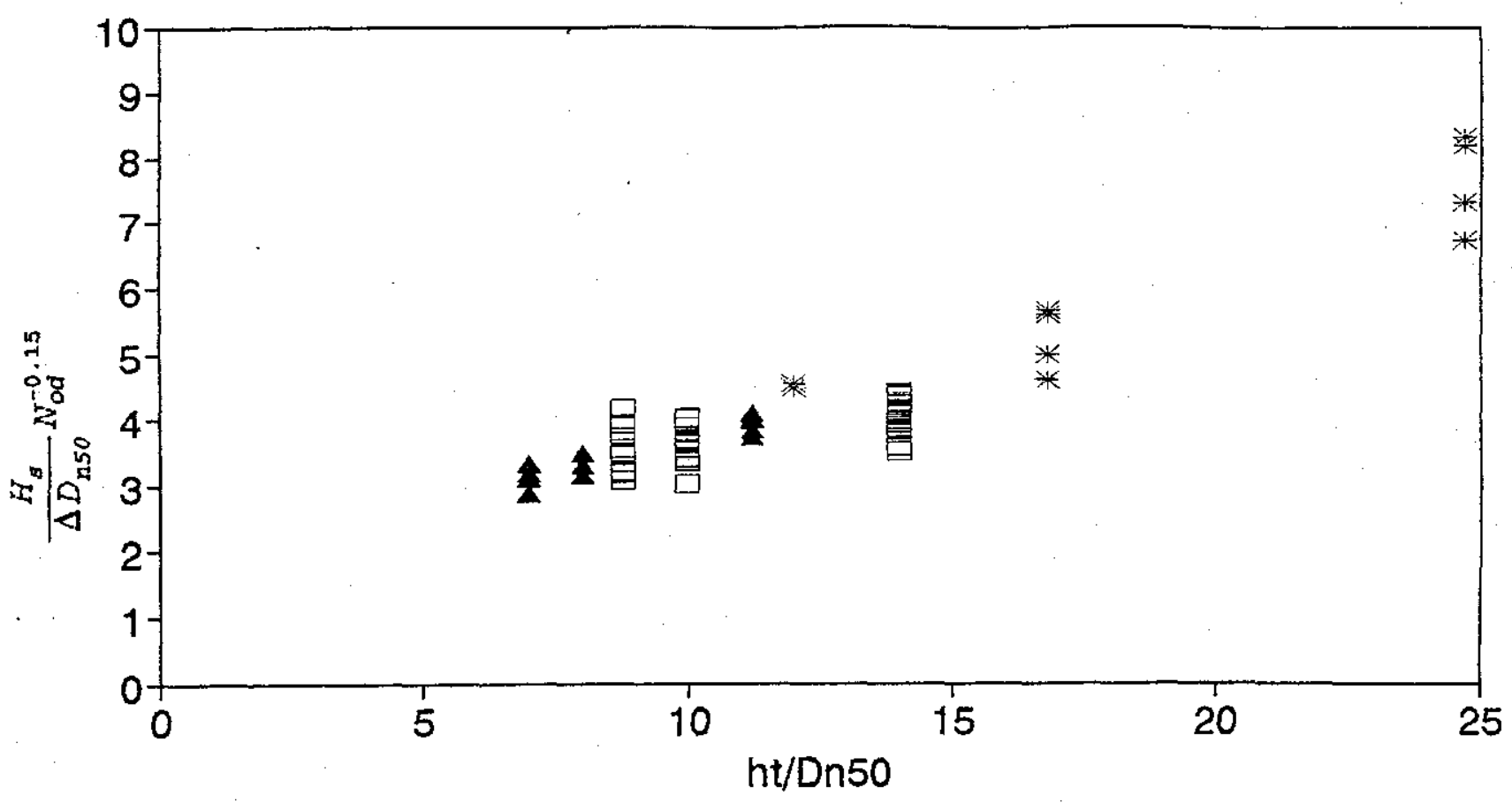

* $\mathrm{hm}-\mathrm{ht}=0.08 \mathrm{~m} \square \mathrm{hm}-\mathrm{ht}=0.15 \mathrm{~m} \Delta \mathrm{hm}-\mathrm{ht}=0.22 \mathrm{~m}$

$\frac{H_{s}}{\Delta D_{n 50}} N_{o d}^{-0.15}$ as a function of $\frac{h_{t}}{H_{s}} \quad$ for fixed toe heights

$h=0.9 \mathrm{~m}$

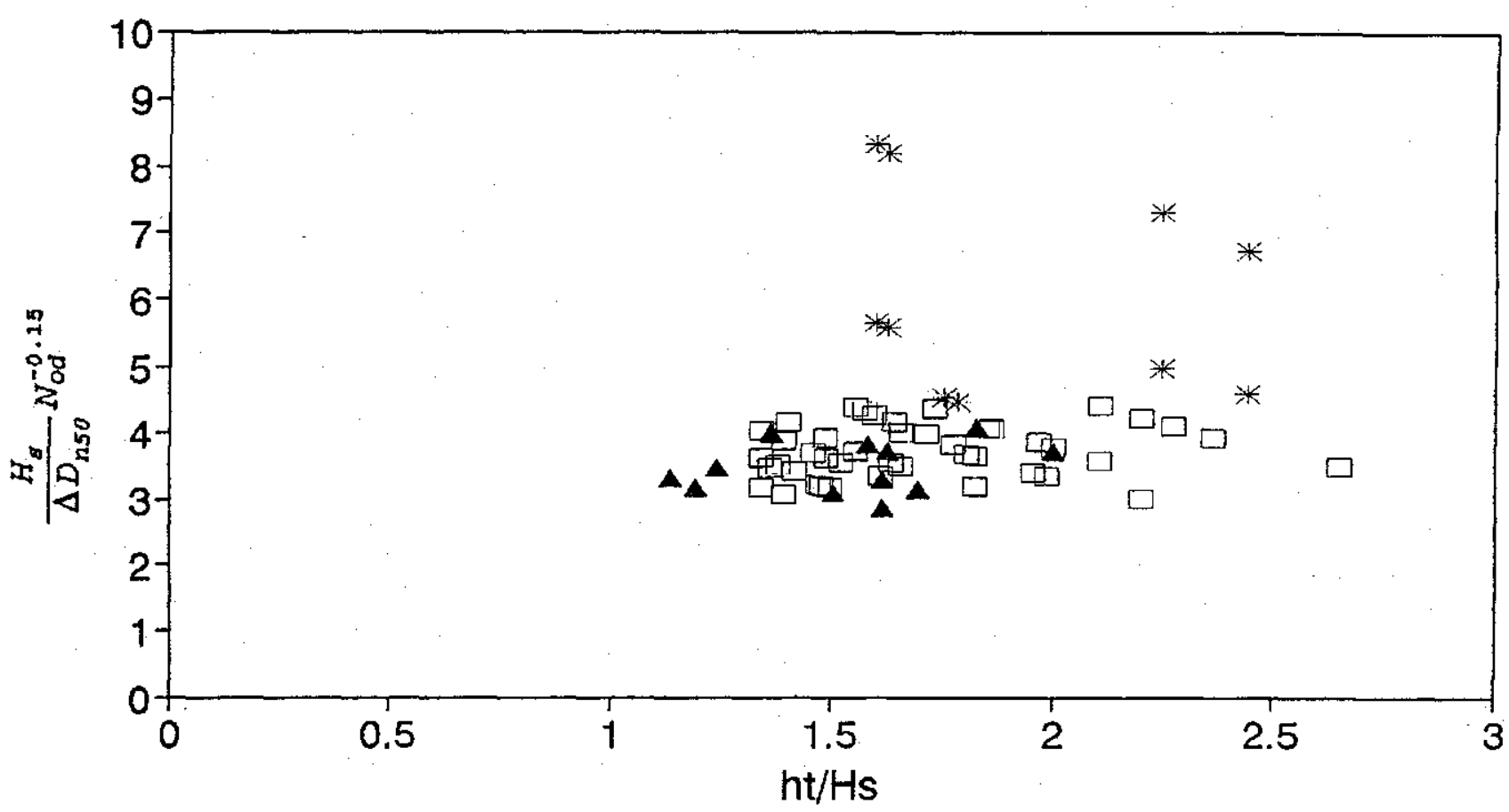

* $\mathrm{hm}-\mathrm{ht}=0.08 \mathrm{~m} \quad \square \mathrm{hm}-\mathrm{ht}=0.15 \mathrm{~m} \Delta \mathrm{hm}-\mathrm{ht}=0.22 \mathrm{~m}$ 
$\frac{H_{s}}{\Delta \bar{D}_{n .50}} N_{o d}^{-0.15} \quad$ as a function of $\quad \frac{h_{t}}{D_{n .50}}$

smoothed dataset with fixed damage levels

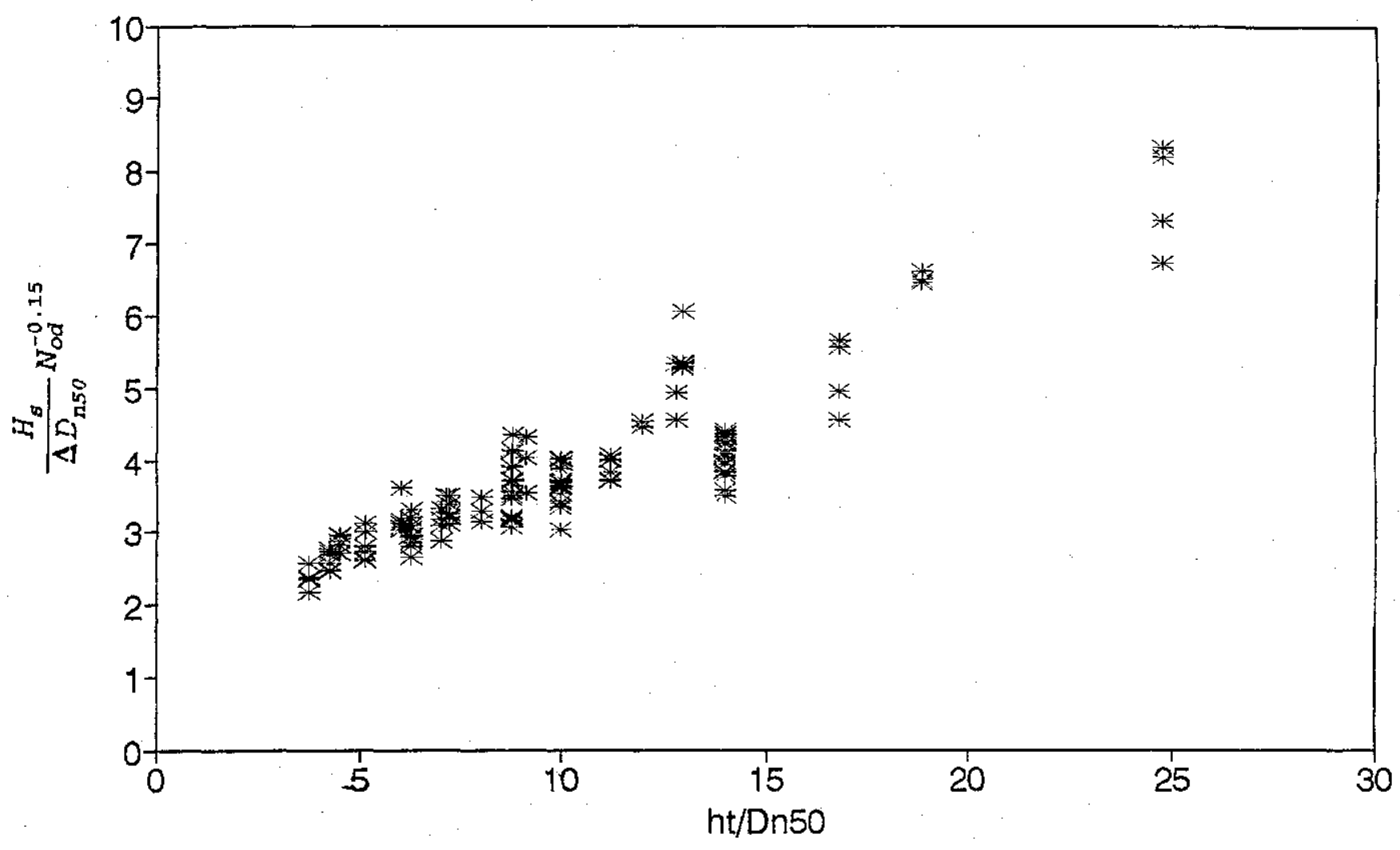




$$
\left(\frac{H_{s}}{\Delta \bar{D}_{n .50}} N_{o d}^{-0.15}-1.6\right) * 4.2 \frac{D_{n s 0}}{h_{t}} \text { aS a function of } \frac{h_{m}}{\ddot{H}_{s}}
$$

\section{smoothed dataset}

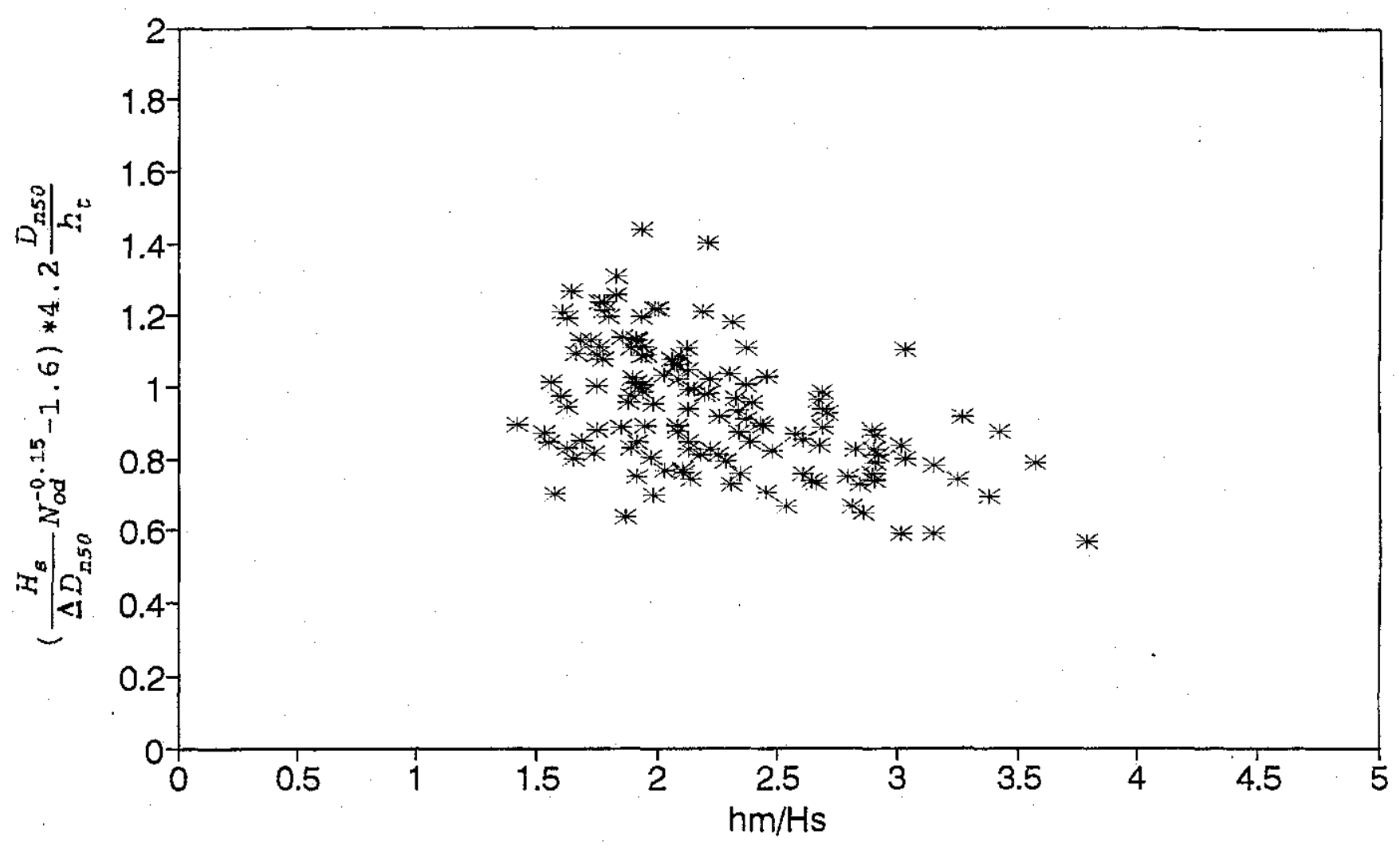


$\frac{H_{s}}{\Delta \bar{D}_{n .50}} N_{o d}^{-0.15}$ as a function of $\frac{h_{t}}{\bar{D}_{n .50}}$

original dataset

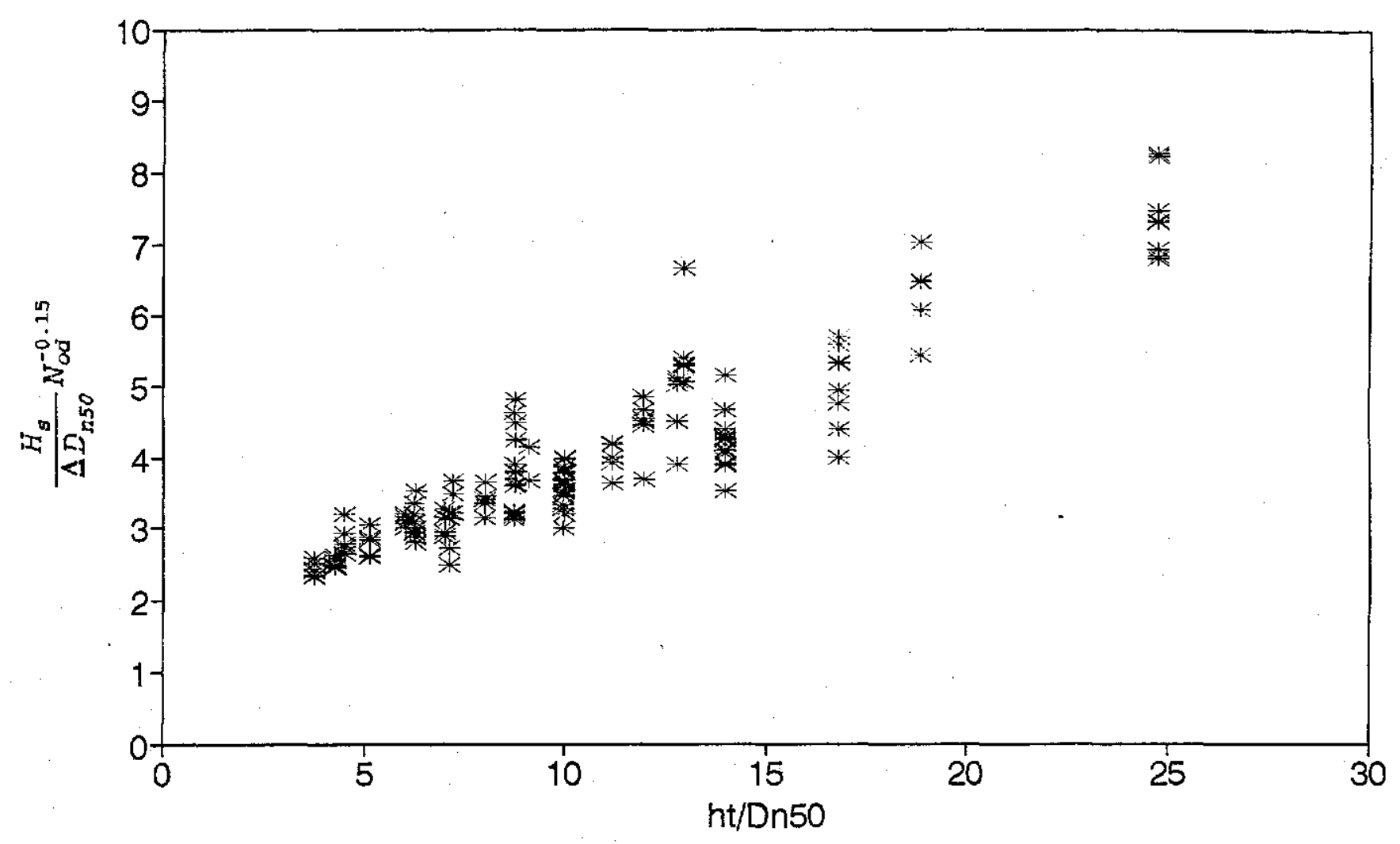


$\left(\frac{H_{s}}{\Delta \bar{D}_{n 50}} N_{o d}^{-0.15}-1.6\right) * 4.2 \frac{D_{n 50}}{h_{t}}$ aS a function of $\frac{h_{m}}{\ddot{H}_{s}}$ original dataset

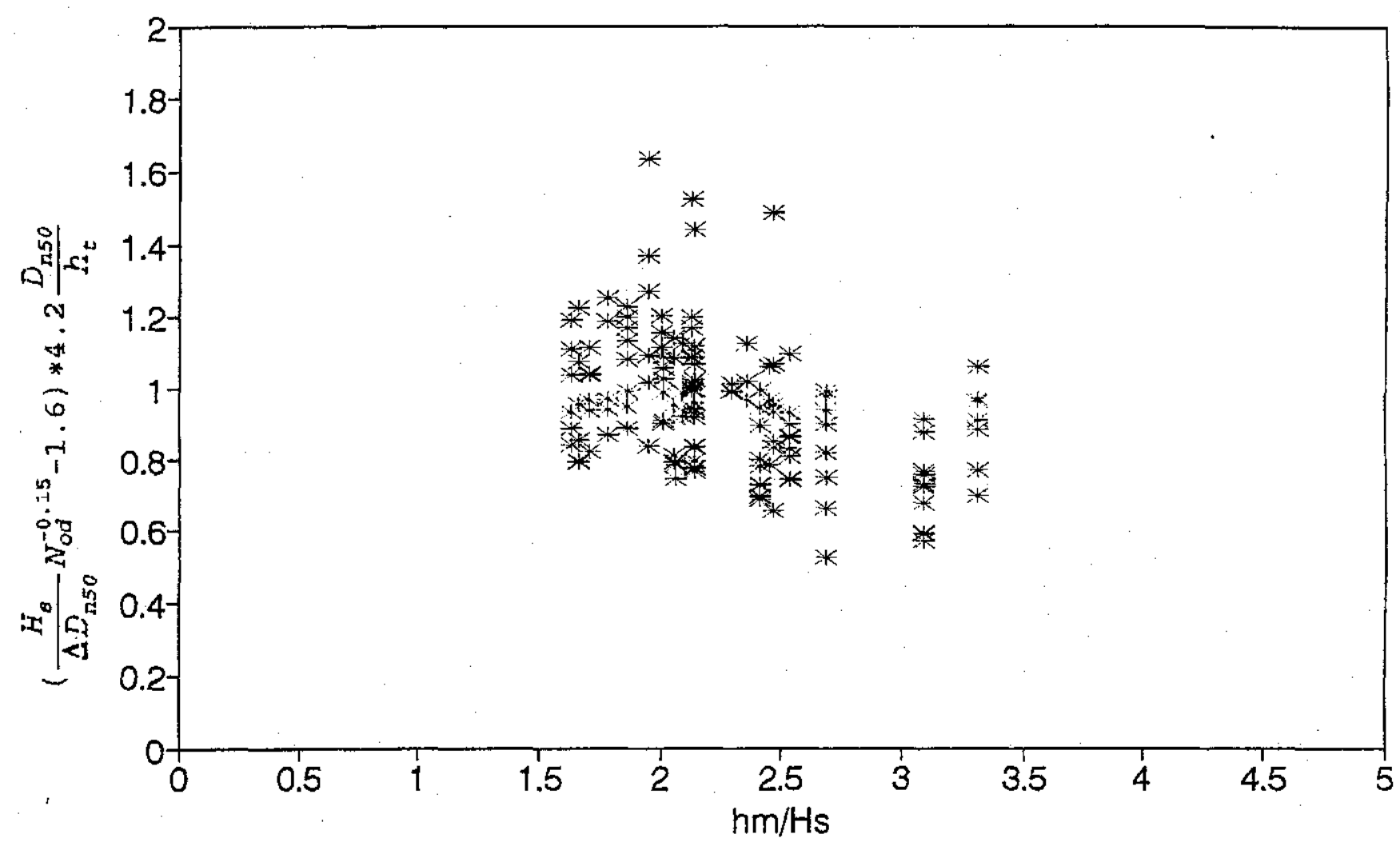




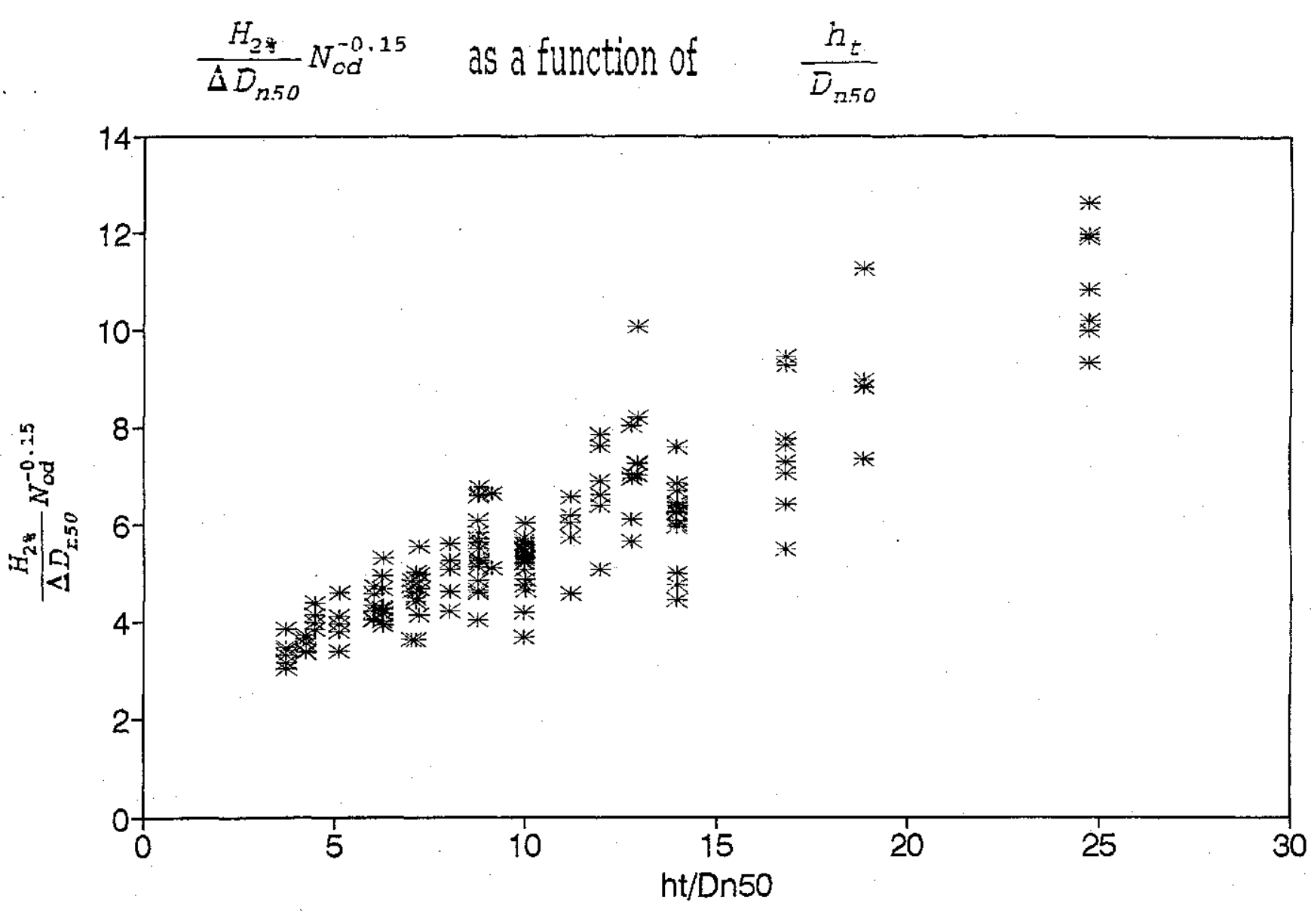

figure 52 


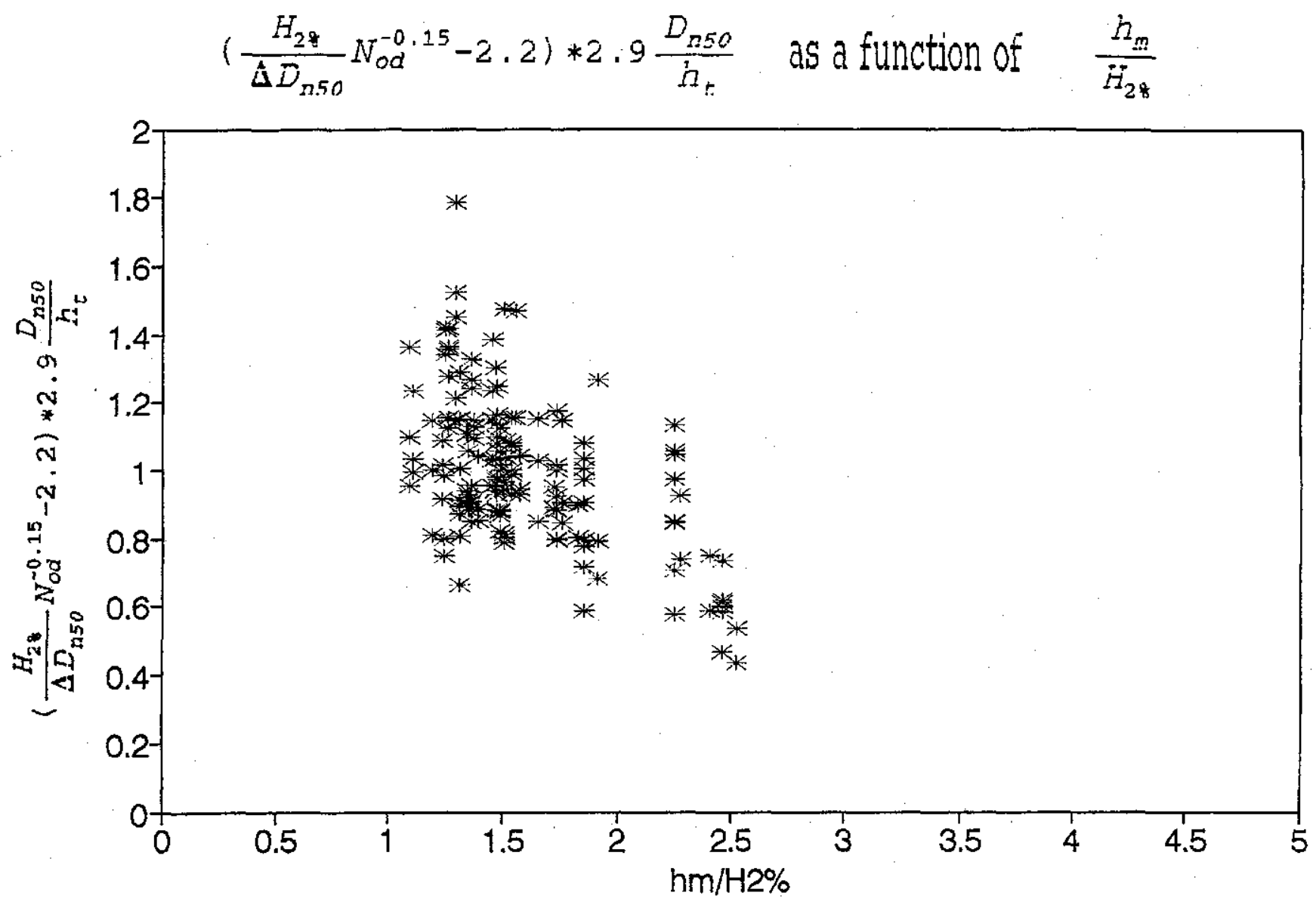


$\frac{H_{s}}{\Delta D_{n 50}} N_{o d}^{-0.15}$ as a function of $\frac{h_{t}}{D_{n 50}}$

existing testdata

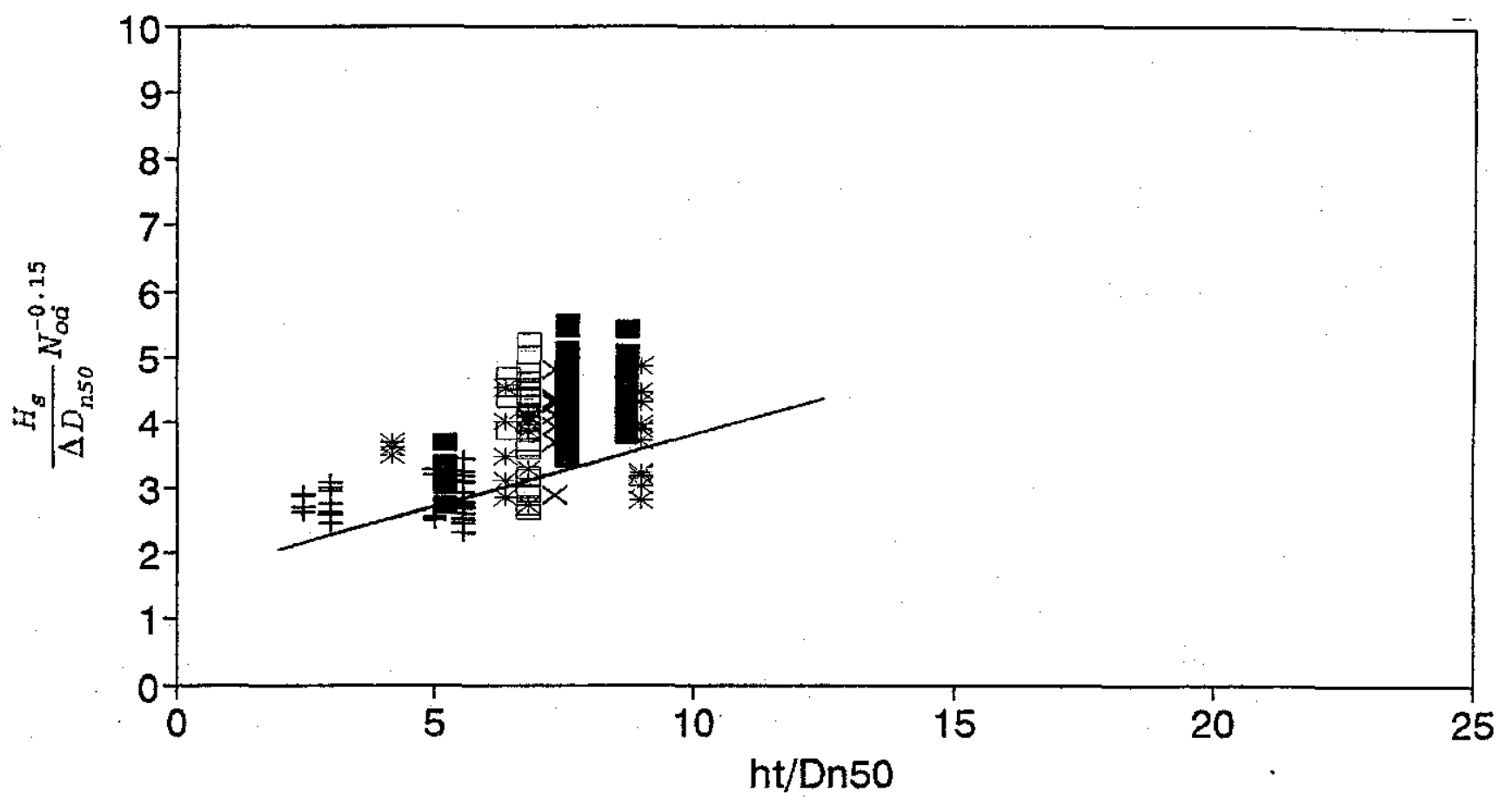

* testseries $1 \square$ testseries $2+$ testseries 3

- testseries $4 \times$ testseries 5 


$$
\frac{H_{s}}{\Delta D_{n 50}} N_{0 d}^{-0.15} \text { as a function of } \frac{h_{t}}{D_{n 50}}
$$

existing testdata $\quad N_{\partial d}>0.5$

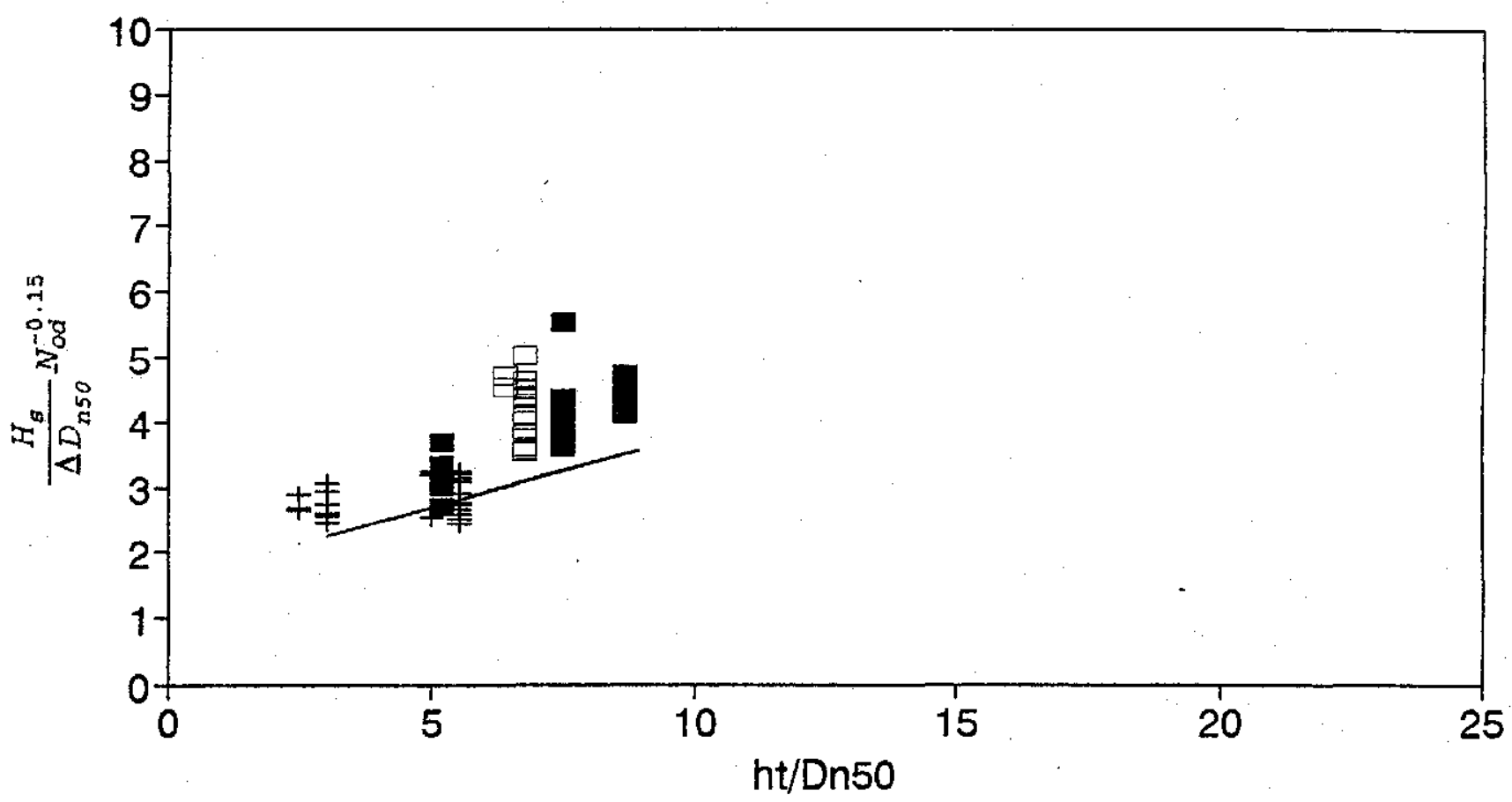

* testseries $1 \square$ testseries $2+$ testseries 3 a testseries 4 
stones used : $\quad D_{\mathrm{n} 50}=0.017 \mathrm{~m}, 0.025 \mathrm{~m}, 0.035 \mathrm{~m}, 0.040 \mathrm{~m}$, $\mathrm{D}_{85} / \mathrm{D}_{15}=1.15-1.30$.

rock density for all stones used : $\rho_{\mathrm{s}}=2680 \mathrm{~kg} / \mathrm{m}^{3}$

$$
\Delta=\rho_{\mathrm{s}}-\rho_{\mathrm{w}} / \rho_{\mathrm{w}}=1,68
$$

tests performed : toe height $0.08 \mathrm{~m}$, toe width $0.12 \mathrm{~m}$

number of stones used with $D_{n 50}: 0.017 \mathrm{~m}, 318 ; 0.025 \mathrm{~m}, 112 ; 0.035 \mathrm{~m}, 47$

water depth : near wave board $0.9 \mathrm{~m}$; at the structure $0.5 \mathrm{~m}$

wave steepness : $0.02 \quad$ wave heights : $0.15 \mathrm{~m}, 0.20 \mathrm{~m}, 0.25 \mathrm{~m}$

$0.03 \quad 0.20 \mathrm{~m}$

$0.04 \quad 0.15 \mathrm{~m}, 0.20 \mathrm{~m}, 0.25 \mathrm{~m}$

tests performed : toe height $0.08 \mathrm{~m}$, toe width $0.12 \mathrm{~m}$

number of stones used with $\mathrm{D}_{\mathrm{n} 50}: 0.017 \mathrm{~m}, 318 ; 0.025 \mathrm{~m}, 112 ; 0.035 \mathrm{~m}, 47$

water depth : near wave board $0.8 \mathrm{~m}$; at the structure $0.4 \mathrm{~m}$

wave steepness : 0.02 wave heights : $0.15 \mathrm{~m}, 0.20 \mathrm{~m}$

$0.04 \quad 0.15 \mathrm{~m}, 0.20 \mathrm{~m}, 0.25 \mathrm{~m}$

tests performed : $\quad$ toe height $0.08 \mathrm{~m}$, toe width $0.12 \mathrm{~m}$

number of stones used with $D_{n 50}: 0.017 \mathrm{~m}, 318 ; 0.025 \mathrm{~m}, 112 ; 0.035 \mathrm{~m}, 47$

water depth : near wave board $0.7 \mathrm{~m}$; at the structure $0.3 \mathrm{~m}$

wave steepness : 0.02 wave heights : $0.15 \mathrm{~m}, 0.20 \mathrm{~m}$

$0.03 \quad 0.20 \mathrm{~m}$

$0.04 \quad 0.15 \mathrm{~m}, 0.20 \mathrm{~m}, 0.25 \mathrm{~m}$

tests performed : $\quad$ toe height $0.15 \mathrm{~m}$, toe width $0.12 \mathrm{~m}$

number of stones used with $D_{n 50}: 0.025 \mathrm{~m}, 235 ; 0.035 \mathrm{~m}, 85 ; 0.040 \mathrm{~m}, 60$

water depth : near wave board $0.9 \mathrm{~m}$; at the structure $0.5 \mathrm{~m}$

wave steepness : $0.02 \quad$ wave heights $: 0.15 \mathrm{~m}, 0.20 \mathrm{~m}$

$0.04 \quad 0.15 \mathrm{~m}, 0.20 \mathrm{~m}, 0.25 \mathrm{~m}$

tests performed : $\quad$ toe height $0.15 \mathrm{~m}$, toe width $0.12 \mathrm{~m}$

number of stones used with $\mathrm{D}_{\mathrm{n} 50}: 0.025 \mathrm{~m}, 235 ; 0.035 \mathrm{~m}, 85 ; 0.040 \mathrm{~m}, 60$

water depth : near wave board $0.8 \mathrm{~m}$; at the structure $0.4 \mathrm{~m}$

wave steepness : $0.02 \quad$ wave heights : $0.15 \mathrm{~m}, 0.20 \mathrm{~m}$

$0.04 \quad 0.15 \mathrm{~m}, 0.20 \mathrm{~m}, 0.25 \mathrm{~m}$ 
Table 1: Overall view of tests performed (continued)

tests performed : $\quad$ toe height $0.15 \mathrm{~m}$, toe width $0.12 \mathrm{~m}$

number of stones used with $\mathrm{D}_{\mathrm{n} 50}: 0.025 \mathrm{~m}, 235 ; 0.035 \mathrm{~m}, 85 ; 0.040 \mathrm{~m}, 60$

water depth : near wave board $0.7 \mathrm{~m}$; at the structure $0.3 \mathrm{~m}$

wave steepness : 0.02

0.03

0.04 wave heights : $0.15 \mathrm{~m}, 0.20 \mathrm{~m}$

$0.20 \mathrm{~m}$

$0.15 \mathrm{~m}, 0.20 \mathrm{~m}, 0.25 \mathrm{~m}$

tests performed : toe height $0.22 \mathrm{~m}$, toe width $0.12 \mathrm{~m}$

number of stones used with $D_{\mathrm{n} 50}: 0.025 \mathrm{~m}, 350 ; 0.035 \mathrm{~m}, 124 ; 0.040 \mathrm{~m}, 85$

water depth : $\quad$ near wave board $0.9 \mathrm{~m}$; at the structure $0.5 \mathrm{~m}$

wave steepness : $0.02 \quad$ wave heights : $0.15 \mathrm{~m}, 0.20 \mathrm{~m}$

$0.04 \quad 0.15 \mathrm{~m}, 0.20 \mathrm{~m}, 0.25 \mathrm{~m}$

tests performed : $\quad$ toe height $0.22 \mathrm{~m}$, toe width $0.12 \mathrm{~m}$

number of stones used with $\mathrm{D}_{\mathrm{n} 50}: 0.025 \mathrm{~m}, 350 ; 0.035 \mathrm{~m}, 124 ; 0.040 \mathrm{~m}, 85$

water depth : $\quad$ near wave board $0.8 \mathrm{~m}$; at the structure $0.4 \mathrm{~m}$

wave steepness : 0.02 wave heights : $0.15 \mathrm{~m}, 0.20 \mathrm{~m}$

$0.04 \quad 0.15 \mathrm{~m}, 0.20 \mathrm{~m}, 0.25 \mathrm{~m}$

tests performed : $\quad$ toe height $0.15 \mathrm{~m}$, toe width $0.20 \mathrm{~m}$

number of stones used with $D_{n 50}: 0.025 \mathrm{~m}, 384 ; 0.035 \mathrm{~m}, 142 ; 0.040 \mathrm{~m}, 98$

water depth : near wave board $0.9 \mathrm{~m}$; at the structure $0.5 \mathrm{~m}$

wave steepness : $0.02 \quad$ wave heights : $0.15 \mathrm{~m}, 0.20 \mathrm{~m}, 0.25 \mathrm{~m}$

$0.04 \quad 0.15 \mathrm{~m}, 0.20 \mathrm{~m}, 0.25 \mathrm{~m}$

tests performed : toe height $0.15 \mathrm{~m}$, toe width $0.30 \mathrm{~m}$

number of stones used with $D_{n 50}: 0.025 \mathrm{~m}, 488 ; 0.035 \mathrm{~m}, 174 ; 0.040 \mathrm{~m}$,

119

water depth : $\quad$ near wave board $0.9 \mathrm{~m}$; at the structure $0.5 \mathrm{~m}$

wave steepness : 0.02 wave heights : $0.15 \mathrm{~m}, 0.20 \mathrm{~m}, 0.25 \mathrm{~m}$

$0.04 \quad 0.15 \mathrm{~m}, 0.20 \mathrm{~m}, 0.25$

foreshore : horizontal $11 \mathrm{~m}$

$1: 20 \quad 7 \mathrm{~m}$ 
TOE Deep Shallo TOE TOE DEEP WATER SHALLOW WATER

Test Armo Water Water Depth Width Wave Wave Wave Wave Wave Wave Dama No size depth depth above height height period period height height Dn50 h hm ht bt $\mathrm{HsO}_{\mathrm{H}} \%$ Tm $\mathrm{Tp}$ Hs $\mathrm{H}_{2} \%$

\begin{tabular}{|c|c|c|c|c|c|c|c|c|c|c|c|c|}
\hline & $\left(m^{\wedge} \wedge 3\right.$ & $(m)$ & $(m)$ & $(\mathrm{m})$ & (m) & $(m)$ & $(m)$ & (s) & (s) & $(m)$ & $(m)$ & (\%) \\
\hline$t 1$ & 0.017 & 0.9 & 0.5 & 0.42 & 0.12 & 0.161 & 0.234 & 1.36 & 1.56 & 0.151 & 0.22 & 1 \\
\hline t1 & 0.025 & 0.9 & 0.5 & 0.42 & 0.12 & 0.161 & 0.234 & 1.36 & 1.56 & 0.151 & 0.22 & 2 \\
\hline t1 & 0.035 & 0.9 & 0.5 & 0.42 & 0.12 & 0.161 & 0.234 & 1.36 & 1.56 & 0.151 & 0.22 & 0 \\
\hline$t 2$ & 0.017 & 0.9 & 0.5 & 0.42 & 0.12 & 0.16 & 0.241 & 1.83 & 2.16 & 0.162 & 0.23 & 2 \\
\hline t2 & 0.025 & 0.9 & 0.5 & 0.42 & 0.12 & 0.16 & 0.241 & 1.83 & 2.16 & 0.162 & 0.23 & 8 \\
\hline t2 & 0.035 & 0.9 & 0.5 & 0.42 & 0.12 & 0.16 & 0.241 & 1.83 & 2.16 & 0.162 & 0.23 & 2 \\
\hline t3 & 0.017 & 0.9 & 0.5 & 0.42 & 0.12 & 0.207 & 0.304 & 1.59 & 1.8 & 0.197 & 0.29 & 5 \\
\hline t3 & 0.025 & 0.9 & 0.5 & 0.42 & 0.12 & 0.207 & 0.304 & 1.59 & 1.8 & 0.197 & 0.29 & 7 \\
\hline t3 & 0.035 & 0.9 & 0.5 & 0.42 & 0.12 & 0.207 & 0.304 & 1.59 & 1.8 & 0.197 & 0.29 & 0 \\
\hline 14 & 0.017 & 0.9 & 0.5 & 0.42 & 0.12 & 0.206 & 0.312 & 1.78 & 2.05 & 0.204 & 0.302 & 4 \\
\hline t4 & 0.025 & 0.9 & 0.5 & 0.42 & 0.12 & 0.206 & 0.312 & 1.78 & 2.05 & 0.204 & 0.302 & 12 \\
\hline 14. & 0.035 & 0.9 & 0.5 & 0.42 & 0.12 & 0.206 & 0.312 & 1.78 & 2.05 & 0.204 & 0.302 & 2 \\
\hline t5 & 0.017 & 0.9 & 0.5 & 0.42 & 0.12 & 0.205 & 0.321 & 1.78 & 2.05 & 0.212 & 0.3 & 0 \\
\hline t5 & 0.025 & 0.9 & 0.5 & 0.42 & 0.12 & 0.205 & 0.321 & 1.78 & 2.05 & 0.212 & 0.3 & 5 \\
\hline t5 & 0.035 & 0.9 & 0.5 & 0.42 & 0.12 & 0.205 & 0.321 & 1.78 & 2.05 & 0.212 & 0.3 & 2 \\
\hline t6 & 0.017 & 0.9 & 0.5 & 0.42 & 0.12 & 0.192 & 0.315 & 2.83 & 3.58 & 0.218 & 0.368 & 6 \\
\hline t6 & 0.025 & 0.9 & 0.5 & 0.42 & 0.12 & 0.192 & 0.315 & 2.83 & 3.58 & 0.218 & 0.368 & 6 \\
\hline t6 & 0.035 & 0.9 & 0.5 & 0.42 & 0.12 & 0.192 & 0.315 & 2.83 & 3.58 & 0.218 & 0.368 & 4 \\
\hline 17 & 0.017 & 0.9 & 0.5 & 0.42 & 0.12 & 0.248 & 0.371 & 1.77 & 2.01 & 0.234 & 0.34 & 5 \\
\hline $\mathrm{t} 7$ & 0.025 & 0.9 & 0.5 & 0.42 & 0.12 & 0.248 & 0.371 & 1.77 & 2.01 & 0.234 & 0.34 & 13 \\
\hline $\mathrm{t} 7$ & 0.035 & 0.9 & 0.5 & 0.42 & 0.12 & 0.248 & 0.371 & 1.77 & 2.01 & 0.234 & 0.34 & 6 \\
\hline t8 & 0.017 & 0.9 & 0.5 & 0.42 & 0.12 & 0.238 & 0.372 & 2.48 & 2.86 & 0.239 & 0.34 & 6 \\
\hline t8 & 0.025 & 0.9 & 0.5 & 0.42 & 0.12 & 0.238 & 0.372 & 2.48 & 2.86 & 0.239 & 0.34 & 16 \\
\hline t8 & 0.035 & 0.9 & 0.5 & 0.42 & 0.12 & 0.238 & 0.372 & 2.48 & 2.86 & 0.239 & 0.34 & 9 \\
\hline tg & 0.017 & 0.7 & 0.3 & 0.22 & 0.12 & 0.155 & 0.225 & 1.39 & 1.56 & 0.141 & 0.193 & 3 \\
\hline 19 & 0.025 & 0.7 & 0.3 & 0.22 & 0.12 & 0.155 & 0.225 & 1.39 & 1.56 & 0.141 & 0.193 & 1 \\
\hline t9 & 0.035 & 0.7 & 0.3 & 0.22 & 0.12 & 0.155 & 0.225 & 1.39 & 1.56 & 0.141 & 0.193 & 0 \\
\hline
\end{tabular}


TOE Deep Shallo TOE TOE DEEP WATER SHALLOW WATER

Test Armo Water Water Depth Width Wave Wave Wave Wave Wave Wave Dama No size depth depth above height height period period height height Dn50 $h \quad h m$ ht bt $\mathrm{HsO} \quad \mathrm{H}_{2} \%$ Tm $\mathrm{Tp}$ Hs $\mathrm{H}_{2} \%$

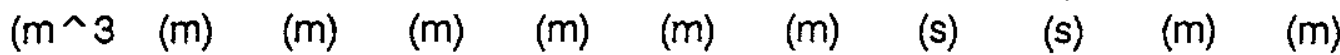

$\begin{array}{lllllllllllll}\text { t10 } & 0.017 & 0.7 & 0.3 & 0.22 & 0.12 & 0.155 & 0.235 & 1.83 & 2.25 & 0.154 & 0.232 & 2\end{array}$

$\begin{array}{lllllllllllll}\mathrm{t} 10 & 0.025 & 0.7 & 0.3 & 0.22 & 0.12 & 0.155 & 0.235 & 1.83 & 2.25 & 0.154 & 0.232 & 3\end{array}$

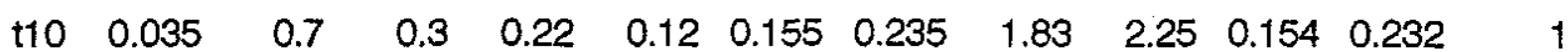

$\begin{array}{lllllllllllll}\mathrm{t} 11 & 0.017 & 0.7 & 0.3 & 0.22 & 0.12 & 0.199 & 0.287 & 1.6 & 1.83 & 0.169 & 0.232 & 11\end{array}$

$\begin{array}{lllllllllllll}\mathrm{t} 11 & 0.025 & 0.7 & 0.3 & 0.22 & 0.12 & 0.199 & 0.287 & 1.6 & 1.83 & 0.169 & 0.232 & 9\end{array}$

$\begin{array}{lllllllllllll}\mathrm{t} 11 & 0.035 & 0.7 & 0.3 & 0.22 & 0.12 & 0.199 & 0.287 & 1.6 & 1.83 & 0.169 & 0.232 & 0\end{array}$

$\begin{array}{lllllllllllll}\mathrm{t} 12 & 0.017 & 0.7 & 0.3 & 0.22 & 0.12 & 0.2 & 0.3 & 1.77 & 2.12 & 0.176 & 0.243 & 19\end{array}$

$\begin{array}{lllllllllllll}\mathrm{t} 12 & 0.025 & 0.7 & 0.3 & 0.22 & 0.12 & 0.2 & 0.3 & 1.77 & 2.12 & 0.176 & 0.243 & 20\end{array}$

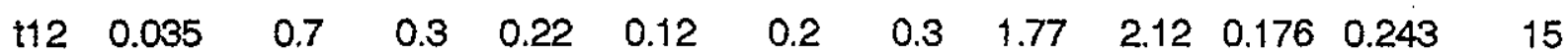

$\begin{array}{lllllllllllll}\mathrm{t} 13 & 0.017 & 0.7 & 0.3 & 0.22 & 0.12 & 0.198 & 0.312 & 2.03 & 2.56 & 0.181 & 0.275 & 15\end{array}$

$\begin{array}{lllllllllllll}\mathrm{t13} & 0.025 & 0.7 & 0.3 & 0.22 & 0.12 & 0.198 & 0.312 & 2.03 & 2.56 & 0.181 & 0.275 & 33\end{array}$

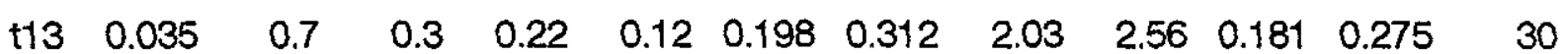

$\begin{array}{lllllllllllll}\mathrm{t} 15 & 0.017 & 0.7 & 0.3 & 0.22 & 0.12 & 0.23 & 0.33 & 1.75 & 2.04 & 0.184 & 0.252 & 19\end{array}$

$\begin{array}{lllllllllllll}\text { t15 } & 0.025 & 0.7 & 0.3 & 0.22 & 0.12 & 0.23 & 0.33 & 1.75 & 2.04 & 0.184 & 0.252 & 30\end{array}$

$\begin{array}{lllllllllllll}t 15 & 0.035 & 0.7 & 0.3 & 0.22 & 0.12 & 0.23 & 0.33 & 1.75 & 2.04 & 0.184 & 0.252 & 27\end{array}$

$\begin{array}{lllllllllllll}t 17 & 0.017 & 0.8 & 0.4 & 0.32 & 0.12 & 0.158 & 0.229 & 1.37 & 1.52 & 0.149 & 0.216 & 2\end{array}$

$\begin{array}{lllllllllllll}t 17 & 0.025 & 0.8 & 0.4 & 0.32 & 0.12 & 0.158 & 0.229 & 1.37 & 1.52 & 0.149 & 0.216 & 5\end{array}$

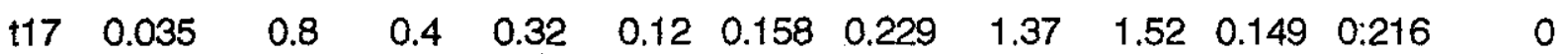

$\begin{array}{lllllllllllll}\mathrm{t} 18 & 0.017 & 0.8 & 0.4 & 0.32 & 0.12 & 0.158 & 0.241 & 1.83 & 2.21 & 0.162 & 0.219 & 7\end{array}$

$\begin{array}{lllllllllllll}\text { t18 } & 0.025 & 0.8 & 0.4 & 0.32 & 0.12 & 0.158 & 0.241 & 1.83 & 2.21 & 0.162 & 0.219 & 4\end{array}$

$\begin{array}{lllllllllllll}\text { t18 } & 0.035 & 0.8 & 0.4 & 0.32 & 0.12 & 0.158 & 0.241 & 1.83 & 2.21 & 0.162 & 0.219 & 0\end{array}$

$\begin{array}{lllllllllllll}\text { t19 } & 0.017 & 0.8 & 0.4 & 0.32 & 0.12 & 0.216 & 0.302 & 1.6 & 1.83 & 0.195 & 0.265 & 7\end{array}$

$\begin{array}{lllllllllllll}\mathrm{t} 19 & 0.025 & 0.8 & 0.4 & 0.32 & 0.12 & 0.216 & 0.302 & 1.6 & 1.83 & 0.195 & 0.265 & 5\end{array}$

$\begin{array}{lllllllllllll}\mathrm{t} 19 & 0.035 & 0.8 & 0.4 & 0.32 & 0.12 & 0.216 & 0.302 & 1.6 & 1.83 & 0.195 & 0.265 & 0\end{array}$

$\begin{array}{lllllllllllll}\text { t20 } & 0.017 & 0.8 & 0.4 & 0.32 & 0.12 & 0.201 & 0.316 & 2.13 & 2.57 & 0.2 & 0.32 & 7\end{array}$

$\begin{array}{lllllllllllll}\text { t20 } & 0.025 & 0.8 & 0.4 & 0.32 & 0.12 & 0.201 & 0.316 & 2.13 & 2.57 & 0.2 & 0.32 & 7\end{array}$

$\begin{array}{lllllllllllll}\mathrm{t} 20 & 0.035 & 0.8 & 0.4 & 0.32 & 0.12 & 0.201 & 0.316 & 2.13 & 2.57 & 0.2 & 0.32 & 4\end{array}$ 
TOE Deep Shallo TOE TOE DEEP WATER SHALLOW WATER

Test Armo Water Water Depth Width Wave Wave Wave Wave Wave Wave Dama No size depth depth above height height period period height height Dn50 h $\mathrm{hm}$ ht bt $\mathrm{HsO} \mathrm{H}_{2} \%$ Tm Tp Hs $\mathrm{H} 2 \%$ $\begin{array}{llllllllllll}(m \wedge & (m) & (m) & (m) & (m) & (m) & (m) & (s) & (s) & (m) & (m) & (\%)\end{array}$

$\begin{array}{lllllllllllll}\mathrm{t} 21 & 0.017 & 0.8 & 0.4 & 0.32 & 0.12 & 0.244 & 0.342 & 1.78 & 2.03 & 0.215 & 0.297 & 14\end{array}$ $\begin{array}{lllllllllllll}\text { t21 } & 0.025 & 0.8 & 0.4 & 0.32 & 0.12 & 0.244 & 0.342 & 1.78 & 2.03 & 0.215 & 0.297 & 12\end{array}$ $\begin{array}{lllllllllllll}\mathrm{t} 21 & 0.035 & 0.8 & 0.4 & 0.32 & 0.12 & 0.244 & 0.342 & 1.78 & 2.03 & 0.215 & 0.297 & 15\end{array}$

$\begin{array}{lllllllllllll}\text { t23 } & 0.025 & 0.9 & 0.5 & 0.35 & 0.12 & 0.163 & 0.232 & 1.36 & 1.56 & 0.151 & 0.222 & 1 \\ \text { t23 } & 0.035 & 0.9 & 0.5 & 0.35 & 0.12 & 0.163 & 0.232 & 1.36 & 1.56 & 0.151 & 0.222 & 0 \\ \text { t23 } & 0.040 & 0.9 & 0.5 & 0.35 & 0.12 & 0.163 & 0.232 & 1.36 & 1.56 & 0.151 & 0.222 & 0\end{array}$ $\begin{array}{lllllllllllll}\mathrm{t} 24 & 0.025 & 0.9 & 0.5 & 0.35 & 0.12 & 0.161 & 0.237 & 1.83 & 2.16 & 0.162 & 0.216 & 4\end{array}$ $\begin{array}{lllllllllllll}\mathrm{t} 24 & 0.035 & 0.9 & 0.5 & 0.35 & 0.12 & 0.161 & 0.237 & 1.83 & 2.16 & 0.162 & 0.216 & 1\end{array}$ $\begin{array}{lllllllllllll}\mathrm{t} 24 & 0.040 & 0.9 & 0.5 & 0.35 & 0.12 & 0.161 & 0.237 & 1.83 & 2.16 & 0.162 & 0.216 & 0\end{array}$

$\begin{array}{lllllllllllll}\text { t25 } & 0.025 & 0.9 & 0.5 & 0.35 & 0.12 & 0.208 & 0.299 & 1.59 & 1.8 & 0.197 & 0.288 & 12\end{array}$ $\begin{array}{lllllllllllll}\text { t25 } & 0.035 & 0.9 & 0.5 & 0.35 & 0.12 & 0.208 & 0.299 & 1.59 & 1.8 & 0.197 & 0.288 & 0\end{array}$ $\begin{array}{lllllllllllll}\text { t25 } & 0.040 & 0.9 & 0.5 & 0.35 & 0.12 & 0.208 & 0.299 & 1.59 & 1.8 & 0.197 & 0.288 & 2\end{array}$

$\begin{array}{lllllllllllll}\text { t26 } & 0.025 & 0.9 & 0.5 & 0.35 & 0.12 & 0.205 & 0.319 & 1.78 & 2.05 & 0.207 & 0.297 & 18\end{array}$ $\begin{array}{lllllllllllll}\text { t26 } & 0.035 & 0.9 & 0.5 & 0.35 & 0.12 & 0.205 & 0.319 & 1.78 & 2.05 & 0.207 & 0.297 & 9\end{array}$ $\begin{array}{lllllllllllll}\text { t26 } & 0.040 & 0.9 & 0.5 & 0.35 & 0.12 & 0.205 & 0.319 & 1.78 & 2.05 & 0.207 & 0.297 & 3\end{array}$

$\begin{array}{lllllllllllll}\text { t27 } & 0.025 & 0.9 & 0.5 & 0.35 & 0.12 & 0.251 & 0.368 & 1.77 & 2.01 & 0.234 & 0.337 & 23\end{array}$

$\begin{array}{lllllllllllll}\text { t27 } & 0.035 & 0.9 & 0.5 & 0.35 & 0.12 & 0.251 & 0.368 & 1.77 & 2.01 & 0.234 & 0.337 & 16\end{array}$

$\begin{array}{lllllllllllll}\text { t27 } & 0.040 & 0.9 & 0.5 & 0.35 & 0.12 & 0.251 & 0.368 & 1.77 & 2.01 & 0.234 & 0.337 & 18\end{array}$

$\begin{array}{lllllllllllll}\text { t29 } & 0.025 & 0.7 & 0.3 & 0.15 & 0.12 & 0.153 & 0.22 & 1.39 & 1.56 & 0.141 & 0.191 & 7 \\ \text { t29 } & 0.035 & 0.7 & 0.3 & 0.15 & 0.12 & 0.153 & 0.22 & 1.39 & 1.56 & 0.141 & 0.191 & 5 \\ \text { t29 } & 0.040 & 0.7 & 0.3 & 0.15 & 0.12 & 0.153 & 0.22 & 1.39 & 1.56 & 0.141 & 0.191 & 3\end{array}$

$\begin{array}{lllllllllllll}\text { t30 } & 0.025 & 0.7 & 0.3 & 0.15 & 0.12 & 0.154 & 0.23 & 1.83 & 2.25 & 0.154 & 0.229 & 16\end{array}$

$\begin{array}{lllllllllllll}\text { t30 } & 0.035 & 0.7 & 0.3 & 0.15 & 0.12 & 0.154 & 0.23 & 1.83 & 2.25 & 0.154 & 0.229 & 13\end{array}$

$\begin{array}{lllllllllllll}\text { t30 } & 0.040 & 0.7 & 0.3 & 0.15 & 0.12 & 0.154 & 0.23 & 1.83 & 2.25 & 0.154 & 0.229 & 5\end{array}$

$\begin{array}{lllllllllllll}\text { t31 } & 0.025 & 0.7 & 0.3 & 0.15 & 0.12 & 0.198 & 0.281 & 1.6 & 1.83 & 0.169 & 0.229 & 34\end{array}$

$\begin{array}{lllllllllllll}\text { t31 } & 0.035 & 0.7 & 0.3 & 0.15 & 0.12 & 0.198 & 0.281 & 1.6 & 1.83 & 0.169 & 0.229 & 22\end{array}$

$\begin{array}{lllllllllllll}\text { t31 } & 0.040 & 0.7 & 0.3 & 0.15 & 0.12 & 0.198 & 0.281 & 1.6 & 1.83 & 0.169 & 0.229 & 13\end{array}$ 
TOE Deep Shallo TOE TOE DEEP WATER SHALLOW WATER

Test Armo Water Water Depth Width Wave Wave Wave Wave Wave Wave Dama No size depth depth above height height period period height height Dn50 h $\mathrm{hm}$ ht bt $\mathrm{HsO}_{\mathrm{H}} \mathrm{H} \%$ Tm $\mathrm{Tp} H \mathrm{Hs}$ $\begin{array}{llllllllllllll}\left(m^{\wedge} 3\right. & (m) & (m) & (m) & (m) & (m) & (m) & (s) & (s) & (m) & (m) & (\%)\end{array}$

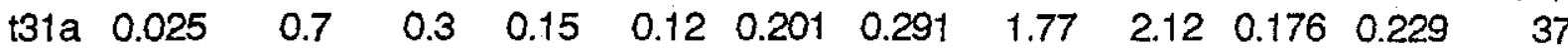
$\begin{array}{lllllllllllll}\text { t31a } & 0.035 & 0.7 & 0.3 & 0.15 & 0.12 & 0.201 & 0.291 & 1.77 & 2.12 & 0.176 & 0.229 & 22\end{array}$

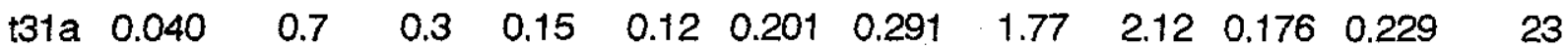

\begin{tabular}{|c|c|c|c|c|c|c|c|c|c|c|}
\hline $32 \quad 0.025$ & 0.7 & 0.3 & 0.15 & 0.12 & 0.196 & 0.305 & 2.03 & 2.56 & 0.181 & 0.271 \\
\hline t32 0.035 & 0.7 & 0.3 & 0.15 & 0.12 & 0.196 & 0.305 & 2.03 & 2.56 & 0.181 & 0.271 \\
\hline 320.040 & 0.7 & 0.3 & 0.15 & 0.12 & 0.196 & 0.305 & 2.03 & 2.56 & 0.181 & 0.271 \\
\hline 0.025 & 0.7 & 0.3 & 0.15 & 0.12 & 0.231 & 0.324 & 1.75 & 2.04 & 0.184 & 0.242 \\
\hline $3 \quad 0.035$ & 0.7 & 0.3 & 0.15 & 0.12 & 0.231 & 0.324 & 1.75 & 2.04 & 0.184 & 0.242 \\
\hline $3 \quad 0.040$ & 0.7 & 0.3 & 0.15 & 0.12 & 0.231 & 0.324 & 1.75 & 2.04 & 0.184 & 0.242 \\
\hline 0.025 & 0.8 & 0.4 & 0.25 & 0.12 & 0.16 & 0.226 & 1.37 & 1.52 & 0.149 & 0.216 \\
\hline 0.035 & 0.8 & 0.4 & 0.25 & 0.12 & 0.16 & 0.226 & 1.37 & 1.52 & 0.149 & 0.216 \\
\hline 0.040 & 0.8 & 0.4 & 0.25 & 0.12 & 0.16 & 0.226 & 1.37 & 1.52 & 0.149 & 0.216 \\
\hline 0.025 & 0.8 & 0.4 & 0.25 & 0.12 & 0.158 & 0.237 & 1.83 & 2.21 & 0.162 & 0.216 \\
\hline 0.035 & 0.8 & 0.4 & 0.25 & 0.12 & 0.158 & 0.237 & 1.83 & 2.21 & 0.162 & 0.216 \\
\hline 0.040 & 0.8 & 0.4 & 0.25 & 0.12 & 0.158 & 0.237 & 1.83 & 2.21 & 0.162 & 0.216 \\
\hline 0.025 & 0.8 & 0.4 & 0.25 & 0.12 & 0.204 & 0.296 & 1.6 & 1.83 & 0.188 & 0.261 \\
\hline 0.035 & 0.8 & 0.4 & 0.25 & 0.12 & 0.204 & 0.296 & 1.6 & 1.83 & 0.188 & 0.261 \\
\hline 0.040 & 0.8 & 0.4 & 0.25 & 0.12 & 0.204 & 0.296 & 1.6 & 1.83 & 0.188 & 0.261 \\
\hline 0.025 & 0.8 & 0.4 & 0.25 & 0.12 & 0.201 & 0.316 & 2.13 & 2.57 & 0.199 & 0.317 \\
\hline 0.035 & 0.8 & 0.4 & 0.25 & 0.12 & 0.201 & 0.316 & 2.13 & 2.57 & 0.199 & 0.317 \\
\hline 0.040 & 0.8 & 0.4 & 0.25 & 0.12 & 0.201 & 0.316 & 2.13 & 2.57 & 0.199 & 0.317 \\
\hline 0.025 & 0.8 & 0.4 & 0.25 & 0.12 & 0.244 & 0.346 & 1.78 & 2.03 & 0.215 & 0.294 \\
\hline 0.035 & 0.8 & 0.4 & 0.25 & 0.12 & 0.244 & 0.346 & 1.78 & 2.03 & 0.215 & 0.294 \\
\hline 0.040 & 0.8 & 0.4 & 0.25 & 0.12 & 0.244 & 0.346 & 1.78 & 2.03 & 0.215 & 0.294 \\
\hline 0.025 & 0.9 & 0.5 & 0.28 & 0.12 & 0.162 & 0.232 & 1.36 & 1.56 & 0.151 & 0.222 \\
\hline 0.035 & 0.9 & 0.5 & 0.28 & 0.12 & 0.162 & 0.232 & 1.36 & 1.56 & 0.151 & 0.222 \\
\hline 0.040 & 0.9 & 0.5 & 0.28 & 0.12 & 0.162 & 0.232 & 1.36 & 1.56 & 0.151 & 0.222 \\
\hline
\end{tabular}


TOE Deep Shallo TOE TOE DEEP WATER SHALLOW WATER

Test Armo Water Water Depth Width Wave Wave Wave Wave Wave Wave Dama No size depth depth above height height period period height height

Dn50 h $\mathrm{hm}$ ht bt $\mathrm{HsO} \mathrm{H}_{2} \%$ Tm $\mathrm{Tp}$ Hs $\mathrm{H} 2 \%$
$\left(m^{\wedge} 3(m)\right.$
(m)
(m)
(m) (m) (m)
(s)
(s) (m) (m)

(\%)

$\begin{array}{rrrrrrrrrrrrr}\mathrm{t} 42 & 0.025 & 0.9 & 0.5 & 0.28 & 0.12 & 0.159 & 0.236 & 1.83 & 2.16 & 0.162 & 0.222 & 5 \\ \mathrm{t} 42 & 0.035 & 0.9 & 0.5 & 0.28 & 0.12 & 0.159 & 0.236 & 1.83 & 2.16 & 0.162 & 0.222 & 2 \\ \mathrm{t} 42 & 0.040 & 0.9 & 0.5 & 0.28 & 0.12 & 0.159 & 0.236 & 1.83 & 2.16 & 0.162 & 0.222 & 2 \\ & & & & & & & & & & & & \\ \mathrm{t} 43 & 0.025 & 0.9 & 0.5 & 0.28 & 0.12 & 0.207 & 0.297 & 1.59 & 1.8 & 0.197 & 0.288 & 10 \\ \mathrm{t} 43 & 0.035 & 0.9 & 0.5 & 0.28 & 0.12 & 0.207 & 0.297 & 1.59 & 1.8 & 0.197 & 0.288 & 9 \\ \mathrm{t} 43 & 0.040 & 0.9 & 0.5 & 0.28 & 0.12 & 0.207 & 0.297 & 1.59 & 1.8 & 0.197 & 0.288 & 5\end{array}$

$\begin{array}{lllllllllllll}\text { t44 } & 0.025 & 0.9 & 0.5 & 0.28 & 0.12 & 0.204 & 0.316 & 1.78 & 2.05 & 0.207 & 0.294 & 13\end{array}$

$\begin{array}{lllllllllllll}\mathrm{t} 44 & 0.035 & 0.9 & 0.5 & 0.28 & 0.12 & 0.204 & 0.316 & 1.78 & 2.05 & 0.207 & 0.294 & 7\end{array}$

$\begin{array}{lllllllllllll}\text { t44 } & 0.040 & 0.9 & 0.5 & 0.28 & 0.12 & 0.204 & 0.316 & 1.78 & 2.05 & 0.207 & 0.294 & 10\end{array}$

$\begin{array}{lllllllllllll}145 & 0.025 & 0.9 & 0.5 & 0.28 & 0.12 & 0.25 & 0.369 & 1.77 & 2.01 & 0.234 & 0.337 & 22\end{array}$

$\begin{array}{lllllllllllll}t 45 & 0.035 & 0.9 & 0.5 & 0.28 & 0.12 & 0.25 & 0.369 & 1.77 & 2.01 & 0.234 & 0.337 & 11\end{array}$

$\begin{array}{lllllllllllll}\mathrm{t} 45 & 0.040 & 0.9 & 0.5 & 0.28 & 0.12 & 0.25 & 0.369 & 1.77 & 2.01 & 0.234 & 0.337 & 12\end{array}$

$\begin{array}{lllllllllllll}\mathrm{t} 47 & 0.025 & 0.8 & 0.4 & 0.18 & 0.12 & 0.159 & 0.227 & 1.37 & 1.52 & 0.149 & 0.216 & 6\end{array}$

$\begin{array}{lllllllllllll}\text { t47 } & 0.035 & 0.8 & 0.4 & 0.18 & 0.12 & 0.159 & 0.227 & 1.37 & 1.52 & 0.149 & 0.216 & 5\end{array}$

$\begin{array}{lllllllllllll}\mathrm{t} 47 & 0.040 & 0.8 & 0.4 & 0.18 & 0.12 & 0.159 & 0.227 & 1.37 & 1.52 & 0.149 & 0.216 & 2\end{array}$

$\begin{array}{lllllllllllll}\mathrm{t} 48 & 0.025 & 0.8 & 0.4 & 0.18 & 0.12 & 0.158 & 0.234 & 1.83 & 2.21 & 0.162 & 0.209 & 11\end{array}$

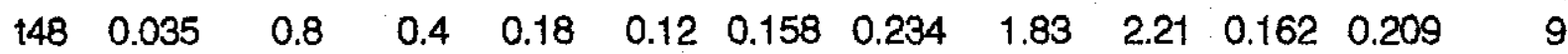

$\begin{array}{lllllllllllll}148 & 0.040 & 0.8 & 0.4 & 0.18 & 0.12 & 0.158 & 0.234 & 1.83 & 2.21 & 0.162 & 0.209 & 1\end{array}$

$\begin{array}{lllllllllllll}\text { t49 } & 0.025 & 0.8 & 0.4 & 0.18 & 0.12 & 0.204 & 0.29 & 1.6 & 1.83 & 0.188 & 0.261 & 18\end{array}$

$\begin{array}{lllllllllllll}t 49 & 0.035 & 0.8 & 0.4 & 0.18 & 0.12 & 0.204 & 0.29 & 1.6 & 1.83 & 0.188 & 0.261 & 13\end{array}$

$\begin{array}{lllllllllllll}\text { t49 } & 0.040 & 0.8 & 0.4 & 0.18 & 0.12 & 0.204 & 0.29 & 1.6 & 1.83 & 0.188 & 0.261 & 8\end{array}$

$\begin{array}{lllllllllllll}\text { t50 } & 0.025 & 0.8 & 0.4 & 0.18 & 0.12 & 0.2 & 0.313 & 2.13 & 2.57 & 0.199 & 0.317 & 26\end{array}$

$\begin{array}{lllllllllllll}\text { t50 } & 0.035 & 0.8 & 0.4 & 0.18 & 0.12 & 0.2 & 0.313 & 2.13 & 2.57 & 0.199 & 0.317 & 18\end{array}$

$\begin{array}{lllllllllllll}\text { t50 } & 0.040 & 0.8 & 0.4 & 0.18 & 0.12 & 0.2 & 0.313 & 2.13 & 2.57 & 0.199 & 0.317 & 13\end{array}$

$\begin{array}{lllllllllllll}t 51 & 0.025 & 0.8 & 0.4 & 0.18 & 0.12 & 0.244 & 0.346 & 1.78 & 2.03 & 0.215 & 0.291 & 30\end{array}$

$\begin{array}{lllllllllllll}151 & 0.035 & 0.8 & 0.4 & 0.18 & 0.12 & 0.244 & 0.346 & 1.78 & 2.03 & 0.215 & 0.291 & 20\end{array}$

$\begin{array}{lllllllllllll}\text { t51 } & 0.040 & 0.8 & 0.4 & 0.18 & 0.12 & 0.244 & 0.346 & 1.78 & 2.03 & 0.215 & 0.291 & 14\end{array}$ 
TOE Deep Shallo TOE TOE DEEP WATER SHALLOW WATER

Test Armo Water Water Depth Width Wave Wave Wave Wave Wave Wave Dama No size depth depth above

height height period period height height

Dn50 h hm ht bt $\mathrm{HsO} \mathrm{H}_{2 \%} \mathrm{Tm}$ Tp $\mathrm{Hs} H 2 \%$

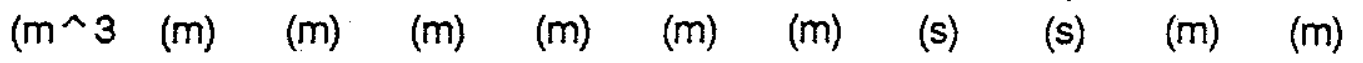

(\%)

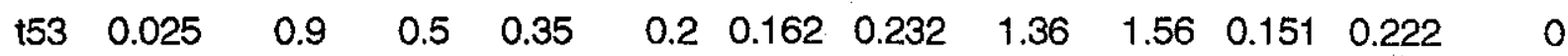

$\begin{array}{llllllllllllll}\mathrm{t} 53 & 0.035 & 0.9 & 0.5 & 0.35 & 0.2 & 0.162 & 0.232 & 1.36 & 1.56 & 0.151 & 0.222 & 0\end{array}$

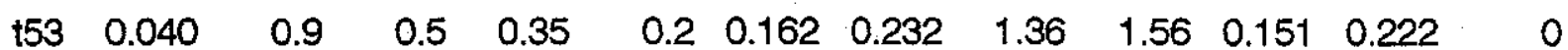

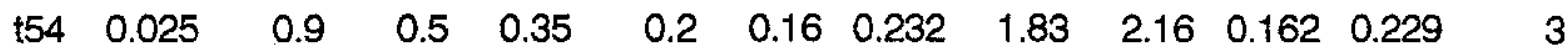

$\begin{array}{llllllllllllll}\text { t54 } & 0.035 & 0.9 & 0.5 & 0.35 & 0.2 & 0.16 & 0.232 & 1.83 & 2.16 & 0.162 & 0.229 & 3\end{array}$

$\begin{array}{lllllllllllll}\text { t54 } & 0.040 & 0.9 & 0.5 & 0.35 & 0.2 & 0.16 & 0.232 & 1.83 & 2.16 & 0.162 & 0.229 & 0\end{array}$

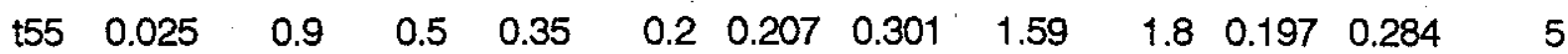

$\begin{array}{lllllllllllll}\text { t55 } & 0.035 & 0.9 & 0.5 & 0.35 & 0.2 & 0.207 & 0.301 & 1.59 & 1.8 & 0.197 & 0.284 & 3\end{array}$

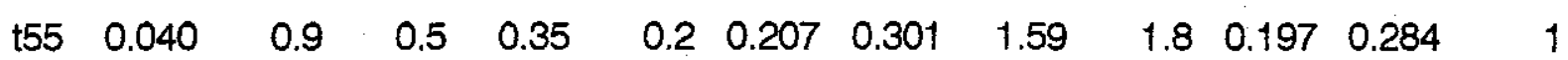

$\begin{array}{rrrrrrrrrrrrr}\text { t56 } & 0.025 & 0.9 & 0.5 & 0.35 & 0.2 & 0.204 & 0.315 & 1.78 & 2.05 & 0.207 & 0.294 & 14 \\ t 56 & 0.035 & 0.9 & 0.5 & 0.35 & 0.2 & 0.204 & 0.315 & 1.78 & 2.05 & 0.207 & 0.294 & 8 \\ \text { t56 } & 0.040 & 0.9 & 0.5 & 0.35 & 0.2 & 0.204 & 0.315 & 1.78 & 2.05 & 0.207 & 0.294 & 6\end{array}$

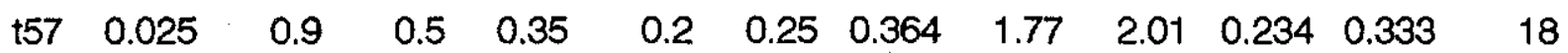

$\begin{array}{lllllllllllll}\text { t57 } & 0.035 & 0.9 & 0.5 & 0.35 & 0.2 & 0.25 & 0.364 & 1.77 & 2.01 & 0.234 & 0.333 & 7\end{array}$

$\begin{array}{lllllllllllll}\text { t57 } & 0.040 & 0.9 & 0.5 & 0.35 & 0.2 & 0.25 & 0.364 & 1.77 & 2.01 & 0.234 & 0.333 & 11\end{array}$

$\begin{array}{lllllllllllll}\text { t58 } & 0.025 & 0.9 & 0.5 & 0.35 & 0.2 & 0.241 & 0.382 & 2.35 & 2.86 & 0.243 & 0.356 & 24\end{array}$

$\begin{array}{lllllllllllll}\text { t58 } & 0.035 & 0.9 & 0.5 & 0.35 & 0.2 & 0.241 & 0.382 & 2.35 & 2.86 & 0.243 & 0.356 & 16\end{array}$

$\begin{array}{lllllllllllll}\text { t58 } & 0.040 & 0.9 & 0.5 & 0.35 & 0.2 & 0.241 & 0.382 & 2.35 & 2.86 & 0.243 & 0.356 & 16\end{array}$

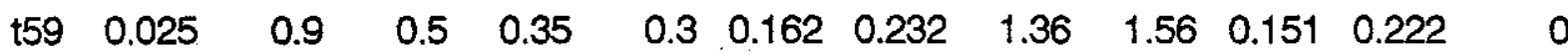

$\begin{array}{lllllllllllll}\text { t59 } & 0.035 & 0.9 & 0.5 & 0.35 & 0.3 & 0.162 & 0.232 & 1.36 & 1.56 & 0.151 & 0.222 & 1\end{array}$

$\begin{array}{lllllllllllll}t 59 & 0.040 & 0.9 & 0.5 & 0.35 & 0.3 & 0.162 & 0.232 & 1.36 & 1.56 & 0.151 & 0.222 & 0\end{array}$

$\begin{array}{lllllllllllll}t 60 & 0.025 & 0.9 & 0.5 & 0.35 & 0.3 & 0.161 & 0.236 & 1.83 & 2.16 & 0.162 & 0.229 & 5\end{array}$

$\begin{array}{lllllllllllll}\text { t60 } & 0.035 & 0.9 & 0.5 & 0.35 & 0.3 & 0.161 & 0.236 & 1.83 & 2.16 & 0.162 & 0.229 & 2\end{array}$

$\begin{array}{lllllllllllll}t 60 & 0.040 & 0.9 & 0.5 & 0.35 & 0.3 & 0.161 & 0.236 & 1.83 & 2.16 & 0.162 & 0.229 & 1\end{array}$

$\begin{array}{lllllllllllll}161 & 0.025 & 0.9 & 0.5 & 0.35 & 0.3 & 0.207 & 0.298 & 1.59 & 1.8 & 0.197 & 0.288 & 5\end{array}$

$\begin{array}{lllllllllllll}t 61 & 0.035 & 0.9 & 0.5 & 0.35 & 0.3 & 0.207 & 0.298 & 1.59 & 1.8 & 0.197 & 0.288 & 2\end{array}$

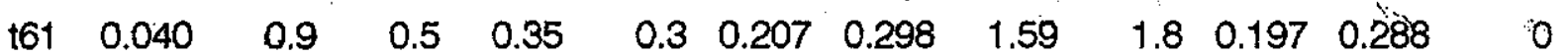




\begin{tabular}{|c|c|c|c|c|c|c|c|c|c|c|c|c|}
\hline est & $\begin{array}{c}\text { TOE } \\
\text { Armo } \\
\text { size }\end{array}$ & $\begin{array}{l}\text { Deep } \\
\text { Water } \\
\text { depth }\end{array}$ & $\begin{array}{l}\text { Shallo } \\
\text { Water } \\
\text { depth }\end{array}$ & $\begin{array}{l}\text { TOE } \\
\text { Depth } \\
\text { above }\end{array}$ & $\begin{array}{l}\text { TOE } \\
\text { Width }\end{array}$ & $\begin{array}{l}\text { DEE } \\
\text { Wave } \\
\text { height }\end{array}$ & $\begin{array}{l}\text { EP WAT } \\
\text { Wave } \\
\text { height }\end{array}$ & $\begin{array}{l}\text { Wave } \\
\text { period }\end{array}$ & $\begin{array}{l}\text { SHALL } \\
\text { Wave } \\
\text { period }\end{array}$ & $\begin{array}{l}\text { OW } V \\
\text { Wave } \\
\text { height }\end{array}$ & $\begin{array}{l}\text { WATER } \\
\text { Wave } \\
\text { it height }\end{array}$ & Dama \\
\hline & $\begin{array}{l}\text { Dn50 } \\
\left(\mathrm{m}^{\wedge} 3\right.\end{array}$ & $\begin{array}{l}\mathrm{h} \\
\text { (m) }\end{array}$ & $\begin{array}{l}\mathrm{hm} \\
(\mathrm{m})\end{array}$ & $\begin{array}{l}\mathrm{ht} \\
(\mathrm{m})\end{array}$ & $\begin{array}{l}\text { bt } \\
\text { (m) }\end{array}$ & $\begin{array}{l}\mathrm{HsO} \\
(\mathrm{m})\end{array}$ & $\begin{array}{l}\mathrm{H} 2 \% \\
\text { (m) }\end{array}$ & $\begin{array}{l}\mathrm{Tm} \\
\text { (s) }\end{array}$ & $\begin{array}{l}T p \\
\text { (s) }\end{array}$ & $\begin{array}{l}\mathrm{Hs} \\
\text { (m) }\end{array}$ & $\begin{array}{l}\mathrm{H} 2 \% \\
(\mathrm{~m})\end{array}$ & (\%) \\
\hline 62 & 0.025 & 0.9 & 0.5 & 0.35 & 0.3 & 0.204 & 0.311 & 1.78 & 2.05 & 0.207 & 0.291 & 10 \\
\hline 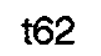 & 0.035 & 0.9 & 0.5 & 0.35 & 0.3 & 0.204 & 0.311 & 1.78 & 2.05 & 0.207 & 0.291 & 5 \\
\hline n & 0.040 & 0.9 & 0.5 & 0.35 & 0.3 & 0.204 & 0.311 & 1.78 & 2.05 & 0.207 & 0.291 & 0 \\
\hline & 0.025 & 0.9 & 0.5 & 0.35 & 0.3 & 0.251 & 0.364 & 1.77 & 2.01 & 0.234 & 0.333 & 10 \\
\hline & 0.035 & 0.9 & 0.5 & 0.35 & 0.3 & 0.25 & 0.364 & 1.77 & 2.01 & 0.234 & 0.333 & 5 \\
\hline & 0.040 & 0.9 & 0.5 & 0.35 & 0.3 & 0.25 & 0.364 & 1.77 & 2.01 & 0.234 & 0.333 & 1 \\
\hline & 0.025 & 0.9 & 0.5 & 0.35 & 0.3 & 0.244 & 0.389 & 2.35 & 2.86 & 0.244 & 0.359 & 10 \\
\hline & 0.035 & 0.9 & 0.5 & 0.35 & 0.3 & 0.244 & 0.389 & 2.35 & 2.86 & 0.244 & 0.359 & 12 \\
\hline & 0.040 & 0.9 & 0.5 & 0.35 & 0.3. & .0 .244 & 0.389 & 2.35 & 2.86 & 0.244 & 0.359 & 6 \\
\hline
\end{tabular}




\begin{tabular}{|c|c|c|c|c|c|c|c|c|c|c|c|}
\hline $\begin{array}{l}\text { Test } \\
\text { No }\end{array}$ & $\begin{array}{l}\text { Dama } \\
\text { Nod }\end{array}$ & $\begin{array}{l}\text { Test } \\
\text { No }\end{array}$ & $\begin{array}{l}\text { Dama } \\
\text { Nod }\end{array}$ & $\begin{array}{l}\text { Test } \\
\text { No }\end{array}$ & $\begin{array}{c}\text { Dama } \\
\text { Nod }\end{array}$ & $\begin{array}{l}\text { Test } \\
\text { No }\end{array}$ & $\begin{array}{c}\text { Dama } \\
\text { Nod }\end{array}$ & $\begin{array}{l}\text { Test } \\
\text { No }\end{array}$ & $\begin{array}{c}\text { Dama } \\
\text { Nod }\end{array}$ & $\begin{array}{c}\text { Test } \\
\text { No }\end{array}$ & $\begin{array}{c}\text { Dama } \\
\text { Nod }\end{array}$ \\
\hline$t 1-1$ & 0.18 & $t 11-1$ & 2.12 & $t 24-1$ & 0.96 & t35-1 & 2.02 & t47-1 & 1.93 & t58-1 & 7.98 \\
\hline$t 1-2$ & 0.26 & $t 11-2$ & 0.7 & $t 24-2$ & 0.14 & $t 35-2$ & 1.1 & $t 47-2$ & 0.82 & t58-2 & 3.01 \\
\hline$t 1-3$ & 0 & $\mathrm{t} 11-3$ & 0 & $\mathrm{t} 24-3$ & 0 & t35-3 & 0.15 & $\mathrm{t} 47-3$ & 0.3 & t58-3 & 2.42 \\
\hline t2-1 & 0.3 & $t 12-1$ & 3.7 & t25-t & 2.46 & t36-1 & 1.49 & $t 48-1$ & 3.42 & t59-1 & 0 \\
\hline t2-2 & 0.79 & $t 12-2$ & 1.93 & t25-2 & 0 & t36-2 & 1.09 & $\mathrm{t} 488-2$ & 1.37 & t59-2 & 0.14 \\
\hline t2-3 & 0.14 & $\mathrm{t} 12-3$ & 0.96 & t25-3 & 0.15 & t36-3 & 0.15 & t48-3 & 0.15 & t59-3 & 0 \\
\hline t3-1 & 0.97 & $t 13-1$ & 2.91 & t26-1 & 3.68 & t37-1 & 2.11 & t49-1 & 5.43 & t60-1 & 1.84 \\
\hline t3-2 & 0.7 & $t 13-2$ & 3.24 & $\mathrm{t} 26-2$ & 1.1 & t37-2 & 0.96 & $\mathrm{t} 49-2$ & 2.19 & t60-2 & 0.28 \\
\hline t3-3 & 0 & $t 13-3$ & 1.92 & t26-3 & 0.3 & t37-3 & 0.3 & t49-3 & 1.06 & $t 60-3$ & 0.15 \\
\hline$t 4-1$ & 0.85 & $\mathrm{t} 15-\mathrm{t}$ & 3.7 & $\mathrm{t} 27-1$ & 4.83 & t38-1 & 4.47 & t50-1 & 7.89 & $t 61-1$ & 1.84 \\
\hline$t 4-2$ & 1.14 & t15-2 & 2.63 & $\mathrm{t} 27-2$ & 1.92 & t38-2 & 1.64 & t50-2 & 3.01 & $t 61-2$ & 0.28 \\
\hline$t 4-3$ & 0.14 & $t 15-3$ & 1.78 & $\mathrm{t} 27-3$ & 1.67 & t38-3 & 0.76 & t50-3 & 1.67 & t61-3 & 0.15 \\
\hline t5-1 & 1.09 & $t 17-1$ & 0.36 & $t 29-1$ & 1.4 & t39-1 & 5.35 & t51-1 & 9.21 & t62-1 & 4.56 \\
\hline t5-2 & 0.44 & $\mathrm{t} 17-2$ & 0.53 & เ29-2 & 0.55 & t39-2 & 2.32 & t51-2 & 3.42 & t62-2 & 1.1 \\
\hline t5-3 & 0.14 & $\pm 17-3$ & 0 & t29-3 & 0.3 & t39-3 & 1.81 & $\pm 51-3$ & 1.82 & $t 62-3$ & 0 \\
\hline t6-1 & 1.15 & t18-1 & 1.33 & $130-1$ & 3.33 & $\mathrm{t} 441-1$ & 0.35 & t53-1 & 0 & t63-1 & 6.85 \\
\hline t6-2 & 0.61 & t18-2 & 0.35 & t3o-2 & 1.55 & t41-2 & 0.14 & t53-2 & $=0$ & t63-2 & 1.23 \\
\hline t6-3 & 0.27 & t18-3 & 0 & t30-3 & 0.45 & t41-3 & 0 & t53-3 & 0 & t63-3 & 0.15 \\
\hline t7-1 & 0.97 & $\mathrm{t} 19-1$ & 1.39 & t31- & 7.1 & $t 42-1$ & 1.49 & t54-1 & 0.96 & $t 64-1$ & 7.98 \\
\hline t7-2 & 1.32 & $\mathrm{t} 19-2$ & 0.53 & $\mathrm{t} 31-2$ & 2.6 & $\mathrm{t} 42-2$ & 0.27 & t54-2 & 0.55 & t64-2 & 2.88 \\
\hline $\mathrm{t} 7-3$ & 0.41 & $\mathrm{t} 19-3$ & 0 & $\mathrm{t} 31-3$ & 1.21 & $\mathrm{t} 42-3$ & 0.3 & t54-3 & 0 & t64-3 & 1.06 \\
\hline t8-1 & 1.09 & t20-1 & 0.97 & $\pm 31 a-1$ & 7.54 & $t 43-1$ & 3.33 & t55- 1 & 1.75 & & \\
\hline t8-2 & 1.58 & t2o-2 & 0.7 & t31a-2 & 2.6 & $t 43-2$ & 1.51 & t55-2 & 0.55 & & \\
\hline t8-3 & 0.55 & t20-3 & 0.27 & t31a-3 & 2.12 & t43-3 & 0.61 & t55-3 & 0.15 & & \\
\hline $9-1$ & 0.61 & $\mathrm{t} 21-1$ & 2.7 & t32-1 & 8.07 & t44-1 & 4.03 & t56-1 & 4.73 & & \\
\hline t9-2 & 0.09 & t21-2 & 1.05 & t32-2 & 4.25 & $\mathrm{t} 44-2$ & 1.23 & t56-2 & 1.64 & & \\
\hline t9-3 & 0 & $\mathrm{t} 21-3$ & 0.96 & t32-3 & 2.73 & $t 44-3$ & 1.36 & t56-3 & 0.91 & & \\
\hline-1 & 0.24 & t23-1 & 0.18 & t33-1 & 8.16 & $145-1$ & 6.84 & t57-1 & 5.87 & & \\
\hline-2 & 0.26 & t23-2 & 0 & t33-2 & 3.84 & t45-2 & 1.78 & t57-2 & 1.37 & & \\
\hline $110-3$ & 0.14 & t23-3 & 0 & t33-3 & 2.42 & $t 45-3$ & 1.51 & t57-3 & 1.66 & & \\
\hline
\end{tabular}




$\begin{array}{cccccccc}\text { Deep } & \text { Shallow } & \text { TOE } & \text { TOE } & \text { TOE } & \text { SHALLOW WATER } & \\ \text { Water } & \text { Water } & \text { Depth } & \text { Width } & \text { Armour } & \text { Wave } & \text { Wave } & \text { Nod } \\ \text { depth } & \text { depth } & \text { above to } & & \text { size } & \text { height } & \text { period } & \\ \text { h } & \text { hm } & \text { ht } & \text { bt } & \text { Dn50 } & \text { Hs } & \text { Tp } & \end{array}$
(m)
(m) (m)
(m) $\quad\left(m^{\wedge} 3\right) \quad(m)$
(s)

$\begin{array}{lllllllll}\text { REL0702 } & 0.7 & 0.3 & 0.22 & 0.12 & 0.017 & 0.155 & 2.22 & 0.5 \\ \text { REL0702 } & 0.7 & 0.3 & 0.22 & 0.12 & 0.025 & 0.155 & 2.22 & 0.5 \\ \text { REL0702 } & 0.7 & 0.3 & 0.22 & 0.12 & 0.035 & 0.16 & 2.28 & 0.5 \\ & & & & & & & & \\ \text { REL0702 } & 0.7 & 0.3 & 0.22 & 0.12 & 0.017 & 0.169 & 2.39 & 2 \\ \text { REL0702 } & 0.7 & 0.3 & 0.22 & 0.12 & 0.025 & 0.172 & 2.45 & 2 \\ \text { REL0702 } & 0.7 & 0.3 & 0.22 & 0.12 & 0.035 & 0.182 & 2.62 & 2 \\ & & & & & & & & \\ \text { REL0702 } & 0.7 & 0.3 & 0.22 & 0.12 & 0.017 & 0.187 & 2.74 & 4 \\ \text { REL0702 } & 0.7 & 0.3 & 0.22 & 0.12 & 0.025 & 0.192 & 2.83 & 4 \\ \text { REL0702 } & 0.7 & 0.3 & 0.22 & 0.12 & 0.035 & 0.212 & 3.26 & 4 \\ & & & & & & & & \\ \text { REL0704 } & 0.7 & 0.3 & 0.22 & 0.12 & 0.017 & 0.137 & 1.53 & 0.5 \\ \text { REL0704 } & 0.7 & 0.3 & 0.22 & 0.12 & 0.025 & 0.164 & 1.76 & 0.5 \\ \text { REL0704 } & 0.7 & 0.3 & 0.22 & 0.12 & 0.035 & 0.174 & 1.88 & 0.5 \\ & & & & & & & & \\ \text { REL0704 } & 0.7 & 0.3 & 0.22 & 0.12 & 0.017 & 0.167 & 1.79 & 2 \\ \text { REL0704 } & 0.7 & 0.3 & 0.22 & 0.12 & 0.025 & 0.181 & 1.99 & 2 \\ \text { REL0704 } & 0.7 & 0.3 & 0.22 & 0.12 & 0.035 & 0.185 & 2.04 & 2 \\ & & & & & & & & \\ \text { REL0704 } & 0.7 & 0.3 & 0.22 & 0.12 & 0.017 & 0.185 & 2.04 & 4 \\ \text { REL0704 } & 0.7 & 0.3 & 0.22 & 0.12 & 0.025 & 0.188 & 2.08 & 4 \\ \text { REL0704 } & 0.7 & 0.3 & 0.22 & 0.12 & 0.035 & 0.191 & 2.12 & 4 \\ & & & & & & & & \\ \text { REL0802 } & 0.8 & 0.4 & 0.32 & 0.12 & 0.017 & - & & 0.5 \\ \text { REL0802 } & 0.8 & 0.4 & 0.32 & 0.12 & 0.025 & 0.172 & 2.26 & 0.5 \\ \text { REL0802 } & 0.8 & 0.4 & 0.32 & 0.12 & 0.035 & 0.227 & 2.79 & 0.5 \\ & & & & & & & & \\ \text { REL0802 } & 0.8 & 0.4 & 0.32 & 0.12 & 0.017 & - & & 2 \\ \text { REL0802 } & 0.8 & 0.4 & 0.32 & 0.12 & 0.025 & - & & 2 \\ \text { REL0802 } & 0.8 & 0.4 & 0.32 & 0.12 & 0.035 & - & & 2 \\ & & & & & & & & \\ \text { REL0802 } & 0.8 & 0.4 & 0.32 & 0.12 & 0.017 & - & & 4 \\ \text { REL0802 } & 0.8 & 0.4 & 0.32 & 0.12 & 0.025 & - & & 4 \\ \text { REL0802 } & 0.8 & 0.4 & 0.32 & 0.12 & 0.035 & - & & 4\end{array}$




$\begin{array}{cccccccc}\text { Deep } & \text { Shallow } & \text { TOE } & \text { TOE } & \text { TOE } & \text { SHALLOW WATER } & \\ \text { Water } & \text { Water Depth. } & \text { Width } & \text { Armour } & \text { Wave } & \text { Wave } & \text { Nod } \\ \text { depth } & \text { depth above to } & & \text { size } & \text { height } & \text { period } & \\ h & \mathrm{hm} & \mathrm{ht} & \mathrm{bt} & \text { Dn50 } & \mathrm{Hs} & \mathrm{Tp} & \end{array}$
(m)
(m)
(m)
(m) $\quad\left(m^{\wedge} 3\right)$
(m)
(s)

$\begin{array}{lllllllll}\text { RELO804 } & 0.8 & 0.4 & 0.32 & 0.12 & 0.017 & 0.169 & 1.69 & 0.5 \\ \text { REL0804 } & 0.8 & 0.4 & 0.32 & 0.12 & 0.025 & 0.201 & 1.91 & 0.5 \\ \text { REL0804 } & 0.8 & 0.4 & 0.32 & 0.12 & 0.035 & 0.212 & 1.98 & 0.5 \\ \text { REL0804 } & 0.8 & 0.4 & 0.32 & 0.12 & 0.017 & 0.205 & 1.94 & 2 \\ \text { REL0804 } & 0.8 & 0.4 & 0.32 & 0.12 & 0.025 & 0.229 & 2.11 & 2 \\ \text { REL0804 } & 0.8 & 0.4 & 0.32 & 0.12 & 0.035 & 0.229 & 2.11 & 2 \\ \text { REL0804 } & 0.8 & 0.4 & 0.32 & 0.12 & 0.017 & 0.226 & 2.09 & 4 \\ \text { REL0804 } & 0.8 & 0.4 & 0.32 & 0.12 & 0.025 & - & & 4 \\ \text { REL0804 } & 0.8 & 0.4 & 0.32 & 0.12 & 0.035 & - & & 4 \\ & & & & & & & & \\ \text { REL0902 } & 0.9 & 0.5 & 0.42 & 0.12 & 0.017 & 0.187 & 2.3 & 0.5 \\ \text { REL0902 } & 0.9 & 0.5 & 0.42 & 0.12 & 0.025 & 0.187 & 2.3 & 0.5 \\ \text { REL0902 } & 0.9 & 0.5 & 0.42 & 0.12 & 0.035 & 0.239 & 2.74 & 0.5 \\ \text { REL0902 } & 0.9 & 0.5 & 0.42 & 0.12 & 0.017 & 0.262 & 2.92 & 2 \\ \text { REL0902 } & 0.9 & 0.5 & 0.42 & 0.12 & 0.025 & 0.262 & 2.92 & 2 \\ \text { REL0902 } & 0.9 & 0.5 & 0.42 & 0.12 & 0.035 & - & & 2 \\ \text { REL0902 } & 0.9 & 0.5 & 0.42 & 0.12 & 0.017 & - & & 4 \\ \text { REL0902 } & 0.9 & 0.5 & 0.42 & 0.12 & 0.025 & - & & 4 \\ \text { REL0902 } & 0.9 & 0.5 & 0.42 & 0.12 & 0.035 & - & & 4 \\ \text { REL0904 } & 0.9 & 0.5 & 0.42 & 0.12 & 0.017 & 0.172 & 1.66 & 0.5 \\ \text { REL0904 } & 0.9 & 0.5 & 0.42 & 0.12 & 0.025 & 0.172 & 1.66 & 0.5 \\ \text { REL0904 } & 0.9 & 0.5 & 0.42 & 0.12 & 0.035 & 0.235 & 2.02 & 0.5 \\ \text { REL0904 } & 0.9 & 0.5 & 0.42 & 0.12 & 0.017 & 0.258 & 1.99 & 2 \\ \text { REL0904 } & 0.9 & 0.5 & 0.42 & 0.12 & 0.025 & 0.258 & 1.99 & 2 \\ \text { REL0904 } & 0.9 & 0.5 & 0.42 & 0.12 & 0.035 & - & & 2 \\ \text { REL0904 } & 0.9 & 0.5 & 0.42 & 0.12 & 0.017 & - & & 4 \\ \text { REL0904 } & 0.9 & 0.5 & 0.42 & 0.12 & 0.025 & - & & 4 \\ \text { REL0904 } & 0.9 & 0.5 & 0.42 & 0.12 & 0.035 & - & & 4\end{array}$


Deep Shallow TOE TOE TOE SHALLOWWATER

Water Water Depth Width Armour Wave Wave Nod depth depth above to size height period

h hm ht bt Dn50 Hs Tp
(m)
(m)
(m)
(m) $\quad\left(m^{\wedge} 3\right)$
(m)
(s)

$\begin{array}{lllllrlll}\text { REH702 } & 0.7 & 0.3 & 0.15 & 0.12 & 0.025 & 0.136 & 2.08 & 0.5 \\ \text { REH702 } & 0.7 & 0.3 & 0.15 & 0.12 & 0.035 & 0.143 & 2.13 & 0.5 \\ \text { REH702 } & 0.7 & 0.3 & 0.15 & 0.12 & 0.04 & 0.155 & 2.22 & 0.5 \\ & & & & & & & & \\ \text { REH702 } & 0.7 & 0.3 & 0.15 & 0.12 & 0.025 & 0.146 & 2.16 & 2 \\ \text { REH702 } & 0.7 & 0.3 & 0.15 & 0.12 & 0.035 & 0.159 & 2.26 & 2 \\ \text { REH702 } & 0.7 & 0.3 & 0.15 & 0.12 & 0.04 & 0.173 & 2.45 & 2 \\ & & & & & & & & \\ \text { REH702 } & 0.7 & 0.3 & 0.15 & 0.12 & 0.025 & 0.158 & 2.25 & 4 \\ \text { REH702 } & 0.7 & 0.3 & 0.15 & 0.12 & 0.035 & 0.178 & 2.54 & 4 \\ \text { REH702 } & 0.7 & 0.3 & 0.15 & 0.12 & 0.04 & 0.194 & 2.88 & 4 \\ & & & & & & & & \\ \text { REH704 } & 0.7 & 0.3 & 0.15 & 0.12 & 0.025 & 0.136 & 1.53 & 0.5 \\ \text { REH704 } & 0.7 & 0.3 & 0.15 & 0.12 & 0.035 & 0.141 & 1.56 & 0.5 \\ \text { REH704 } & 0.7 & 0.3 & 0.15 & 0.12 & 0.04 & 0.141 & 1.56 & 0.5 \\ & & & & & & & & \\ \text { REH704 } & 0.7 & 0.3 & 0.15 & 0.12 & 0.025 & 0.145 & 1.57 & 2 \\ \text { REH704 } & 0.7 & 0.3 & 0.15 & 0.12 & 0.035 & 0.179 & 1.94 & 2 \\ \text { REH704 } & 0.7 & 0.3 & 0.15 & 0.12 & 0.04 & 0.161 & 1.73 & 2 \\ & & & & & & & & \\ \text { REH704 } & 0.7 & 0.3 & 0.15 & 0.12 & 0.025 & 0.156 & 1.68 & 4 \\ \text { REH704 } & 0.7 & 0.3 & 0.15 & 0.12 & 0.035 & 0.185 & 2.04 & 4 \\ \text { REH704 } & 0.7 & 0.3 & 0.15 & 0.12 & 0.04 & 0.196 & 2.2 & 4 \\ & & & & & & & & \\ \text { REH802 } & 0.8 & 0.4 & 0.25 & 0.12 & 0.025 & 0.149 & 2.09 & 0.5 \\ \text { REH802 } & 0.8 & 0.4 & 0.25 & 0.12 & 0.035 & - & & 0.5 \\ \text { REH802 } & 0.8 & 0.4 & 0.25 & 0.12 & 0.04 & 0.186 & 2.37 & 0.5 \\ & & & & & & & & \\ \text { REH802 } & 0.8 & 0.4 & 0.25 & 0.12 & 0.025 & 0.168 & 2.22 & 2 \\ \text { REH802 } & 0.8 & 0.4 & 0.25 & 0.12 & 0.035 & 0.227 & 2.97 & 2 \\ \text { REH802 } & 0.8 & 0.4 & 0.25 & 0.12 & 0.04 & - & & 2 \\ \text { REH802 } & 0.8 & 0.4 & 0.25 & 0.12 & 0.025 & 0.192 & 2.41 & 4 \\ \text { REH802 } & 0.8 & 0.4 & 0.25 & 0.12 & 0.035 & - & & 4 \\ \text { REH802 } & 0.8 & 0.4 & 0.25 & 0.12 & 0.04 & - & & 4\end{array}$




$\begin{array}{cccccccc}\text { Deep } & \text { Shallow } & \text { TOE } & \text { TOE } & \text { TOE } & \text { SHALLOW WATER } & \\ \text { Water } & \text { Water } & \text { Depth } & \text { Width } & \text { Armour } & \text { Wave } & \text { Wave } & \text { Nod } \\ \text { depth } & \text { depth above to } & & \text { size } & \text { height } & \text { period } & \\ h & \mathrm{hm} & \mathrm{ht} & \mathrm{bt} & \text { Dn50 } & \mathrm{Hs} & \mathrm{Tp} & \end{array}$
(m)
(m)
(m)
(m) $\quad\left(\mathrm{m}^{\wedge} 3\right)$
(m)
(s)

$\begin{array}{lllllllll}\text { REH804 } & 0.8 & 0.4 & 0.25 & 0.12 & 0.025 & - & & 0.5 \\ \text { REH804 } & 0.8 & 0.4 & 0.25 & 0.12 & 0.035 & - & & 0.5 \\ \text { REH804 } & 0.8 & 0.4 & 0.25 & 0.12 & 0.04 & 0.192 & 1.85 & 0.5 \\ & & & & & & & & \\ \text { REH804 } & 0.8 & 0.4 & 0.25 & 0.12 & 0.025 & 0.171 & 1.7 & 2 \\ \text { REH804 } & 0.8 & 0.4 & 0.25 & 0.12 & 0.035 & 0.212 & 1.98 & 2 \\ \text { REH804 } & 0.8 & 0.4 & 0.25 & 0.12 & 0.04 & 0.217 & 2.02 & 2 \\ & & & & & & & & \\ \text { REH804 } & 0.8 & 0.4 & 0.25 & 0.12 & 0.025 & 0.206 & 1.95 & 4 \\ \text { REH804 } & 0.8 & 0.4 & 0.25 & 0.12 & 0.035 & - & & 4 \\ \text { REH804 } & 0.8 & 0.4 & 0.25 & 0.12 & 0.04 & - & & 4 \\ \text { REH902 } & 0.9 & 0.5 & 0.35 & 0.12 & 0.025 & 0.154 & 2.04 & 0.5 \\ \text { REH902 } & 0.9 & 0.5 & 0.35 & 0.12 & 0.035 & 0.179 & 2.24 & 0.5 \\ \text { REH902 } & 0.9 & 0.5 & 0.35 & 0.12 & 0.04 & 0.236 & 2.71 & 0.5 \\ & & & & & & & & \\ \text { REH902 } & 0.9 & 0.5 & 0.35 & 0.12 & 0.025 & 0.178 & 2.22 & 2 \\ \text { REH902 } & 0.9 & 0.5 & 0.35 & 0.12 & 0.035 & 0.24 & 2.74 & 2 \\ \text { REH902 } & 0.9 & 0.5 & 0.35 & 0.12 & 0.04 & - & & 2 \\ \text { REH902 } & 0.9 & 0.5 & 0.35 & 0.12 & 0.025 & 0.213 & 2.51 & 4 \\ \text { REH902 } & 0.9 & 0.5 & 0.35 & 0.12 & 0.035 & - & & 4 \\ \text { REH902 } & 0.9 & 0.5 & 0.35 & 0.12 & 0.04 & - & & 4 \\ \text { REH904 } & 0.9 & 0.5 & 0.35 & 0.12 & 0.025 & 0.148 & 1.58 & 0.5 \\ \text { REH904 } & 0.9 & 0.5 & 0.35 & 0.12 & 0.035 & 0.211 & 1.86 & 0.5 \\ \text { REH904 } & 0.9 & 0.5 & 0.35 & 0.12 & 0.04 & 0.211 & 1.86 & 0.5 \\ \text { REH904 } & 0.9 & 0.5 & 0.35 & 0.12 & 0.025 & 0.189 & 1.73 & 2 \\ \text { REH904 } & 0.9 & 0.5 & 0.35 & 0.12 & 0.035 & 0.235 & 2.02 & 2 \\ \text { REH904 } & 0.9 & 0.5 & 0.35 & 0.12 & 0.04 & 0.238 & 2.04 & 2 \\ \text { REH904 } & 0.9 & 0.5 & 0.35 & 0.12 & 0.025 & 0.222 & 1.94 & 4 \\ \text { REH904 } & 0.9 & 0.5 & 0.35 & 0.12 & 0.035 & 0.247 & 2.12 & 4 \\ \text { REH904 } & 0.9 & 0.5 & 0.35 & 0.12 & 0.04 & 0.252 & 2.15 & 4\end{array}$




$\begin{array}{cccccccc}\text { Deep } & \text { Shallow } & \text { TOE } & \text { TOE } & \text { TOE } & \text { SHALLOW WATER } & \\ \text { Water } & \text { Water } & \text { Depth } & \text { Width } & \text { Armour } & \text { Wave } & \text { Wave } & \text { Nod } \\ \text { depth } & \text { depth } & \text { above to } & & \text { size } & \text { height } & \text { period } & \\ \text { h } & \mathrm{hm} & \mathrm{ht} & \mathrm{bt} & \mathrm{Dn} 50 & \mathrm{Hs} & \mathrm{Tp} & \end{array}$

\begin{tabular}{lcccccccr} 
& $(m)$ & $(m)$ & $(m)$ & \multicolumn{1}{c}{$(\mathrm{m})$} & $\left(\mathrm{m}^{\wedge} 3\right)$ & \multicolumn{1}{l}{$(\mathrm{m})$} & \multicolumn{1}{l}{$(\mathrm{s})$} & \\
RHH802 & 0.8 & 0.4 & 0.18 & 0.12 & 0.025 & 0.132 & 1.97 & 0.5 \\
RHH802 & 0.8 & 0.4 & 0.18 & 0.12 & 0.035 & 0.138 & 2 & 0.5 \\
RHH802 & 0.8 & 0.4 & 0.18 & 0.12 & 0.04 & 0.173 & 2.26 & 0.5 \\
& & & & & & & & \\
RHH802 & 0.8 & 0.4 & 0.18 & 0.12 & 0.025 & 0.148 & 2.09 & 2 \\
RHH802 & 0.8 & 0.4 & 0.18 & 0.12 & 0.035 & 0.177 & 2.29 & 2 \\
RHH802 & 0.8 & 0.4 & 0.18 & 0.12 & 0.04 & 0.209 & 2.58 & 2 \\
& & & & & & & & \\
RHH802 & 0.8 & 0.4 & 0.18 & 0.12 & 0.025 & 0.167 & 2.21 & 4 \\
RHH802 & 0.8 & 0.4 & 0.18 & 0.12 & 0.035 & 0.216 & 2.66 & 4 \\
RHH802 & 0.8 & 0.4 & 0.18 & 0.12 & 0.04 & 0.244 & 3.04 & 4 \\
& & & & & & & & \\
RHH804 & 0.8 & 0.4 & 0.18 & 0.12 & 0.025 & 0.117 & 1.3 & 0.5 \\
RHH804 & 0.8 & 0.4 & 0.18 & 0.12 & 0.035 & 0.137 & 1.45 & 0.5 \\
RHH804 & 0.8 & 0.4 & 0.18 & 0.12 & 0.04 & 0.163 & 1.64 & 0.5 \\
& & & & & & & & \\
RHH804 & 0.8 & 0.4 & 0.18 & 0.12 & 0.025 & 0.149 & 1.53 & 2 \\
RHH804 & 0.8 & 0.4 & 0.18 & 0.12 & 0.035 & 0.182 & 1.64 & 2 \\
RHH804 & 0.8 & 0.4 & 0.18 & 0.12 & 0.04 & 0.219 & 2.04 & 2 \\
& & & & & & & - & \\
RHH804 & 0.8 & 0.4 & 0.18 & 0.12 & 0.025 & 0.174 & 1.72 & 4 \\
RHH804 & 0.8 & 0.4 & 0.18 & 0.12 & 0.035 & 0.225 & 2.08 & 4 \\
RHH804 & 0.8 & 0.4 & 0.18 & 0.12 & 0.04 & - & & 4 \\
& & & & & & & & \\
RHH902 & 0.9 & 0.5 & 0.28 & 0.12 & 0.025 & 0.14 & 1.92 & 0.5 \\
RHH902 & 0.9 & 0.5 & 0.28 & 0.12 & 0.035 & 0.173 & 2.2 & 0.5 \\
RHH902 & 0.9 & 0.5 & 0.28 & 0.12 & 0.04 & 0.173 & 2.2 & 0.5 \\
RHH902 & 0.9 & 0.5 & 0.28 & 0.12 & 0.025 & 0.172 & 2.2 & 2 \\
RHH902 & 0.9 & 0.5 & 0.28 & 0.12 & 0.035 & 0.226 & 2.62 & 2 \\
RHH902 & 0.9 & 0.5 & 0.28 & 0.12 & 0.04 & 0.235 & 2.7 & 2 \\
RHH902 & 0.9 & 0.5 & 0.28 & 0.12 & 0.025 & 0.206 & 2.46 & 4 \\
RHH902 & 0.9 & 0.5 & 0.28 & 0.12 & 0.035 & - & & 4 \\
RHH902 & 0.9 & 0.5 & 0.28 & 0.12 & 0.04 & - & & 4
\end{tabular}


Deep Shallow TOE TOE TOE SHALLOWWATER

Water Water Depth Width Armour Wave Wave Nod

depth depth above to size height period

$\mathrm{h} h \mathrm{hm}$ ht bt Dn50 Hs Tp

$(m) \quad(m) \quad(m) \quad(m) \quad\left(m^{\wedge} 3\right) \quad(m) \quad(s)$

$\begin{array}{lllllllll}\text { RHH904 } & 0.9 & 0.5 & 0.28 & 0.12 & 0.025 & 0.153 & 1.6 & 0.5 \\ \text { RHH904 } & 0.9 & 0.5 & 0.28 & 0.12 & 0.035 & 0.165 & 1.63 & 0.5 \\ \text { RHH904 } & 0.9 & 0.5 & 0.28 & 0.12 & 0.04 & 0.186 & 1.72 & 0.5 \\ & & & & & & & & \\ \text { RHH904 } & 0.9 & 0.5 & 0.28 & 0.12 & 0.025 & 0.177 & 1.68 & 2 \\ \text { RHH904 } & 0.9 & 0.5 & 0.28 & 0.12 & 0.035 & 0.226 & 1.96 & 2 \\ \text { RHH904 } & 0.9 & 0.5 & 0.28 & 0.12 & 0.04 & 0.247 & 2.12 & 2 \\ & & & & & & & & \\ \text { RHH904 } & 0.9 & 0.5 & 0.28 & 0.12 & 0.025 & 0.205 & 1.82 & 4 \\ \text { RHH904 } & 0.9 & 0.5 & 0.28 & 0.12 & 0.035 & - & & 4 \\ \text { RHH904 } & 0.9 & 0.5 & 0.28 & 0.12 & 0.04 & - & & 4 \\ \text { REB902 } & 0.9 & 0.5 & 0.35 & 0.2 & 0.025 & 0.154 & 2.04 & 0.5 \\ \text { REB902 } & 0.9 & 0.5 & 0.35 & 0.2 & 0.035 & 0.159 & 2.08 & 0.5 \\ \text { REB902 } & 0.9 & 0.5 & 0.35 & 0.2 & 0.04 & 0.192 & 2.34 & 0.5 \\ \text { REB902 } & 0.9 & 0.5 & 0.35 & 0.2 & 0.025 & 0.175 & 2.21 & 2 \\ \text { REB902 } & 0.9 & 0.5 & 0.35 & 0.2 & 0.035 & 0.217 & 2.55 & 2 \\ \text { REB902 } & 0.9 & 0.5 & 0.35 & 0.2 & 0.04 & 0.234 & 2.68 & 2 \\ \text { REB902 } & 0.9 & 0.5 & 0.35 & 0.2 & 0.025 & 0.219 & 2.57 & 4 \\ \text { REB902 } & 0.9 & 0.5 & 0.35 & 0.2 & 0.035 & 0.261 & 2.91 & 4 \\ \text { REB902 } & 0.9 & 0.5 & 0.35 & 0.2 & 0.04 & 0.261 & 2.91 & 4 \\ \text { REB904 } & 0.9 & 0.5 & 0.35 & 0.2 & 0.025 & 0.166 & 1.64 & 0.5 \\ \text { REB904 } & 0.9 & 0.5 & 0.35 & 0.2 & 0.035 & 0.192 & 1.75 & 0.5 \\ \text { REB904 } & 0.9 & 0.5 & 0.35 & 0.2 & 0.04 & 0.214 & 1.88 & 0.5 \\ \text { REB904 } & 0.9 & 0.5 & 0.35 & 0.2 & 0.025 & 0.202 & 1.82 & 2 \\ \text { REB904 } & 0.9 & 0.5 & 0.35 & 0.2 & 0.035 & 0.252 & 2.15 & 2 \\ \text { REB904 } & 0.9 & 0.5 & 0.35 & 0.2 & 0.04 & 0.237 & 2.04 & 2 \\ \text { REB904 } & 0.9 & 0.5 & 0.35 & 0.2 & 0.025 & 0.225 & 1.97 & 4 \\ \text { REB904 } & 0.9 & 0.5 & 0.35 & 0.2 & 0.035 & - & & 4 \\ \text { REB94 } & 0.9 & 0.5 & 0.35 & 0.2 & 0.04 & 0.252 & 2.15 & 4\end{array}$




$\begin{array}{cccccccc}\text { Deep } & \text { Shallow } & \text { TOE } & \text { TOE } & \text { TOE } & \text { SHALLOW WATER } & \\ \text { Water } & \text { Water } & \text { Depth } & \text { Width } & \text { Armour } & \text { Wave } & \text { Wave } & \text { Nod } \\ \text { depth } & \text { depth above to } & & \text { size } & \text { height period } & \\ \text { h } & \mathrm{hm} & \mathrm{ht} & \mathrm{bt} & \text { Dn50 } & \mathrm{Hs} & \mathrm{Tp}\end{array}$

\begin{tabular}{|c|c|c|c|c|c|c|c|c|}
\hline & (m) & (m) & (m) & (m) & $\left(m^{n} \wedge\right)$ & (m) & (s) & \\
\hline RBB902 & 0.9 & 0.5 & 0.35 & 0.3 & 0.025 & 0.132 & 1.86 & 0.5 \\
\hline RBB902 & 0.9 & 0.5 & 0.35 & 0.3 & 0.035 & 0.176 & 2.21 & 0.5 \\
\hline RBB902 & 0.9 & 0.5 & 0.35 & 0.3 & 0.04 & 0.225 & 2.61 & 0.5 \\
\hline RBB902 & 0.9 & 0.5 & 0.35 & 0.3 & 0.025 & 0.166 & 2.13 & 2 \\
\hline RBB902 & 0.9 & 0.5 & 0.35 & 0.3 & 0.035 & 0.23 & 2.66 & 2 \\
\hline $\mathrm{ABB} 902$ & 0.9 & 0.5 & 0.35 & 0.3 & 0.04 & 0.257 & 2.88 & 2 \\
\hline RBB902 & 0.9 & 0.5 & 0.35 & 0.3 & 0.025 & 0.197 & 2.38 & 4 \\
\hline RBB902 & 0.9 & 0.5 & 0.35 & 0.3 & 0.035 & 0.254 & 2.86 & 4 \\
\hline ABB902 & 0.9 & 0.5 & 0.35 & 0.3 & 0.04 & - & & 4 \\
\hline RBB904 & 0.9 & 0.5 & 0.35 & 0.3 & 0.025 & 0.159 & 1.6 & 0.5 \\
\hline RBB904 & 0.9 & 0.5 & 0.35 & 0.3 & 0.035 & 0.194 & 1.76 & 0.5 \\
\hline RBB904 & 0.9 & 0.5 & 0.35 & 0.3 & 0.04 & 0.25 & 2.15 & 0.5 \\
\hline RBB904 & 0.9 & 0.5 & 0.35 & 0.3 & 0.025 & 0.188 & 1.73 & 2 \\
\hline RBB904 & 0.9 & 0.5 & 0.35 & 0.3 & 0.035 & 0.261 & 2.24 & 2 \\
\hline ABB904 & 0.9 & 0.5 & 0.35 & 0.3 & 0.04 & - & & 2 \\
\hline ABB904 & 0.9 & 0.5 & 0.35 & 0.3 & 0.025 & 0.204 & 1.82 & 4 \\
\hline RBB904 & 0.9 & 0.5 & 0.35 & 0.3 & 0.035 & - & & 4 \\
\hline RBB904 & 0.9 & 0.5 & 0.35 & 0.3 & 0.04 & - & & 4 \\
\hline
\end{tabular}




\begin{tabular}{|c|c|c|c|c|c|c|c|c|c|c|}
\hline $\begin{array}{c}\text { Test } \\
\text { series } \\
\text { No }\end{array}$ & $\begin{array}{c}\text { Test } \\
\text { No }\end{array}$ & $\begin{array}{c}\text { Deep } \\
\text { Water } \\
\text { depth } \\
\text { h } \\
(m)\end{array}$ & $\begin{array}{c}\text { Shallo } \\
\text { Water } \\
\text { depth } \\
\mathrm{hm} \\
\text { (m) }\end{array}$ & $\begin{array}{l}\text { TOE } \\
\text { Depth } \\
\text { above toe } \\
\text { ht } \\
\text { (m) }\end{array}$ & $\begin{array}{l}\text { TOE } \\
\text { Nidth } \\
\text { be } \\
(\mathrm{m})\end{array}$ & $\begin{array}{c}\text { TOE } \\
\text { Armour } \\
\text { size } \\
\text { Dn50 } \\
\text { m }\end{array}$ & $\begin{array}{l}\text { WATER } \\
\text { Wave } \\
\text { height } \\
\text { Hs } \\
\text { (m) }\end{array}$ & $\begin{array}{c}\text { WATER } \\
\text { Wave } \\
\text { height } \\
\text { Hs } \\
\text { (m) }\end{array}$ & DAMA & DAMA \\
\hline 1 & 1.5 & 23.3 & 11.3 & 7.8 & 5 & 1.147 & 7.46 & 7.31 & 6.1 & 0.99 \\
\hline 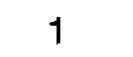 & $2-2$ & 20.3 & 8.3 & 4.8 & 5 & 1.147 & 3.49 & 3.73 & 0.17 & 0.03 \\
\hline 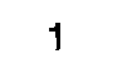 & $2-3$ & 20.3 & 8.3 & 4.8 & 5 & 1.147 & 4.86 & 4.96 & 0.85 & 0.14 \\
\hline 1 & $2-4$ & 20.3 & 8.3 & 4.8 & 5 & 1.147 & 5.3 & 5.3 & 1.53 & 0.25 \\
\hline 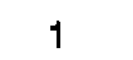 & $2-5$ & 20.3 & 8.3 & 4.8 & 5 & 1.147 & 6.27 & 6 & 4.58 & 0.74 \\
\hline 1 & $4-1$ & 23.3 & 11.3 & 7.8 & 5 & 1.147 & 2.8 & 2.9 & 0.17 & 0.03 \\
\hline 1 & $4-2$ & 23.3 & 11.3 & 7.8 & 5 & 1.147 & 3.69 & 3.87 & 0.34 & 0.06 \\
\hline 1 & $4-3$ & 23.3 & 11.3 & 7.8 & 5 & 1.147 & 4.92 & 5.17 & 0.85 & 0.14 \\
\hline 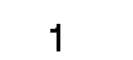 & $4-4$ & 23.3 & 11.3 & 7.8 & 5 & 1.147 & 5.38 & 5.63 & 1.02 & 0.16 \\
\hline 1 & $4-5$ & 23.3 & 11.3 & 7.8 & 5 & 1.147 & 6.82 & 7.04 & 4.59 & 0.74 \\
\hline 1 & $4-6$ & 23.3 & 11.3 & 7.8 & 5 & 1.147 & 8.37 & 8.14 & 13.77 & 2.22 \\
\hline 1 & $5-1$ & 29.2 & 16.3 & 10.3 & 7.5 & 1.147 & 3.7 & 3.7 & 0.53 & 0.05 \\
\hline 1. & $5-2$ & 29.2 & 16.3 & 10.3 & 7.5 & 1.147 & 4.97 & 5.03 & 4.23 & 0.42 \\
\hline 1 & $5-3$ & 29.2 & 16.3 & 10.3 & 7.5 & 1.147 & 5.77 & 5.9 & 3.7 & 0.32 \\
\hline 1 & $5-4$ & 29.2 & 16.3 & 10.3 & 7.5 & 1.147 & 7.86 & 8.13 & 6.08 & 0.61 \\
\hline 1 & $5-5$ & 29.2 & 16.3 & 10.3 & 7.5 & 1.147 & 9.01 & 9.34 & 27.8 & 2.76 \\
\hline 1 & $6-1$ & 26.2 & 13.3 & 7.3 & 7.5 & 1.147 & 4.29 & 4.4 & 2.12 & 0.21 \\
\hline 1 & $6-2$ & 26.2 & 13.3 & 73 & 7.5 & 1.147 & 4.24 & 4.35 & 3.44 & 0.34 \\
\hline 1 & $6-3$ & 26.2 & 13.3 & 7.3 & 7.5 & 1.147 & 5.16 & 5.38 & 3.7 & 0.37 \\
\hline 1 & $6-4$ & 26.2 & 13.3 & 7.3 & 7.6 & 1.147 & 6.64 & 7.03 & 3.7 & 0.37 \\
\hline 1 & $6-5$ & 26.2 & 13.3 & 7.3 & 7.5 & 1.147 & 8.78 & 8.87 & 39.95 & 3.97 \\
\hline 1 & $7-1$ & 29.2 & 16.3 & 10.3 & 7.5 & 1.147 & 3.61 & 3.62 & 1.06 & 0.11 \\
\hline 1 & $7-2$ & 29.2 & 16.3 & 10.3 & 7.5 & 1.147 & 4.54 & 4.58 & 3.18 & 0.32 \\
\hline 1 & $7-3$ & 29.2 & 16.3 & 10.3 & 7.5 & 1.147 & 5.81 & 5.95 & 4.5 & 0.45 \\
\hline 1 & $7-4$ & 29.2 & .16 .3 & 10.3 & 7.5 & 1.147 & 6.6 & 6.92 & 8.2 & 0.82 \\
\hline 1 & $7-5$ & 29.2 & 16.3 & 10.3 & 7.5 & 1.147 & 8.72 & 9.1 & 29.1 & 2.89 \\
\hline$<$ & $1 \mathrm{~A}$ & 42.8 & 16.2 & 9 & 4 & 1.321 & - & 4.75 & 1.7 & 0.26 \\
\hline 2 & $1 \mathrm{~B}$ & 42.8 & 16.2 & 9 & 4 & 1.321 & 6.89 & 6.65 & 3.5 & 0.54 \\
\hline 2 & $1 C$ & 42.8 & 16.2 & 9 & 4 & 1.321 & 7.8 & 7.5 & 3.5 & 0.54 \\
\hline 2 & 10 & 428 & 16.2 & 9 & 4 & 1.321 & 9.03 & 8.3 & 3.5 & 0.54 \\
\hline 2 & $2 A$ & 42.8 & 16.2 & 9 & 4 & 1.321 & 4.97 & 4.75 & 1 & 0.15 \\
\hline 2 & $2 \mathrm{~B}$ & 42.8 & 16.2 & 9 & 4 & 1.321 & 6.91 & 6.65 & 1.9 & 0.29 \\
\hline 2 & $2 C$ & 42.8 & 16.2 & 9 & 4. & 1.321 & 8.07 & 7.7 & 2.5 & 0.38 \\
\hline
\end{tabular}




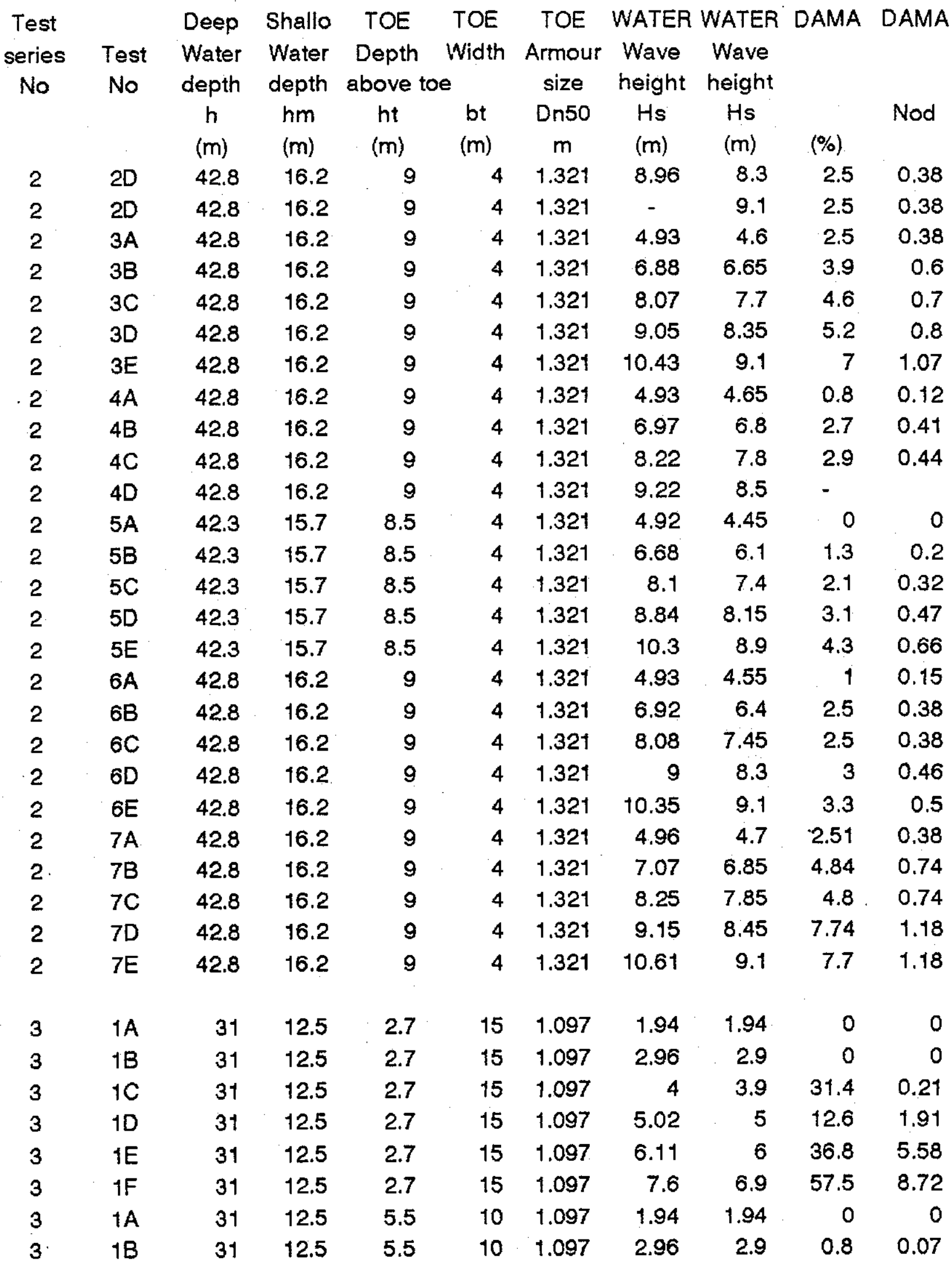




\begin{tabular}{|c|c|c|c|c|c|c|c|c|c|c|}
\hline $\begin{array}{c}\text { Test } \\
\text { series } \\
\text { No }\end{array}$ & $\begin{array}{l}\text { Test } \\
\text { No }\end{array}$ & $\begin{array}{l}\text { Deep } \\
\text { Water } \\
\text { depth } \\
\text { h } \\
(m)\end{array}$ & $\begin{array}{c}\text { Shallo } \\
\text { Water } \\
\text { depth } \\
\mathrm{hm} \\
\text { (m) }\end{array}$ & $\begin{array}{l}\text { TOE } \\
\text { Depth } \\
\text { above toe } \\
\text { ht } \\
\text { (m) }\end{array}$ & $\begin{array}{l}\text { TOE } \\
\text { Width } \\
e^{\text {bt }} \\
(\mathrm{m})\end{array}$ & $\begin{array}{c}\text { TOE } \\
\text { Armour } \\
\text { size } \\
\text { Dn50 } \\
\text { m }\end{array}$ & $\begin{array}{c}\text { WATER } \\
\text { Wave } \\
\text { height } \\
\text { Hs } \\
(\mathrm{m})\end{array}$ & $\begin{array}{l}\text { WATER } \\
\text { Wave } \\
\text { height } \\
\text { Hs } \\
\text { (m) }\end{array}$ & DAMA & DAMA \\
\hline 3 & $1 \mathrm{C}$ & 31 & 12.5 & 5.5 & 10 & 1.097 & 4 & 3.9 & 5 & 0.45 \\
\hline 3 & 10 & 31 & 12.5 & 5.5 & 10 & 1.097 & 5.02 & 5 & 5.8 & 0.53 \\
\hline 3 & $1 E$ & 31 & 12.5 & 5.5 & 10 & 1.097 & 6.11 & 6 & - & \\
\hline 3 & $1 F$ & 31 & 12.5 & 5.5 & 10 & 1.097 & 7.6 & 6.9 & 43.8 & 3.97 \\
\hline 3 & $2 A$ & 31.6 & 13.1 & 3.3 & 15 & 1.097 & 3.03 & 2.9 & 0 & 0 \\
\hline . & $2 B$ & 31.6 & 13.1 & 3.3 & 15 & 1.097 & 4 & 3.95 & 1.1 & 0.17 \\
\hline 3 & $2 \mathrm{C}$ & 31.6 & 13.1 & 3.3 & 15 & 1.097 & 4.94 & 4.9 & 10.8 & 1.69 \\
\hline 3 & $2 D$ & 31.6 & 13.1 & 3.3 & 15 & 1.097 & 6.08 & 6 & 50 & 7.58 \\
\hline 3 & $2 E$ & 31.6 & 13.1 & 3.3 & 15 & 1.097 & 7.6 & 6.9 & 50 & 7.58 \\
\hline 3 & $2 A$ & 31.6 & 13.1 & 6.1 & 10 & 1.097 & 3.03 & 2.9 & 0.8 & 0.07 \\
\hline 3 & $2 B$ & 31.6 & 13.1 & 6.1 & 10 & 1.097 & 4 & 3.95 & 1.5 & 0.14 \\
\hline 3 & $2 C$ & 31.6 & 13.1 & 6.1 & 10 & 1.097 & 4.94 & 4.9 & 9.2 & 0.83 \\
\hline 3 & $2 \mathrm{D}$ & 31.6 & 13.1 & 6.1 & 10 & 1.097 & 6.08 & 6 & 50 & 4.52 \\
\hline 3 & $2 \mathrm{E}$ & 31.6 & 13.1 & 6.1 & 10 & 1.097 & 7.6 & 6.9 & 53.8 & 4.87 \\
\hline 3 & $4 C$ & 31.6 & 13.1 & 6.1 & 15.67 & 1.097 & 3.07 & 3 & 0 & 0 \\
\hline 3 & $4 D$ & 31.6 & 13.1 & 6.1 & 15.67 & 1.097 & 4.07 & 4 & 1.8 & 0.38 \\
\hline 3 & $4 \mathrm{E}$ & 31.6 & 13.1 & 6.1 & 15.67 & 1.097 & 5.09 & 5.05 & 12 & 2.8 \\
\hline 3 & $4 F$ & 31.6 & 13.1 & 6.1 & 15.67 & 1.097 & 6.21 & 6.15 & 52.2 & 12.7 \\
\hline 3 & $4 G$ & 31.6 & 13.1 & 6.1 & 15.67 & 1.097 & 7.6 & 6.9 & 52.2 & 12.7 \\
\hline 3 & $5 A$ & 31.6 & 13.1 & 3.3 & 15 & 1.097 & 3.44 & 3.4 & 0 & 0 \\
\hline 3 & $5 B$ & 31.6 & 13.1 & 3.3 & 15 & 1.097 & 4.54 & 4.5 & 9.2 & 1.5 \\
\hline 3 & $5 C$ & 31.6 & 13.1 & 3.3 & 15 & 1.097 & 5.63 & 5.55 & 17.8 & 2.9 \\
\hline 3 & $5 D$ & 31.6 & 13.1 & 3.3 & 15 & 1.097 & 6.97 & 6.75 & 31.4 & 5.11 \\
\hline 3 & $5 E$ & 31.6 & 13.1 & 3.3 & 15 & 1.097 & 7.6 & 6.9 & - & \\
\hline 3 & $5 A$ & 31.6 & 13.1 & 6.1 & 10 & 1.097 & 3.44 & 3.4 & 1.3 & 0.35 \\
\hline 3 & $5 B$ & 31.6 & 13.1 & 6.1 & 10 & 1.097 & 4.54 & 4.5 & 3.9 & 1.04 \\
\hline 3 & $5 C$ & 31.6 & 13.1 & 6.1 & 10 & 1.097 & 5.63 & 5.55 & 13 & 3.48 \\
\hline 3 & 50 & 31.6 & 13.1 & 6.1 & 10 & 1.097 & 6.97 & 6.75 & - & \\
\hline 3 & $5 E$ & 31.6 & 13.1 & 6.1 & 10 & 1.097 & 7.6 & 6.9 & - & \\
\hline 3 & $6 \mathrm{C}$ & 31.6 & 13.1 & 6.1 & 15.67 & 1.097 & 3.49 & 3.45 & 0 & 0 \\
\hline 3 & $6 \mathrm{D}$ & 31.6 & 13.1 & 6.1 & 15.67 & 1.097 & 4.6 & 4.55 & 0.6 & 0.17 \\
\hline 3 & $6 \mathrm{E}$ & 31.6 & 13.1 & 6.1 & 15.67 & 1.097 & 5.74 & 5.7 & 5.6 & 1.56 \\
\hline 3 & $6 F$ & 31.6 & 13.1 & 6.1 & 15.67 & 1.097 & 7 & 6.75 & 12.4 & 3.46 \\
\hline 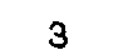 & $G$ & 31.6 & 13.1 & 6.1 & 15.67 & 1.097 & 7.6 & 6.9 & 14.8 & 4.13 \\
\hline
\end{tabular}




\begin{tabular}{|c|c|c|c|c|c|c|c|c|c|c|}
\hline $\begin{array}{c}\text { Test } \\
\text { series } \\
\text { No }\end{array}$ & $\begin{array}{l}\text { Test } \\
\text { No }\end{array}$ & $\begin{array}{c}\text { Deep } \\
\text { Water } \\
\text { depth } \\
h \\
(\mathrm{~m})\end{array}$ & $\begin{array}{c}\text { Shallo } \\
\text { Water } \\
\text { depth } \\
\mathrm{hm} \\
(\mathrm{m})\end{array}$ & $\begin{array}{l}\text { TOE } \\
\text { Depth } \\
\text { above toe } \\
\text { ht } \\
\text { (m) }\end{array}$ & $\begin{array}{l}\text { TOE } \\
\text { Width } \\
\text { bt } \\
(\mathrm{m})\end{array}$ & $\begin{array}{c}\text { TOE } \\
\text { Armour } \\
\text { size } \\
\text { Dn50 } \\
m\end{array}$ & $\begin{array}{c}\text { WATER } \\
\text { Wave } \\
\text { height } \\
\text { Hs } \\
\text { (m) }\end{array}$ & $\begin{array}{c}\text { WATER } \\
\text { Wave } \\
\text { height } \\
\text { Hs } \\
\text { (m) }\end{array}$ & DAMA & DAMA \\
\hline 4 & $11 \mathrm{~A}$ & 21 & 13 & 7.5 & 3 & 0.862 & 3.95 & 3.90 & 1.00 & 0.12 \\
\hline 4 & $11 B$ & 21 & 13 & 7.5 & 3 & 0.862 & 4.63 & 4.63 & 1.50 & 0.17 \\
\hline 4 & $11 C$ & 21 & 13 & 7.5 & 3 & 0.862 & 5.81 & 5.37 & 2.50 & 0.29 \\
\hline 4 & 110 & 21 & 13 & 7.5 & 3 & 0.862 & 6.58 & 5.68 & 2.50 & 0.29 \\
\hline 4 & $12 A$ & 21 & 13 & 7.5 & 3 & 0.862 & 3.65 & 3.63 & 0.80 & 0.09 \\
\hline 4 & $12 B$ & 21 & 13 & 7.5 & 3 & 0.862 & 4.14 & 4.24 & 2.00 & 0.23 \\
\hline 4 & $12 \mathrm{C}$ & 21 & 13 & 7.5 & 3 & 0.862 & 5.21 & 5.34 & 5.00 & 0.58 \\
\hline 4 & $12 D$ & 21 & 13 & 7.5 & 3 & 0.862 & 5.98 & 5.98 & 7.50 & 0.87 \\
\hline 4 & $21 \mathrm{~A}$ & 20 & 12 & 6.5 & 3 & 0.862 & 3.76 & 3.77 & 0.80 & 0.09 \\
\hline 4 & $21 B$ & 20 & 12 & 6.5 & 3 & 0.862 & 4.88 & 4.65 & 2.80 & 0.32 \\
\hline 4 & $21 C$ & 20 & 12 & 6.5 & 3 & 0.862 & 5.72 & 5.05 & 3.30 & 0.38 \\
\hline 4 & 210 & 20 & 12 & 6.5 & 3 & 0.862 & 6.43 & 5.27 & 3.30 & 0.38 \\
\hline 4 & $22 \mathrm{~A}$ & 20 & 12 & 6.5 & 3 & 0.862 & 3.45 & 3.48 & 1.30 & 0.14 \\
\hline 4 & $22 \mathrm{~B}$ & 20 & 12 & 6.5 & 3 & 0.862 & 4.34 & 4.45 & 4.50 & 0.52 \\
\hline 4 & $22 \mathrm{C}$ & 20 & 12 & 6.5 & 3 & 0.862 & 5.16 & 5.21 & 7.50 & 0.87 \\
\hline 4 & $22 D$ & 20 & 12 & 6.5 & 3 & 0.862 & 5.91 & 5.82 & 15.00 & 1.74 \\
\hline 4 & $31 \mathrm{~A}$ & 20 & 12 & 4.5 & 3 & 0.862 & 3.95 & 3.94 & 6.80 & 0.78 \\
\hline 4 & $31 \mathrm{~B}$ & 20 & 12 & 4.5 & 3 & 0.862 & 4.91 & 4.81 & 13.00 & 1.56 \\
\hline 4 & $31 C$ & 20 & 12 & 4.5 & 3 & 0.862 & 5.78 & 5.04 & 18.30 & 2.12 \\
\hline 4 & $31 D$ & 20 & 12 & 4.5 & 3 & 0.862 & 6.51 & 5.28 & 22.50 & 2.7 \\
\hline 4 & $32 \mathrm{~A}$ & 20 & 12 & 4.5 & 3 & 0.862 & 3.46 & 3.49 & 6.00 & 0.7 \\
\hline 4 & $32 \mathrm{~B}$ & 20 & 12 & 4.5 & 3 & 0.862 & 4.37 & 4.48 & 15.00 & 1.74 \\
\hline 4 & $32 \mathrm{C}$ & 20 & 12 & 4.5 & 3 & 0.862 & 5.22 & 5.25 & 23.80 & 2.75 \\
\hline 4 & $32 \mathrm{D}$ & 20 & 12 & 4.5 & 3 & 0.862 & 6.00 & 5.87 & 40.00 & 2.9 \\
\hline 4 & $42 \mathrm{~A}$ & 21 & 13 & 7.5 & 3 & 0.862 & 3.53 & 3.52 & 0.50 & 0.03 \\
\hline 4 & $42 B$ & 21 & 13 & 7.5 & 3 & 0.862 & 4.14 & 4.24 & 2.50 & 0.15 \\
\hline 4 & $42 \mathrm{C}$ & 21 & 13 & 7.5 & 3 & 0.862 & 5.15 & 5.26 & 6.00 & 0.35 \\
\hline 4 & $42 D$ & 21 & 13 & 7.5 & 3 & 0.862 & 6.04 & 6.01 & 11.00 & 0.64 \\
\hline 4 & $51 \mathrm{~A}$ & 20 & 12 & 6.5 & 3 & 0.862 & 3.87 & 3.85 & 1.30 & 0.14 \\
\hline 4 & $51 B$ & 20 & 12 & 6.5 & 3 & 0.862 & 4.90 & 4.65 & 3.80 & 0.43 \\
\hline 4 & $51 C$ & 20 & 12 & 6.5 & 3 & 0.862 & 5.80 & 5.08 & 4.50 & 0.52 \\
\hline 4 & $51 \mathrm{D}$ & 20 & 12 & 6.5 & 3 & 0.862 & 6.51 & 5.35 & 4.50 & 0.52 \\
\hline 4 & $52 \mathrm{~A}$ & 20 & 12 & 6.5 & 3 & 0.862 & 3.52 & 4.09 & 2.50 & 0.14 \\
\hline 4 & $52 B$ & 20 & 12 & 6.5 & 3 & 0.862 & 4.34 & 5.49 & 2.50 & 0.14 \\
\hline 4 & $52 \mathrm{C}$ & 20 & 12 & 6.5 & 3 & 0.862 & 5.26 & 6.78 & 4.50 & 0.52 \\
\hline
\end{tabular}


Test series No

Deep Shallo TOE TOE TOE WATER WATER DAMA DAMA Test Water Water Depth Width Armour Wave Wave No depth depth above toe size height height

$\mathrm{h} h \mathrm{hm}$ ht bt Dn50 Hs Hs

$$
\begin{array}{llllllll}
(\mathrm{m}) & (\mathrm{m}) & (\mathrm{m}) & (\mathrm{m}) & \mathrm{m} & (\mathrm{m}) & (\mathrm{m}) & (\%)
\end{array}
$$

$\begin{array}{rcccccccccr}4 & 52 \mathrm{D} & 20 & 12 & 6.5 & 3 & 0.862 & 6.09 & 7.53 & 9.00 & 1.04 \\ 4 & 61 \mathrm{~A} & 21 & 13 & 7.5 & 3 & 0.862 & 3.25 & 3.24 & 1.30 & 0 \\ 4 & 61 \mathrm{~B} & 21 & 13 & 7.5 & 3 & 0.862 & 4.75 & 4.69 & 3.80 & 0 \\ 4 & 61 \mathrm{C} & 21 & 13 & 7.5 & 3 & 0.862 & 5.89 & 5.33 & 4.50 & 0.43 \\ 4 & 61 \mathrm{D} & 21 & 13 & 7.5 & 3 & 0.862 & 6.80 & 5.65 & 4.50 & 0.58 \\ 4 & 62 \mathrm{~A} & 21 & 13 & 7.5 & 3 & 0.862 & 2.97 & 2.92 & 2.50 & 0 \\ 4 & 62 \mathrm{~B} & 21 & 13 & 7.5 & 3 & 0.862 & 4.17 & 4.27 & 2.50 & 0 \\ 4 & 62 \mathrm{C} & 21 & 13 & 7.5 & 3 & 0.862 & 5.16 & 5.26 & 4.50 & 0.17 \\ 4 & 62 \mathrm{D} & 21 & 13 & 7.5 & 3 & 0.862 & 6.04 & 6.02 & 9.00 & 0.26 \\ 4 & 71 \mathrm{~A} & 20 & 12 & 6.5 & 3 & 0.862 & 3.92 & 3.91 & 0.00 & 0 \\ 4 & 71 \mathrm{~B} & 20 & 12 & 6.5 & 3 & 0.862 & 4.77 & 4.58 & 0.00 & 0 \\ 4 & 71 \mathrm{C} & 20 & 12 & 6.5 & 3 & 0.862 & 5.95 & 5.15 & 1.30 & 0.14 \\ 4 & 71 \mathrm{D} & 20 & 12 & 6.5 & 3 & 0.862 & 6.83 & 5.31 & 2.50 & 0.29 \\ 4 & 72 \mathrm{~A} & 20 & 12 & 6.5 & 3 & 0.862 & 3.55 & 3.55 & 0.00 & 0 \\ 4 & 72 \mathrm{~B} & 20 & 12 & 6.5 & 3 & 0.862 & 4.03 & 4.15 & 0.00 & 0 \\ 4 & 72 \mathrm{C} & 20 & 12 & 6.5 & 3 & 0.862 & 5.23 & 5.26 & 4.00 & 0.23 \\ 4 & 72 \mathrm{D} & 20 & 12 & 6.5 & 3 & 0.862 & 6.13 & 5.90 & 6.00 & 0.35 \\ 4 & 81 \mathrm{~A} & 21 & 13 & 7.5 & 3 & 0.862 & 4.08 & 4.04 & 0.00 & 0 \\ 4 & 81 \mathrm{~B} & 21 & 13 & 7.5 & 3 & 0.862 & 4.72 & 4.69 & 1.50 & 0.17 \\ 4 & 81 \mathrm{~B} 2 & 21 & 13 & 7.5 & 3 & 0.862 & 4.72 & 4.69 & 1.50 & 0.17 \\ 4 & 81 \mathrm{C} & 21 & 13 & 7.5 & 3 & 0.862 & 5.93 & 5.34 & 1.80 & 0.2 \\ 4 & 81 \mathrm{C} 2 & 21 & 13 & 7.5 & 3 & 0.862 & 5.93 & 5.34 & 2.30 & 0.26 \\ 4 & 81 \mathrm{D} & 21 & 13 & 7.5 & 3 & 0.862 & 6.85 & 5.65 & 3.30 & 0.38 \\ 4 & 81 \mathrm{D} 2 & 21 & 13 & 7.5 & 3 & 0.862 & 6.85 & 5.65 & 4.00 & 0.46 \\ 4 & 82 \mathrm{~A} & 21 & 13 & 7.5 & 3 & 0.862 & 3.66 & 3.65 & 0.00 & 0 \\ 4 & 82 \mathrm{~B} & 21 & 13 & 7.5 & 3 & 0.862 & 4.18 & 4.28 & 5.00 & 0.29 \\ 4 & 82 \mathrm{~B} 2 & 21 & 13 & 7.5 & 3 & 0.862 & 4.18 & 4.28 & 5.00 & 0.29 \\ 4 & 82 \mathrm{C} & 21 & 13 & 7.5 & 3 & 0.862 & 5.23 & 5.32 & 8.50 & 0.49 \\ 4 & 82 \mathrm{C} 2 & 21 & 13 & 7.5 & 3 & 0.862 & 5.23 & 5.32 & 12.00 & 0.7 \\ 4 & 82 \mathrm{D} & 21 & 13 & 7.5 & 3 & 0.862 & 6.11 & 6.05 & 17.00 & 0.99 \\ 4 & 82 \mathrm{D} 2 & 21 & 13 & 7.5 & 3 & 0.862 & 6.11 & 6.05 & 17.00 & 0.99 \\ & & & & & & & & & & \\ 5 & 1 \mathrm{~A} & 57 & 49 & 23.85 & 15 & 3.265 & 5.54 & 5.37 & 0.00 & 0 \\ 5 & 1 \mathrm{~B} & 57 & 49 & 23.85 & 15 & 3.265 & 5.54 & 5.37 & 0.00 & 0 \\ 5 & 1 \mathrm{C} & 57 & 49 & 23.85 & 15 & 3.265 & 5.54 & 5.37 & 0.00 & 0\end{array}$




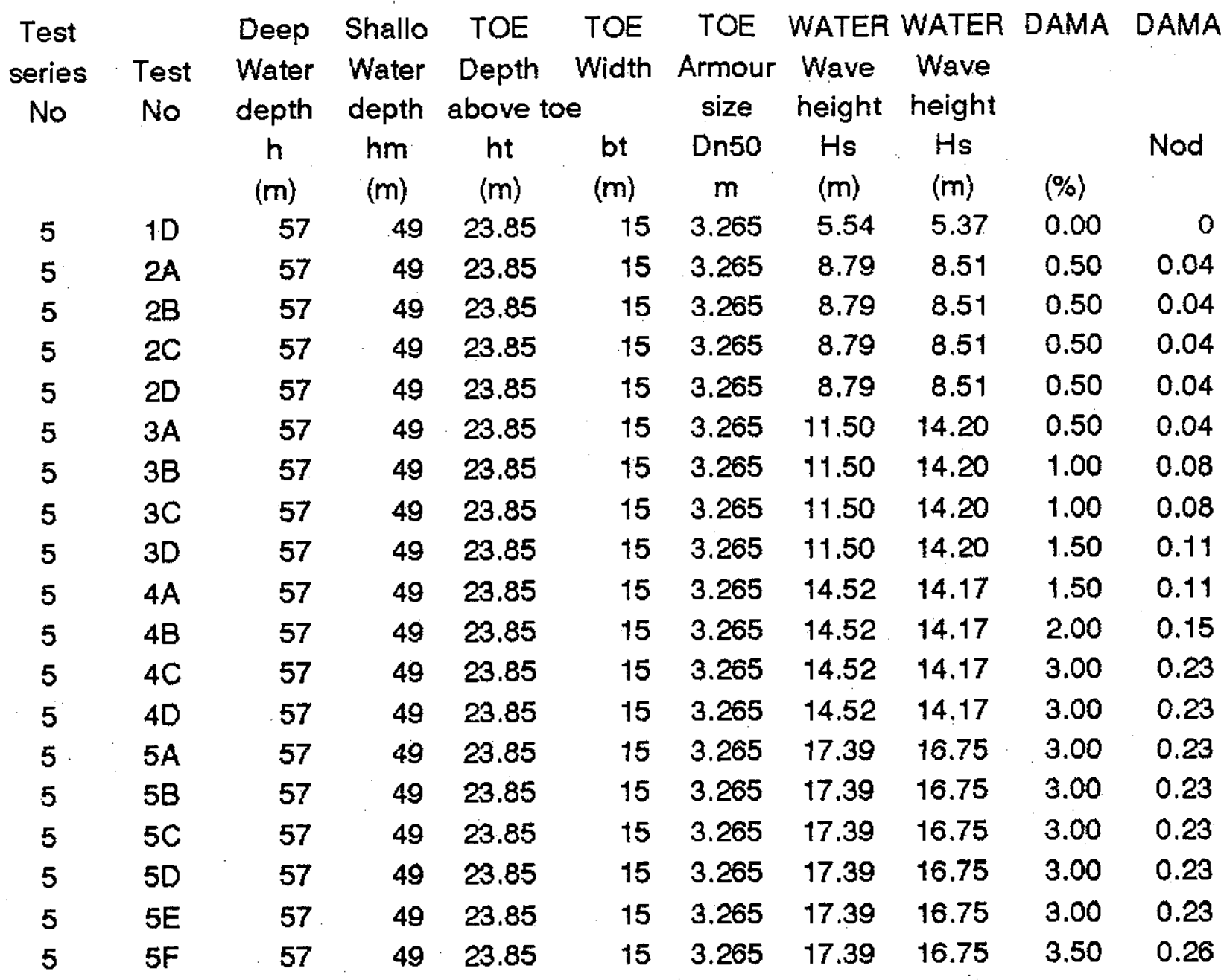

